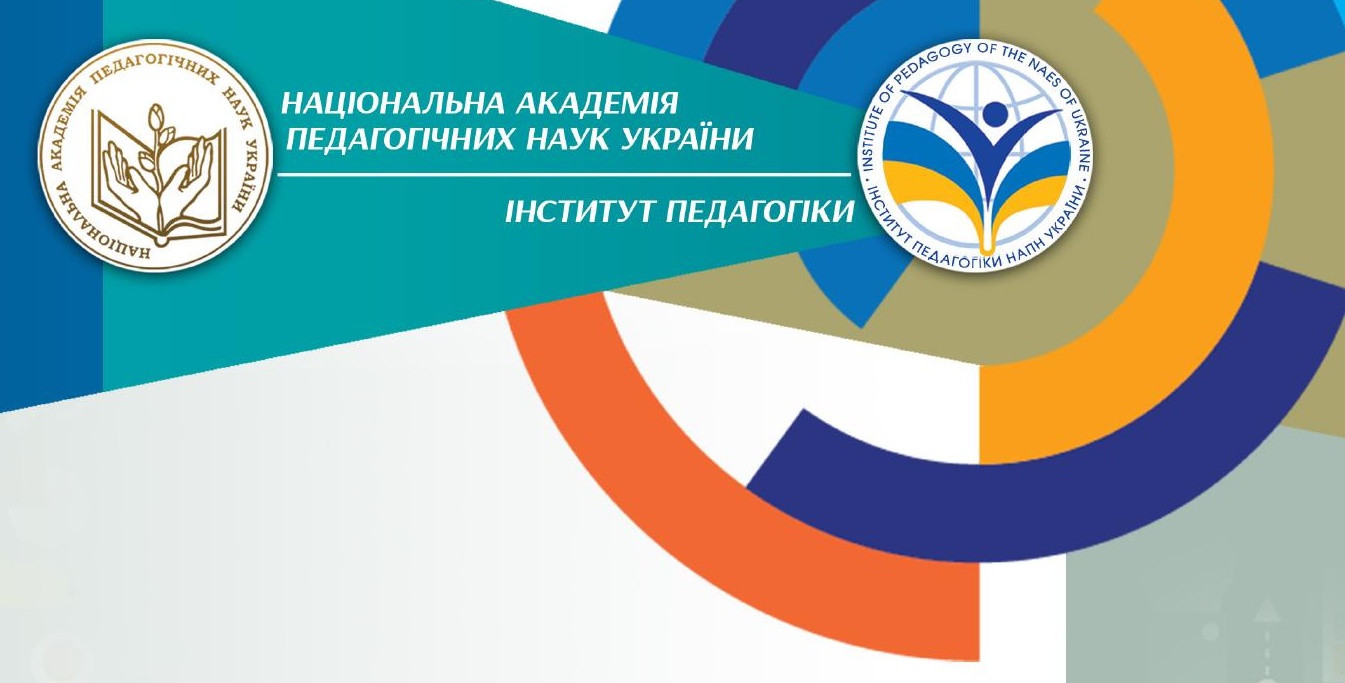

ДИСТАНЦЙНЕ НАВЧАННЯ B YMOBAX KAPAHTИHY: ДОСВ|Д ТА ПЕРСПЕКТИВИ

Аналітико-метоgичні матеріали

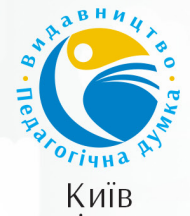

Педагогічна думка 2021 
УДК 373.091.33-024.87:614.46"4"

Д48

Рекомендовано до друку вченою радою

Інституту педагогіки НАПН України

(протокол №7 від 18 червня 2021 р.).

\section{Рецензенти:}

Л.М. Калініна, доктор педагогічних наук, професор;

T.M. Засєкіна, кандидат педагогічних наук, старший науковий співробітник.

\section{За загальною редакцією дійсного члена НАПН України, д.пед.н., проф. О.М. Топузова.}

\section{Авторський колектив:}

Н.І. Богданець-Білоскаленко (4.1.3), Н.В. Бондаренко (4.1.1), М.І. Бурда (4.4), Д.В. Васильєва (4.4.), Л.П. Величко (4.3.1), С.Г. Головко (6.1), О.В. Голота (1.3), О.М. Горошкіна (4.1.1), Т.М. Засєкіна, В.Р. Ільченко (1.3), О.Г. Козленко (4.3.1), Т.В. Коршевнюк (4.3.1), І.П. Крячко (4.3.2), О.І. Локшина (р. 2), Т.О. Лукіна (5.1, 5.3), О.В. Малихін (1.1), Т.Г. Назаренко (4.4), С.О. Науменко (5.2), О.С. Нетрибійчук(4.3.1), В.І. Новосьолова (4.1.1), О.М. Онаць (6.2), О.В. Онопрієнко (р. 3), Т.К. Полонська (4.1.4), О.І. Пометун (4.2.), Л.О. Попова (4.1.1), В.Г. Редько (4.1.4), Т.О. Ремех (4.2), В.В. Сіпій (4.3.2), С.Е. Трубачева (1.2), В.І. Туташинський (4.5), О.Л. Фідкевич (4.1.3), О.М. Шпарик (р.2), Т.О. Яценко (4.1.2).

Упорядник М.В. Головко.

\section{Д48}

Дистанційне навчання в умовах карантину: досвід та перспективи. Аналітико-методичні матеріали /кол. автор. ; за загальною редакцією О.М. Топузова ; укл. М.В. Головко. Київ : Педагогічна думка, 2021. - 192 с. DOI : http://doi.org/10.32405/978-966-644-596-7-2021-192

ISBN 978-966-644-596-7

У виданні представлено аналітико-методичні матеріали підготовлені співробітниками Інституту педагогіки НАПН України, що висвітлюють досвід організації дистанційного навчання в закладах загальної середньої освіти в умовах карантинних обмежень та перспективні напрями його розвитку. Матеріали адресовані керівникам та педагогічним працівникам закладів освіти.

Удк 373.091.33-024.87:614.46"4"

(C) Інститут педагогіки НАПН України, 2021

(C) Педагогічна думка, 2021 


\section{MICT}

ВСТУП

\section{РОЗДІЛ 1. ДИСТАНЦІЙНЕ НАВЧАННЯ}

В УМОВАХ ГЛОБАЛЬНИХ ВИКЛИКІВ

1.1. Дистанційне навчання як педагогічна технологія . . . . . . . .6

1.2. Проєктування освітнього середовища закладу загальної середньої освіти з урахуванням особливостей дистанційного та змішаного навчання . . . . 18

1.3. Роль дистанційного навчання в досягнені мети державного стандарту загальної середньої освіти . . . . . . .26

\section{РОЗДІЛ 2. ОСОБЛИВОСТІ ДИСТАНЦІЙНОГО}

НАВЧАННЯ В ЗАРУБІЖЖІ .

\section{РОЗДІЛ З. ОРГАНІЗАЦІЯ ДИСТАНЦІЙНОГО НАВЧАННЯ}

У ПОЧАТКОВІЙ ШКОЛІ

\section{РОЗДІЛ 4. ОРГАНІЗАЦІЯ ДИСТАНЦІЙНОГО НАВЧАННЯ}

В ЗАКЛАДАХ СЕРЕДНЬОЇ ОСВІТИ ІІ ТА ІІІ СТУПЕНІВ

4.1. Особливості організації дистанційного навчання предметів мовно-літературної галузі. . . . . . . . . 50

4.1.1. Особливості дистанційного навчання української мови ......................50

4.1.2. Особливості дистанційного навчання української літератури...................58

4.1.3 Особливості дистанційного навчання української мови в школах з навчанням мовами національних меншин . . . . . . . . . . . . . .66

4.1.4. Особливості дистанційного навчання іноземних мов . . . . . . . . . . . . . . . 72

4.2. Методична підтримка вчителів історії, основ правознавства та громадянської освіти в умовах дистанційного навчання . . . . . . . . . . . . .77

4.3. Особливості дистанційного навчання природничих предметів.

4.3.1. Особливості дистанційного навчання біології і хімії . . . . 84 
4.3.2. Особливості дистанційного навчання фізики та астрономії ....................94

4.3.3. Особливості дистанційного навчання географії . . . . .102

4.4. Особливості дистанційного навчання математики . . . . . . .109

4.5. Особливості дистанційного навчання інформатики . . . . . .131

4.6. Особливості дистанційного навчання предметів технологічної галузі . . . . . . . . . . . . . . . . . . . . 137

\section{РОЗДІЛ 5. ОЦІНЮВАННЯ НАВЧАЛЬНИХ ДОСЯГНЕНЬ}

\section{ЗДОБУВАЧІВ загальНої середньої ОСВІТИ}

В УМОВАХ ДИСТАНЦІЙНОГО НАВЧАННЯ

5.1. Особливості оцінювання результатів навчальної діяльності в дистанційній формі. . . . . . . . . . . . . . . . . 144

5.2. Реалізація сертифікаційного оцінювання здобувачів загальної середньої освіти в умовах пандемії COVID-19 . . . . . . . . . . . . . . 156

5.3. Можливості та проблеми реалізації підсумкового оцінювання навчальних результатів в дистанційній формі. ....................161

РОЗДІЛ 6. ОРГАНІЗАЦІЙНО-ПРАВОВІ АСПЕКТИ ФУНКЦІОНУВАННЯ ЗАКЛАДІВ ЗАГАЛЬНОЇ СЕРЕДНЬОЇ ОСВІТИ ТА УПРАВЛІННЯ НИМИ В УМОВАХ ДИСТАНЦІЙНОГО НАВЧАННЯ ..............167

6.1. Організаційно-правові засади реалізації дистанційного навчання в закладах загальної середньої освіти

6.2. Особливості управлінської діяльності керівника закладу освіти в умовах дистанційного навчання . . . . . . . . . . . . . 170

ЗАГАЛЬНІ ВИСНОВКИ ТА РЕКОМЕНДАЦІї ............178

ВИКОРИСТАНІ ДЖЕРЕЛА ...................... 181 


\section{ВСТУП}

Освіта стала однією з галузей, що зазнали найбільш глобальних впливів в умовах застосування жорстких карантинних обмежень, спрямованих на протидію поширення коронавірусної інфекції. За даними ЮНЕСКО, майже у 200 країнах вимушено залишилися вдома понад 1,5 мільярда учнів і студентів (а це майже 91\% світового населення, яке навчається). Станом на травень 2020 року, коли частина країн почала поступово виходити з тотального карантину, неохопленими навчанням у закладах освіти залишалося $67,7 \%$ дітей та молоді світу (150 країн так і не відкрили шкіл до кінця навчального року) [114].

Кардинальні зміни в організації освітнього процесу вплинули не лише на його суб'єктів, а й на батьків, працівників підприємств і установ, що безпосередньо чи опосередковано забезпечують функціонування освітньої галузі. Перед суспільством постали нові виклики, зумовлені необхідністю оптимізувати функціонування освіти в нових умовах. Запровадження карантину, спричиненого глобальною пандемією COVID-19, спонукало системи освіти багатьох країн світу перейти на дистанційне навчання, яке виявилося досить серйозним випробуванням для учасників освітнього процесу по всьому світу, зокрема і в Україні.

Якщо українські заклади вищої освіти й раніше практикували дистанційну форму навчання, то для закладів загальної середньої освіти організація віддалених занять виявилася справжнім викликом. Зокрема, 57\% закладів уперше зіткнулися з використанням технологій дистанційного навчання в освітньому процесі. На початковому етапі його запровадження $41 \%$ педагогів просто надсилали учням завдання та вправи для самостійного опрацювання. I лише $18 \%$ учителів проводили уроки онлайн. Найскладнішим, на думку $72 \%$ керівників шкіл, у процесі реалізації дистанційного навчання під час пандемії стало налагодження зв'язку з учнями [13].

Водночас упродовж 2020-2021 навчального року дистанційне навчання утвердилося як одна з достатньо ефективних технологій у системі загальної середньої освіти, що дає можливість підтримувати доступну та якісну освіту в умовах карантинних обмежень. Українськими педагогами та науковцями напрацьовано значний досвід організації дистанційного навчання та його науково-методичного супроводу.

У цьому збірнику аналітико-методичних матеріалів представлено результати аналізу стану та перспектив подальшого розвитку дистанційного навчання в системі загальної середньої освіти, а також напрацювання фахівців Інституту педагогіки НАПН України щодо його наукового й методичного супроводу. 


\section{РОЗДІЛ 1}

\section{ДИСТАНЦІЙНЕ НАВЧАННЯ В УМОВАХ ГЛОБАЛЬНИХ ВИКЛИКІВ}

\section{1. ДИСТАНЦІЙНЕ НАВЧАННЯ ЯК ПЕДАГОГІЧНА ТЕХНОЛОГІЯ}

У Концепції розвитку дистанційної освіти в Україні ще в 2000 році було зазначено про необхідність забезпечення розвитку освіти на основі нових прогресивних концепцій, запровадження в навчально-виховний процес новітніх педагогічних технологій і науково-методичних досягнень, створення нової системи інформаційного забезпечення освіти. Планувалося, що поступове введення дистанційного навчання сприятиме появі нових можливостей для оновлення змісту навчання та методів викладання дисциплін і розповсюдження знань; розширення доступу до всіх рівнів освіти; реалізації системи безперервної освіти протягом життя; індивідуалізації навчання за масовості освіти. Дистанційна освіта трактувалася як рівноцінна форма навчання, що реалізується за технологіями дистанційного навчання. Педагогічні технології дистанційного навчання визначалися як технології опосередкованого активного спілкування з використанням телекомунікаційного зв'язку та методології індивідуальної роботи зі структурованим навчальним матеріалом, представленим в електронному вигляді. Соціальними групами було визначено досить широкий загал суспільства, в тому числі - учні шкіл. На дистанційне навчання могли зараховуватися учні з високими навчальними досягненнями [29].

Але практики масового переходу в світовому масштабі до дистанційного чи змішаного навчання ще не існує. Цей виклик сучасності в умовах пандемії торкається всього контингенту учнів (віком з 6-7 до 16-18 років). Саме цим спричинено появу зовсім нових проблем психологічного та педагогічного (чи суто дидактичного) характеру. Нині нові документи про дистанційне (змішане) навчання регламентують цю форму навчання як повноправну форму, за якої може забезпечуватися повна загальна середня освіта. Виникає необхідність оновлення спектру існуючих форм і методів навчання, їхньої адаптації до умов дистанційного навчання. 
Прописується необхідність створювати умови для забезпечення повноцінної участі всіх учасників освітнього процесу, у тому числі - із особливими освітніми потребами. Батьки мають перетворитися на суб'єктів дистанційного навчання (разом із учнями та педагогічними працівниками) і надзвичайно важливе значення має їхнє сприяння виконанню дитячої освітньої програми та досягненню дитиною певних результатів навчання. Прописано важливість організації зворотного зв'язку та конструктивної комунікації між усіма учасниками освітнього процесу [103].

Основним сучасним трендом розвитку освіти $€$ впровадження цифрових технологій і перехід до он-лайн-освіти. У зв'язку з цим з'явилася нова галузь педагогічного знання, яка ще не має усталеної назви. I тому в публікаціях різних авторів вживають поняття: е-дидактика, електронна педагогіка, електронне навчання, комп'ютерна система навчання, дистанційне навчання тощо.

Педагоги трактують ці поняття наступним чином:

- “комп'ютерна дидактика - частина дидактики, що займається проблемами процесів навчання, темою вивчення яких $€$ комп'ютер і його застосування, і ця тема вивчається таким чином, що той, хто навчається, має можливість самостійної роботи на комп'ютері» [117];

- «Е-дидактика - це сукупність знань, процесів і стратегій, орієнтована на гарантоване формування в процесі дистанційного навчання в учнів таких компетенцій, які б відповідали конкретно заданим рівням їх освоєння» [111];

- «E-didactics - галузь сучасної дидактики, що досліджує закони, закономірності, принципи й засоби електронного навчання, що застосовуються з метою дистанційного здобуття компетенцій» [98].

У межах цієї галузі знання вчені досліджують низку проблем:

1. Становлення й розвиток теоретичної бази, у тому числі понятійного апарату.

2. Види й методики проведення електронних занять, у тому числі дистанційні лабораторні практикуми.

3. Дидактичні властивості інструментів (програмних засобів і сервісів Інтернету).

4. Форми подання навчальних матеріалів для вивчення в електронному інформаційно-освітньому середовищі.

5. Підготовка педагогів для ефективного викладання в умовах електронного навчання.

6. Валеологія електронного навчання та Інтернет-безпека.

7. Виховні проблеми, які актуалізуються під час широкого використання Інтернету. 
8. Забезпечення якості е-навчання та його оцінювання.

9. Нормативно-правове забезпечення е-навчання.

10. Дослідження організаційних форм навчання, пошуку оптимального їх поєднання й ваги в змішаному й дистанційному варіантах здійснення навчального процесу.

11. Використання психолого-фізіологічного потенціалу людини (резервів людського мозку та психіки).

Глобальні виклики в суспільстві, що змінили світ, закономірно вплинули на пріоритети розвитку шкільної освіти та дали поштовх до розвитку й трансформації педагогічних технологій і моделей навчання. У достатньо екстремальних умовах розпочинається інформатизація навчання в масовому масштабі.

Основними вимогами для ефективного впровадження дистанційного навчання визначаються такі:

- створення якісно нового інформаційного освітнього середовища;

- трансформація й адаптація педагогічних технологій навчання до інформаційної взаємодії між суб'єктами навчання (учителем та учнями);

- оновлення навчально-методичного забезпечення освітнього процесу;

- забезпечення якісного моніторингу темпів просування кожного учня (на шляху опанування освітньої програми в дистанційному форматі);

- константне підвищення рівня інформаційної компетентності учнів і вчителів.

Усвідомлення наявних недоліків і проблем у реалізації дистанційного (змішаного навчання) для учнів різних вікових категорій - перший крок до створення дієвої системи освіти, здатної подолати сучасні непередбачувані проблеми.

1. Усвідомлення впливу гіперінформаційної епохи на особистість та психічне здоров'я учнів кожної вікової категорії.

Сучасну людину вражає інформаційне ожиріння. Зараз настала гіперінформаційна епоха: щоденно людство звертається до Google 105000000000 разів. 3 точки зору інформаційного споживання ми залежимо від особливостей нашого мозку, який споживає до $20 \%$ отриманої нами енергії. Тож за інформаційного "ожиріння» мозок надає пріоритет більш простій інформації: із двох видів інформації (наукова та розважальна) мозок обере другу. Учні протягом великого відрізку часу знаходяться в розважальному контенті (соцмережі, блогерство, ігровий сегмент). Іншими словами, фактично ми перемі- 
щуємося з «галактики Гутенберга» до «галактики Цукерберга». Мозок, який має розвивати нейронну сітку в природному середовищі розвиває її в інформаційній мережі. Наразі нейронні сітки в умовах гіперінформаційного навантаження призводять до того, що система, яка відповідає за мислення блокується. У такому середовищі відбувається втрата навичок соціальної взаємодії, необхідних для правильної роботи мозку. Відбувається втрата можливості людини формувати образ майбутнього (дистальне бачення).

2. Усвідомлення змін креативності учнів і їхніх можливостей фрормувати образ майбутнього в гіперінформаційну епоху.

Аналіз оцінок дітей за 50 років за класичним тестом креативності мислення Е. Торренса (дослідження Кюнг Хі Кім) 300000 дітей (динаміка креативності): до 80-х рр. креативність дітей зростала; до 90-х років вона була стабільною; 90-ті роки - почала знижуватися. Дослідження показало, що біля 40 \% дітей до 10 років та 60 \% підлітків постійно знаходяться он-лайн. Діти виключаються з зовнішнього середовища й не мають реального спілкування в достатньому обсязі. ґаджети стали фактично бебісітерами наших дітей: 54 \% дітей у віці 4-6 років та 97 \% в 11-14 років мають власний смартфон чи планшет, а 85 \% не можуть обійтися без нього. 92 \% батьків використовують планшет чи смартфон для розвитку 4-6 річної дитини, 32 \% мають конфлікти з дітьми через їхнє он-лайн-життя. 43 \% учнів початкової школи та 95 \% старшокласників мають сторінки в соцмережах. Тобто формувати вектор власного розвитку для цифрової людини - це завдання, що виходить за рамки його стандартних можливостей. Великий відсоток учнів намагаються обрати майбутньою професією саме ті, котрі пов'язані з комп'ютерним світом.

3. Виявлення психологічних проблем учнів в умовах дистанційного (змішаного) навчання.

Дослідження шкільних психологів виявили такі проблеми:

А) Виявлено причини шкільної дезадаптації (5-ті класи):

- низький рівень розвитку загальних розумових здібностей;

- високий ступінь емоційної нестійкості;

- несформованість мотиваційної сфери;

- високий рівень вимог на тлі низьких можливостей;

- характерологічні особливості;

- незрілість психіки, початок пубертатного періоду;

- особливості сімейного виховання;

- стиль керівництва педагогів. 
Б) Вимірювання та корекція рівня тривожності учнів (за параметрами):

- загальна тривожність;

- тривога в стосунках із однокласниками;

- тривога, пов'язана з оцінкою оточуючих;

- тривога в стосунках із учителями;

- тривога в стосунках із батьками;

- тривога, пов'язана з успіхами в навчанні;

- тривога, що виникає в ситуаціях самовираження;

- тривога, що виникає в ситуаціях перевірки знань;

- зниження психічної активності, зумовлене тривогою;

- підвищена вегетативна реактивність, зумовлена тривогою.

Результати показали наступне: між реакціями дівчаток і хлопчиків на певні ситуації $\epsilon$ відмінність. Хлопчики більше реагують на ситуації, пов'язані зі стосунками з однокласниками (11,55 \% у порівняні 3 $8,88 \%)$, з успіхами в навчанні $(14,63 \%-4,44 \%)$. Дівчаток більше, ніж хлопчиків, хвилюють проблеми самовираження $(41,07$ \% у порівнянні з 3,85 \%), вони більше схильні до вегетативних реакцій на подразники (37,74 \% - 13 \%). Дівчатка в такому віці більше схильні до підвищення важливості свого місця в навколишньому середовищі, вони прагнуть до самовираження через різні речі: бажання бути гарною, популярною в середовищі ровесників, подобатися хлопцям; прагнення до самоствердження й самовдосконалення; бажання досягти вищого рейтингу в колективі, отримати схвалення значущої людини (чи групи людей). Такі мотиви дуже впливають на психологічний стан дівчинки, на рівень її навчальних досягнень (який також може залежати від превалюючого мотиву). Поряд із цим важливими для дівчаток $€$ їхні навчальні досягнення: як частина ії загального рейтингу, як вимога суспільних впливів, учителів, батьків тощо. Як результат (і як вікові особливості, результат нестабільної ще психіки, початку пубертатного періоду) - підвищена вегетативна реактивність організму дівчаток. Тому впливати на певні сфери тривожності дитини потрібно вкрай обережно, бо дівчатка раніше починають розвиватися, ніж хлопчики, і лабільність психічних процесів у них набагато вища. Хлопчики на початку підліткового віку схильні до підвищення важливості стосунків із однолітками, особливо однокласниками. Досягнення вищого рейтингу в такому оточенні їм також притаманна, але мотиви тут трохи інші: превалюють мотиви сили, упевненості, лідерські якості. Разом із тим, хлопчики через невпевненість у своїх навчальних можливостях, відчувають тривогу на уроках, під час опитувань, що 
також викликає вегетативні реакції. Різниця в початку періодів пубертатного розвитку хлопчиків і дівчаток багато в чому впливає на їхній стиль поведінки й як результат - суттєво змінює систему впливів.

В) Дослідження психологічних проблем, що виникли в умовах пандемії та запровадження дистанційного (змішаного) навчання.

Дослідження психологічних проблем тривають, але потребують узагальнення та рекомендацій для вчителів і батьків. Стан «цифрового аутизму», який виникає в дітей в гіперінформаційну епоху, виявляється як:

- постійна перевірка соціальних мереж (навіть під час живого спілкування);

- розвиток емоційної глухоти;

- збідненість реального життя;

- легка заміна людей, з якими спілкуєшся в реальному житті;

- втрата толерантності в живому спілкуванні;

- спілкування в месенджерах стає більш привабливим і комфортним;

- час, проведений у соціальних мережах, домінує над реальним спілкуванням.

Звідси випливають проблеми суспільства в умовах цифровізації:

- зниження якості інтелектуальної діяльності;

- зниження якості освіти;

- зниження рівня емоційного інтелекту, зростання цифрової залежності, цифровий аутизм;

- зниження мотивації, відсутність толерантності в ситуації неуспіху.

У дитини під час цифрового навчання вчитель втрачає реальний авторитет, через що виникає блокування потужної сили для її мотивації до навчання. Шляхи опору «цифровому аутизму»: усвідомленість; цифрова гігієна; ефективна соціальність.

Отже, як результат, виникає потреба створення прогресивних педагогічних технологій, що зможуть забезпечити навчальний процес в умовах дистанційного (змішаного навчання).

1. Створення ефективного «трикутника партнерства»: учні-вчителі-батьки.

В умовах всесвітнього карантину та введення дистанційного навчання нового звучання набуває співпраця вчителя, учня й батьків. Така система вже давно практикується у вальдорфських школах. Вихователі, педагоги спілкуються з батьками як із суб'єктами освітнього процесу. На відміну від більшості державних традиційних освітніх закладів, тут батькам пропонують відвідати уроки, концерти, демонструють творчі роботи учнів. Цим вальдорфский процес навчан- 
ня викликає прихильність до себе тих батьків, які хочуть бути його активними учасниками. Батьки та їхні ініціативи завжди вітаються: допомога у виготовленні іграшок, оформленні та прибиранні групи, активна участь у святах та ін. Цю практику підтримують і творчі колективи, які вимушені закритися на період карантину, але не полишають активне спілкування та спільну роботу з вихованцями. Творчі роботи, танцювальні та музичні заняття, художні майстерні, перегляди й обговорення фільмів і постановок та багато чого іншого $€$ в їхньому арсеналі.

У який спосіб змінюється освітній процес у традиційних школах зараз. Дистанційне навчання для дітей різного віку зумовлює різний ступінь залучення до цього процесу батьків. Традиційно таке залучення обмежується спонуканням батьками дітей до активного навчання, забезпеченням контролю за виконанням уроків, але дуже рідко батькам пропонується стати учасниками процесу. Серед форм співпраці учнів, учителів і батьків можуть бути такі:

- організація робочого часу, засобів навчання та синхронізація зусиль;

- пасивна участь батьків під час взаємодії учня та вчителя за взаємною згодою (для тих учнів, які потребують допомоги чи індивідуальної роботи); відмова від такої участі під час взаємодії учня й класу (групи);

- можливість індивідуальних (чи за участі батьків) відеоконсультацій за потреби;

- графік взаємодії: проведення раз на тиждень класних годин, віртуальних консультацій, обговорень за участю батьків (в ефірі вчитель, слово учням та батькам за потреби з ключових питань, основне спілкування в чаті);

- спілкування батьків і вчителів про успішність учнів за домовленістю;

- налагодження постійної співпраці учнів між собою за дистанційної форми, завдання для всіх, проєкти та творчі роботи (робота в спільному документі, груповому чаті), презентація результатів такої співпраці для вчителів і батьків на відеоконференції;

- створення індивідуальної освітньої та виховної траєкторії учня з залученням до взаємодії батьків, регулярна комунікація;

- зворотний зв'язок: постійний чат, із якого виокремлюються актуальні питання та проблеми, винесення їх на обговорення.

Досить багато вчителів-практиків мають власні форми роботи з батьками, у тому числі - адаптовані до умов карантину. Така взаємодія про- 
писана в оновлених документах про дистанційну освіту, але ще немає прописаних методичних рекомендацій із такої форми взаємодії. На узагальню вальному рівні плюси й мінуси (переваги й недоліки) дистанційної освіти представлено в таблиці 1.1.

Таблиця 1.1

\section{Дистанційна освіта: плюси й мінуси (переваги й недоліки)}

\begin{tabular}{|c|c|c|}
\hline $\begin{array}{c}\text { Суб'єкт } \\
\text { освіт- } \\
\text { нього } \\
\text { процесу }\end{array}$ & Позитив & Негатив \\
\hline Учні & $\begin{array}{l}\text { Зменшення } \\
\text { фізичного } \\
\text { навантаження } \\
\text { (діти можуть } \\
\text { встати, поруха- } \\
\text { тись, закрити } \\
\text { очі), } 6 \text { уроків у } \\
\text { школі важче, } \\
\text { ніж } 6 \text { уроків } \\
\text { вдома. } \\
\text { Відсутність ри- } \\
\text { зику зараження } \\
\text { інфекційними } \\
\text { хворобами, } \\
\text { а значить - } \\
\text { більше мож- } \\
\text { ливостей для } \\
\text { збереження } \\
\text { здоров'я. } \\
\text { Пізнання діть- } \\
\text { ми комп'ютера } \\
\text { як користувачів } \\
\text { підвищилося. } \\
\text { З'явилася мож- } \\
\text { ливість відтер- } \\
\text { мінувати здачу } \\
\text { обов'язкових } \\
\text { видів робіт } \\
\text { (контрольних і } \\
\text { самостійних). }\end{array}$ & $\begin{array}{l}\text { Погіршення зору через тривале користування } \\
\text { комп'ютером. } \\
\text { Частина дітей хитрує й обманює учителів, якщо } \\
\text { немає бажання вчитися, якісно засвоювати знання } \\
\text { й отримувати практичні навички. } \\
\text { Кращі оцінки часто отримують не ті діти, які мають } \\
\text { якісні знання, а ті, які краще вміють користуватися } \\
\text { технічними засобами та різними програмами. } \\
\text { Необ'єктивність оцінювання виконаних робіт, } \\
\text { оскільки часто діти їх виконують за чиєїсь допом- } \\
\text { оги (батьків, друзів, спеціальних програм тощо). } \\
\text { Перехід від теорії до виконання практичних } \\
\text { завдань відбувається значно повільніше, ніж під } \\
\text { час звичайного навчання. } \\
\text { Низький рівень засвоєння і відпрацювання прак- } \\
\text { тичних навичок, тільки сильномотивовані учні, які } \\
\text { навчені самі вчитися, мають високий рівень. } \\
\text { Відсутність спілкування, що перешкоджає форму- } \\
\text { ванню соціальних навичок. } \\
\text { Діти звикають відразу отримувати результат: ви- } \\
\text { конав роботу - відразу оцінка. Ає довгострокові } \\
\text { результати, де треба тривалий час працювати, } \\
\text { щоб виконати завдання. } \\
\text { В освітньому процесі домінує процес навчання, } \\
\text { виховний процес нівелюється. }\end{array}$ \\
\hline
\end{tabular}




\begin{tabular}{|c|c|c|}
\hline Учителі & $\begin{array}{l}\text { Підвищення } \\
\text { рівня комп'ю- } \\
\text { терної грамот- } \\
\text { ності, ознайом- } \\
\text { лення з новими } \\
\text { програмними } \\
\text { продуктами, } \\
\text { отримання на- } \\
\text { вичок роботи з } \\
\text { ними. } \\
\text { Краще ро- } \\
\text { зуміння учнів } \\
\text { учителями } \\
\text { щодо мож- } \\
\text { ливостей } \\
\text { одночасного } \\
\text { користування } \\
\text { різними гадже- } \\
\text { тами. } \\
\text { Менше напру- } \\
\text { жуються голо- } \\
\text { сові зв'язки, бо } \\
\text { немає потреби } \\
\text { говорити го- } \\
\text { лосно на весь } \\
\text { клас. } \\
\text { З'явились нові } \\
\text { можливості } \\
\text { наочного } \\
\text { відображення } \\
\text { змісту навчан- } \\
\text { ня, процесів, } \\
\text { явищ тощо. } \\
\text { 3'явилось } \\
\text { багато гото- } \\
\text { вого контенту } \\
\text { для перевірки } \\
\text { якості освіти. }\end{array}$ & $\begin{array}{l}\text { Погіршення зору через тривале користування } \\
\text { комп'ютером. } \\
\text { Багато часу витрачається вчителями на підготовку } \\
\text { інструкцій щодо виконання певного завдання. Як } \\
\text { наслідок, немає фізичної можливості реалізову- } \\
\text { вати індивідуальний підхід до учнів. Створюється } \\
\text { універсальна інструкція для учнів однієї вікової } \\
\text { групи. } \\
\text { Часто вчитель не може перевірити включеність } \\
\text { учня в роботу на уроці: за аватаркою цього не } \\
\text { видно. } \\
\text { Часто неможливо відслідкувати емоційну реак- } \\
\text { цію дітей на зміст освіти: за аватаркою цього не } \\
\text { видно. } \\
\text { Перехід від теорії до виконання практичних } \\
\text { завдань відбувається значно повільніше, ніж під } \\
\text { час звичайного навчання. } \\
\text { Через екран комп'ютера вчитель не може пе- } \\
\text { ревірити хід виконання дітьми завдань на різних } \\
\text { етапах уроку. } \\
\text { Низький рівень засвоєння й відпрацювання прак- } \\
\text { тичних навичок, тільки сильно мотивовані учні, } \\
\text { які навчені самі вчитися, мають високий рівень. } \\
\text { Контроль рівня засвоєння знань та отримання } \\
\text { практичних навичок ускладнився, неможливо } \\
\text { об'єктивно здійснити перевірку. } \\
\text { Не вистачає спеціального навчання педагогів } \\
\text { щодо ознайомлення з можливостями викори- } \\
\text { стання різних комп'ютерних програм в освітньому } \\
\text { процесі. } \\
\text { Неналежне технічне забезпечення дистанційного } \\
\text { навчання: освітні установи не забезпечують педа- } \\
\text { гогів комп'ютерами, телефонами, камерами тощо. } \\
\text { Наявне програмне забезпечення може бути } \\
\text { англомовним, що ускладнює процес його викори- } \\
\text { стання вчителями в освітньому процесі. } \\
\text { учителі усвідомлюють, що засвоєння учнями } \\
\text { пноблем якості дистанційної освіти, оскільки лише } \\
\text { мотивовані учні й наявні вміння самостійно вчи- } \\
\text { тись допомагають їм засвоїти зміст. } \\
\text { нюється не на належному рівні. Тому є гнітюче } \\
\text { відчутт, що колись, коли буде навчання офф- } \\
\text { лайн, доведеться ліквідовувати прогалини, щоб } \\
\text { дитина могла далі рухатись у засвоєнні змісту } \\
\text { освіти. }\end{array}$ \\
\hline
\end{tabular}




\begin{tabular}{|l|l|l|}
\hline Батьки мають & Батьки мають контролювати процес навчання, \\
бути поінфор- & іноді надмірно, що перешкоджає розвитку само- \\
мованими в & стійності дітей і їхної власної відповідальності за \\
усьому, що сто- & процес і результат навчання. \\
сується здобутя & Через наявну необхідність контролювати всі \\
освіти дитиною: & процеси (вчасне підключення дитини до заняття, \\
бачити всі & активна участь на уроці, виконання домашніх \\
результати ро- & завдань тощо) батьки мають психологічні пробле- \\
боти, звернути- & ми. \\
ся до інструкцій & Не всі батьки мають фінансову можливість забез- \\
щодо вико- & печити свою дитину якісною технікою та якісним \\
нання завдан- & Інтернетом. \\
ня, отримати & У приватних закладах батьки платять повну суму \\
інформацію & за навчання, але отримують не всі послуги: діти \\
про навчання & навчаються, але не харчуються в освітній установі. \\
дитини з різних & \\
предметів & \\
на певному & \\
етапі, домашні & \\
завдання тощо. & \\
\hline
\end{tabular}

У таблиці 1.2 узагальнено переваги та недоліки комп'ютерної системи навчання (KCH) і педагога (традиційної системи навчання в класі).

Таблиця 1.2

Переваги та недоліки комп'ютерної системи навчання (КСН) і педагога (традиційної системи навчання в класі)

\begin{tabular}{|c|c|c|}
\hline & Педагог & $\mathrm{KCH}$ \\
\hline Переваги & $\begin{array}{l}\text { - можливість використання } \\
\text { діалектичної логіки й при- } \\
\text { родної мови; } \\
\text { - можливість смислового } \\
\text { аналізу відповідей учнів; } \\
\text { - можливість адекватного } \\
\text { вирішення будь-якої дидак- } \\
\text { тичної ситуації й опера- } \\
\text { тивної зміни ходу процесу } \\
\text { навчання; } \\
\text { - можливість обліку будь-я- } \\
\text { ких особистісних і діяльніс- } \\
\text { них характеристик учнів; } \\
\text { - можливість оперативного } \\
\text { вироблення навчальних } \\
\text { впливів у ході процесу } \\
\text { навчання; } \\
\text { - можливість індивідуалізації } \\
\text { навчання в малих (5 } \pm 2) \\
\text { групах }\end{array}$ & $\begin{array}{l}\text { • потенційна можливість індивіду- } \\
\text { алізації навчання у великих групах } \\
\text { учнів; } \\
\text { - висока швидкість і безпомилковість } \\
\text { оперативної обробки формалізова- } \\
\text { ної інформації; } \\
\text { - необмежені можливості в забез- } \\
\text { печенні наочності щодо уявлення } \\
\text { досліджуваних об'єктів; } \\
\text { - можливість оперативного відобра- } \\
\text { ження результатів взаємодії учнів із } \\
\text { будь-яким модельованим об'єктом } \\
\text { і, як наслідок цього, здатності за- } \\
\text { безпечити самостійне дослідження } \\
\text { досліджуваного об'єкта учнів; } \\
\text { - здатність сприймати інформа- } \\
\text { цію про дії того, хто навчається й } \\
\text { оперативно її аналізувати з метою } \\
\text { діагностування й оцінки якості } \\
\text { виконаних дій }\end{array}$ \\
\hline
\end{tabular}




\begin{tabular}{|c|c|c|}
\hline Недоліки & $\begin{array}{l}\text { • низька швидкість оператив- } \\
\text { ної обробки інформації; } \\
\text { - одностороння провідність } \\
\text { педагогічного спілкування } \\
\text { як каналу зв'язку; } \\
\text { - обмежені можливості в } \\
\text { забезпеченні наочності } \\
\text { уявлення досліджуваних } \\
\text { об'єктів }\end{array}$ & $\begin{array}{l}\text { • неможливість використання діалек- } \\
\text { тичної логіки й обробки неформалі- } \\
\text { зованої інформації; } \\
\text { - можливість тільки синтаксичного } \\
\text { аналізу відповідей учнів; } \\
\text { - можливість дозволу тільки заздале- } \\
\text { гідь формалізованих дидактичних } \\
\text { ситуацій і неможливість оператив- } \\
\text { ної зміни заздалегідь спланованого } \\
\text { процесу навчання; } \\
\text { - можливість обліку обмеженого } \\
\text { числа } \\
\text { формалізованих і контрольованих } \\
\text { особистісних і діяльнісних характе- } \\
\text { ристик учнів }\end{array}$ \\
\hline
\end{tabular}

Узагальнюючи визначені аспекти й контексти організації й здійснення дистанційного навчання, маємо також ураховувати певні психолого-дидактичні вимоги.

До школи зараз приходять абсолютно нові за типом мислення учні, які адаптовані до віртуальної реальності, діти, що ніколи не жили без інтернету. Якщо орієнтуватися на «теорію поколінь» (Нейл Хоув, Вільям Штраус), нині за партами сидить покоління Z - «цифрові» діти. Це покоління, яке народилося в інформаційному суспільстві, а першою іграшкою для них стає смартфон. Це діти мультимедійних технологій. До них застосовується термін "digital native", покоління носіїв діджиталізації. Дітей цього покоління вирізняє насамперед максимальна наближеність до інформації, з якою вони вміють відмінно працювати, вони залежні від цифрових технологій. Вибір - їхня головна цінність, пошук - це те, що вони вміють найкраще. Для них завжди існує найцікавіший сайт, найсвіжіша інформація - треба лише знайти. Вони здатні швидко «просівати» великі обсяги інформації, одночасно листуватися з десятком людей й оперативно реагувати на нові повідомлення. Отже, говорити про «середнього» учня в сучасній школі зараз не доводиться.

Інформаційно збагачене середовище впливає на механізм сприйняття й усвідомлення інформації, «цифрові» діти часто мають слабку пам'ять і проблеми з концентрацією уваги. Говорити з ними необхідно «твітами», тобто, стисло і з перервами. Подробиці їх особливо не цікавлять. Ігнорують довгі тексти й звертання, особливо усні. Отже, задушевні розмови й лекції - не для них. Вони - діти гаджетів. Майже не читають паперових книг, хоча літери вивчають з пелюшок, щоб знайти 
мультики в YouTube. Для таких учнів підручники, навіть в електронному вигляді, видаються нудними без лінків і відео.

Інтерпретуючи різні наукові дані, М. Prensky (Пренски) дійшов висновку про те, що розумові процеси цифрової людини не лінійні, а паралельні. Мислення сучасної молоді відрізняється інтенсивністю когнітивних навичок у навчанні. Такі діти використовують інші форми концентрації уваги, що обумовлюється існуванням (потребою існування) в інтерактивному середовищі. Для «цифрових дітей» характерними є мультизадачність, коротка концентрація уваги, прискорене переключення, вони сприймають інформацію з мінімальною кількістю слів та обов'язковою візуалізацією (картинки або коротке відео), для них важлива персоналізація та простота в комунікації.

Покоління Z іде від усього, що викликає дискомфорт. Життя для «цифрових» - це пошук. Стосунки вони легко обривають одним повідомленням й одразу переглядають нові кандидатури в соцмережах. Школярі кидають недоробленим домашнє завдання, хоча здатні його виконати. Домашнє завдання їм необхідно розсилати на гаджети. Будьяке завдання краще розбивати на десяток дрібних. Розписувати кожен крок і не сподіватися на допитливість. Шаблони не обмежують, а, навпаки, заспокоюють покоління Z. А креативність вмикається, коли вони знаходять недоліки в шаблонах або шукають нові версії.

Подання матеріалу на уроці, цікавість, елемент гри ще ніколи не були настільки важливі. А ще - зручність. У приватних школах вже зрозуміли, що комфортні, стильні та модернізовані класи спонукають сучасних дітей бігти на заняття. Якщо матеріальна база не відповідає вимогам, використовуйте оригінальні роздруківки та нестандартне оформлення кабінету.

Сучасні діти збиваються у віртуальні «зграї». Належність до групи в соцмережах для них надзвичайно важлива. Друзі нагадують їм персонажів комп'ютерної гри із заданими параметрами. Варто завести для класу групу в соцмережі. Але ії мають вести діти, а не дорослі. Час від часу доцільно розміщувати те, що спонукатиме до обговорення навчання. Сучасних дітей треба вчити розуміти власні й чужі почуття, звертати увагу на складність і унікальність особистості. У навчанні варто спиратися на любов до публічності. Запропонуйте учням зняти відео про виконання досліду. Вони зроблять це охочіше, ніж записуватимуть результати в зошит.

Сучасні підлітки не переймаються життєвими цілями. Учитися діти теж мріють вдома. Багато з них ще підлітками заробляють як фрілансери, оскільки в інтернет-реальності важливі вміння, а не атестати й дипло- 
ми. Водночас цьому поколінню Z не потрібні захмарні зарплати, а той мізер, який їм треба, вони можуть легко отримати у будь-якому місці. Вони можуть брати участь у важливих міжнародних проєктах, але одночасно сидіти голодними, доки мама не зготує вечерю. Учителям необхідно тісно спілкуватися з батьками - вони й «домашку» роблять, й інтереси старшокласників представлять.

Нездатність зосередитись і постійне відволікання - так описують сучасних школярів учителі, психологи й фахівці освіти. Як захопити увагу покоління, народженого з ґаджетом у руці?

- Не перевантажувати інформацією. Покоління Z хоче отримувати «концентровані» знання. Крім того, вони свідомо ігнорують етапи уроку, спрямовані на «закріплення» матеріалу за допомогою його багаторазового повторення: як тільки вони зрозуміють суть навчального матеріалу, подальше повторення того самого стає «недоречним».

- Ставити перед учнями зрозумілі реальні цілі. Представники «покоління Z» готові робити все максимально ефективно, але для цього вони мають знати, що саме від них вимагають.

- Допомогти зрозуміти, для чого учневі потрібна певна інформація, і надати найкращу можливість скористатися нею.

- Зробити навчальний матеріал «яскравим і візуалізованим». Покоління Z найкраще сприймає візуальну інформацію.

- Залучати учнів до довгострокових проєктів, які дадуть можливість культивувати терпіння й наполегливість.

- Створити в навчальному закладі комфортні умови, які відповідатимуть запитам цих дітей: надати можливість для підзарядки ґаджетів, використовувати WI-FI, мультимедійні дошки, зручні місця для відпочинку, нестандартне оформлення інтер'єру тощо.

- Трансформувати освітній процес відповідно до рекомендацій зарубіжних і вітчизняних учених, педагогів-практиків.

- Постійно підвищувати педагогічну інформаційну грамотність і використовувати сучасні гаджети в освітньому процесі.

\section{2. ПРОЄКТУВАННЯ ОСВІТНЬОГО СЕРЕДОВИЩА ЗАКЛАДУ ЗАГАЛЬНОЇ СЕРЕДНЬОЇ ОСВІТИ З УРАХУВАННЯМ ОСОБЛИВОСТЕЙ ДИСТАНЦІЙНОГО ТА ЗМІШАНОГО НАВЧАННЯ}

Проєктування освітнього середовища закладу загальної середньої освіти відповідно до Концепції Нової української школи має бути спрямоване на побудову комфортної та безпечної атмосфери для суб'єктів 
освітнього процесу, яка сприяє їх особистісному розвитку й соціальному становленню.

Важливість розв'язання проблеми проєктування освітнього середовища зумовлена необхідністю його цілісного оновлення відповідно до загальних трансформаційних змін, які відбуваються в суспільстві. Так, важливим скеладником освітньої системи XXI століття стає дистанційна освіта як найбільш перспективна, синтетична, гуманістична та інтегральна її форма. Особливої актуальності вона набуває в епідеміологічних умовах, коли явище карантину стає доволі регулярним.

Дистанційна освіта розглядається здебільшого як комплекс освітніх послуг, що надаються широким верствам населення у країні та за її межами за допомогою спеціалізованого інформаційного освітнього середовища, яке базується на засобах обміну навчальною інформацією на відстані (супутникове телебачення, радіо, комп'ютерний зв'язок тощо).

Дистанційне навчання має особливості, які вигідно відрізняють його від інших форм освіти. Це: гнучкість - навчання відбувається у зручний для здобувача освіти час та в зручному місці; модульність - із набору незалежних курсів-модулів формується навчальна програма, що відповідає індивідуальним чи груповим потребам; охоплення великої аудиторії одночасне звернення до багатьох джерел навчальної інформації великої кількості учнів та їх спілкування за допомогою телекомунікаційного зв'язку між собою та з викладачами; економічність - ефективне використання навчальних площ та технічних засобів, концентроване й уніфіковане представлення інформації, використання і розвиток комп'ютерного моделювання; технологічність - використання в освітньому процесі нових досягнень інформаційних технологій, які сприяють входженню людини у світовий інформаційний простір; соціальна рівність - рівні можливості здобуття освіти незалежно від місця проживання, стану здоров'я й соціального статусу; інтернаціональність - можливість одержати освіту в навчальних закладах іноземних держав та надавати освітні послуги іноземним громадянам і співвітчизникам, що проживають за кордоном; нова роль викладача - викладач стає наставником-консультантом, який повинен координувати пізнавальний процес, постійно удосконалювати ті курси, які він викладає, підвищувати творчу активність і кваліфікацію відповідно до нововведень та інновацій; позитивний вплив на слухача; якість - для підготовки дидактичних засобів залучається найкращий професорсько-викладацький склад і використовуються найсучасніші навчально-методичні матеріали [3].

Для дистанційного навчання сьогодні є дуже багато можливостей. Дистанційна освіта передбачає доступ до інтернету, технічне забезпе- 
чення (комп'ютер, планшет, смартфон тощо) усіх учасників освітнього процесу, а також володіння вчителями технологіями дистанційного навчання. Мережа Інтернет постійно розширює свої сервіси, розміщує інформацію, яка є значущою з погляду освіти. Інтернет-навчання, як основа безперервної освіти, спрямоване на набуття учнями навичок самоосвіти. Підвищується актуальність питань, пов'язаних з організацією навчання різних вікових груп учнів, з вибором інтернет-платформ для організації освітньої діяльності учнів, поєднанням традиційних методів навчання зі специфічними для дистанційної освіти. Дистанційна форма навчання забезпечує неперевершену швидкість відновлення знань, що отримуються зі світових інформаційних ресурсів; дає змогу без обмежень розширити аудиторію викладача, наблизитись до специфічних потреб осіб з інвалідністю при здобутті ними освіти; особливої актуальності набуває в умовах довготривалого карантину, який спричинюється епідеміями та пандеміями [62].

Результати аналізу психолого-педагогічної літератури з проблеми дослідження показали, що поняття «педагогічне проєктування» розглядається ученими і практиками як інтегративна діяльність, що установлює в інноваційному процесі єдність теоретико-методологічних і практико-технологічних складників та утверджує сутність інновації отримання реальних стійких результатів, які характеризуються новизною й ефективністю. Технологія проєктування освітнього середовища закладу загальної середньої освіти полягає у визначенні: мети та концептуальних засад його побудови; системного бачення основних його структурних елементів; чинників впливу на розвиток та реформування цих складників; критеріїв і показників перевірки ефективності розробленого проєкту освітнього середовища, послідовності етапів реалізації цієї технології [91].

У ході дослідження було визначено, що до чинників впливу на процес формування освітнього середовища відноситься сукупність явищ і процесів, які в предметно-рекреаційному, просторово-часовому, інформаційному, комунікативно-діяльнісному, морально-психологічному та інших аспектах пов'язані з освітнім процесом. У цьому сенсі проєктування і створення освітнього середовища включає систему цілеспрямованих дій щодо актуалізації предметних, інформаційних, психологічних, чинників, які забезпечують підтримку цілеспрямованої науково-педагогічної діяльності учителів і саморозвитку учнів.

Аналіз сучасних тенденцій розвитку питання освітнього середовища в освітній теорії і практиці показав, що одним із пріоритетних напрямів 
його трансформування й розвитку нині, в умовах частих карантинів, $\epsilon$ налаштування процесу дистанційного навчання [5].

До специфічних особливостей дистанційного навчання під час карантину можна віднести попередню невизначеність із термінами проведення. Це явище тимчасове і заздалегідь не відомо, коли воно може розпочатися. Тому розробки з дистанційного навчання мають бути цілісними, систематизованими за курсами, темами, щоб можна було розпочати навчання у будь-який період навчального року. Перелік предметів чи тем навчальних програм, видів навчальних занять, які здійснюються за технологіями дистанційного навчання, визначаються закладами освіти. Сучасна дистанційна освіта відбувається переважно у віртуальному освітньому просторі, який передбачає проєктування освітнього середовища з урахуванням новітніх комп'ютерних технологій. Як показало дослідження, ключовими питаннями, які потребують врахування в процесі проєктування освітнього середовища закладів загальної середньої освіти в умовах дистанційного навчання, є: науково-методичне, навчально-методичне забезпечення освітнього процесу, питання ефективної педагогічної взаємодії учасників цього процесу та питання адміністрування [94].

Науково-методичне забезпечення дистанційної освіти включає: методичні (теоретичні та практичні) рекомендації щодо розроблення й використання педагогічно-психологічних та інформаційно-комунікаційних технологій дистанційного навчання; критерії, засоби і системи контролю якості дистанційного навчання; змістове, дидактичне та методичне наповнення вебресурсів.

Нині дистанційне навчання розглядається як нова педагогічна технологія або комплекс, що використовує у взаємодії та взаємодоповненні всі відомі технології навчання й керується основними законами педагогіки, хоч і трансформує їх згідно з новими умовами навчання та потребує певного переосмислення в рамках освітніх закладів. До найефективніших відносять технологію змішаного навчання (blended learning) та ії різновид - технологію перевернутого навчання.

Змішане навчання - це освітня технологія, яка передбачає поєднання інформаційно-комунікаційних методів навчання з методами традиційного і самостійного навчання, поєднання аудиторних форм навчання 3 віртуально-мережевими. Мається на увазі не просто використання сучасних інтерактивних технологій на додаток до традиційних, а якісно новий підхід до навчання, що трансформує, а іноді й «перевертає» клас (flipped classroom) [84]. 
Змішаний характер навчання передбачає комбінацію різноманітних форм і систем навчання. Існують такі моделі змішаного навчання: 1 . Ротаційні моделі - організація курсу чи предмета таким чином, що учні (студенти) переходять між різними форматами навчання за фіксованим розкладом або на розсуд вчителя, принаймні одним з таких форматів $\epsilon$ навчання в режимі онлайн. 2. Гнучка модель - курс або предмет, у якому онлайн-складова $є$ основою навчання учнів, навіть якщо певна діяльність і відбувається в аудиторії. Учні працюють за індивідуальним гнучким графіком. Учитель доступний для будь-яких консультацій, заняття відбуваються здебільшого у приміщенні школи та виконуються індивідуальні домашні завдання. 3. Модель самостійного змішування - самостійні заняття онлайн змішується з відвідуванням навчальних заходів у школі чи в навчальному центрі. Педагог у цій моделі $\epsilon$ онлайн-учителем. 4. Модель збагаченого віртуального навчання - курс чи предмет, у якому здобувачі освіти зобов' язані проходити частину навчання зі своїм учителем, а потім завершувати індивідуальні завдання самостійно.

За технологією перевернутого навчання (англ. flipped classroom) основне засвоєння нового навчального матеріалу учнями відбувається вдома, а час аудиторної роботи відводиться на виконання завдань, вправ, проведення лабораторних і практичних досліджень, індивідуальні консультації вчителя. До переваг методу можна віднести такі: 1) набуття знань у зручний для учня час, в індивідуальному темпі, у зручній для нього формі (це може бути і відео, завантажене на смартфон чи планшет, аудіолекція, завантажена на плеєр); 2) індивідуальні консультації з учителем забезпечують зворотний зв'язок, підвищують упевненість й активність учнів; 3) на уроках час не витрачається на викладання нового матеріалу, завдяки чому створюється більше можливостей для застосування знань; 4) методика не потребує спеціальних дорогих технічних пристроїв. Для реалізації роботи в межах «перевернутого класу» може знадобитися звукозаписний пристрій (диктофон, мікрофон), камера або вебкамера, комп'ютер зі стандартним програмним забезпеченням; 5) учні можуть використовувати більшу кількість додаткових джерел за самостійної підготовки вдома: інтернет, домашні книги, словники.

Порадами для успішного застосування методу $є$ такі: його використання краще розпочинати на більш доступних для самостійної роботи учнів темах; обов'язковим $є$ навчально-методичний супровід (наявність підручників, тиражування підготовлених матеріалів, створення презентацій (бажано зі звуковим коментарем), відеороликів, відеомайстер-класів тощо); бажаним $€$ наявність партнерів-однодумців - співпраця з колегою полегшує роботу (можна обговорювати ідеї, створювати навчаль- 
ні ресурси, розподіляти обов'язки з підготовки матеріалів до занять); обов'язковим $€$ роз'яснення учням та їхнім батькам, як працює методика «перевернутого класу», в чому полягатимуть обов'язки учнів, чого слід чекати від таких уроків.

Навчальні заклади, як і вчителі, мають автономію, тож можуть налагоджувати співпрацю з учнями у будь-який зручний спосіб. Проте відомо, що отримання якісного результату в освітньому процесі передбачає його ретельне планування, проєктування та організацію.

Під час дослідження було визначено педагогічні умови забезпечення процесу проєктування дистанційного навчання: варіативна мобільність, яка полягає у створенні вебсередовища, вебресурсів, що дають змогу учневі коригувати або доповнювати свою освітню програму в необхідному напрямі; доступність навчального матеріалу для активної самостійної діяльності з його опрацювання; унаочнення навчального матеріалу; налаштування педагогічної взаємодії на основі застосування інтерактивних освітніх технологій; забезпечення зворотного зв'язку для оцінювання освітніх результатів; забезпечення оптимального поєднання очних і дистанційних форм освітньої діяльності [92].

Вебресурси навчально-методичного забезпечення, необхідні для забезпечення дистанційного навчання, можуть містити: методичні рекомендації щодо їх використання, послідовності виконання завдань, особливостей контролю; документи планування навчального процесу; відео- та аудіозаписи лекцій, семінарів тощо; мультимедійні лекційні матеріали; термінологічні словники; практичні; віртуальні лабораторні роботи із методичними рекомендаціями щодо їх виконання; віртуальні тренажери; пакети тестових завдань для проведення контрольних заходів, тестування із автоматизованою перевіркою результатів, тестування із перевіркою викладачем; ділові ігри із методичними рекомендаціями щодо їх використання; електронні бібліотеки чи покликання на них; бібліографії; дистанційні курси.

На окрему увагу заслуговує питання організації педагогічної взаємодії учасників освітнього процесу в умовах дистанційного навчання. Можливості інтернету та сучасних інформаційних технологій зумовлюють розвиток опосередкованої форми комунікаційного процесу. Традиційна парадигма освіти «викладач - підручник (інформація) - здобувач освіти» в умовах дистанційного навчання доповнюється новою схемою: «здобувач освіти - телекомунікаційні технології - викладач», що $\epsilon$ тенденцію до розвитку опосередкованих форм організації педагогічної взаємодії. Сутнісні характеристики поняття "взаємодія» лежать в основі педагогічної взаємодії і дають змогу виокремити його особливості - на- 
явність взаємовпливу, взаємодіяльності між суб'єктами педагогічного процесу, наявність єдиної мети як усвідомлюваного і запланованого результату, розподіл функціональних обов'язків між вчителем і учнями, спілкування. Педагогічна взаємодія завжди $є$ спеціально організованим процесом, спрямованим на вирішення навчально-виховних завдань. Організація дистанційної взаємодії віддалених один від одного суб'єктів навчання має бути спрямована на створення сприятливих умов для їх продуктивної діяльності, вирішення проблем взаєморозуміння, поетапного розвитку необхідних навичок комунікації, адекватну оцінку результатів навчання.

Для створення педагогічної взаємодії необхідно проєктувати умови, що сприяють: активному включенню всіх учасників освітнього процесу в обговорення і виконання дії при прийнятті рішень на різних етапах організації взаємодії; формуванню дослідницької позиції всіх суб'єктів освіти; об'єктивації поведінки, що передбачає отримання постійного зворотного зв'язку; побудові партнерського спілкування, що означає визнання та прийняття цінності особистості кожного, його думки, інтересів, особливостей, прагнень, перспективи особистісного зростання [93].

Для реалізації дистанційної освіти застосовуються такі знаряддя як блоги й мікроблоги, соціальні мережі і системи соціальних презентацій, вікі-проєкти, мультимедійні системи обміну інформацією, системи спільних редакторських офісів тощо. Під ці технологічні можливості відповідно розробляються нові освітні методичні підходи, які базуються на таких психологічно орієнтованих принципах побудови як: надлишковість, доступність спостереженню, когнітивному досвіду суб'єкта, насиченість освітнього середовища, його пластичність, позасуб'єктна просторова локалізація та автономність існування, синхронізованість середовища, векторність, цілісність, мотивогенність, іммерсивність, інтерактивність тощо.

До інструментів спілкування й засобів організації дистанційного навчання можна також віднести електронну пошту, форум, чат, відеоконференцію, блог, коментування у Twitter, скайп. Нові можливості для педагогічної взаємодії створює платформа Google Клас. Ця платформа дає можливість учителям заощаджувати час, легко і швидко організовувати заняття й ефективно спілкуватися з учнями. Клас - це новий сервіс Google Apps для освіти, який дає змогу педагогам швидко створювати та впорядковувати завдання, виставляти оцінки, залишати коментарі та спілкуватися з учнями. Своєю чергою, учні можуть зберігати завдання на Google Диску, а також здавати виконані роботи в Класі й 
безпосередньо спілкуватися один з одним і з педагогами. У Класі можна працювати з Google Документами, Google Диском i Gmail. Завдяки цьому вчителі можуть давати завдання і збирати готові роботи, забувши про стопки зошитів.

Педагог, розмістивши в інформаційній базі певний навчальний продукт - інформацію, створює авторизовану вебсторінку, на якій розміщено методичні матеріали для конкретного освітнього процесу. Учень у процесі виконання завдання створює свій продукт і розміщує його у тій самій інформаційній базі, створюючи свою авторизовану сторінку. Аналіз педагогічної практики показав, що досвідчені вчителі для організації освітньої діяльності учнів створюють google-таблиці, де кожен учень має доступ до коментування. Завдання поділені на основні, які мають дедлайни, та за вибором, що створюють індивідуальну траєкторію навчання і дають додаткові бали. Спілкування відбувається в чаті телеграм і майже не має часових обмежень. Комунікація відбувається у Zoom, а для тих, хто не може долучитися, готується запис.

Адміністрація школи має забезпечити організацію діяльності закладу освіти в умовах режиму дистанційного навчання, керувати вебсередовищем дистанційної освіти, узгодити правила та розклад взаємодій усіх учасників освітнього процесу для виконання освітніх програм закладу. Завдання керівника закладу освіти - обговорити зміну форм навчання з педагогічним колективом, вибрати онлайн-платформу, організувати й запровадити навчання з використанням дистанційних технологій.

Узагальнюючи викладене, слід підкреслити, що ключовими питаннями, які потребують врахування в процесі проєктування освітнього середовища закладу загальної середньої освіти в умовах дистанційного навчання, $\epsilon$ : науково-методичне, навчально-методичне забезпечення освітнього процесу, питання ефективної педагогічної взаємодії учасників цього процесу й питання адміністрування. Крім того, до специфічних особливостей організації дистанційної освіти учнів у процесі проєктування освітнього середовища гімназії можна віднести такі: вона потребує створення інформаційної бази для збереження й адаптування навчальних матеріалів до вебсередовища та викладення їх на вебресурсах; спеціального обладнання для повноцінного функціонування; передбачає спеціалізовану організацію роботи учнів за цією освітньою технологією; потребує врахування специфіки розроблення, побудови й публікації матеріалів у вірту- 
альному середовищі. Перелічені специфічні особливості організації дистанційної освіти мають набути розвитку в подальших дослідженнях цієї проблеми.

\section{3. РОЛЬ ДИСТАНЦІЙНОГО НАВЧАННЯ В ДОСЯГНЕНІ МЕТИ ДЕРЖАВНОГО СТАНДАРТУ ЗАГАЛЬНОЇ СЕРЕДНЬОЇ ОСВІТИ}

3 метою методичної підтримки керівників і педагогів закладів освіти різних рівнів щодо досягненя мети освітніх стандартів в умовах дистанційного навчання співробітниками відділу інтеграції змісту загальної середньої освіти розроблено відеолекції, які проводились для педагогів Дніпропетровської, Полтавської, Рівненської областей та представлені на електронних ресурсах:

https://www.youtube.com/watch?v=q9napzjtJX4\&t=9s;

https://www.youtube.com/watch?v=WUUjjsKVOb0;

https://www.youtube.com/watch?v=2RdnfpHq7KI\&t=185s;

https://www.youtube.com/watch?v=xgzZYHZO4Uk\&t=455s;

https://www.youtube.com/watch?v=6QvlWgPisV8\&t=581s.

У відеолекціях висвітлюються питання:

- формування Державних стандартів освіти (дошкільної, початкової, базової, профільної) як умови розвитку й виховання всебічно розвиненої, освіченої інноваційної особистості;

- аналіз навчально-методичного забезпечення реалізації ДС (для відповідної категорії слухачів);

- аналіз втіленої у навчально-методичному забезпеченні технології контролю за формуванням особистості учнів;

- образ світу учнів як показник сформованості особистості учнів на всіх етапах навчання.

Висвітлено завдання Державного стандарту освіти й схарактеризовано засоби і методи їх досягнення. Конкретизовано Концепцію реалізації державної політики у сфері реформування загальної середньої освіти «Нова українська школа».

Зміст освіти розглядається як система наукових знань про природу, суспільство, людське мислення, практичних вмінь і навичок та способів діяльності, досвіду творчої діяльності, світоглядних, моральних ідей і відповідної поведінки, якими має оволодіти учень у процесі навчання. Зміст освіти має будуватися на науковій основі («Наука починається там, де мислення опирається на закони, відкриті наукою», - B.І. Вер- 
надський) і спрямовуватися на досягнення основної мети формування особистості громадянина України.

Акцентовано увагу на тому, що засвоєння учнями цілісності змісту освіти обумовлює цілісність свідомості учнів, можливості досягнення ними природовідповідно високих рівнів інтелекту, оволодіння компетентностями, які пропонуються програмами.

Здійснено аналіз навчально-методичного забезпечення різних рівнів (програм, підручників, посібників для учнів та вчителів) як інструментарію формування в учнів наукової картини світу - системи наукових знань про природу, людину та суспільство.

Стандарт освіти розглядається як система основних параметрів, що сприймаються за державну норму освіченості, яка відображає соціальний ідеал і враховує можливості реальної особистості й системи освіти щодо досягнення цього ідеалу. Стандарт освіти визначає обов'язковий мінімум змісту основних освітніх програм, вимоги до підготовки учнів і $€$ основою для створення навчальних програм, підручників, за допомогою яких стандарт освіти реалізується в усіх ланках освіти.

Навчальні програми характеризуються як системні документи, що визначають цілі й завдання кожного предмета, його зміст, набуття учнями ключових компетентностей та творення ефективних механізмів їх запровадження, а також урок як ключовий елемент реалізації стандарту освіти. Акцентовано увагу на умовах навчально-виховної взаємодії: її гуманності, цілісності й системності освітнього процесу; особистісній спрямованості навчання на формування в учнів життєствердного національного образу світу; співпраці учителів у формуванні наукової картини світу, її особистісно значущому складникові - образу світу учнів; взаємній узгодженості вимог школи і батьків до виховання й розвитку учня, яка може коригуватися за допомогою дидактичного забезпечення.

Для реалізації зазначених умов необхідно, щоб зміст стандарту, втілений у програмах і підручниках, ритм навчального процесу, спілкування з батьками, ритм уроку, навчальне середовище - все працювало на задоволення учнівських прагнень: до дослідження, які проводяться учнями, й отримання висновків; конструювання; комунікації; художнього представлення досліджених об'єктів під час їх презентації. Такий процес реалізації стандарту освіти (початкової, базової, профільної) потребує систематичних уроків з усіх предметів у середовищі життя учнів, на яких вони проводять дослідження 
з подальшим моделюванням пізнаних об'єктів, презентацією своїх виробів.

Досвід роботи педагогів моделі освіти для сталого розвитку «Довкілля» довів, що така реалізація стандарту освіти дає можливість учням набути високих рівнів інтелекту, високих рівнів соціальної зрілості, цілісного світогляду, зміцнювати фізичне здоров'я, формувати свій життєствердний національний образ світу і поповнювати суспільство з життєствердною моделлю світу - умовою його довговічності.

Акцентовано увагу на тому, що ключовим принципом формування наукової картини світу $є$ наскрізне відображення в змісті та методах навчання загальних закономірностей природи, суспільства, культури. У процесі формування наукової картини світу має формуватися життєствердний, заснований на загальних закономірностях, образ світу учнів як складник наукової картини світу, що включає цінності, уподобання учня, його можливості в досягненні ідеалу. Образ світу - вихідний пункт і результат будь-якого пізнавального процесу, взаємодії особистості з дійсністю.

Формування наукової картини світу, життєствердного національного образу світу пов'язано з етнопедагогікою, із засвоєнням учнями історично зумовлених і створених народом сукупності ідеалів, поглядів, переконань. Технологію формування наукової картини світу, життєствердного національного образу світу в суб'єктів освіти всіх рівнів (дошкільної, початкової, базової, профільної) втілено в навчально-методичному забезпеченні моделі освіти для сталого розвитку «Довкілля» [26; 90]. 


\section{РОЗДІЛ 2}

\section{ОСОБЛИВОСТІ ДИСТАНЦІЙНОГО НАВЧАННЯ В ЗАРУБІЖЖІ}

Дистанційна освіта (Distance Education) трактується як освіта, яку отримують на відстані за допомогою інформаційно-комунікаційних технологій: радіо, телебачення, телефону, листування, електронної пошти, відеоконференцій, аудіоконференцій, компакт-дисків або інтернету [125].

Паралельно з використанням терміну “дистанційне навчання» в англомовному контектсі трапляється термін «віддалене навчання» (Remote Learning). Обидва описують спосіб доставки навчального змісту, який здійснюється на відстані через різні засоби зв'язку та участі у освітній діяльності, проте існують істотні відмінності. Дистанційне навчання термін, який використовувався до розповсюдження цифрових засобів навчання і первісно був пов'язаний із заочним навчанням. Його використовували для того, щоб краще описати фізично віддалене місцезнаходження учня й окреслити стиль його спілкування з учителями. Нині терміном «дистанційне навчання» здебільшого позначається онлайн-навчання студентів для здобуття сертифікації, наукового ступеня або розвитку нових навичок. Воно, як правило, $є$ більш гнучким, ніж віддалене навчання, і дає змогу студентам самостійно налаштовуватися на лекції та онлайн-курси в певні терміни.

Термін «віддалене навчання» здебільшого позначає забезпечення неперервності навчання під час планування конфліктів, хвороб або пандемій (як COVID-19) [123]. Фактично віддалене навчання $€$ втіленням традиційного класу, переміщеного в онлайн-середовище.

Дистанційне навчання не завжди є онлайн-навчанням - його засобами можуть бути офлайнові мультимедійні (записані на електронні носії інформації) або друковані матеріали, тоді як онлайн-навчання передбачає форму організації занять із перебуванням учасників освітнього процесу в мережі та здійснення ними навчальної діяльності в інтернеті в режимі реального часу.

Дистанційне навчання може здійснюватися у двох режимах: синхронному (Synchronous Mode) та асинхронному (Asynchronous Mode). 
За синхронного режиму всі учасники освітнього процесу одночасно перебувають у веб-середовищі через чат, аудіо-, відеоконференцію, соціальні мережі тощо. За асихронного режиму освітній процес здійснюється за зручним для вчителів та учнів графіком через електронну пошту, форум, соціальні мережі, блог, анкетування тощо. Синхронний режим надає можливість співпрацювати в режимі реального часу. Перевага синхронного режиму в тому, що можна залучати учасників миттєво та у визначений час. Асинхронний режим може включати різноманітні засоби інформації, аудіо- та відеоуроки (але не обмежуватися ними). За допомогою асинхронного режиму навчання учні можуть працювати у власному темпі, в зручний для себе час і з різних географічних локацій.

Однією з особливих проблем, яку продемонструвала пандемія COVID-19, є необхідність постійного моніторингу даних, аналізу інформації, розроблення рекомендацій, координації дій у різних секторах, зокрема освітньому, у короткостроковій, середньо- та довгостроковій перспективі. Такі функції взяли на себе передусім міжнародні організації глобального рівня (ЮНЕСКО, ОЕСР) Їх рекомендації стали універсальними, оскільки враховують потребу будь-якої країни у визначенні власних пріоритетів з огляду на національні традиції та освітні стандарти і спираються на демократичні принципи в управлінні освітою, зокрема налагодження стійкого соціального діалогу з усіма партнерами для прийняття ефективних управлінських рішень. В умовах поширення пандемії COVID-19 міжнародні організації швидко відреагували на загрози через комплексність ініціатив, ключовими складниками яких стали фінансова підтримка, налагодження систем об'єктивного інформування, об'єднання й координування зусиль партнерів і країн [8].

В умовах закриття закладів освіти ОЕСР наголошувала на необхідності мобілізувати для організації дистанційного навчання різні форми інтернет-освіти й освітніх ресурсів та розширити можливості цифрового навчання [113]. Для ефективного впровадження дистанційного навчання ЮНЕСКО рекомендує передусім визначити можливості інфраструктури, вивчити різні варіанти інструментів онлайн-навчання, навчити вчителів механізму залучення всіх учнів до онлайн-навчання через інструменти дистанційного навчання, застосовувати комбіновані підходи до організації навчання, використовувати інструменти, сумісні зі смартфонами, оскільки вони є більш доступними для великої кількості здобувачів освіти тощо [110].

Перспективною в умовах дистанційного навчання розглядається академічна підтримка учасників освітнього процесу, а саме: забезпечення мотивації та професійного розвитку вчителів, забезпечення мотивації, якості, рівність і включення у навчання всіх учнів, створення віртуаль- 
них спільнот практик вчителів та учнів для спільного вирішення освітніх питань тощо.

Важливим є те, що такі міжнародні організації постійно моніторять ситуацію та гуртують міжнародну спільноту для розв'язання нагальних проблем у галузі освіти. Через рік після початку пандемії COVID-19 під егідою ЮНЕСКО у березні 2021 р. було проведено зустріч 85 міністрів освіти з питань вироблення подальшої освітньої стратегії та адаптації систем освіти до нових реалій. Було підкреслено, що майже половина учнів у світі досі потерпає від часткового або повного закриття шкіл, i, що через пандемію навички читання понад 100 млн. дітей виявляються нижче мінімального рівня. Під час обговорень також було зазначено: як показала пандемія, школи неможливо повністю замінити на інший формат і жоден комп'ютер не може замінити вчителя. Під час круглого столу, присвяченого підтримці вчителів і відкритості шкіл, міністри наголосили на необхідності стійких та новаторських шкільних систем для протистояння нинішнім та майбутнім непрогнозованим викликам:

- щодо втрат у навчанні було акцентовано увагу на справедливості, подвоєнні інвестицій у систему корекційної освіти, у зміцненні соціальних служб, визначенні пріоритетів для наймолодших дітей та в формулах фінансування;

- щодо питань цифрової трансформації освіти - наголошувалося на необхідності зосередитись на важливості підготовки вчителів та їх професійному розвиткові, на державно-приватному партнерстві та залученні суспільства для сприяння розвитку навичок XXI століття і працевлаштування молоді.

Для підтримки національних стратегій ЮНЕСКО, ЮНІСЕФ та Світовий банк оголосили про спільну місію «Відновлення освіти 2021», зосередившись на трьох пріоритетах:

- забезпечити повернення до школи усіх дітей і юні з наданням усебічної підтримки включно психо-соціальною, охороною здоров'я, харчуванням;

- прискорити навчання та подолати розрив у цифровому навчанні;

- здійснити підготовку всіх учителів та розширити їх можливості [126].

Серед викликів дистанційного навчання та співпраці в онлайн-середовищі міжнародні організації звертають увагу на збалансування цифрового та не-цифрового навчання, підтримку емоційного здоров'я учнів, рівний доступ до цифрових пристроїв або альтернативних ресурсів, а також злагоджене управління IT-інфраструктурою.

Попри численні розробки та дослідження у галузі інноваційних, зокрема цифрових технологій, переважна більшість систем освіти опинилися у кри- 
зовому стані та виявилися неготовими до їх упровадження. Вчителі мали адаптуватися до нових педагогічних концепцій та способів викладання, до яких більшість не були готові. Так, за даними опитування, яке провела комунікаційна платформа для вчителів і батьків ClassTag з метою з'ясування того, як вчителі початкової та середньої школи впроваджують дистанційне навчання, більше 56,7\% респондентів відповіли, що вони не готові впроваджувати дистанційне навчання. На запитання про те, як вони планують урок та якими онлайн-інструментами користуються, більшість (68,8\%) відповіли, що це навчальна програма у письмовому вигляді, лише кожен третій $(34,1 \%)$ заявив, що використовує або планує використовувати відеозаписи, і лише 12,7\% заявили, що користуються потоковим мовленням та проводять уроки онлайн. Щодо онлайн-інструментів, то більшість викладачів називали Google Drive та Google Classroom, проте жоден продукт не набрав більше 10\%. Лише 7\% вчителів згадали про такий ресурс як Еріс!, a Kahn Academy не набрав навіть і 4\%. На думку фахівців, це стало ударом по edtech-галузі, яка витратила роки та мільярди доларів на розробку та маркетинг продукції [120].

Міжнародні практики організації навчального процесу в режимі дистанційного навчання підтверджують висновки ЮНЕСКО та ОЕСР і зазначають, що під час трансформації освітнього процесу в режим дистанційного навчання країни стикалися з серйозними викликами у процесі організації через недорозробленість законодавчо-нормативної бази трансформації навчального процесу на онлайн-платформу; негнучкість або повільність реагування органів влади щодо адаптації змісту освіти для проведення онлайн-навчання вчителями; брак/недостатність високоякісного та сучасного навчально-методичного забезпечення; складність трансформації практико-орієнтованих навчальних предметів/видів роботи в онлайн-формат; неготовність педагогів проводити онлайн-уроки через недостатнє володіння IKT навичками і методиками проведення онлайн-занять; брак технічних можливостей у певних сім'ях; небезпека для здоров'я учнів через тривале перебування перед моніторами пристроїв та невідпрацьованість системи регуляції цього процесу тощо [8].

Водночас позитивною тенденцією стали інноваційні підходи до вирішення нагальних проблем на різних рівнях управління та пошуку ефективних інструментів організації навчального процесу. Під час пандемії майже кожна європейська країна мала власну стратегію навчання школярів, застосовуючи різні підходи залежно від динаміки і масштабу поширення вірусу. Більшість країн звернулися до інформаційно-комунікаційних технологій, спонукаючи вчителів переходити до онлайн-уроків. 
Серед базових інструментів дистанційного навчання країнами було використано платформи онлайн-навчання, телебачення та радіомовлення [128]:

\section{Австрія}

- BMBWF - вебсайт Міністерства освіти, науки та досліджень Австрії, призначений для надання допомоги студентам та викладачам за допомогою посилань, ресурсів та інформації щодо підтримки дистанційного навчання.

- Eduthek.at - ресурсний портал міністерства з навчальними матеріалами для початкової та середньої школи, відсортовані за темами;

- ORF-1-Freistunde - громадська телевізійна станція, яка транслює спеціальні освітні програми для учнів на всіх шкільних рівнях, зокрема документальні фільми, пояснювальні відеоролики, а також новини, спеціально розроблені для цільової аудиторії.

\section{Бельгія}

- Enseignement.be - онлайн-платформа Федерації Валлонія-Брюссель з педагогічними ресурсами для викладачів та студентів.

- e-classe.be - Онлайн-платформа Федерації Валлонія-Брюссель 3 педагогічними та освітніми ресурсами для вчителів.

- Klascement - Національна платформа Бельгії, що містить різноманітні ресурси для різних рівнів освіти починаючи від дошкільної до освіти дорослих.

- Y'a pas école, on revise! - освітня програма для учнів від 6 до 12 років, яка дає змогу надолужити упущення в математиці, французькій мові та природничих науках.

\section{Боснія і Герцеговина}

- e-Nastava - навчальна онлайн-платформа Сербської Республіки, яка забезпечує учнів та вчителів корисними матеріалами та онлайн-класами.

- Телеканали - онлайн-класи через телевізійні трансляції для молодших класів початкової школи.

\section{Болгарія}

- National Electronic Library for Teachers - електронна бібліотека для підтримки вчителів педагогічними матеріалами для онлайн-навчання.

- With BNT2 at school - Освітня телевізійна програма, розпочата каналом БНТ2 та Міністерством освіти. 


\section{Хорватія}

- Skola za ẑivot - платформа для дистанційного навчання з матеріалами, які поділено за класами і предметами.

- Skola za ẑivot - Телебачення - Міністерство науки і освіти Хорватії у співпраці з радіо та телебаченням пропонує заняття для учнів початкової школи; відеоуроки доступні як по інтернету, так і по телевізору.

\section{Kinp}

- Learn From Television - освітні телевізійні програми, що транслюються на телеканалі RIK2.

- Photodentro - онлайн-платформа з ресурсами для дистанційного навчання, яка пропонує матеріали з різних предметів.

- Schools.ac.cy - вебсайт, що підтримує вчителів у веброзробці та забезпечує доступ до навчальних матеріалів для всіх рівнів освіти.

\section{Чеська Республіка}

- Ucitelka - телевізійна програма, яка забезпечує уроки для початкових класів.

- Nadalku - вебсайт, заснований Міністерством освіти, що підтримує дистанційну освіту і містить покликання на інструменти онлайн-освіти, оновлену інформацію та приклади передової практики, а також досвід щодо дистанційної освіти.

\section{Данія}

- emu.dk - освітній портал Міністерства освіти, що підтримує вчителів цифровими ресурсами для викладання та навчання онлайн.

\section{Естонія}

Естонія відома в усьому світі тим, що використовує технологічні рішення у врядуванні країною, сектор освіти не є винятком. Основним інструментом Естонії для дистанційного навчання під час закриття школи $€$ наявна в країні платформа eKool («e-School»), на якій уже понад 290 000 активних користувачів серед батьків, вчителів та учнів.

- Education-nation - Міністерство освіти не створило офіційної платформи, однак рекомендує використовувати колекцію цифрових рішень, складену естонцями, яка називається Education-nation.

\section{Фінляндія}

- ОРН.fi - новий вебсайт Фінського національного агентства з питань освіти, який відповідає потребам учнів, викладачів та сімей під час спалаху коронавірусу. 
- OPH resources - збірник ресурсів та матеріалів для підтримки дистанційного навчання, наданий Фінським національним агентством освіти.

- Yleisradio - освітні програми, що транслюються через національне суспільне мовлення.

\section{Угорщина}

- Oktatas - зібрання ресурсів для онлайн-навчання, виданих Мiністерством освіти.

- Digitalis oktatas - головний державний телевізійний канал Угорщини (MTV), який транслює онлайн-класи з різних предметних областей, орієнтованих на учнів початкових та середніх шкіл; записи також доступні в інтернеті.

\section{Франція}

- Ma classe à la maison - віртуальні класи, які полегшують вчителям організацію дистанційного навчання; доступні через смартфони та комп'ютери.

- Maison Lumni - 52-хвилинна щоденна програма, присвячена учням віком від 8 до 12 років, створена у співпраці з Міністерством національної освіти, що транслюється на France 4, France 2 та France 5.

\section{Німеччина}

- Bayerischer Rundfunk: Schule daheim -Online lernen - база даних з навчальними відео, відсортованими за темами та узгодженими з баварською навчальною програмою. Ініціатива Bayerischer Rundfunk (Баварська служба мовлення).

- Bildungsserver Berlin-Brandenburg - вебсайт із рекомендованими онлайн-інструментами та матеріалами для підтримки дистанційного навчання.

- Bildungsserver Mecklenburg-Vorpommern - захищена інтернет-база даних та матеріалів для підтримки дистанційного навчання.

- Hamburger Bildungsserver - база даних з онлайн-інструментами та матеріалами для підтримки дистанційного навчання, відсортованих за темами.

- Hessischer Bildungsserver - база даних з онлайн-інструментами та матеріалами для підтримки дистанційного навчання, відсортованих за класами та предметами.

- Landesbildungsserver Baden-Württemberg - регулярно оновлювана база даних з матеріалами та рекомендаціями для дистанційного навчання, відсортованих за темами. 
- Landesmedienzentrum Baden-Württemberg - вебсайт з онлайн-матеріалами, вебсемінарами та інструментами для підтримки дистанційного навчання, зокрема онлайн-консультаціями для вчителів та батьків.

- Mebis- Landesmedienzentrum Bayern - онлайн-платформа з навчальними відео та онлайн-інструментами для підтримки дистанційного навчання.

- Niedersächsischer Bildungsserver - вебсайт із рекомендованими онлайн-інструментами та матеріалами для підтримки дистанційного навчання.

- Online Schule Saarland - захищена онлайн-платформа для вчителів і учнів, що включає інструменти для відеоконференцій, онлайн-матеріали, інтегровану електронну пошту, надає можливість завантаження, поширення та обміну документами тощо.

- Thüringer Schulportal - онлайн-платформа для вчителів з онлайн-інструментами та матеріалами для підтримки дистанційного навчання.

- Unterstützung für das Lehren und Lernen in der Corona-Krise - зібрання онлайн-інструментів та матеріалів для підтримки дистанційного навчання у Саксонії-Ангальт.

- Unterstützungsangebot für Lehrerinnen und Lehrer in Phasen des Distanzlernens - посібник для вчителів із підтримки дистанційного навчання, зокрема зібрання інструментів та матеріалів.

- weBBcloud - захищена онлайн-платформа для вчителів і учнів для завантаження, зберігання та обміну навчальними матеріалами у Бранденбурзі.

\section{Греція}

- Digital Educational Material - платформа, заснована Міністерством освіти, що містить ресурси за класами та предметами.

- Interactive School Books - онлайн-сховище книг для учнів та вчителів.

- Mathainoumestospiti - онлайн-платформа, створена Міністерством освіти для сприяння дистанційному навчанню.

- We learn at home - телепрограма, що транслюється на національному телебаченні, спрямована на учнів початкових класів.

\section{Гренландія}

- Iserasuaat - репозитарій змісту освітніх програм для учнів і вчителів початкової, середньої та професійної освіти. 


\section{Ісландія}

- Ministry of Education webpage - вебсторінка на сайті Міністерства освіти, присвячена закриттю шкіл через COVID-19, яка інформує і консультує батьків щодо навчання вдома та забезпечення безперервності навчання.

\section{Ірландія}

- edTV - TV - освітні програми, які транслюються на різних телеканалах.

- PDST - платформа з підтримки дистанційного навчання та зібрання ресурсів для вчителів для забезпечення безперервності навчання.

- Scoilnet - офіційний портал, що пропонує онлайн-ресурси для підтримки шкіл, вчителів, учнів і батьків під час дистанційного навчання.

\section{Італія}

- INDIRE webinars - платформа Національного інституту документування, інновацій та освіти (INDIRE), що забезпечує вебінари для вчителів щодо підтримки методологій та інструментів дистанційного навчання.

- RAI Scuola - програми з навчальним контентом, зокрема анімаційні серіали та шоу про мистецтво, музику, історію і науку, які пропонує Національне суспільне мовлення RAI у співпраці з Мiністерством освіти Італії.

\section{Латвія}

- LTV7 program - освітні програми, що транслюються для учнів початкового та середнього рівня з різних предметних областей.

- Skola2030 - онлайн-платформа, що містить ресурси з різних предметів і орієнтована на учнів початкової та середньої школи, зокрема спеціальної освіти.

- Tavaklase - освітній телеканал під назвою «Ваш клас», створений Міністерством освіти і науки та його партнерами.

\section{Литва}

- Naujienos - цифрова навчальна платформа з освітнім середовищем, методологічними матеріалами, навчальними посібниками та іншою шкільною інформацією. 
- Domiosios Pamokos - освітні програми, що пропонує Литовське національне радіо й телебачення; містять навчальний зміст та інтерактивні елементи з різних предметних областей.

\section{Люксембург}

- Education Portal - платформа з різних предметів із навчальними ресурсами для учнів.

- Kanner Doheem - платформа з ідеями для позакласних занять, які можна проводити вдома.

- Schouldoheem.lu - платформа з навчальним контентом, доступна школам, вчителям і учням.

\section{Мальта}

- Curriculum.gov.mt - цифрові ресурси Міністерства освіти для учнів від дошкільної освіти до середньої.

- TeleskolaAn - ініціатива Міністерства освіти та зайнятості, розроблена для пошуку учнями та батьками відповідних уроків, представлених у зручний для користувача спосіб для підтримки безперервності навчання вдома.

\section{Нідерланди}

- Lesopafstand - вебсайт, розроблений Kennisnet у співпраці з Miністерством освіти, культури і науки, що забезпечує ресурсами для безперервності навчання під час закриття шкіл.

\section{Норвегія}

- NRK Skole - освітній контент, що транслюється через громадський телеканал.

\section{Польща}

- Epodreczniki.pl - освітній портал Міністерства освіти з навчальними онлайн-ресурсами.

- Szkoła z - освітній контент, що транслюється на телеканалі TVP.

\section{Португалія}

- Apoio à Escolas - зібрання ресурсів для підтримки шкіл щодо методологій дистанційного навчання.

- Estudo em Casa - телевізійні уроки, які транслюються як доповнення до онлайн-інструментів для учнів, що здобувають базову освіту (від 1 до 9 класу). 


\section{Румунія}

- Educred - онлайн-платформа, заснована Міністерством освіти і досліджень, яка централізує різні типи безкоштовних цифрових ресурсів та корисну інформацію з метою підтримки вчителів у використанні нових технологій під час дистанційної навчальної діяльності з учнями.

- Manuale - спеціальна платформа з цифровою версією всіх шкільних підручників, затверджена Міністерством освіти і досліджень, безкоштовних для завантаження.

- Telescoala - уроки для учнів 8-12 класів з метою підготовки їх до майбутніх національних іспитів, які пропонує Міністерство освіти та досліджень у партнерстві з Румунським національним телебаченням TVR; уроки доступні через телебачення та онлайн (на Youtube, на сторінці програми у Facebook та на вебсайтах телеканалів).

\section{Іспанія}

- Aprendemos en Casa - телевізійні програми, доступні через канал ClanTV, орієнтовані на учнів від 6 до 16 років.

- Aprendo en Casa Online - платформа з освітніми ресурсами, інструментами та програмами, які доступні вчителям, учням і батькам.

- Educlan - онлайн-канал, що підтримується Міністерством освіти і надає освітні ресурси впродовж дистанційного навчання вдома.

- INTEF - педагогічні ресурси Міністерства освіти для підтримки дистанційного навчання.

- Procomún - колекція близько 100 тис. освітніх ресурсів і навчальних об'єктів у різних форматах, створена Міністерством освіти та науки Іспанії за участі освітньої спільноти.

\section{Швеція}

- Skolahemma - сайт, що підтримується Шведським національним агентством з питань освіти і пропонує матеріали для учнів та вчителів для ефективного впровадження дистанційного навчання під час пандемії.

\section{Швейцарія}

- Eduport.ch - офіційний вебсайт з інформацією, покликаннями та ресурсами для підтримки дистанційного навчання. 


\section{Великобританія}

- ВBC Bitesize - численні освітні ресурси Бі-Бі-Сі для підтримки навчання вдома.

- DfE Online Education Resources - перелік онлайн-освітніх ресурсів для учнів усіх вікових груп для підтримки навчання вдома, який пропонує Міністерство освіти.

Важливим складником дистанційного навчання в умовах COVID-19 стала пряма фінансова підтримка урядами малозабезпечених сімей та співпраця з батьками.

Отже, ефективна організація ефективного дистанційного навчання передбачає швидке реагування на нові реалії, адаптацію змісту освіти (національних/регіональних курикулумів, освітніх програм, посібників та підручників) до нових умов, запровадження додаткового фінансування, підтримку учнів із малозабезпечених сімей і дітей з особливими потребами, співробітництво з батьками, з приватними структурами, передусім із провайдерами інтернет-послуг та медіа.

Щоб забезпечити неперервність у навчанні та в освітній діяльності, на сьогодні розроблено широкий спектр навчальних матеріалів, доступних в інтернеті [124]:

- системи управління цифровим навчанням;

- системи, спеціально призначені для мобільних телефонів;

- системи з розширеною офлайн функціональністю;

- масові відкриті онлайн-курси (МООС);

- мобільні додатки для читання;

- платформи для спільної роботи, що підтримують відеозв'язок у режимі реального часу;

- інструменти для створення цифрового навчального контенту;

- ресурси для надання психологічної підтримки.

Наведений нижче перелік освітніх програм, платформ і ресурсів покликаний сприяти батькам, вчителям, школам і шкільним адміністраторам, щоб полегшити процес навчання учнів і забезпечити соціальну допомогу та взаємодію під час дистанційного навчання. Більшість цих інструментів безоплатні, доступні й підтримуються кількома мовами. Вони, як правило, мають широкий діапазон охоплення, потужну базу користувачів і підтвердження досягнутих результатів.

\section{Системи управління цифровим навчанням}

- Blackboard - ресурси та інструменти для передачі й надання якісного онлайн викладання і навчання. 
- CenturyTech - персоналізовані шляхи навчання з мікроуроками для усунення прогалин у знаннях, тренування і поліпшення довгострокової пам'яті.

- ClassDojo - додаток, що з'єднує вчителів, учнів і батьків для створення громадських класів.

- Edmodo - інструменти і ресурси для управління класом і віддаленого задіяння учнів.

- Edraak - онлайн-навчання арабської мови з ресурсами для школярів і вчителів.

- EkStep - відкрита навчальна платформа з набором навчальних ресурсів для підтримки навчання грамотності та лічби.

- Google Classroom -дає змогу класам підключатися, спілкуватися й організовувати навчання віддалено.

- Moodle - відкрита освітня платформа, керована спільнотами і підтримувана на глобальному рівні.

- Nafham - онлайн-платформа навчання арабської мови, на якій розміщуються навчальні відеоуроки, що відповідають навчальним програмам Єгипту і Сирії.

- Schoology - інструменти для підтримки викладання, навчання, визначення рівня, співпраці і оцінювання.

- Seesaw - програма, що дає можливість створювати спільні та загальні цифрові навчальні матеріали та ресурси.

- Skooler - інструменти для перетворення програмного забезпечення Microsoft Office на освітню платформу.

- Study Sapuri - онлайн-платформа навчання японської мови для учнів середніх шкіл.

\section{Системи, спеціально призначені для мобільних телефонів}

- Cell-Ed - орієнтована на учнів, заснована на навичках навчальна платформа з офлайн-опціями.

- Eneza Education - редакційні та навчальні матеріали для телефонів із базовими функціями.

- Funzi - мобільна навчальна служба, яка підтримує викладання і навчання для великих груп.

- KaiOS - програмне забезпечення, яке надає можливості смартфонів недорогим мобільним телефонам і дає змогу відкривати портали для можливостей навчання.

- Ubongo - додаток, що використовує розважальні матеріали, засоби масової інформації та інші види зв'язку мобільних пристроїв для надання локалізованого навчання африканським сім'ям за низьких витрат і масштабів. 
- Ustad Mobile - доступ та обмін освітнім контентом в офлайн-режимі.

\section{Системи з розширеною офлайн-функціональністю}

- Can not wait to Learn - ігрова технологія, що забезпечує якісну освіту для дітей, зокрема в конфліктних ситуаціях.

- Kolibri - навчальний додаток для підтримки загальної освіти.

- Rumie - інструменти і матеріали для навчання, що дають змогу навчатися упродовж життя недостатньо забезпеченим послугами спільнотам.

- Ustad Mobile - доступ і обмін освітніми матеріалами в офлайн-режимі.

\section{Масові відкриті онлайн-курси (МООС)}

- Alison - онлайн-курси від експертів.

- Coursera - онлайн-курси, що проводяться викладачами з визнаних університетів і компаній.

- EdX - онлайн-курси від провідних навчальних закладів.

- University of the People - онлайн-університет з відкритим доступом до вищої освіти.

- Icourses - курси китайської мови для студентів університетів.

- Future Learn - онлайн-курси, які дають студентам можливість учитися, розвивати професійні навички та спілкуватися з експертами.

- Canvas - безперервне навчання і професійний розвиток для педагогів.

Навчальні матеріали, спрямовані на самостійну роботу.

- Byju's - навчальний додаток із великими сховищами освітніх матеріалів, пристосованими до різних класів і рівнів навчання.

- Discovery Education - безплатні освітні ресурси й уроки про віруси і спалахи для різних рівнів.

- Geekie - вебплатформа португальською мовою, яка надає персоналізований освітній контент із використанням адаптивної технології навчання.

- Khan Academy - безкоштовні онлайн-курси, уроки і практичні завдання.

- KitKit School - навчальний комплект на основі планшета з комплексної навчальної програми, яка охоплює дітей молодшого віку і початкові рівні.

- LabXchange - створений і керований користувачами цифровий навчальний контент, що надається на онлайн-платформі, яка забезпечує освітній і дослідницький досвід. 
- Mindspark - адаптивна система онлайн-навчання, яка дає можливість студентам практикуватися і вивчати математику.

- Mosoteach - додаток китайською мовою для розміщення класів у хмарній системі.

- OneCourse - орієнтований на дітей додаток для навчання читання, письма та лічби.

- Quizlet - вивчення за картками та іграми для підтримки навчання з кількох предметів.

- Siyavula - математична й фізична освіта відповідно до навчальної програми Південної Африки.

- YouTube - величезний репозиторій освітніх відео і навчальних каналів.

\section{Мобільні додатки для читання}

- African Storybook - відкритий доступ до збірок оповідань африканськими мовами.

- Global Digital Library - цифрові збірки оповідань та інші матеріали для читання, легкодоступні з мобільних телефонів або комп'ютерів.

- Lezioni sul sofà - колекція книг італійською мовою для дітей, доповнена функціями для читання вголос, а також відеороликами про книги і мистецтво.

- StoryWeaver - цифрове сховище багатомовних оповідань для дітей.

- Worldreader - цифрові книги і історії, доступні з мобільних пристроїв, і функціональні для підтримки правил читання.

Платформи для спільної роботи, що підтримують відеозв'язок в режимі реального часу

- Dingtalk - комунікаційна платформа, що підтримує відеоконференції, управління завданнями і календарями, відстеження відвідуваності й обмін миттєвими повідомленнями.

- Lark - набір інструментів для спільної роботи, включаючи чат, календар, створення контенту і хмарне сховище.

- Hangouts Meet - відеодзвінки, інтегровані з іншими інструментами Google G-Suite.

- Teams - чат, зустрічі, дзвінки і спільна робота, інтегровані з програмним забезпеченням Microsoft Office.

- Skyре - відео та аудіодзвінки з функціями чату, повідомлень і спільної роботи.

- Zoom - хмарна платформа для відео і аудіоконференцій, спільної роботи, чатів і вебінарів. 


\section{Інструменти для створення цифрового навчального контенту}

- Thinglink - інструменти для створення інтерактивних зображень, відео та інших мультимедійних ресурсів.

- Buncee - програма, яка підтримує створення і спільне використання візуальних уявлень навчального контенту, включаючи уроки, насичені медіаконтентом, звіти, інформаційні бюлетені та презентації.

- EdPuzzle - програмне забезпечення для створення відеоуроків.

- Kaltura - інструменти управління і створення відео з опціями інтеграції різних систем управління навчанням.

- Nearpod - програмне забезпечення для створення уроків з інформативною й інтерактивної оцінною діяльністю.

- Pear Deck - програма, яка полегшує розробку привабливого навчального контенту з різними функціями інтеграції.

- Squigl - платформа для створення контенту, яка перетворює мову або текст в анімовані відеоролики.

Ресурси для надання психологічної підтримки

\section{Ресурси для надання соціально-психологічної підтримки}

- Настанови Міжвідомчого постійного комітету при ООН щодо соціально-психологічної підтримки населення в умовах надзвичайної ситуації.

- Настанови ВООЗ щодо психічного здоров'я та соціально-психологічної підтримки населення в умовах спалаху COVID-19.

- Настанови ЮНІСЕФ щодо того, як вчителі повинні розмовляти 3 дітьми про COVID-19.

- Настанови ЮНІСЕФ щодо того, як батьки й опікуни можуть говорити з дітьми про COVID-19.

Отже, для забезпечення неперервності освіти світовою освітянською спільнотою застосовуюється широкий спектр різноманітних онлайн-інструментів та ресурсів (також можна використовувати в режимі офлайн) в рамках дистанційного навчання, які виконують різні функції, зокрема з'єднують вчителів та учнів, що знаходяться в різних локаціях; надають доступ до інформації та середовищ, зазвичай недоступних для кожного вдома чи освітньої установи; підтримують неперервний професійний розвиток освітян у гнучкій формі. 


\section{РОЗДІЛ 3}

\section{ОРГАНІЗАЦІЯ ДИСТАНЦІЙНОГО НАВЧАННЯ У ПОЧАТКОВІЙ ШКОЛІ}

Карантин - це серйозний виклик для початкової школи, на який довелось швидко реагувати й вчасно організувати підтримку учнів у навчанні. Складність вирішення питання пов'язана з багатьма чинниками, 3-поміж яких суттєвими вчителі називають такі:

- брак досвіду користування освітніми онлайновими ресурсами для проведення занять;

- проблеми з технічним забезпеченням діяльності у форматі онлайн (відсутність стабільного інтернет-з'єднання, незабезпеченість учнів технічними засобами тощо);

- складності організаційного плану (обмеження часу спілкування чинними гігієнічними нормами, недостатня відповідальність батьків у приєднанні дітей до дистанційних уроків, складності в організації зворотного зв'язку тощо);

- недостатнє дидактико-методичне забезпечення дистанційної форми роботи та інші.

Однак найвпливовішими є особистісні чинники, зумовлені віковими особливостями учнів молодшого шкільного віку щодо сприймання і засвоєння навчальної інформації, станом розвитку уваги та саморегуляції. Зазначені об'єктивні та суб'єктивні обставини привели до таких висновків і можливих шляхів вирішення проблем.

1. Дистанційне навчання засвідчило як сильні, так і слабкі сторони початкової школи. Особливо чітко простежувалось значення формування в учнів молодшого шкільного віку уміння вчитися як першооснови роботи в режимі онлайн.

Можливе рішення: внести, за можливості, корективи до навчально-методичних засобів (посібників, підручників тощо), де більшою мірою має акцентуватися увага на побудові методичного апарату, що передбачає використання форм організації навчання, необхідних для формування в учнів уміння вчитися та спільних для всіх компетентностей умінь. 
2. У режимі дистанційного навчання не спрацьовує організація діяльності на уроці, як це відбувається у звичних умовах. Навчальний матеріал не може розгортатися в часі за звичного підходу.

Можливе рішення: необхідно визначити пріоритети для кожного уроку. У змістових блоках, які забезпечують вивчення тем навчального курсу чи предмета, виділяти прийнятними для початкової школи засобами (наприклад, графічними) центральні питання, достатні для розуміння учнями матеріалу.

3. Запроваджувати дистанційне навчання в 1 і 2 класах, на думку вчителів, передчасно. У дітей не сформовані загальнонавчальні уміння і навички.

Можливе рішення: зустрічі онлайн використовувати для спілкування на загальні теми, зокрема для налаштовування на роботу. Завдання пропонувати учням невеличкими блоками. Створювати відеозаписи для коротких пояснень найважливіших питань теми.

4. Діти надто втомлюються, якщо проводити відеоуроки за розкладом у звичному режимі.

Можливе рішення: відеоуроки мають бути дозованими - не більше 15 хвилин, з тривалими перервами - щонайменше 20 хвилин без використання електронних пристроїв.

5. Діти молодшого шкільного віку не готові до самоорганізації, часто відволікаються; вчитель не може скеровувати дії дітей, як це доступно в умовах очної форми навчання.

Можливе рішення: розробити алгоритми/інструкції для організації роботи дітей в дистанційному режимі, залучаючи дорослих членів родини.

6. Низька мотивація учнів до роботи, діти часто втрачають орієнтацію в ході уроку.

Можливе рішення: розробити систему стимулів/відзнак за аналогом гейміфікованих занять.

7. До певної міри нівелюється основний принцип навчання - комунікативний, оскільки складно організувати такі види роботи як розігрування діалогу, інсценування; доповнення, взаємоперевірка, рецензування й оцінювання відповідей інших дітей у класі, роботу в парах тощо.

Можливе рішення: проводити дистанційні уроки, поділивши клас на групи (необхідно врахувати додаткове навантаження на вчителів).

8. Не всі вчителі мають можливості проводити уроки в дистанційному форматі. 
Можливе рішення: створити банк відеозаписів фрагментів уроків, що має бути складником кожного навчально-методичного комплексу.

9. Вчителі не мають належної підготовки до роботи з електронними платформами і сервісами.

Можливе рішення: запровадити в системі післядипломної підготовки вчителів тематичні вебінари-практикуми з питань дистанційного навчання.

10. Активне залучення (іноді - втручання) батьків до процесу навчання часто негативно позначається на таких аспектах як можливість дитини працювати самостійно, на організації власного навчального середовища, у виявленні відповідальності і навичок самоконтролю.

Можливе рішення: розробити інструктажі для батьків.

Науковці відділу початкової освіти імені О. Я. Савченко Інституту педагогіки НАПН України для підтримки учителів і учнів в умовах дистанційного навчання запропонували низку навчальних і методичних матеріалів. Це зокрема система робіт з української мови й читання, математики, курсу «Я досліджую світ», створені Оксаною Вашуленко, Оксаною Петрук, Валентиною Мартиненко, Оксаною Онопрієнко, Наталією Листопад, Іриною Андрусенко для забезпечення оперативного контролю навчальних досягнень учнів, у тому числі - формувального оцінювання результатів засвоєння змісту навчання. Всі вони розміщені у групі відділу на фейсбуці [7].

Для учнів 1-4 класів, які навчаються математики за навчально-методичним комплектом Світлани Скворцової і Оксани Онопрієнко, вчителі Юлія Спірідонова, Ганна Заставська, Людмила Крилова за консультування авторів підготували на основі сервісу Liveworksheets інтерактивні аркуші для опрацювання навчального матеріалу на онлайн-уроках і самостійно. Інтерактивні робочі сторінки розташовано в групі «Математика. Ранок. Пілот» на фейсбуку [53]. На сторінці цієї групи розміщено також серію відеоуроків математики, проведених учителями Анною Заставською, Мариною Кисіль, Наталією Червотокою, Аллою Дейнегою, Катериною Дитинюк. Більше уроків розміщено на ютуб-каналі видавництва «Ранок» [30].

Низку анімаційних уроків математики для 3 класу за навчальним комплектом Наталії Листопад розміщено на авторській сторінці «Вивчаємо математику разом з Наталією Листопад» на фейсбуці [6], а також на ютуб-каналі «НУШ Дистанційні уроки Літвінцева Наталя» [35]. 
Матеріали, які можна використовувати для дистанційної роботи з читання за підручником Оксани Вашуленко, розміщено в групі на фейсбуку «Вчимо вдумливо читати і розуміти прочитане» [10].

Карантин і викликана ним криза призвели не лише до змін в організації діяльності вчителів, а й вплинули на результати їхньої роботи. Після вимушеного переривання систематизованого навчального процесу, викликаного пандемією, постає проблема невизначеності щодо готовності учнів продовжувати запроєктоване раніше навчання. 3 огляду на це необхідно діагностувати стан засвоєння учнями змісту навчання у попередньому класі, що дасть можливість забезпечити оптимальні умови для організації планомірного освітнього процесу. Інструментом, який доцільно використовувати в подібних ситуаціях, $є$ педагогічне діагностування так званих залишкових результатів навчання. 3 цією метою науковці Оксана Онопрієнко, Оксана Петрук, Ірина Андрусенко розробили систему діагностувальних завдань за трьома модулями, пов'язаними з вивченням української мови й читання, математики, курсу «Я досліджую світ». Окреслюючи результати навчання української мови, розробниця модуля Оксана Петрук акцентувала пріоритетність розвитку учнів засобами різних видів мовленнєвої діяльності, визначених нормативними документами, Державним стандартом і типовою освітньою програмою. Саме тому діагностування націлювалось передусім на перевірку сформованості в учнів умінь з усіх видів мовленнєвої діяльності з одночасним урахуванням логічної послідовності, лексичної і граматичної правильності мовленнєвих висловлювань, які і $є$ показниками практичного застосування опанованих знань з мови. Другий модуль, розроблений Оксаною Онопрієнко, забезпечив дослідження навчальності учнів 3 математики. Він вдовольнявся переважно базовим змістом, пов'язаним із функціональними знаннями, вміннями та навичками, які мали б увійти до навчального досвіду учнів на попередньому етапі навчання. Це той обшир змісту, який остаточно формувався в попередній рік вивчення предмета й активно мав би використовуватись для подальшого розвитку математичної діяльності. За орієнтири освітніх результатів засвоєння змісту інтегрованого курсу «Я досліджую світ» розробниця модуля Ірина Андрусенко вибрала нормативні вимоги, визначені Державним стандартом і типовою освітньою програмою, які увійшли до інтегрованого курсу. Діагностувальні завдання передбачали виявлення учнями досвіду діяльності дослідницького спрямування; вони відображали очікувані результати навчання, 
виражені знаннями, уміннями й навичками. Систему цих робіт розміщено в електронній бібліотеці НАПН України [21]. Технологію моделювання діагностувальних завдань і організаційні особливості їх проведення висвітлено в монографії Оксани Онопрієнко “Дидактико-методичні засади контролю й оцінювання навчальних досягнень молодших школярів» [61].

Умови дистанційного навчання вплинули на зміст самоосвітньої діяльності вчителів початкової школи. Наразі до кола професійних навичок входить здатність педагогів працювати з різноманітними електронними сервісами. 3 метою ознайомлення учителів із найбільш прийнятними для початкової школи онлайн-сервісами Світлана Скворцова і Тетяна Бріцкан розробили дистанційний курс «Інтернет-ресурси для створення математичного навчання та ігрового змісту для молодших школярів». Опанування змісту курсу шляхом перегляду вебінарів дасть можливість учителям організувати дистанційне навчання математики, зокрема це: послуги для створення віртуального класу та його наповнення інтерактивними вправами й іншим навчальним контентом (LearningApps, Google Classroom, Classtime, Classdojo), послуги з організації дистанційного уроку (Padlet) та послуги з проведення онлайн-уроку у формі конференції (Zoom). Курс складається 3 п'яти модулів, кожен із яких присвячений окремому інтернет-ресурсу. На конкретних прикладах під час реалізації кожного модуля розглядаються можливості використання певних шаблонів для створення завдань та інформаційних повідомлень, пов'язаних із окремими видами математичних завдань початкового курсу математики; ресурси для реалізації кожного з етапів уроку математики в початковій школі. Відеозаписи вебінарів розміщено на платформі Zmist.op.ua [28]. 


\section{РОЗДІЛ 4}

\section{ОРГАНІЗАЦІЯ ДИСТАНЦІЙНОГО НАВЧАННЯ В ЗАКЛАДАХ СЕРЕДНЬОЇ ОСВІТИ II ТА III СТУПЕНІВ}

\section{1. ОСОБЛИВОСТІ ДИСТАНЦІЙНОГО НАВЧАННЯ ПРЕДМЕТІВ МОВНО-ЛІТЕРАТУРНОЇ ГАЛУЗІ}

\subsection{1. Особливості дистанційного навчання української мови}

3 метою визначення стану готовності вчителів до організації дистанційного навчання, виявлення проблем, що виникали в їхній роботі, співробітники відділу навчання української мови та літератури (сектор мови) здійснили опитування вчителів, учнівства, батьків за допомогою гугл-сервісів упродовж 20-27 травня 2020 року. В опитуванні взяли участь 1100 респондентів, із них - 68 учителів української мови і літератури, 664 учні, 368 батьків.

У процесі анкетування встановлено, що вчителі, які брали участь в опитуванні, мають стаж:

- понад 20 років - 75\%;

- 15-20 років - $13,2 \%$;

- 11-15 років - 8,8\%;

- 6-10 років - 2,9\%

97,1\% респондентів працюють у міських школах, 2,9\% - у сільських. 30,9\% учителів уже мали досвід організації дистанційного навчання; $69,1 \%$ такого досвіду не мали.

Під час анкетування з'ясовано, що до переваг дистанційного навчання вчителі відносять можливість виконувати завдання в зручний для учнів час (30,9\%), можливість застосовувати допоміжні джерела $(29,4 \%)$, збільшення питомої ваги самостійної роботи (27,9\%), необмеженість часу для виконання завдань $(11,8 \%$.). Результати анкетування уможли- 
влюють висновок щодо необхідності пошуку шляхів підвищення ефективності самостійної роботи учнів.

До недоліків дистанційного навчання вчителі відносять такі: послаблення безпосереднього контакту з учнями (73,5 \%), зниження ефективності навчання через слабкий вплив педагога $(38,2 \%) ;$ брак технічних засобів навчання $(29,4 \%)$. Найбільші труднощі у вчителів викликали: організація самостійної діяльності учнів $(67,6 \%)$, проведення уроків із синхронним застосуванням різних засобів зв'язку $(58,8 \%)$, перевірка рівня здобутих учнями знань $(42,6 \%)$, особливості оцінювання і контролю $(36,8 \%)$.

3 огляду на це завдання науковців і практиків полягає в тому, щоб використавши переваги дистанційного навчання, розробити ефективну методику навчання української мови в асинхронному режимі, а також допомогти вчителям мінімізувати недоліки дистанційного навчання.

Педагоги зазначили, що на вибір технологій і засобів організації дистанційного навчання найбільше вплинули такі чинники: рівень обізнаності з методами й засобами організації дистанційного навчання $(48,5 \%)$, мета й завдання навчального предмета $(29,4 \%)$, технічні можливості (22,1\%),

$57,4 \%$ опитаних визначили якість матеріалів, розміщених на освітніх онлайн-порталах як середню, 22,1\% - як задовільну, 20,6 \% - як високу.

Анкета передбачала визначення застосунків, які вчителі використовували для ознайомлення здобувачів освіти з новою навчальною інформацією, відпрацювання практичних умінь і навичок, контролю. 3-поміж ресурсів учителі називають такі: Zoom, Google Classrom, Viber, Мій клас, електронну пошту, Сайт «НаУрок» та ін.

На запитання «Яких матеріалів Вам бракувало під час дистанційного навчання?» 38,2 \% респондентів зазначили, що їм бракувало завдань для самостійної роботи, 33,8\% - електронного підручника, $14,7 \%$ тестів; 2,9\% - вистачало всього.

95,6\% погодилися з думкою, що потрібно розробити онлайн-платформу, зміст якої зможе сприяти реалізації мети чинної програми з української мови для 10-11 класів.

Цікавими виявилися відповіді учнів, які намагалися оцінити ефективність дистанційного навчання. 664 учні були розподілені таким чином: 5 клас - 15,7\%, 6 клас - 14,8\%, 7 клас - 13,4\%, 8 клас - 14,3\%, 9 клас 16,9\%, 10 клас - 15,7\%, 11 клас - 9,3\%.

Як свідчать результати анкетування, тільки 15,8\% учнів мали досвід дистанційного навчання. 
На запитання «Чи сподобалося вам дистанційне навчання?» 38\% відповіли: «швидше ні, ніж так»; 30,3\% - «швидше так, ніж ні», 28,2\% «складно відповісти».

3-поміж переваг дистанційного навчання 43,5\% учнів назвали можливість виконувати завдання в зручний час; 33,3\% - можливість застосовувати різні джерела інформації; 16,9\% - те, що час для виконання завдань не обмежений; 0,2\% переваг не побачили.

3-поміж недоліків учні $(38,1 \%)$ назвали зниження ефективності навчання через недостатній контроль з боку вчителя; 30,1\% - послаблення контакту з однокласниками; 13,6\% - брак умінь використовувати технічні засоби для навчання.

Найважчим чинником під час дистанційного навчання для учнів став брак безпосереднього спілкування з учителем і однокласниками (44,6\%), на другому місці - планування часу $(24,8 \%)$, необхідність працювати самостійно (24,5\%).

В учнів виникали такі проблеми: важко самостійно засвоїти новий матеріал (67\%); багато завдань для виконання (67\%). Учні висловили побажання - давати менше завдань.

43,4\% респондентів бракувало онлайн-консультацій учителя, 38,6\% контролю з боку вчителя, 18,1 - електронного підручника.

71,5\% учнів відповіли, що під час карантину найчастіше виконували тестові завдання, 14\% - творчі, 5\% - давали усні відповіді на запитання вчителя.

Спілкування з учителем відбувалося за допомогою електронної пошти - 48,5\%, телефона - 24,1\%, діалогу на освітніх платформах - 19,7\%.

На думку учнів, ефективними й цікавими для них виявилися: самостійна робота - 38,3\%, ілюстровані онлайн-уроки - 27,4\%, телеуроки - 26,5\%.

На запитання «Чи хотіли 6 ви навчатися дистанційно?» 50\% відповіли, що швидше ні, ніж так, 26,1\% - швидше так, ніж ні, 23,7\% - складно відповісти.

Для отримання цілісної картини перебігу дистанційного навчання подамо результати відповіді батьків.

29,6\% батьків зазначили, що відчули переваги дистанційного навчання порівняно з уроками; 64,7\% - ні.

На думку батьків, найважчим для їхніх дітей виявилися: брак спілкування з учителем і однокласниками - 59,2\%, необхідність працювати самостійно - 23, 9\%, планування часу - 12,5\%.

52.7\% батьків вважають, що на ефективність дистанційного навчання впливає рівень сформованості в учнів умінь самоосвіти; 34,5\% - заці- 
кавлення учителів у розробленні якісних навчальних матеріалів; 6,5\% рівень підготовки вчителів.

Вивчення результатів анкетування зумовило пошук ефективних шляхів організації дистанційного навчання. 3 огляду на те що всі групи респондентів акцентували важливість самостійної роботи і невміння учнів ії планувати, зусилля співробітників відділу навчання української мови та літератури були спрямовані на розв'язання означеної проблеми.

Важливою проблемою, яку доводиться розв'язувати вчителям-словесникам під час організації дистанційного навчання, є підвищення мотивації учнів до навчання української мови.

Психологічні дослідження засвідчують, що центеніали можуть бути зосередженими лише 7-10 хвилин. Тому правильна мотивація учнів $\epsilon$ одним із чинників ефективності дистанційного навчання і не може обмежуватися відповідним етапом уроку.

3 огляду на зростання питомої ваги самостійної роботи учнів не всі види традиційної мотивації працюють ефективно. Під час формування позитивної мотивації завдання вчителя полягає в переведенні зовнішнього стимулювання в самовиховання внутрішньої мотивації учнів. Захоплення педагога своїм предметом має перерости в захоплення учнів. Важливо вміло поєднувати цілевизначення й мотивацію учіння. Визначення учнем своїх завдань сприяє мотивуванню його діяльності, створенню ситуацій успіху.

Вирішальну роль у дистанційному навчанні відіграє найстійкіша внутрішня (когнітивна) мотивація. Вона чи не найскладніша для учня. Адже далеко не кожен усвідомлює себе особистістю, своє місце в соціумі, не знає, які конкретні знання знадобляться йому в дорослому житті, щоб стати щасливим та успішним. За О. П. Арестовим, пізнавальною мотивацією переймаються 81\% користувачів інтернету. Завдяки їй учень здобуває життєво необхідні знання, усвідомлює, що саме вони дадуть змогу стати щасливою успішною людиною [4].

Педагог-предметник має переконати учня в суб'єктивній значущості навчання, пояснити, що може дати вивчення предмета для розвитку нахилів, здібностей, професійного самовизначення й опанування омріяної професії, органічного входження у трудовий колектив, задоволення творчих прагнень тощо. Усе це виробляє внутрішню самомотивацію, самостимулювання.

Пізнавальні мотиви проявляються насамперед у зацікавленні учнів змістом. Тому настільки важливо розвивати в учнів здатність знаходити в змісті нової теми мотивацію для їі активного вивчення й акцентувати 
актуальність, новизну, практичну значущість. Чим більше зовнішніх і внутрішніх чинників буде задіяно, тим швидше сформується якісна мотивація.

Важливу роль у становленні мотивації відіграє можливість управління пізнавальним процесом. Це спонукає учня не зчитувати готову суцільну інформацію з монітора чи з підручника, а шукати й знаходити найбільш значущу саме для нього, що стимулює до розширення знань, заохочує до співтворчості, пошуку.

Мотивація за дистанційного навчання спрямовується на активну діяльність учнів, що викликає позитивні емоції. Збільшення стимулів для прояву різних емоцій підвищує ефективність навчання. Високий емоційний тонус досягається завдяки проведенню конкурсів ерудитів, вікторин, розповідей про особистості, огляду цікавих подій, дискусій, систематичних відповідей на запитання, що цікавлять учнів тощо.

Додатковим мотиваційним стимулом є якісний зворотний зв'язок.

Отже, за дистанційної форми навчання підвищенню мотивації сприяють:

- зрозумілість навчальних завдань;

- доцільне структурування занять;

- адекватне навантаження і реалістичність вимог, які мають бути досить високими, але не надмірними;

- стимулювання зацікавленості учнів предметом;

- методично грамотно розроблені дистанційні курси;

- сприймання дитини як особистості з власними потребами й пріоритетами;

- налагодження ефективної взаємодії між педагогом і учнями через спільне обговорення питань, розв'язання проблем;

- компонування й подання навчального матеріалу у форматі, який стовідсотково зацікавить учнів (покликання на відеоуроки, тести, опитувальники на Google-диску тощо);

- чітке, зрозуміле формулювання завдань; їх значущість і внутрішня прийнятність; посильність (завдання мають бути не надто легкі й не дуже складні, що сприятиме виявленню мотиву досягнення співвідношення результату учня з його здібностями);

- використання цікавого наочного і максимально доступного матеріалу, що стимулюватиме учнів розширювати й збагачувати знання; наведення яскравих прикладів;

- проведення ілюстрованих онлайн-уроків, що стимулюватимуть учнів до співтворчості, пошуку, дослідницької діяльності;

- використання оригінальних презентацій; 
- застосування різних методів і прийомів активізації пізнавальної діяльності учнів (діалогових, ігрових, креативних, проблемних, дослідницьких та ін.); їх відповідність віковим особливостям учнів;

- використання системи методів, які активують мисленнєву й мовленнєву діяльність, зокрема розвивають критичне мислення;

- практикування творчих завдань;

- застосування інтерактивних форм організації навчальної діяльності;

- орієнтування учнів на успіх, фіксування на успіхах, заохочення, відзначення здобутків і успіхів; створення ситуацій успіху;

- високий емоційний тонус уроків;

- створення теплої, доброзичливої, довірливої, комфортної та безпечної атмосфери участі тощо.

Спостереження за освітнім процесом, бесіди з учителями-словесниками переконують, що в освітній практиці найбільш поширеними є такі вебресурси для дистанційного навчання:

- платформа Moodle (https://moodle.org/);

- платформа Google Classroom (https://classroom.google. com);

- Microsoft Teams

Дистанційні уроки можна проводити також за допомогою Microsoft Teams, Zoom (zoom.us/download), Google Meet, Skype тощо.

Для самостійної роботи учнів доцільно використовувати хмарні сховища (Dropbox, Google Drive, OneDrive та ін.). Службу OneDrive можна використовувати для зберігання різноманітних документів, відеофрагментів, фотографій та інших файлів у хмарі, надавати до них спільний доступ. Подібні можливості має і Google Drive [71].

Оскільки навчання дистанційно може здійснюватися в синхронному і асинхронному режимах, то, відповідно, зміст і характер вправ, методичне забезпечення їх виконання мають залежати від особливостей співпраці учня і вчителя в умовах цих двох режимів.

Синхронний режим, коли всі учасники освітнього процесу одночасно перебувають у вебсередовищі, передбачає співпрацю вчителя й учнів у реальному часі. Це може бути відео-, аудіозв'язок, спілкування в чаті. Перевагою синхрону є одночасний зворотний зв'язок, миттєве залучення учасників у визначений час. Зворотний зв'язок має бути постійним і своєчасним. Упродовж перебігу дистанційного уроку (сеансу в 20-30 хвилин) ефективним буде максимальне планування орієнтованих на взаємодію з учнями інтерактивних вправ. Активне використання інтерактивних вправ зумовлене потребою 
розвитку пізнавального потенціалу учнів, здатністю впливати на мотивацію, ціннісні орієнтири, інтереси й потреби, формування навичок самостійної навчальної діяльності.

Учителеві важливо підготувати такі вправи, які перевіряють розуміння матеріалу, щоб мати можливість налагодити пізнавальний процес, усунути можливі ризики й конструктивно вирішувати будь-які поточні питання для досягнення поставлених цілей кожного уроку.

Педагог упродовж виконання цих вправ має змогу залучити одночасно багатьох учнів до активного спілкування, обговорення їхніх освітніх здобутків, обміну коментарями і враженнями (коментовані вправи), створюючи сприятливе емоційне середовище й розкриваючи творчий потенціал всіх учасників дистанційного навчання. Застосування таких вправ дасть змогу учням установлювати, підтримувати, зберігати контакт, переконувати співрозмовника; забезпечить практичне спрямування навчання на вищому - комунікативному - рівні, виробить в учнів здатність реалізувати спонукальну, пізнавальну, емотивну, ціннісно-орієнтаційну функції спілкування.

Працюючи в асинхронному режимі (освітній процес здійснюється за зручним для вчителів та учнів графіком), учні одержують вказівки щодо терміну виконання вправ і самостійно виконують спеціальні завдання у власному темпі й у зручний для себе час. Це може відбуватися через електронне листування, телевізійні уроки, коли вчителі створюють блоги, сайти тощо. Важливо звертати увагу на те, що чим чіткішими будуть інструкції учителя й зрозуміло прописані ним алгоритми для самостійного опрацювання, тим ефективнішим буде освітній результат після виконаних вправ. Для роботи можна підготувати вправи у формі онлайнтестів з автоматичним зворотним зв'язком. Такий вид вправ дає змогу перевірити рівень запам'ятовування інформації, відтворення роботи 3 іншими ґаджетами.

Вправи для асинхронного опрацювання мають бути диференційовані, творчі. Результатом виконання вправ $є$ формування ключових і предметної компетентностей. Необхідно спонукати учнів установлювати власні цілі вивчення кожної теми й фіксувати внесок кожного учня в досягнення поставлених цілей, відстежуючи прогрес та зростання власних навчальних здобутків, заохочувати учнів до самостійних пошуків інформації з різних надійних джерел і творчої діяльності.

Окрім розроблених учителем вправ, учням доцільно надавати рекомендації щодо перегляду тематичних вебінарів, фрагментів або й цілих онлайн-курсів на доступних платформах дистанційного навчання. Для обміну інформацією можна організувати додаткові комунікаційні ка- 
нали, чати, групи, у яких учні матимуть змогу обговорювати власні знахідки, обмінюватися покликаннями на цікаві ресурси, ділитися оцінкою онлайнових джерел і враженнями після роботи з ними. Такий вид вправ створюватиме комфортну емоційну атмосферу для стимулювання й підтримування діалогу між учасниками груп [70].

Цифровий режим взаємодії надає змогу здійснювати диференційоване навчання. Кожен учень чи група учнів можуть отримати вправу чи спеціальне завдання, які відповідають їхньому рівню навчальних досягнень. Це сприятиме індивідуалізації навчання, піднесенню ефективності освітнього процесу.

За можливості варто надавати учням право вибору різних варіантів вправ для демонстрації опрацьованого матеріалу кожної теми. Можна запропонувати учням творчо використовувати вивчені мовні засоби, оперувати здобутою інформацією. Наприклад, скласти власні вправи, створити карту понять певної теми, передати інформацію в графічний спосіб тощо. Наприклад, під час вивчення теми «Написання іншомовних слів. Правило "дев'ятки» (10 клас) радимо запропонувати десятикласниками вдома переглянути відео з YouTube («Лайфхак українською. Вживання и/і в іншомовних словах» (https://www. youtube.com/watch?v=QxbXNYOWIHw або опрацювати методично адаптований науково-навчальний текст і/або презентацію. Після опрацювання навчального матеріалу доцільно доповнити його інформацією, якої, на думку учнів, бракує; самостійно дібрати приклади; перетворити сприйняту інформацію на графічний об'єкт; спрогнозувати ситуації, у яких можна використати засвоєне; виконати вправи для самоперевірки.

Співробітники відділу навчання української мови та літератури Інституту педагогіки НАПН України розробили вправи на платформі LearningApps, після виконання яких учні зможуть самостійно визначити свій рівень знань із теми. Наприклад [12]:

- Уставте пропущені букви в словах іншомовного походження https://learningapps.org/watch?v=p4pfgxpnj20

- Виберіть правильний варіант написання слів https://learningapps.org/watch?v=pbo0pchgt20

- Зберіть «правописний пазл» https://learningapps.org/watch?v=piex4tr3520).

- Перекладіть слова з англійської мови на українську https://learningapps.org/watch?v=pzzpohxnk20

- Розподіліть слова іншомовного походження відповідно до написання (https://learningapps.org/watch?v=p8gs4ipoa20 
Перевірку вивченого матеріалу доцільно здійснювати за допомогою ClassDojo (https://www.classdojo.com/uk-ua/signup/), Classtime (https:// www.classtime.com/uk/), LearningApps.org (LearningApps.org).

На окрему увагу заслуговує застосування довідкових медіаресурсів на уроках української мови. Зазначимо, що не завжди учні мають змогу скористатися електронними словниками й довідковою літературою під час уроку через обмежений доступ до інтернету. Крім того, певний час займатиме і пошук інформації та її відбір відповідно до навчального завдання. Тому ознайомлення з можливостями медіаресурсів доцільно передбачити у процесі самостійної роботи. Наприклад, під час опрацювання тем «Основні типи словників. Довідкові медіаресурси» можна запропонувати десятикласникам такі завдання: 1) створити відеопрезентацію словника; 2) скласти порівняльну таблицю словникових статей різних словників синонімів; 3) підготувати текст рекомендаційного характеру «Скористайся словником і...»; 4) скласти огляд довідкових медіаресурсів з культури мовлення; 5) написати анотацію до словника термінів (за вибраним профілем); 6) записати лайфхаки з культури мовлення для однокласників тощо. Розмістити виконані завдання учні можуть у Google Drive i OneDrive, створивши папки й надавши до них спільний доступ однокласникам і вчителеві для оцінювання підготовленого творчого продукту.

Досвід екстреного вимушеного переходу до умов дистанційного навчання дає підстави стверджувати, що у перспективі необхідно добирати такі вправи, щоб посилювати мотивацію учнів до процесу навчання в нових умовах, працювати над виробленням у них навичок саморегуляції, умінь критично мислити, працювати з різноджерельною інформацією.

Ефективними домашніми завданнями з української мови в умовах дистанційного навчання $€$ виконання інтерактивних вправ, створення або доповнення карт пам'яті, підготовка проєктів тощо. Важливими $\epsilon$ завдання, що передбачають підготовку учнів до сприймання нового матеріалу, спрямовані на застосування здобутих знань, формування предметної та ключових компетентностей.

\subsection{2. Особливості дистанційного навчання української літератури}

Сучасні технології забезпечують можливість учням і вчителям працювати в різних форматах, реалізовувати нові форми навчання української літератури, сприйнятні сучасними учнями. Запровадження дистанційного навчання української літератури як інноваційної форми організації освітнього процесу пройшло різні стадії свого становлення й утвердження. 
3 метою виявлення основних потреб, переваг і проблем дистанційного навчання української літератури у квітні 2020 р. було організовано опитування учнів та вчителів-словесників закладів загальної середньої освіти (зокрема й із експериментальних) із різних регіонів України. Для збору інформації було використано програмне забезпечення Google Форм, що входить до складу вебпакету Google Docs Editors [106]. В опитуванні взяли участь 117 учнів і 172 учителів-словесників. Відповіді вчителів засвідчили, що запровадження дистанційного навчання стало для більшості опитаних психологічним викликом, фактором виходу із зони комфорту, оскільки є педагоги, які мають низький рівень компетенції щодо використання сучасних інформаційно-комунікаційних технологій. Так, більшість респондентів відчули розгубленість (65,1%), значна частина - відчай $(10,5$ \%) та паніку (5,8 \%). Байдужими залишилися 6,4 \% респондентів. Лише 12,2 \% педагогів засвідчили, що запровадження дистанційного навчання стало стимулом для них оволодіти новими інформаційними технологіями та реалізувати їх на практиці. Отже, результати опитування дають можливість констатувати, що більшість учителів психологічно не адаптовані до роботи в новому навчально-пізнавальному мережевому середовищі. Результати опитування щодо визначення ефективних засобів організації дистанційного навчання показали незначні розходження у відсотковому відношенні між учителями (У) і школярами (Ш). Так, платформа «На урок» - 7,3 \% (Ш(47,9\%) $<\mathrm{V}(55,2 \%))$, платформа «Zoom» - 3,9 \% (Ш $(44,4 \%)<\mathrm{V}(48,3 \%))$, платформа «Classroom» - 25,6 \% (Ш(19,7 \%)<У(45,3 \%)). Найпопулярнішим месенджером для дистанційного навчання було названо «Viber»: школярі - 37,6 \%, учителі - 45,3 \%. Продуктивною формою організації дистанційного навчання як учителі $(34,9$ \%), так і учні $(25,6$ \%) визначили телеуроки.

Певна кількість респондентів (15,4 \% учнів і 10,5 \% учителів) зазначили, що змістове наповнення шкільних підручників, наявність у них QR-кодів значно полегшило опрацювання навчального матеріалу.

Найбільш зручним як для структурування, збереження та обміну файлами, так і для забезпечення контролю та автоматичного оцінювання результатів навчання вчителі визнали багатофункціональний хмарний сервіс «Google-диск» (12,6 \%).

Під час організації дистанційного навчання української літератури вчителі-словесники визначили найбільш ефективними онлайн тестування (70,8 \%), відеолекції (58,3 \%) та вебуроки (33,3 \%). 
72 \% опитаних переконані, що підручник української літератури частково спроможний задовольнити освітні потреби учнів в умовах дистанційного навчання, $20 \%$ - повністю, лише $8 \%$ - мінімально.

Розміщені в мережі «Facebook» дидактично-методичні матеріали наукових співробітників відділу навчання української мови та літератури Інституту педагогіки НАПН України використовували 58 \% учителів, $26 \%$ - інколи, $16 \%$ опитаних ними не скористалися.

Більшість учителів (61 \%) уважають, що дистанційне навчання не може замінити традиційного, однак 37,2 \% переконані в перспективності використання технологій дистанційного навчання, а 1,7\% впевнені у його безальтернативності.

Однією із причин недостатньо ефективної організації дистанційного навчання української літератури $€$ незадовільна матеріально-технічна база закладів загальної середньої освіти, незабезпеченість інтернетом або низька швидкість доступу до нього, платні умови доступу до програмових засобів, брак персональних комп'ютерів в учителів та учнів. Значна кількість учителів (66,9 \%) і учні (31,3 \%) вказують на необхідність створення безоплатних освітніх платформ.

Важливою проблемою дистанційної форми роботи вчителі визначили брак сучасного комп'ютерного забезпечення (52,3 \%), а учні - власні лінощі (25,9 \%). Лише 10,8 \% учителів визнали власне небажання змінювати традиційні підходи до організації освітнього процесу. Значна кількість респондентів (У - 32,6 \%, Ш - 23,5 \%) погодилися, що для поліпшення організації дистанційного навчання необхідно запровадити проведення нарад, конференцій, семінарів, тренінгів у режимі онлайн.

Важливим для удосконалення процесу дистанційного навчання учителі вважають організацію науково-методичного супроводу діяльності педагогів із використанням цифрових ресурсів (61\%). Більшість педагогів $(65,1 \%)$ дієвим чинником називають використання технологій онлайн-навчання під час класних уроків.

Серед опитаних школярів цей варіант організації навчальної діяльності отримав 56,8 \%, а 34,5 \% респондентів виявили бажання виконувати домашні завдання на освітніх платформах.

Загалом кількість прихильників дистанційного навчання 3-поміж учителів становить 39,5 \% опитаних, а серед учнів - 59 \%. Певна кількість учителів-словесників періодично використовували технології дистанційного навчання, зокрема в процесі організації роботи учнів над навчальними проєктами, практикуючи онлайн-тестування 
тощо, тому таким педагогам було нескладно адаптуватися до нових освітніх реалій.

Отже, результати емпіричного дослідження, проведеного в соціальній мережі «Facebook» сектором української літератури відділу навчання української мови та літератури Інституту педагогіки НАПН України, засвідчили вплив психоемоційних, організаційних, технічних, а також частково кваліфікаційно-професійних чинників на ефективність організації дистанційного навчання української літератури [107].

Попри значний досвід використання засобів інноваційних інформаційних технологій в освіті в цілому та в навчанні української літератури зокрема, активне створення освітніх платформ в інтернет-просторі, залишається актуальною проблема пошуку оптимальних форм застосування інформаційно-комунікаційних засобів, урахування їх дидактичних можливостей, а також використання різних інформаційних технологій, що відповідають викликам сучасної освіти. Важливим є розуміння того, як саме організувати дистанційне навчання літератури, щоб забезпечити творчий, діалогічний, ефективний освітній процес.

Проведене на початку 2020/2021 навчального року опитування вчителів-словесників, матеріали численних вебінарів і конференцій засвідчили, що серед учителів української літератури найпопулярнішими $є$ окремі засоби та інструменти дистанційного навчання, такі як онлайн-середовище G SUITE FOR EDUCATION, засоби асинхронної взаємодії Viber, електронна пошта, інструменти отримання результатів - сервіси Google, Wizer. mе та інші. Для організації синхронної взаємодії учасники освітнього процесу активно послуговуються Google Meet, Zoom, рідше - Cisco Webex, Microsoft Teams тощо. Апробованими й визнаними ефективними є інтерактивні дошки Trello, Padlet, Storyjumper, Jamboard, сервіси для створення хмари слів Mentimeter, Answergarden, тестів - Google forms, Classtime.

Змішана форма навчання зумовила удосконалення процесу літературної освіти через:

- підвищення мотивації учителів-словесників до опанування нових сервісів, технологій навчання;

- зростання рівня інформаційної грамотності вчителів, учнів і батьків;

- покращення технічного забезпечення кабінетів літератури;

- запровадження електронного журналу/щоденника/розкладу;

- використання гнучкого розкладу, елементів змішаного навчання та формувального оцінювання. 
Водночас засвідчено, що брак живого спілкування спричинив і ряд проблем у шкільній літературній освіті. В умовах різкого переходу до змішаної форми навчання процес літературної освіти потребує вдосконалення, а організація уроків різних типів - методичних розробок із застосуванням онлайн-інструментів і способів організації інтерактивної взаємодії на різних їх етапах.

Для забезпечення дистанційного навчання здобувачів освіти вчителі-словесники впродовж 2020 і 2021 рр. почали активно створювати власні вебресурси або використовувати інші вебресурси із зазначенням покликання на джерело використаної інформації.

Дистанційне навчання потребує дотримання норм і правил академічної доброчесності. Важливо, щоб про це пам'ятали як учні, які виконують завдання, так і вчителі, які оцінюють, а також використовують у підготовці до уроків матеріали своїх колег, методистів, науковців. Тож культуру академічної доброчесності треба систематично вибудовувати між учасниками освітнього процесу.

Важливо обов'язково надати учням рекомендації щодо використання ресурсів, алгоритму виконання завдань, особливостей контролю тощо.

Для онлайн-комунікацій доцільно використовувати відеоконференції, форуми, чати, блоги, електронну пошту, соціальні мережі, служби обміну миттєвими повідомленнями та мобільні застосунки, які дають можливість створювати закриті групи, спільноти, чати, вести обговорення тем, завдань, проблем, інформації.

Поширеними $€$ такі вебресурси для дистанційного навчання:

- платформа Moodle (https://moodle.org/);

- платформа Google Classroom (https://classroom.google. com);

- Microsoft Teams.

Ефективними для організації відеоконференцій є програми Microsoft Teams, Zoom (zoom.us/download), Google Meet, Skype тощо, які дають змогу організувати значну кількість учасників.

Допоможуть у дистанційному навчанні української літератури електронні ресурси «OpenTheatre», «\#Живі письменники», «Українська література в іменах», «Лайфхаки з української літератури» та вебінари, проведені науковими співробітниками відділу навчання української мови та літератури Інституту педагогіки НАПН України [89].

Теми шкільної програми з української літератури розкриваються на каналі МOH України https://www.youtube.com/c/MONUKRAINE, курсах платформ Prometheus https://prometheus.org.ua/, EdEra https://www. ed-era.com/. На сайті МОН України «Всеукраїнська школа онлайн» презентовані відеоуроки (https://bit. ly/2XT6BIA). 
Важливим етапом уроку є мотиваційний, від якого залежить ефективність будь-якого виду навчального процесу. Під час дистанційного навчання традиційний спосіб цього важливого етапу уроку втрачає свої орієнтири. Тому педагогу важливо створювати ситуацію успіху, не забувати про схвалення, заохочення, прогнозування позитиву.

Дистанційне навчання може здійснюватися у двох режимах: синхронному (коли всі учасники освітнього процесу одночасно перебувають у вебсередовищі) або асинхронному, коли освітній процес здійснюється як для вчителя, так і для учнів за зручним графіком. Саме останній режим позбавляє миттєвої взаємодії та зворотного зв'язку через повідомлення, тому копіювати в онлайн-режимі структуру класно-урочної системи не варто. Як засвідчує шкільна практика, важливо надавати перевагу інтерактивним методам і прийомам організації навчальної діяльності.

Готуючись до уроку української літератури в режимі онлайн, учителеві необхідно чітко передбачити достатню кількість часу для виконання учнями різних видів навчальної діяльності, тобто збалансовано поєднати завдання, виконання яких пов'язано із використанням як електронних ресурсів, так і підручника, робочого зошита.

Якщо дотримуватися таких рекомендацій, освітній процес на уроках української літератури в дистанційному форматі дасть результати і буде посильний для всіх його учасників.

Організаційно будь-який онлайн-урок, зокрема й української літератури, складається зі вступної частини, основної й прикінцевої, у яких використовується певний арсенал інструментів і відбувається чіткий розподіл часу. Необхідно враховувати, що тривалість онлайн-уроку відрізняється від традиційного, оскільки, згідно з вимогами Санітарного регламенту, безперервна тривалість навчальної діяльності з використанням технічних засобів упродовж навчального заняття повинна бути для учнів 5-7-х класів не більше ніж 20 хвилин, 8-9-х класів - 20-25 хвилин, а для учнів 10-11-х класів на 1-й годині занять до 30 хвилин, на 2-й годині - до 20 хвилин.

Під час організації вступної частини онлайн-уроків української літератури проводяться мотиваційні інтерактивні вправи: формулювання очікувань від уроку, укладання правил роботи на уроці, елементи сторітелінгу, асоціації. Зважаючи на особливості предмета «Українська література», має відбутися не лише педагогічна мотивація до вивчення теми, а й емоційно-естетична, яка забезпечується переглядом ілюстрацій, відео, прослуховуванням аудіозаписів, а також використанням власних медіапродуктів, створених за допомо- 
гою безкоштовних онлайн-сервісів - коміксів (Storyboardthat, Pixton. com, ToonDoo.com), хмар слів (Mentimeter, Answergarden), заповнення мотиваційних фреймів на онлайн-дошках.

Основна частина онлайн-уроків української літератури складається із міні-розповіді учителя (максимум 10 хвилин), яка зазвичай супроводжується комп'ютерною презентацією, та інтерактивного виконання різних видів навчальної діяльності, як у режимі реального часу, так і у віртуальному середовищі, самостійно, у групах.

Для уникнення перевантаження учнів через кожні 15 хвилин уроку, під час спаду розумової активності, використовуються вправи-енерджайзери, пов'язані з уроком тематично. Оскільки рухова активність під час онлайн-навчання значно знижена, учні швидше втомлюються, використовуються стимулювальні головоломки на основі візуальних засобів на тему уроку української літератури, а також руханки для верхньої частини тіла, які можуть супроводжуватись художньою декламацією віршів, скоромовок.

Оскільки в основі уроку української літератури має бути робота з художнім твором, його читання й інтерпретація, то інтерактивні вправи в основній частині застосовуються з метою розвитку умінь учнів сприймати, розуміти й критично оцінювати художні твори. 3 метою оптимізації змісту уроку й раціонального розподілу часу використовується робота в групах, яка організовується за допомогою залів Zoom, виконується письмово на онлайн-дошках Padlet, Jamboard з використанням технологій розвитку критичного мислення "Шість капелюхів мислення», «SWOT-aналіз», «Fischbein» тощо та, як правило, завершується колективним брейнстормінгом про актуальність порушених у художньому творі проблем, його ідейний зміст.

У 9-11 класах ефективним є проведення онлайн-уроків української літератури у формі «перевернутого навчання», коли учні самостійно читають художні твори, виконують випереджувальні навчальні завдання, розміщені на онлайн-платформах (зокрема, Google Classroom), а під час уроків мають більше часу для виконання інтерактивних завдань, вікторин (за допомогою онлайн-сервісів Kahoot, Playbuzz, Swiper тощо).

Прикінцева частина онлайн-уроків української літератури передбачає інтерактивне підбиття підсумків, виконання навчальних завдань на узагальнення вивченого, отримання фідбеку про урок за допомогою вправ «Діаграма настрою», використання сервісів Mentimeter, Answergarden. Ефективним прийомом на підсумковому етапі уроку $\epsilon$ не лише запитання вчителя, а й формулювання запитань «ланцюжком» за прочитаним художнім текстом. 
На підсумковому етапі (етап рефрлексії) учні заповнюють «Стіну вражень» за прочитаним художнім твором на онлайн-дошці Padlet, отримують інформацію про виконання домашнього завдання. Продумане формулювання домашніх завдань, відведення оптимального часу на їх самостійне виконання $\epsilon$ важливим для ефективного дистанційного навчання української літератури. Їх контроль відбувається постійно. Для цього використовуються онлайн-сервіси Padlet, Miro, про внесення змін до яких у вигляді виконаних завдань приходять оперативні повідомлення вчителеві. За потреби він може коригувати їх у процесі роботи учнів або надсилати підказки чи впорядковувати. Для перевірки знань тексту художнього твору розробляються різнорівневі тести з однією правильною відповіддю, з декількома правильними відповідями, із відкритою текстовою або цифровою відповіддю, на встановлення послідовності, відповідності тощо.

Незамінним помічником учнів у вивченні української літератури $\epsilon$ шкільний підручник: вони перечитують матеріал теми виконують завдання. Це сприяє поглибленню засвоєння вивченої під час онлайн-уроку теми.

Ефективними домашніми завданнями з української літератури в умовах дистанційного навчання $€$ підготовка групових та індивідуальних проєктів, пов'язаних із інтеграцією літературних та ключових компетентностей, набутих під час вивчення теми, в особистий досвід учнів; заповнення заздалегідь підготовлених учителем фреймів на онлайн-сервісах; доповнення або колективне створення ментальних мап, інтерактивних плакатів тощо.

Систематизації усіх форм навчання української літератури в умовах дистанційного навчання сприяє затвердження формату проведення оцінювання учнів: тестові перевірки, письмові роботи, проєкти, відео- аудіопрезентації, а також здійснення обліку проведення навчальних занять через електронний класний журнал/щоденник, зокрема й на платформі АТОМС. Перевірку здобутих учнями знань і сформованих умінь варто здійснювати за допомогою ClassDojo (https://www.classdojo.com/uk-ua/ signup/), Classtime (https://www.classtime.com/uk/), LearningApps.org (LearningApps.org).

Отже, для забезпечення дистанційного навчання української літератури вчителеві необхідно продумано, методично обґрунтовано застосовувати інформаційно-комунікаційні засоби з урахуванням їх дидактичних можливостей. Незаперечними перевагами дистанційного навчання української літератури є його масовість, доступність, відкритість, інтерактивність, комфортність, оперативність, економічність тощо. 


\subsection{3. Особливості дистанційного навчання української мови в шко- лах з навчанням мовами національних меншин}

Запровадження карантину, спричиненого глобальною пандемією COVID-19, змусило системи освіти багатьох країн світу перейти на дистанційні форми навчання, зокрема в Україні. На жаль, система освіти, педагоги, батьки та учні переважно не були готові до такого виклику, попри те, що «Положення про дистанційне навчання», у якому визначені мета, зміст і шляхи його реалізації, було розроблено та затверджено МОН України ще у 2013 році. Однак, застаріле положення про дистанційне навчання, брак інформації про методику організації дистанційних уроків, інструменти для організації дистанційного навчання, електронні ресурси, платформи спричинили загальні проблеми в роботі багатьох учителів.

Попри те, що МОН України ініціювало Всеукраїнську школу онлайн, телевізійні й ютуб-уроки не охоплюють усіх предметів системи загальної середньої освіти, не розробленими залишилися курси з мов і літератур корінних народів і національних меншин та інших предметів гуманітарного циклу, пов'язаних з етнокультурним змістом освіти.

Упродовж періоду карантинних обмежень співробітники відділу навчання мов національних меншин та зарубіжної літератури здійснювали моніторинг стану вивчення предметів мовно-літературної галузі в закладах загальної середньої освіти з навчанням мовами національних меншин. Його метою було з'ясувати умови, проблеми й результати дистанційного навчання учнів початкових класів.

Питання, які стали предметом вивчення, стосувалися:

- доступу до мережі інтернет, способів комунікації, сервісів, освітніх платформ, які використовують учителі для організації навчання під час карантину;

- підходів до організації освітньої діяльності, формату перевірки та оцінювання результатів навчання учнів;

- ефективності засобів і технологій навчання;

- пропозицій щодо навчально-методичного забезпечення дистанційного навчання.

Упродовж карантину було проведено низку онлайн-інтерв'ю, опитувань освітян та експертне оцінювання практичної діяльності вчителів на різних етапах здійснення дистанційного навчання предметів мовно-літературної галузі.

У результаті було виявлено низку проблем, спричинених:

- неоднорідним соціально-економічним станом громадян, матеріально-технічним забезпеченням і часто відсутністю інтернет-покриття, особливо в сільській місцевості; 
- слабким рівнем володіння онлайн-технологіями та взагалі уміннями користуватися сучасним комп'ютерним і технічним обладнанням вчителями для створення та забезпечення дистанційного освітнього процесу;

- низьким рівнем умотивованості здобувачів освіти;

- нерозробленістю освітніх програм і навчально-методичного забезпечення з урахуванням можливостей дистанційних форм навчання;

- необізнаністю викладачів щодо наявності різноманітних методик використання інформаційних і телекомунікаційних освітніх ресурсів і платформ;

- непідготовленістю багатьох освітян до якісного онлайн-викладання та здобувачів освіти до онлайн-навчання;

- психологічними факторами тощо.

Так, у результаті опитування вчителів та батьків, співпраці з педагогами виявлено суттєві проблеми, спричинені специфікою доступу в Україні до інтернет-мережі. Учителів та учнів (батьків) як користувачів можна розподілити на такі категорії:

1. мають можливість для вибору інтернет-провайдера, підключення та користування інтернетом з високою швидкістю за помірною ціною (як правило, проживають у великих містах у багатоповерхових будинках, до яких проведено кабельний інтернет кількох провайдерів);

2. не мають вибору інтернет-провайдера, користуються інтернетом із нижчою швидкістю за вищою ціною (проживають у приватному секторі міст, селищах міського типу, селах);

3. мають проблеми з користуванням інтернетом через слабкість або відсутність сигналу мобільного інтернету, який є єдиним можливим варіантом (проживають у селах).

Учителі й батьки учнів, навіть ті, яких віднесено до 1-ї і 2-ї категорій, під час інтерв'ювань говорили, що періодично бачать на екрані комп'ютера попередження «ваше інтернет-з'єднання нестійке», та відчувають наслідки нестабільної швидкості інтернету. На думку інтерв'юерів, причиною цього $є$ велике навантаження на мережі провайдерів через карантин і вимушені дистанційне навчання та роботу.

Значна кількість учителів, яким потрібно проводити уроки дистанційно, мають власних дітей, які навчаються у школі, що спричинює недостатність гаджетів та ізольованих приміщень, неможливість надати допомогу під час дистанційного навчання власним дітям (у випадку виникнення технічних проблем). Через недостатній матеріальний рівень 
життя частина батьків не спроможна оплатити інтернет із потрібною для дистанційного навчання швидкістю або купити гаджети. Учні молодшого шкільного віку під час дистанційного навчання потребують допомоги батьків (підключення, контроль та ін.), однак не всі батьки можуть цим займатися, оскільки самі працюють.

Під час дослідження також з'ясувалося, що деякі вчителі не готові до дистанційного навчання, оскільки не володіють сучасними комп'ютерними технологіями, відповідно, потребують допомоги колег або часу для самостійного опанування технологіями дистанційного навчання. Відсутність або недостатність методичних навичок роботи в умовах дистанційного навчання часто призводить до нераціонального витрачання часу та перевантаження учнів.

Більшість учителів проводять уроки в сервісах Zoom, Google Classroom, ClassDojo, Microsoft Teams, «Мій клас», рідше - ведуть прямі ефіри на своїх каналах YouTube, створюють сторінки в соціальній мережі Facebook і використовують власні блоги. Учителі, як правило, використовують готові завдання, розміщені на різноманітних ресурсах (освітній портал «На урок», сайт «Всеосвіта» та інші). Деякі педагоги створюють завдання (тести) самостійно, часто використовуючи Google-форми.

Має місце і значне перевантаження вчителів, оскільки їм доводиться працювати на кількох платформах, складати завдання на одних сервіcax, а виставляти оцінки зовсім на інших, перевіряти завдання, які учні надсилають на електронну пошту або певний месенджер, найчастіше Viber, Skype, WattsApp, тобто переглядати чималу кількість фото різної якості, що негативно впливає на зір.

Важливим в освітньому процесі $€$ формувальне оцінювання навіть в умовах дистанційного чи змішаного навчання. Співробітники відділу Фідкевич О. Л., Богданець-Блоскаленко Н. І. підготували начально-методичний посібник для вчителів «Нова українська школа : теорія і практика формувального оцінювання у 3-4 класах закладів загальної середньої освіти». Київ : Генеза, 2020. (з грифом МОН). Посібник має електронну версію і вчителі вільно можуть послуговуватися його матеріалами, перейшовши за покликанням (https://bit.ly/3z9ZEws).

Також корисним для проведення формувального оцінювання у $1-2$ класах $€$ навчально-методичний посібник Фідкевич О. та Бакуліної Н. «Нова українська школа : теорія і практика формувального оцінювання у 1-2 класах». Київ : Генеза, 2019. (з грифом МОН). Електронну версію посібника можна завантажити за покликанням (https://bit.ly/2Sf8l8e).

Констатуємо, що за рік навчання в окреслених умовах рівень обізнаності вчителів щодо використання сучасних інструментів дистанційного 
навчання в освітній практиці, зокрема застосування сучасних інформаційних, телекомунікаційних і мультимедійних технологій навчання й інтеграції змісту освіти, значно зріс, ними накопичено цінний досвід проведення уроків у дистанційній або змішаній формах навчання, який, поза сумнівом, використовуватиметься в майбутньому.

Досвід учителів і рекомендації науковців Інституту педагогіки систематично висвітлюються на сторінках часопису «Український педагогічний журнал», у збірниках наукових праць, матеріалах конференцій.

Науковими співробітниками було розроблено рекомендації для вчителів початкових класів щодо організації дистанційного навчання (https://youtu.be/9_Od3ksYUg8), а також використання візуалізації вербальної інформації на уроках мовно-літературної галузі (https://sites. google.com/view/visualization-1-2class - сайт містить дидактичні матеріали для дистанційного та змішаного навчання. Ресурс апробується в опорних школах) та впровадження IKT-наочності на уроках української мови в закладах загальної середньої освіти з навчанням мовами національних меншин.

Загалом, у сучасній освітній практиці початкової школи засоби наочності зазнали значної трансформації за рахунок розвитку інформаційно-комунікаційних технологій та їх входження в освітній процес. Саме використання IКТ-наочності є провідним трендом у дистанційному та змішаному навчанні. Але, відповідно до даних проведеного нами дослідження, інтенсивність та ефективність використання IКТ-засобів на уроках української мови як державної можна значно підвищити.

Отже, вчителям були надані наступні рекомендації щодо застосування в освітньому процесі таких сучасних варіантів ІКТ-наочності, як

- скрайбінг - створення наочних образів безпосередньо у процесі викладу матеріалу - сприяє зацікавленості учнів, покращує сприйняття, усвідомлення та запам'ятовування інформації;

- сучасна схематизація (використання prezy та mindmaps) - розгляд предметів, явищ або, наприклад, основ граматики української мови в загальній спрощеній формі, що дає можливість цілісно сприйняти їх, визначити суттєві складові, полегшує процес аналізу та синтезу;

- інфографіка - графічний спосіб представлення інформації, спрямований на швидке й чітке усвідомлення складної інформації;

- інтерактивні зображення, книжки, журнали - електронна реалізація малюнків або друкованих видань з нелінійно упорядкованою інформацією, які містять інтерактивні елементи, зокрема завдання для дітей, опитування, ігри, відео- та аудіоконтент тощо, - мо- 
тивує учнів до вивчення матеріалу та активної участі в навчальній діяльності;

- хронологія та roadmap - графічне представлення на часовій шкалі 1) сюжетної лінії художнього твору, 2) алгоритму дій (при виконанні завдання або певної рутини), 3) цілей і результатів класного/ шкільного проекту тощо - сприяє формуванню компетентностей учнів, організації освітнього процесу;

- longread (зокрема, сторітеллінг) - формат подачі великого за обсягом тексту, розбитого на частини, за допомогою різних мультимедійних елементів: фотографій, відео, інфографіки та інших - актуальний варіант подачі об'ємного матеріалу для сучасних дітей (дозволяє врахувати феномен кліпового мислення молодших школярів та недостатню сформованість їх довільної уваги);

- буктрейлер - коротке відео за мотивами книги - спрямоване на зацікавлення учнів до читання та опрацювання художньої літератури;

- хмара слів - зображення, створене на основі групи слів, - варіант візуалізації технологій мозкової атаки чи асоціативного куща, спрямованих на розвиток критичного мислення учнів; тощо.

Окремо було закцентовано увагу на першочерговій актуальності розширення використання наочності в освітньому процесі від традиційної демонстрації дидактичних матеріалів до комплексної візуалізації навчальної інформації (яка $є$, насамперед, процесом створення наочного образу та передбачає активну суб'єкт-суб'єктну взаємодію вчителя та учнів), та впровадження інформаційно-комунікативних технологій уже в новому розширеному контексті, який має свою специфіку (діяльнісне спрямування, інтерактивний, ігровий аспекти тощо).

У межах науково-дослідної роботи за темою «Методика компетентнісно орієнтованого навчання української мови учнів початкових класів закладів загальної середньої освіти з навчанням мовами національних меншин» було створено онлайн-ресурс з методичними рекомендаціями щодо формування усного українського мовлення учнів $1-2$ класів закладів загальної середньої освіти з навчанням мовами національних меншин (https://sites.google.com/view/usne-movlennia).

Сайт містить дидактичні матеріали для дистанційного та змішаного навчання. Ресурс апробується в опорних школах.

Для допомоги організації дистанційного та змішаного навчання на уроках української мови як державної в початкових класах було розроблено дидактичний матеріал «Карта грамоти» (https://prezi.com/view/ Dgg6sJrSKM9iF7KBBSiV). 
Зазначений онлайн-ресурс стане у пригоді як при проведенні онлайн-уроків чи дистанційного навчання, так і протягом класичної очної форми занять. Учні можуть звернутися до нього при засвоєнні, узагальненні та систематизації знань з української мови.

Використання довідника сприяє формуванню предметної компетентності та візуальної грамотності на уроках, урізноманітнює освітній процес, підвищує інтерактивність у навчанні. Головними завданнями використання довідника в освітньому процесі $€$ :

- систематизація мовних знань з української мови та усвідомлення взаємозв' язків між його складовими;

- розвиток мислення та мовлення учнів;

- формування вміння роботи з візуалізаціями.

До довідника було запропоновано такі пояснення та рекомендації:

1. Суттєвою відмінністю запропонованого ресурсу $\epsilon$ нелінійна структура розміщення інформації. Заходячи в довідник, учень одразу цілісно бачить увесь матеріал та має можливість заглибитися в ту його частину, яка потрібна саме зараз. Це $\epsilon$ ґрунтовною основою систематизації мовних знань з української мови та усвідомлення взаємозв'язків між його складовими, але за умови, якщо вчитель приділятиме достатньо уваги цьому аспекту. Отже, доцільним $€$ регулярне використання цього ресурсу на уроках.

2. Увага учнів має бути спрямована на усвідомлення суті навчального матеріалу, а не на відтворення завченої інформації — як під час ознайомлення з новим матеріалом, його засвоєнням, так і на етапі узагальнення та систематизації знань.

3. Використання «Карти грамоти» як опори для побудови відповіді - це підґрунтя для розвитку зв'язного мовлення учнів, адже вони можуть сконцентруватися не на пригадуванні матеріалу, а на оформленні своєї думки в чітке та зрозуміле висловлювання.

4. Учні мають навчитися самостійно користуватися довідником, оскільки самостійне дослідження «Карти знань» сприяє розвитку їхнього мислення, а також формуванню свідомого ставлення до навчання та самоконтролю.

5. При формуванні вміння працювати з довідником доцільно ознайомити учнів з використаними в ньому візуальними структурами представлення інформації. Також регулярне використання довідника $€$ необхідною умовою формування навичок роботи учнів з сучасним візуальним контентом у контексті навчальної діяльності. 


\subsection{4. Особливості дистанційного навчання іноземних мов}

Для з'ясування особливостей дистанційного навчання іноземних мов у закладах загальної середньої освіти під час карантину співробітниками відділу навчання іноземних мов Інституту педагогіки НАПН України було проведено анкетування вчителів експериментальних навчальних закладів різних регіонів України. Як показали його результати, учителі, учні та їхні батьки виявилися не зовсім готовими до такої тривалої форми освіти взагалі та до дистанційного навчання і вивчення іноземної мови зокрема. Ураховуючи відсутність попереднього досвіду масштабного переходу на дистанційне навчання, педагогам знадобився деякий час для вивчення, аналізу та вибору технологій, методів і засобів дистанційної освіти. Найбільш готовими до дистанційного навчання усе-таки виявилася більшість учнів, проте не всі. Школярам було легше використовувати уже відомі їм платформи, з якими вони працювали раніше під час навчання до карантину.

Найважче було батькам учнів, які повинні були поєднувати виконання своєї професійної роботи в дистанційному режимі з хатніми обов'язками та допомогою дітям в організації їхнього навчання, зокрема з виконанням уроків. Опитані вчителі особливо відзначають батьків учнів початкової школи, без підтримки та допомоги яких педагоги не змогли б ефективно виконувати свою роботу, а діти засвоювати навчальний матеріал.

Під час дистанційного навчання в основному вчителі користувалися: платформою «Google Classroom» (94,3\%) для передачі інформації, перевірки робіт, проведення тестування й оцінювання учнів. На платформах «Skype» $(11,1 \%)$ і «ZOOM» $(44,4 \%)$ педагоги проводили онлайн-уроки, відеоконференції та індивідуальні консультації. Також використовувалися програми для тестування «quizizz.com» (22,2\%), освітні ресурси «ProfeDeEle» (11,1\%), «Aprenderespañol» (11,1\%), «Lingolia» (11,1\%), «VideoEle» (11,1\%). «ZOOM» $(45,5 \%)$ i «Skype» $(11,6 \%)$ виявилися зручними для пояснення нового матеріалу, контролю вимови, для вироблення навичок читання й аудіювання, для практики говоріння. Серед інших освітніх платформ названо: Express Digibooks (77,7\%), Viber (44,6\%), MyClass (43,8\%), To the lesson (33,3\%), Youtube (22,3\%), Liveworksheets $(11,1 \%)$. Використовувалися також відеоуроки офіційного телевізійного каналу МОН України і ТК «Рада».

Відповіді респондентів на запитання про онлайн-платформи і сервіси, які використовувалися ними у процесі дистанційного навчання іноземної мови, продемонстрували широкий спектр інструментів навчання (рис. 1). 


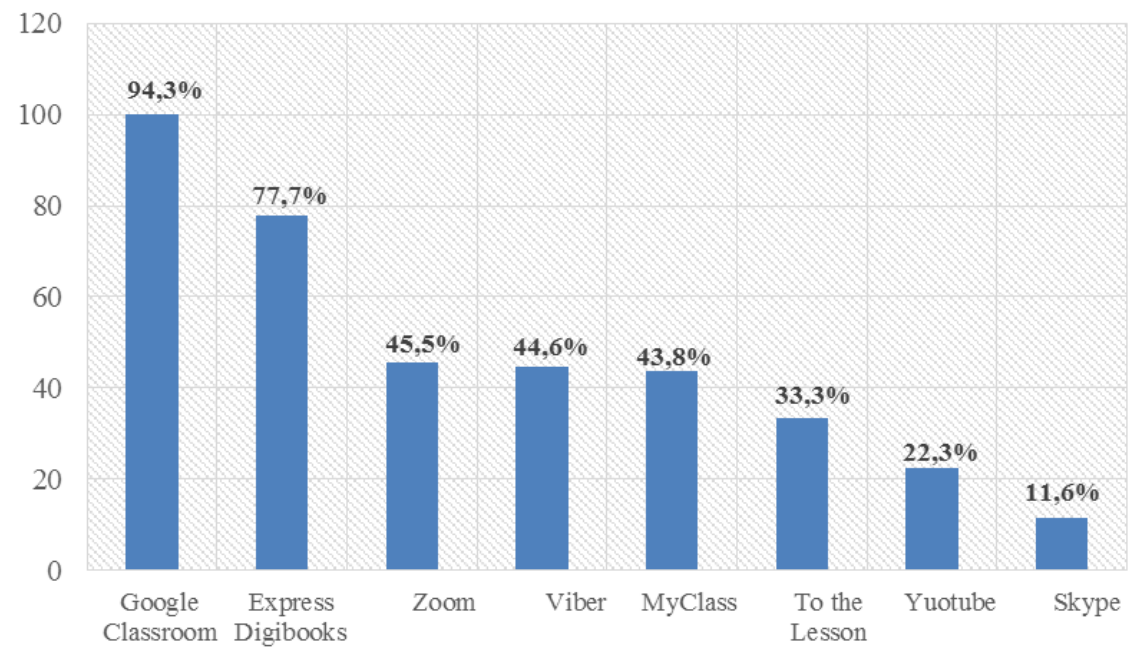

\section{Рис. 1. Онлайн-платформи і сервіси для дистанційного навчання іноземної мови}

Зокрема, платформа Google Classroom, яку найбільше вподобали вчителі іноземних мов $33 \mathrm{CO}$ (94,3\%), виявилася зручною та простою у використанні. Плюсами $€$ те, що всі завдання зібрано в одному місці, учні отримують нагадування про здачу домашніх завдань, учитель має можливість бачити всі оцінки учня за всі завдання та надавати зворотний зв'язок, вчасно повідомляти батьків про успіхи їхніх дітей. Учні можуть прикріплювати виконані завдання в різних форматах. До мінусів платформи педагоги віднесли ії перевантаження та зникнення файлів. Більшість опитаних учителів планує користуватися цією платформою і в наступному навчальному році.

У процесі дистанційного навчання використовувалися як синхронні засоби навчання (Zoom, Skype, Google Classroom, Viber відеозв'язок), так і асинхронні (електронна пошта, блоги, онлайн відеоуроки, матеріали для опрацювання, в тому числі у вигляді аудіо- та відеофайлів, на які діти записували свої відповіді та надсилали вчителю).

Основні методи дистанційного навчання, які були використані в роботі, - це бесіди, рольові ігри, дискусії, проєктні роботи, методи стимулювання і мотивації навчання, контролю й самоконтролю (зокрема письмового). У початковій школі найбільш ефективними виявились ті методи, що ґрунтуються на візуальній та слуховій основі; у середній та старшій школі - використання творчих завдань, проблемно-пошукова та проєктна робота, яка сприяє пізнавальній самостійності та креатив- 
ності учнів. До ефективних методів варто також віднести асинхронне та синхронне навчання з використанням аудіо- чи відеозв'язку, спілкування та консультації в чаті або листування, перегляд відеоуроків, виконання онлайн тестів і завдань.

У дистанційному навчанні іноземних мов здійснювалося поєднання онлайн, традиційного та індивідуального навчання. Використовувалися такі форми навчання: консультації (групові та індивідуальні), індивідуальні заняття, самостійна робота, проєктна робота, відеоконференції, онлайн-уроки, аудіозаписи. Проводилося онлайн-тестування, використовувалися онлайн-тренажери для вивчення граматики і лексики, фото-, відео- та аудіоматеріали з ҮouTube. Учителі мали можливість робити демонстрації екрану, одночасно спілкуватися з групою, проводити тестові завдання з моментальним результатом, працювати онлайн із підручником у форматі PDF із малюванням і помітками в ньому, підключатися онлайн до сайтів по тематиці уроку тощо. Зворотний зв'язок відбувався у формі спілкування через аудіоповідомлення та міні-проєкти.

Онлайн оцінювання здійснювалося (напівавтоматично й автоматично) переважно в «Google Classroom» (44,4\%), а також за допомогою електронної пошти (33,4\%), «Skype» (11,1\%) і «Viber» (22,2\%). Оцінювались усні та письмові роботи, надсилались аудіо- та відеофайли, виконувалися тести. При використанні Viber-зв'язку учні надсилали фото виконаних завдань, учитель оцінював і надавав рекомендації письмово або телефоном. Окремі педагоги виправляли помилки за допомогою програми «Paint», або у приватних повідомленнях. Говоріння дітей оцінювалося через усне онлайн-опитування; читання, аудіювання й письмо - через тести онлайн.

До найбільш поширених форм онлайн оцінювання віднесено: виконання тестових завдань, написання самостійних, контрольних і творчих робіт, заповнення таблиць, підготовка проєктів тощо.

Електронна пошта (email) виявилася тим інструментом навчання, за допомогою якого вчителі найчастіше забезпечували зворотний зв'язок 3 учнями. Інтернет надавав доступ до віддалених баз даних, інформаційно-довідкових систем, бібліотек з вивчення іноземних мов (електронні підручники, відеоролики, комп'ютерне тестування, контроль і самоконтроль знань) і можливість онлайн-спілкування (сучасні технології забезпечують управління екраном комп'ютера: створення схем і малюнків на відстані, передача фото- і рукописних матеріалів).

Для отримання учнями домашніх завдань з іноземних мов використовувалися різні інструменти (рис. 2). 


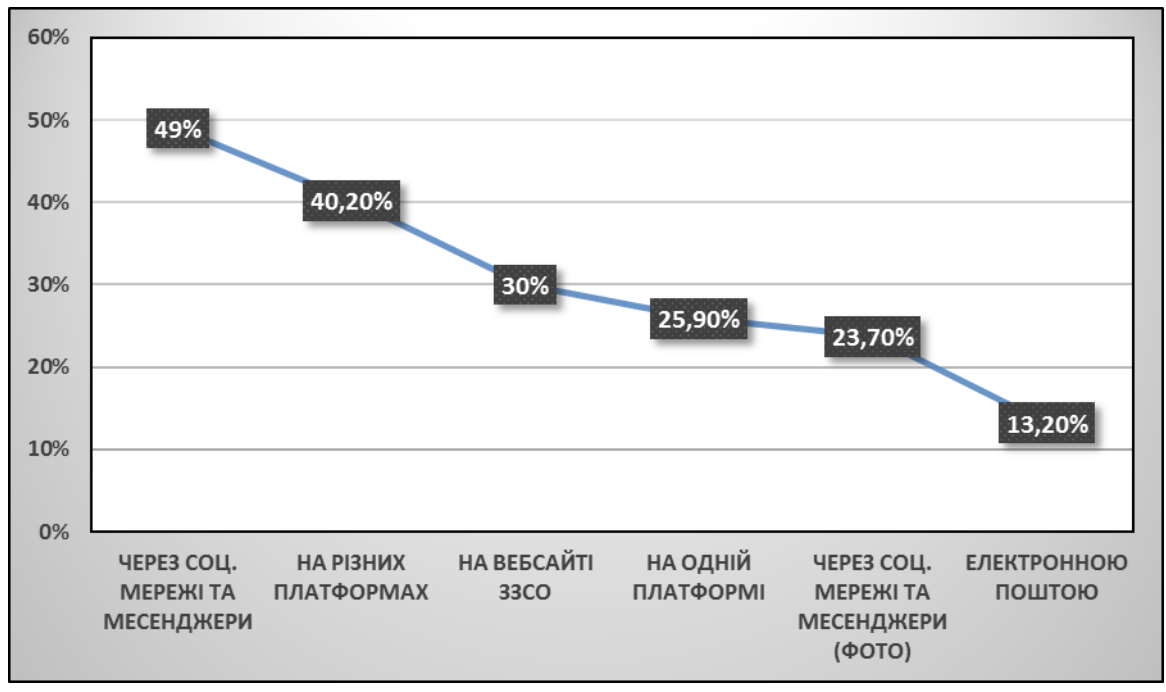

Рис. 2. Інструменти отримання учнями домашніх завдання онлайн

Як видно з рис. 2, найбільш популярними серед учителів у цьому виді роботи є соціальні мережі та менеджери. Разом із соціальними мережами та месенджерами (фото) вони складають $72,7 \%$. Незважаючи на популярність електронної пошти у повсякденному житті, відсоток її використання $(13,2 \%) \in$ найнижчим серед названих інструментів отримання домашніх завдань.

У зв'язку з продовженням епідемії навесні 2020 року учні не складали іспити. Онлайн оцінювання їхніх знань за весняний семестр виявилося складним завданням для вчителів, тому вони планували зробити це на початку нового навчального року. Тому складно сказати, яких успіхів досягли учні при дистанційному навчанні.

Лише ті випускники шкіл, які збиралися стати студентами закладів вищої освіти (3ВО), пройшли зовнішнє незалежне оцінювання (3НО) з іноземної мови, яке $\epsilon$ обов'язковим. Останнім часом 3НО стало основним інструментом відбору абітурієнтів до ЗВо України. Результати незалежного оцінювання з іноземних мов у 2020 році виявилися кращими, ніж у 2019 році.

Як видно з таблиці, випускники 33СО у 2020 році показали кращі результати, ніж у 2019 році, з усіх іноземних мов, незважаючи на те, що протягом трьох місяців вони вивчали іноземні мови дистанційно. Більше того, учні, які вивчали німецьку мову, виявилися краще підготовленими, ніж випускники $33 \mathrm{CO}$ з інших мов (різниця в показниках становить 9,2\% на користь 2020 року). Учні, які вивчали англійську та іспанську мови по- 
казали майже однакові результати (з різницею у 5,3\% і 5,4\%), а найнижчі показники виявилися з французької мови (різниця 4,5\%) (таблиця 4.1).

Таблиця 4.1

Відсоток учасників, які не змогли подолати поріг «склав/не склав»

\begin{tabular}{|c|c|c|c|c|}
\hline $\begin{array}{l}\text { № } \\
3 / n\end{array}$ & Мова & 2019 & 2020 & $\begin{array}{c}\text { Різниця } \\
\text { (2019 до 2020) }\end{array}$ \\
\hline 1. & Англійська & $12,7 \%$ & $7,4 \%$ & $-5.3 \%$ \\
\hline 2. & Німецька & $20,6 \%$ & $11,4 \%$ & $-9.2 \%$ \\
\hline 3. & Французька & $12,3 \%$ & $7,8 \%$ & $-4.5 \%$ \\
\hline 4. & Іспанська & $16,7 \%$ & $11,3 \%$ & $-5.4 \%$ \\
\hline
\end{tabular}

На думку респондентів, успіх дистанційного навчання іноземної мови було досягнуто насамперед за рахунок тісної співпраці адміністрацій шкіл/гімназій/ліцеїв з учителями, з одного боку, і налагодженням зв'язку між учителем, учнями та їхніми батьками, з іншого. Найважливішим $\epsilon$ те, що вдалося організувати онлайн-уроки. Дистанційне навчання дало можливість зробити пояснення нового матеріалу більш образним, яскравим, різноманітним. Учні краще його сприймали і мали можливість прослухати чи подивитися стільки разів, скільки потрібно для того, щоб зрозуміти. Використання на уроках презентацій з анімацією, ігрових елементів зумовило успіх у проведенні дистанційних уроків. Найефективнішим було навчання дітей початкової школи тому що батьки й учні 1-4 класів виявилися більш умотивованими та зацікавленими в навчанні.

Що стосується використання сервісів і платформ, то серед позитивів було названо: підтримку особистого контакту, безпосередність, відчуття прямого голосового та візуального контакту; при асинхронному навчанні - додатковий час на виконання завдань, незалежність відповіді учасників від місця та часу, комфортне спілкування в письмовій формі.

Із певних причин не вдалося в повній мірі залучити всіх учнів до дистанційного вивчення іноземної мови (відсутність технічних засобів у родинах і проблеми з Інтернетом, труднощі під час самостійного вивчення або виконання певних завдань тощо). Для більшості педагогів основна складність дистанційного навчання полягала в неможливості якісного контролю за засвоєнням учнями вивченого матеріалу. Основною проблемою для учнів, на думку педагогів, стало невміння керувати власним часом під час дистанційного навчання та самодисципліна. А найбільшим мінусом учителі вважають те, що діти проводили занадто багато часу перед екраном комп'ютера. Крім того, не всі батьки йшли на контакт із учителями. 
До недоліків синхронного дистанційного навчання педагоги віднесли: фрагментацію навчання - учні могли знаходитись у ситуаціях, що відволікали від занять; час спілкування був обмеженим, як і можливості при використанні якісних засобів на безоплатній основі; учні молодшого шкільного віку могли користуватися такими засобами переважно за допомогою батьків. Недоліками асинхронного навчання визначено: відсутність особистого контакту з учнем і вербального спілкування, зворотний зв'язок може бути відкладений.

Для того щоб дистанційне навчання стало органічним продовженням або доповненням до традиційного, на думку вчителів, потрібно здійснити ряд заходів, зокрема: 1) розробити загальнодержавну програму щодо впровадження засобів дистанційного навчання з доступним і широким функціоналом, де зможуть співпрацювати вчителі, батьки й учні; 2) створити національну електронну платформу для дистанційного та змішаного навчання; 3) розробити сучасне положення про дистанційне навчання; 4) розробити методичні рекомендації щодо організації, планування та структури онлайн-уроків з усіх навчальних предметів, у тому числі й іноземної мови; 5) забезпечити учасників навчального процесу швидкісним Інтернетом і сучасним технічним обладнанням у достатній кількості, що дасть можливість рівного та якісного доступу до надання й отримання освітніх послуг; 6) систематично проводити для вчителів семінари, тренінги, курси для одержання ними практичних навичок роботи з технологіями дистанційного навчання; 7) розглянути питання щодо розроблення електронних додатків до вітчизняних підручників, які 6 містили матеріали для використання в умовах форс-мажорних ситуацій.

Реалізація зазначених вище заходів дозволить уникнути труднощів в організації та проведенні дистанційного навчання учнів $33 \mathrm{CO}$ в разі виникнення форс-мажорних обставин у майбутньому. Ці заходи стосуються не лише навчання іноземної мови, а й інших шкільних предметів.

\section{2. МЕТОДИЧНА ПІДТРИМКА ВЧИТЕЛІВ ІСТОРІї, ОСНОВ ПРАВОЗНАВСТВА ТА ГРОМАДЯНСЬКОЇ ОСВІТИ В УМОВАХ ДИСТАНЦІЙНОГО НАВЧАННЯ}

В умовах пандемії, переходу на дистанційні та змішані форми навчання і роботи проблема вибору й використання інтерактивних електронних медіа ресурсів, зокрема соціальних мереж, стає надзвичайно актуальною. Однією з найбільших соціальних мереж, що приділяє значну увагу освіті, $\epsilon$ Facebook. Чимало освітніх закладів та наукових установ використовують можливості та засоби Facebook як віртуального майдан- 
чика для публікації новин, оприлюднення результатів діяльності, організації взаємодії з цільовою аудиторією тощо.

Дистанційне навчання в умовах пандемії стало світовим трендом і глобальним викликом освіти, що потребував швидкої адекватної відповіді, зокрема, української педагогічної спільноти, органів виконавчої влади та місцевого самоврядування, Міністерства освіти і науки України.

Для методичної підтримки вчителів історії, основ правознавства та громадянської освіти співробітниками відділу суспільствознавчої освіти були створені мережеві ресурси: сторінка відділу та група в соціальній мережі Фейсбук.

І. Сторінка в соціальній мережі Фейсбук «Відділ суспільствознавчої освіти Інституту педагогіки НАПН України».

Адреса сторінки: https://www.facebook.com/Відділ-суспільствознавчої-освіти-Інституту-педагогіки-НАПН-України-107552070892087

Сторінка створена 25 березня 2020 р. та підтримується співробітниками відділу суспільствознавчої освіти.

Цільова аудиторія: науковці, методисти, вчителі історії, правознавства та громадянської освіти, викладачі закладів післядипломної педагогічної освіти.

Мета створення ресурсу: ознайомлення педагогічної громадськості із діяльністю, дослідженнями та здобутками співробітників відділу суспільствознавчої освіти Інституту педагогіки НАПН України; використання можливостей соціальної мережі для обговорення актуальних проблем шкільної історичної, громадянської, правової освіти в Україні, проведення опитувань і анкетувань учителів, учнів, викладачів студентів; презентація освітніх заходів і подій, організаторами й учасниками котрих є співробітники відділу суспільствознавчої освіти.

Види викладених матеріалів:

- інформація про наукову та експериментальну діяльність відділу; проведені освітні та наукові заходи;

- анонс заходів, у тому числі й онлайн, організатором яких виступає відділ суспільствознавчої освіти;

- науково-методичні розробки, фрагменти методичних і навчальних посібників, підручники співробітників відділу та покликання на них в електронній бібліотеці НАПН України;

- науково-публіцистичні матеріали, проблеми для обговорення й дискутування в колі педагогічної спільноти;

- анкети для опитування вчителів та учнів із різної тематики (зокрема щодо: навчання в умовах карантину, інтегрованого навчання 
історії, дотримання культури академічної доброчесності в освітніх закладах, концентричного/лінійного викладання історії тощо);

- звіти (в тому числі фотозвіти) про освітні заходи і події за участю співробітників відділу суспільствознавчої освіти.

Статистика відвідування/вподобайки:

968 осіб вподобали сторінку, 1049 людей стежать за сторінкою.

II. Група в соціальній мережі Фейсбук «Вчимо історію онлайн».

Адреса групи: https://www.facebook.com/groups/1483874508453391.

Групу створена 31 березня 2020 р.; адміністратор групи Мороз П. В., старший науковий співробітник відділу суспільствознавчої освіти.

Учасники групи: науковці, методисти, вчителі/викладачі історії, права та громадянської освіти; автори навчальної літератури; спільноти видавництв та музеїв; інші, хто цікавиться історією та методикою її викладання.

Мета створення групи: створення мережевого освітнього простору для обговорення проблем історичної освіти та науки; обмін між учасниками групи інформацією (текстовими повідомленнями, фото та відеоматеріалами, покликаннями на навчальні та наукові онлайнові ресурси з історії), організація дискусій щодо питань історичної освіти; популяризація та обговорення історичної літератури, фахових статей; організація опитувань з актуальних питань методики навчання історії, правознавства, громадянської освіти; кількісний і якісний аналіз результатів анкетування; презентація освітніх заходів і подій.

Види викладених у групі матеріалів:

- інформаційні матеріали учасників групи (текстові повідомлення, фото та відеоматеріали, покликання на навчальні та наукові онлайнові ресурси з історії;

- науково-методичні розробки, посібники, підручники, статті учасників групи та покликання на них;

- покликання на опитування вчителів;

- інформація про освітні та наукові заходи, а також анонс подій та запрошення до участі в актуальних заходах.

Статистика відвідування/вподобайки/коментарі:

Усього учасників: 6252 (станом на 31 травня 2021 року).

За період з 23 лютого 2020 р. по 31 травня 2021 р. учасниками групи було розміщено 3167 дописів, зроблено 1431 коментарів, 55571 вподобань (реакцій).

Отже, в умовах пандемії, переходу на дистанційну та змішану форму навчання і роботи соціальні мережі дають змогу розширити інформаційно-комунікаційне середовище вчителя, методиста, науковця. Їх перевагами є загальнодоступність, інтерактивність, мультимедійність ко- 
мунікативного простору, зрозумілий інтерфейс, можливість участі у спільнотах представників різних освітніх і наукових спільнот; різноманітність форм комунікації (коментарі, опитування, голосування, підписки тощо).

Використання соціальної мережі Facebook $€$ ефективним засобом швидко та ефективно налагодити взаємодію з цільовою аудиторією та надавати методичну допомогу вчителям історії, основ правознавства та громадянської освіти. 3 іншого боку, результати опитувань, коментарі та дописи відвідувачів ресурсу допомагають співробітникам відділу отримувати цінну й необхідну інформацію, що може бути використана в ході проведення наукових досліджень, педагогічного експерименту, підготовки методичної та навчальної продукції.

Проведені протягом року співробітниками відділу суспільствознавчої освіти через мережеві ресурси системні опитування представників педагогічної спільноти виявили позитивні чинники дистанційного навчання. 3-поміж інших зазначимо підвищення ролі мотиваційного складника навчання учнів, зростання їхньої самостійності, особистої відповідальності за результати навчання, вдосконалення навичок користування освітніми сервісами, онлайн ресурсами тощо.

Водночас учителі виокремлюють найбільш вразливі сторони дистанційного навчання учнів як-от:

- віртуальне навчання зменшує соціальну взаємодію на всіх рівнях: учні-учні, учні-вчителі, учителі-батьки, що послабляє освітню співпрацю та партнерство учасників освітнього процесу, формування й розвиток комунікативних умінь і навичок учнів;

- специфіка дистанційного навчання призводить до нівелювання компетентнісного змісту навчання: зменшується когнітивний, ставленнєвий і навіть діяльнісний контент;

- дистанційне навчання відбувається ефективніше там, де адміністрація освітнього закладу координує освітній процес, максимально можливо забезпечує дієвість усіх його ланок.

11 грудня 2020 року Міністерство освіти та науки України спільно 3 Українським інститутом розвитку освіти, Міністерством цифрової трансформації України та громадською спілкою «Освіторія» створили сучасний онлайн-ресурс - платформу для дистанційного та змішаного навчання «Всеукраїнська школа онлайн» (далі - ВШО) (https://Ims.e-school.net. ua/). Метою ВШО визначено забезпечення рівного доступу учнів 5-11 класів і вчителів до якісного навчального контенту з 18 основних предметів (https://mon.gov.ua/ua/tag/vseukrayinska-shkola-onlajn). Зазначимо, що вказаний проєкт якісно відрізняється від Всеукраїнської школи онлайн періоду карантину весни 2020 року (у групі експертів із надан- 
ня фахової допомоги і методичних рекомендацій вчителям Школи була Малієнко Ю.Б.).

У рамках співпраці з Українським інститутом розвитку освіти та громадською спілкою «Освіторія» співробітники відділу суспільствознавчої освіти з листопада 2020 року по травень 2021 року були залучені до цього проєкту: Вікторія Кришмарел здійснювала експертизу сценаріїв та відео уроків курсу «Всесвітня історія. 7 клас» (усього 18 уроків); Тетяна Ремех надавала методичні консультації щодо сценаріїв, відео уроків, тестів із предмета «Основи правознавства, 9 клас» (усього 18 уроків).

Досвід участі у підготовці та експертизі навчальних матеріалів дає змогу визначити такі особливості ВШО:

- платформа $є$ безоплатною й підтримується провідними мобільними операторами, що уможливлює вільний доступ до неї учнів і вчителів різних регіонів, в тому числі й тих учнів, які проживають на тимчасово окупованих територіях України і бажають здобувати освіту за українською державною програмою;

- уроки на платформі відповідають державному стандарту та календарному плану з певного предмету/курсу;

- щотижневе оновлення контенту уможливило використання вчителями відео уроків відповідно до програми;

- відео уроки побудовані за принципом мікронавчання; кожний урок містить відео, конспект і тести для перевірки засвоєних знань;

- на платформі наявний такий функціонал як кабінет учителя, який дає змогу вчителю-предметнику навчати на платформі власні класи, відслідковувати прогрес своїх учнів, модифікувати курси спеціально для них та/або створювати власні курси.

Зрозуміло, що ВШО є придатною не лише для навчання учнів під час карантину чи локдауну. Вчителі можуть застосовувати платформу ВШО для змішаного навчання на уроках, а учні мають можливість користуватися платформою для ознайомлення з темою, яку слід надолужити або з якою варто краще розібратися. Тож формат ВШО дає змогу учням та вчителям (і навіть батькам, особливо за умов дистанційного навчання) використовувати представлені на платформі матеріали як безпосередньо на уроці, так і для самостійної роботи в будь-який час. Безумовною перевагою вважаємо й можливість повернутися до будь-якого етапу кількома кліками мишки, супровід відео субтитрами, розгортання ілюстрації на весь екран, покликання на додаткові ресурси з теми, тести для відслідковування учнем власного навчального поступу тощо. 
Утім, специфіка ВШО накладає суттєві обмеження на матеріали з дидактико-методичної точки зору: відсутній зворотній зв'язок з учнями, відео є суто розповідним (без запитань і пізнавальних завдань), з огляду на сприйняття інформації має тривалість біля 10 хв., що для переважної більшості тем (зокрема, з історії та основ правознавства) дає змогу лише окреслити ключові поняття, повідомити чільні події та явища, назвати основні джерела. Крім того, ані з історії, ані з основ правознавства (як, власне, і з інших предметів) так і не створені уроки з усіх тем, передбачених календарним планом. Стартував проєкт лише у листопаді 2020 року (відтак уроки за вересень-жовтень не були створені, відзняті й виставлені на платформу). Останні уроки в цьому навчальному році були відзняті у квітні 2021 року (теми за травень залишилися неохопленими). 3 огляду на зазначене вище ВШО розглядаємо в якості додаткового ресурсу як для дистанційного і змішаного, так і очного навчання учнів закладів загальної середньої освіти.

Проведені співробітниками відділу суспільствознавчої освіти дослідження дали змогу виявити основні проблеми і виклики, які висуває перед системою освіти України перехід до різних форм онлайн-навчання як-от такі: недостатня готовність вчителів до користування доступними онлайн-сервісами; непідготовленість учнів до самоорганізації та участі в онлайн-навчанні; відсутність/брак технічних можливостей організації ефективного онлайнового навчання у низки вчителів та учнів; відсутність підтримки педагогів з боку державних органів, органів місцевого самоврядування, ОТГ в реалізації онлайн-навчання; брак методичної літератури, рекомендацій і ресурсів для навчання історії як предмета, що обумовило досить слабкий рівень проведення занять (брак інтеракції, творчих завдань, залучення альтернативних джерел та ін.); значні додаткові витрати часу на підготовку до уроків для значної частини вчителів; недостатня мотивація вчителів до запровадження ефективного онлайн-навчання учнів [69].

Результати дослідження співробітниками відділу суспільствознавчої освіти питання запровадження дистанційного навчання, проведеного впродовж 2020-2021 рр., ґрунтовані на аналізі опитувань, анкетування, інтерв'ювань учителів, адміністрації освітніх закладів, дописів представників педагогічної спільноти на сторінці та групі відділу у Facebook, виступів на круглих столах із педагогами експериментальних закладів розміщено в електронній бібліотеці [2]. 


\section{3. ОСОБЛИВОСТІ ДИСТАНЦІЙНОГО НАВЧАННЯ ПРИРОДНИЧИХ ПРЕДМЕТІВ}

Упродовж упровадження у країні карантинних обмежень відділом біологічної, хімічної та фізичної освіти Інституту педагогіки НАПН України проводився моніторинг стану навчання біології, хімії і фізики у закладах загальної середньої освіти, метою якого було з'ясувати умови, результати і проблеми дистанційного навчання. Завдання дослідження стосувалися:

- способів комунікації, видів навчального матеріалу, сервісів, освітніх платформ, які вчитель використовує для організації навчання під час карантину,

- підходів до організації навчальної діяльності учнів, формату перевірки та оцінювання роботи учнів,

- оцінювання ефективності засобів і технологій навчання;

- пропозицій щодо навчально-методичного забезпечення (розроблення нового та адаптації існуючого до умов дистанційного навчання).

Було зроблено такі висновки:

1. Більшість учителів проводять уроки в сервісі Zoom, а деякі ведуть прямі ефіри на своїх каналах YouTube і використовують власні блоги.

2. Для створення завдань учителі використовують різноманітні ресурси, а саме: освітній портал «На урок», Google-форми (тести), сайт «Всеосвіта» та тощо.

3. Командна робота, взаємодія між усіма учасниками освітнього процесу - адміністрацією школи, вчителями, учнями і батьками - набуває особливої важливості.

Порівняно успішним дистанційне навчання виявилося в тих школах, де адміністрацією було проведено підготовчу роботу з моменту запровадження карантину, узгоджено правила та розклад взаємодій усіх учасників освітнього процесу, обрано єдину платформу для дистанційного навчання.

4. Багато вчителів біології, хімії, фізики не готові до дистанційного навчання, оскільки не володіють сучасними ІКТ. Упродовж карантину вчителям довелося опановувати технологію дистанційного навчання самостійно або з допомогою колег.

5. Проблеми зумовлені неможливістю підтримувати якісну комунікацію вчителя й учнів через нестабільний інтернет-зв'язок, нестачу технічних засобів (ноутбук, програмне забезпечення, веб-камери 
тощо). Учні недостатньо мотивовані до дистанційного навчання, подекуди не виходили на зв'язок.

6. Використання традиційної урочної форми не сприяє досягненню результатів в умовах тривалого дистанційного навчання; невисокий рівень сформованості в учнів умінь самоорганізації і самостійної роботи; брак методичних навичок роботи в дистанційному форматі призводить до нераціонального витрачання часу, перевантаження учнів.

7. Має місце значне перевантаження вчителів, оскільки доводиться працювати на кількох освітніх платформах, складати завдання на різних сервісах, виставляти оцінки зовсім на інших, перевіряти завдання, які учні надсилають на електронну пошту або певний месенджер (зокрема смартфон), тобто переглядати сотні неякісних фото, що негативно впливає на зір.

Слід зазначити, що система освіти не була готова до такого виклику (застаріле положення про дистанційне навчання, брак інформації про методику організації дистанційного уроку та інструменти для організації дистанційного навчання, електронні ресурси, платформи тощо).

Нині можна стверджувати, що з переходом на дистанційне навчання значно зріс рівень цифрової компетентності вчителів, ними накопичено цінний досвід проведення уроків у дистанційній або змішаній формах навчання, який, поза сумнівом, стане в пригоді у наступній роботі.

Досвід учителів і рекомендації науковців відділу систематично висвітлюються на сторінках науково-методичних часописів «Біологія і хімія в рідній школі» й «Фізика та астрономія в рідній школі» та інших періодичних видань, у збірниках наукових праць, матеріалах конференцій.

\subsection{1. Особливості дистанційного навчання біології і хімії}

Інструменти організації дистанційного навчання. 3 моменту запровадження карантинних обмежень навчання відбувається частково в дистанційній або змішаній формах навчання, коли практикують поєднання різних режимів роботи (онлайн та аудиторну) у різних класах чи в різний час. Для оптимізації роботи під час дистанційного навчання вчителю важливо правильно побудувати свою діяльність спільно з адміністрацією та усім педагогічним колективом. Це перехід до роботи на одній електронній платформі й зменшення навантаження для перевірки робіт шляхом під'єднання автоматичних функцій або використання тестових оцінювальних автоматичних форм.

Окрім того, сьогодення диктує нам нові правила роботи у зв'язку з низкою причин. По-перше, це використання сучасних інструментів для 
організації різноманітних форм навчання. По-друге, слід врахувати й нові нормативні документи, які регламентують сферу освіти (Закон України «Про освіту», Закон України «Про загальну середню освіту», Положення про дистанційне навчання, Санітарний регламент для закладів загальної середньої освіти, Професійний стандарт «Вчителя закладу загальної середньої освіти»).

Для організації дистанційного навчання існує два режими роботи: асинхронний та синхронний. Для кожного з цих режимів притаманні свої особливості та «інструменти». Розглянемо особливості цих режимів докладніше.

Синхронний режим передбачає взаємодію між суб'єктами дистанційного навчання, під час якої учасники одночасно перебувають в електронному освітньому середовищі або спілкуються за допомогою засобів аудіо-, відеоконференції. Інакше кажучи, це проведення уроку в режимі реального часу в обраному цифровому середовищі. Рівночасно присутні вчитель та учні класу спілкуються приблизно так, як це відбувається на звичайному уроці.

Асинхронний режим означає взаємодію між суб'єктами дистанційного навчання, за якої учасники взаємодіють між собою із затримкою в часі, застосовуючи при цьому інтерактивні освітні платформи, електронну пошту, форуми, соціальні мережі тощо. Можна сказати, що це режим більш самостійного навчання, яке водночас підтримується вчителем з використанням відповідних цифрових інструментів.

Які переваги та недоліки цих форматів навчання? Синхронне навчання - це швидкий і безпосередній зворотний зв'язок між учителем і учнями. Відповіді та реакції надаються в режимі реального часу, майже так само, як і на звичайному уроці. Звісно, $є$ технологічні обмеження, які означають, що одночасно говоритиме лише хтось один, і на екрані воднораз можна побачити не всіх учасників, якщо їх достатньо багато. Лише в синхронному форматі можна організувати безпосередню взаємодію учнів у малих групах, швидко обговорити питання та прийняти рішення.

Однак синхронне навчання вимагає онлайн-присутності всіх учасників у чітко визначений час. Це може бути проблемою, особливо коли вдома $€$ кілька осіб з графіками, що накладаються. Певна частина синхронного заняття йде на узгодження технічних перешкод, перепитування й уточнення через непередбачувані перебої зі зв'язком та інші організаційні моменти.

Натомість асинхронний режим передбачає роботу за власним графіком та у власному темпі й максимально використовує переваги змішаного навчання. Це дозволяє опановувати матеріал, орієнтуючись на 
власне розуміння, а не на темп решти групи. Водночас асинхронний режим може давати відчуття більшої ізольованості, адже знижується відчуття навчальної спільноти, якщо спеціально не підтримувати його. Крім того, це вимагає від учнів доволі високої самодисципліни та розвиненого вміння керувати своїм часом, що може бути досить складним, зокрема за відсутності попереднього досвіду такої роботи.

Таким чином, розглянувши особливості синхронного й асинхронного форматів навчання, можна виокремити різні види та форми діяльності, які дадуть змогу максимально ефективно застосувати кожен із цих режимів.

Синхронне заняття варто використовувати для організації освітнього процесу, відповідей на запитання щодо змісту чи розв'язання проблем доступу до цифрових сервісів, які виникли в учнів, можливо, пропонуючи альтернативні варіанти виконання завдань.

Водночас добре працює схема відведення певних періодів навчального дня для консультацій - учні знають, що можуть звернутись у цей час і отримати безпосередню відповідь. Якщо ж запитання виникає в інший момент, варто встановити правила надання відповіді поза межами таких консультацій. Наприклад, на запитання, надіслане вчителеві електронною поштою чи в месенджер між 9-ю та 15-ю годиною, можна очікувати відповідь упродовж однієї години.

При асинхронній організації освітнього процесу особливої важливості набуває систематичність наповнення цифрової навчальної платформи, обраної закладом освіти. Потрібно надавати чіткі інструкції та передбачити різні канали комунікації (електронна пошта, доступна форма зворотного зв'язку, месенджер, телефон тощо) на випадок виникнення технічних негараздів.

Щодо вивчення нового матеріалу. За традиційного підходу на уроці вчитель повідомляє новий зміст, а вдома (асинхронно) учні його опрацьовують, виконуючи вправи та завдання. Такий підхід є виправданим в окремих випадках, коли учні не мають попереднього досвіду самостійного опрацювання матеріалу, або цей матеріал є зовсім новим чи високої складності. Частіше ж доцільніше спробувати реалізовувати підхід «перевернутого класу», коли новий матеріал опрацьовують асинхронно, а на онлайновому занятті відбувається його обговорення та практичне закріплення.

Таким чином учні можуть отримати матеріал у зручному для себе форматі. Це може бути опрацювання матеріалів до уроку, відеоуроку від свого вчителя, навчальне відео з YouTube, TedX чи інших освітніх каналів, платформи Всеукраїнської школи онлайн тощо. Плануючи вико- 
ристання таких джерел, учитель має врахувати, що час опрацювання цих матеріалів не може перевищувати тривалості асинхронних занять.

Якщо заклад освіти має обґрунтовані сумніви щодо можливості всіх учнів приєднатися до синхронних онлайнових занять, треба забезпечити отримання навчальних матеріалів та пояснень альтернативними шляхами. Це можуть бути відеозаписи, відкриті для перегляду в будьякий час, покликання на сторінки доступного навчального блогу учителя чи посібника, надання доступу до презентації, конспекту заняття чи інших матеріалів.

Варто зазначити, що більшість сервісів проведення онлайнових уроків дозволяють здійснювати запис занять. В окремих випадках доступ до таких записів можна використати як альтернативу відвідуванню синхронних уроків за умови забезпечення оптимальної тривалості та наповнення запису. У цифровому навчанні практикують короткі відеоролики тривалістю до 8-10 хвилин. Тож у разі планованого подальшого використання запису заняття варто обмежувати його тривалість або структурувати його так, щоб можна було виокремити найбільш інформативний фрагмент.

Санітарний регламент для закладів загальної середньої освіти, який діє з 1 січня 2021 року, передбачає вимоги до організації роботи з технічними засобами навчання, зокрема комп'ютерами, планшетами, іншими гаджетами.

Так, обмежено час безперервної роботи з технічними засобами навчання:

- для учнів 1 класу - не більше 10 хвилин;

- для учнів 2-4 класів - не більше 15 хвилин;

- для учнів 5-7 класів - не більше 20 хвилин;

- для учнів 8-9 класів - 20-25 хвилин;

- для учнів 10-11 (12) класів на 1-й годині занять - до 30 хвилин, на 2-й годині занять - 20 хвилин;

- при здвоєних навчальних заняттях для учнів 10-11 (12) класів не більше 25-30 хвилин на першому навчальному занятті та не більше 15-20 хвилин на другому навчальному занятті.

Отже, тривалість навчальних занять, визначена Законом «Про повну загальну середню освіту», зберігається: 35 хвилин для 1 класу, 40 хвилин для 2-4 класів, 45 хвилин для 5-12 класів. Обмежується лише час безперервної роботи з комп'ютером для уникнення ризиків для здоров'я.

Варто пам'ятати, що фронтальна робота не може займати більшість часу заняття, незалежно від обраного формату взаємодії. Доцільно від- 
водити значну частину уроку на індивідуальну та групову роботу учнів, виконання практичних вправ і застосування активних методів навчання.

На синхронних заняттях варто використовувати інтерактивні прийоми, практикувати роботу в малих групах (активуючи кімнати breakout rooms відповідних сервісів відеоконференцій). Доречно буде скористатись інструментами миттєвої взаємодії, наприклад Kahoot, MentiMeter, Classtime та аналогічними. Іншими словами, треба максимально зважати на факт одночасної присутності великої кількості учасників для підтримки спільної роботи та взаємодій.

Найчастіше вчителі намагаються реалізувати «гібридний» варіант, який поєднує онлайнове спілкування з асинхронними завданнями, таким чином, сама собою реалізується модель «подвійного перевернутого класу», в якій не тільки робота з теорією, але й практичне опрацювання змісту здійснюється засобами комунікаційних технологій.

Розглянемо докладніше деякі найпростіші й популярні інструменти для організації дистанційного навчання.

Відеосервіси - це сайти, програми або застосунки, що дозволяють безкоштовно (переважно) зберігати, переглядати, коментувати, редагувати, створювати відеофрагменти, проводити онлайн конференції, зустрічі, заняття, уроки тощо. До таких сервісів належать: Zoom, YouTube, Cisco WebEx, Google Hangouts, Google Meet, Microsoft Teams, Skype, FreeConferenceCall.com, Ding Talk.

Zoom - сервіс для проведення онлайн-конференцій, нарад, зустрічей; сервіс має безкоштовну версію. 40 хв, до 100 учасників.

Недоліки Zoom: програма недостатньо захищена від дій хакерів та безпосередніх учасників конференцій.

YouTube - популярний відеохостинг, що надає послуги розміщення відеоматеріалів. Станом на серпень 2019 року YouTube є другим за відвідуваністю сайтом в Інтернеті. Є можливість прямих ефірів та інтеграції з іншими відеосервісами, налаштування власного каналу.

Cisco WebEx - це хмарний відеосервіс для проведення будь-яких web-конференцій, що дозволяє учасникам обмінюватися інформацією в будь-який момент часу з глобального хмарного середовища, в будь-якому місці, використовуючи комп'ютер або мобільні пристрої.

Переваги:

- Безпека - використання хмарних технологій для проведення нарад дозволяє забезпечити високий рівень безпеки при спільній роботі;

- Якісне обслуговування і доступ до оновлень.

- Гнучкість - не обов'язково встановлювати. 
- Тривалість (безкоштовної версії) - до 50 хв, до 100 осіб.

- Мобільність - можливість роботи з будь-якого пристрою.

Недолік:

- Високі вимоги до комп'ютерів учасників відеоконференції.

Google Hangouts - це програмне забезпечення для миттєвого обміну повідомленнями та відеоконференцій. Простий у користуванні. Підтримка проведення конференцій до 100 осіб.

Недоліки:

- Доступний лише з G-Suite.

- Програма працює лише в браузері або як розширення Chrome.

- Обмежена функціональність.

- Відсутність статусів доступності. Додаток показує лише статус онлайн чи офлайн.

(Гугл анонсував закриття у 2020 році й перехід до корпоративної версіï).

Google Meet - корпоративний засіб для відеоконференцій на базі надійної та захищеної глобальної інфраструктури Google.

- Meet включено в пакети Google Workspace i G Suite for Education.

- Для корпоративної роботи потрібен домен (14 днів безкоштовний тариф).

- Зараз можна організувати або приєднатися до конференції із пошти Gmail (відкритий доступ під час пандемії COVID-19).

Microsoft Teams - це сучасна корпоративна платформа, спеціально розроблена для використання у глобальній хмарі Office 365.

- Microsoft Teams $€$ конкурентом таких сервісів, як Slack, i $є$ еволюційним оновленнями від Microsoft Skype для бізнесу.

- Платформа об'єднує все в спільному робочому середовищі, яке містить чат для нарад, файлообмінник та корпоративні програми.

Недолік:

- дуже високі вимоги до комп'ютерів учасників.

Skype (Скайп) - це безкоштовне програмне забезпечення, що забезпечує шифрований голосовий зв'язок через Інтернет між комп'ютерами (VoIP), а також платні послуги для дзвінків на мобільні і стаціонарні телефони. Дозволяє:

- вести індивідуальне листування, обмінюватися повідомленнями в режимі реального часу;

- проводити відеоконференції та наради за участю до 50 учасників;

- пересилати файли, вести записник, одержувати новини, здійснювати пошук інформації, не виходячи з програми, за допомогою 
панелі інструментів Google (панель інструментів налаштовується під час інсталювання програми).

FreeConferenceCall.com - це безкоштовний інструмент для проведення конференцій і спільної роботи, який створює простір без кордонів, де кожен може підключатися, поділитися презентацією, завантажити документ тощо. Кожний обліковий запис містить безкоштовні онлайн зустрічі. Тривалістю до 6 год, кількістю до 1000 осіб.

Ding Talk - сервіс для відеозв'язку та дистанційного навчання. Він повністю безкоштовний. Для користування потрібно завантажити програму на смартфон, планшет чи ПК. Мова користування - англійська. Інтерфейс простий, інтуїтивно зрозумілий.

- Реєстрація відбувається за номером телефону. Після завантаження програми потрібно її відкрити, вибирати необхідний код країни (для України це +380), написати номер свого мобільного та натиснути кнопку «Send».

- СМС із кодом - пишемо його у відповідній графі (під номером). Після цього натисніть кнопку «Register», встановіть свій пароль і починайте працювати.

Віртуальні інтерактивні дошки - це мережевий соціальний ресурс, призначений для організації спільної роботи зі створення й редагування зображень і документів, спілкування в реальному часі.

Можуть використовуватися:

- як майданчик для групової роботи, проведення «мозкового штурму», узагальнення та систематизації знань, рефлексії;

- для розміщення навчальної інформації, практичних завдань;

- для організації спільного онлайн виконання домашнього завдання;

- для розміщення ідей проєктів та їхнього онлайн обговорення;

- як інструмент організації спільної діяльності учнів.

Найбільш популярні інтерактивні дошки, що зараз використовуються - це Padlet, Lino it, WikiWall, Scribblar, Popplet, Twiddla.

Скринкасти (від англ. screen - екран, англ. broadcasting - передача, мовлення) - це цифровий відеозапис інформації, виведеної на екран комп'ютера, також відомий як video screencapture (дослівно «відеозахоплення екрана»). Часто супроводжується голосовими коментарями. Скринкаст набагато практичніший, ніж текстовий опис, інструкція чи посібник, адже учні відразу бачать, які потрібно виконувати дії, про які йдеться у відеодемонстрації. Розглянемо деякі з них.

CamStudio - безкоштовна програма для запису всього, що відбува€ться на екрані монітора (в файл AVI або SWF). Створену презентацію в 
Microsoft Office PowerPoint можна зберегти у відеоформаті. Для цього перед початком показу слайдів запускаємо, налаштовуємо CamStudio, починаємо демонстрацію презентації.

OBS Studio - безкоштовна, але дуже потужна за можливостями програма для запису з відкритим вихідним кодом, призначена для створення прямих ефірів та запису відеороликів.

UVScreenCamera - програма для захоплення екрану, запису дій користувача, створення навчальних відеороликів, презентацій тощо.

FlashBack Express - це програма, призначена для запису зображення екрану монітора.

WebcamXP - це програма відеореєстратор, яка дає змогу провести захоплення зображення з декількох джерел.

Ezvid - це безкоштовний інструмент для захоплення екрану з базовими можливостями обробки відео.

Screencast-o-matic - програма-скриншотер, за допомогою якої можна захоплювати будь-яку ділянку екрана з можливостю додавання розповіді та відео з вебкамери.

Bandicam - зручна програма для запису екрану OC Windows, яка може записувати будь-що на екрані комп'ютера у високоякісне відео.

OpenShot - безкоштовний редактор, за допомогою якого можна відредагувати будь-яке відео, обрізати та накласти необхідні спецефекти.

Отже, онлайновий складник дистанційного навчання можна організувати в різних комбінаціях синхронного й асинхронного режимів взаємодій, підсилюючи їхні переваги.

«Всеукраїнська школа онлайн». Якщо на початку роботи в умовах пандемії вчителям доводилося розв'язувати проблеми самотужки, то пізніше МОН України було прийнято низку рішень, спрямованих на організацію більш ефективного дистанційного навчання. Саме таким рішенням стала «Всеукраїнська школа онлайн», яку в форматі телевізійних уроків було запущено 2 квітня 2020 року, і її нова версія «ВШО 2.0», яка була представлена у грудні 2020 року, і робота над якою триває нині. У викладанні в школі активну участь беруть наукові співробітники Інституту педагогіки, їхній досвід дає змогу проаналізувати процес навчання і зробити деякі висновки.

Нижче наводиться порівняння двох спроб організації централізованої дистанційної освіти: телевізійні/відеоуроки «Всеукраїнської школи онлайн» у квітні-червні 2020 р. та уроки «ВШО 2.0» у грудні 2020 року (таблиця 4.2.). 
Таблиця 4.2

Організація централізованої дистанційної освіти

\begin{tabular}{|c|c|c|}
\hline & $\begin{array}{c}\text { «Всеукраїнська } \\
\text { школа онлайн», кві- } \\
\text { тень-червень } 2020 \text { р. }\end{array}$ & $\begin{array}{c}\text { «ВШО 2.0», грудень } \\
2020 \text { р. }\end{array}$ \\
\hline Формат & $\begin{array}{l}\text { Відеоуроки, що } \\
\text { демонструються по } \\
\text { телебаченню та на } \\
\text { Ютьюб-каналі МОН } \\
\end{array}$ & $\begin{array}{l}\text { Відеоуроки, конспек- } \\
\text { ти та тести на он- } \\
\text { лайн-порталі https:// } \\
\text { Ims.e-school.net.ua/ }\end{array}$ \\
\hline $\begin{array}{l}\text { Формат представлення } \\
\text { матеріалів }\end{array}$ & $\begin{array}{l}\text { Відеолекція + пре- } \\
\text { зентація (паралельно } \\
\text { або на весь екран), за } \\
\text { потреби - маркерна } \\
\text { дошка, зйомки до- } \\
\text { слідів } \\
\end{array}$ & $\begin{array}{l}\text { Відеолекція або пре- } \\
\text { зентація (демонстра- } \\
\text { ція слайдів замість } \\
\text { лектора), розв'язання } \\
\text { задач на планшеті (не } \\
\text { реалізоване) }\end{array}$ \\
\hline $\begin{array}{l}\text { Середня тривалість } \\
\text { відео }\end{array}$ & $30-35$ хв. & $10-15$ хв. \\
\hline $\begin{array}{l}\text { Спосіб начитування } \\
\text { лекції }\end{array}$ & По пам'яті & 3 відеосуфлера \\
\hline \multicolumn{3}{|l|}{$\begin{array}{l}\text { Наявність редагування } \\
\text { сценаріїв: }\end{array}$} \\
\hline Вчитель-експерт & + & + \\
\hline $\begin{array}{l}\text { Запрошений експерт } \\
\text { УІРО }\end{array}$ & - & + \\
\hline Мовний редактор & - & + \\
\hline $\begin{array}{l}\text { Антидискримінаційна } \\
\text { експертиза }\end{array}$ & - & + \\
\hline $\begin{array}{l}\text { Постперегляд знятих } \\
\text { відеоматеріалів }\end{array}$ & - & + \\
\hline
\end{tabular}

Отже, варіант «ВШО 1.0» був орієнтований саме на представлення інформації в умовах реальної школи; у варіанті «ВШО 2.0» суто шкільного в лекціях було менше: основною формою представлення матеріалів була демонстрація слайдів.

Відеоуроки «ВШО 1.0» з демонстрацією по телебаченню давали можливість узгодити матеріал різних підручників, що їх використовували в різних школах. На платформі «ВШО 2.0» окрім відеолекцій, покликаних показати складні питання, унаочнити їх на якомога простіших моделях, та конспектів, було запропоновано формат онлайн-тестів. Серед них найбільш рекомендованими були завдання з обиранням однієї правильної відповіді, хоча система підтримувала ще декілька типів 
завдань: множинний вибір, сортування, обирання зі списків, що випадають. Суттєвою перевагою «ВШО 2.0» була наявність багатокрокової експертизи сценаріїв (див. табл. 4.2).

Спільним для обох проєктів ВШО є орієнтація саме на відеозаписи уроків, яким приділялося найбільше уваги та ресурсів: студійна апаратура та велика кількість працівників, грим лекторів, тренінги з акторської майстерності для авторів тощо. Головний недолік обох проєктів «ВШО» - саме відеоформат, хоча й це найдешевший і найзрозумілішій для багатьох учасників процесу формат. Але значно кориснішою була б орієнтація на інтерактивні моделі, дослідження яких $\epsilon$, наприклад, одним із складників електронного формату міжнародного порівняльного дослідження PISA (а саме електронний формат буде реалізовано у наступному раунді, який має відбутися у 2022 р.). Створення сценаріїв таких моделей та їхня реалізація завдяки можливостям HTML5 дозволила б зберегти головний плюс проєкту BШО (доступність усюди, де $\epsilon$ інтернет), але замінила 6 спрямування з репродуктивного на компетентністне. Крім того, платформа «ВШО 2.0», так само, як і формат "ВШО 1.0», не передбачають ніяких механізмів і засобів організації взаємодії учнів, у той час як розв'язання проблем у співпраці $\epsilon$ також одним із видів природничо-наукової грамотності, який перевіряється у міжнародному порівняльному дослідженні PISA і брак якого гостро відчувається в наявному форматі дистанційного навчання.

Педагогічні програмні засоби, придатні для дистанційного навчання. Навчальне й методичне забезпечення дистанційного навчання розроблялось в Інституті педагогіки в минулі роки, задовго до упровадження карантинних обмежень Це посібники із власне дистанційного навчання, а також електронні підручники, навчальні посібники, віртуальні лабораторії, що можуть бути адаптовані до сучасних умов навчання, зокрема, біології і хімії:

1. Дистанційний курс "Шкільний курс з хімії, 8-11 кл.» Для 8-11 класу загальноосвітнього навчального закладу. - К.: Український центр дистанційної освіти Національного технічного університету «Київський політехнічний інститут» (УДЦО), 2005. URL: http://shkola.ostriv. in.ua/publication/code-3990E8826CCC5/list-211469C1327.

2. Педагогічний програмний засіб „Віртуальна хімічна лабораторія, 8-11 кл.» Для 8-11 класу загальноосвітнього навчального закладу. - К.: Інститут педагогіки АПН України, 2005. Квазар-Мікро, 2005. - ел. опт. диск (CD-ROM). 
3. Навчальне програмне забезпечення для викладання та вивчення хімії у 8 кл. загальноосвітніх навчальних закладів (ППЗ). - К,: Квазар-мікро, 2005. - ел. опт. диск (CD-ROM)

4. Програмно-методичний комплекс навчального призначення «Хімія, 9 клас» для загальноосвітніх закладів.- Рівне.: ПП «Контур плюс», 2006. - ел. опт. диск (CD-ROM)

5. Педагогічний програмний засіб для загальноосвітніх навчальних закладів «Бібліотека електронних наочностей «Хімія», 10-11 кл». К.: Квазар-Мікро, 2006. - - ел. опт. диск (CD-ROM)

6. Програмно-методичний комплекс навчального призначення «Органічна хімія, 10-11 клас» для загальноосвітніх навчальних закладів. - К.: ЗАТ «Транспортні системи», 2007. - ел. опт. диск (CD-ROM)

7. Віртуальна лабораторія. Біологія людини. 8-9 клас. Конструктор уроків : Для загальноосвітніх навчальних закладів. - К. : ЗАТ «Транспортні системи", 2006. - ел. опт. диск (CD-ROM)

8. Віртуальна лабораторія. Біологія людини. 8-9 клас.- електр. опт. диск.(CD-ROM) Додаток. Методичні рекомендації [Tекст].- К.: Інститут інформаційних педагогічних технологій, 2008.

\subsection{2. Особливості дистанційного навчання фізики та астрономії}

В умовах карантину особливої актуальності набуло використання технологій мобільного навчання. Одним із перспективних напрямів застосування смартфонів та планшетів в освітньому процесі з предметів природничого циклу $є$ візуалізація навчальної інформації через використання додатків доповненої реальності.

Опитування учнів експериментальних навчальних закладів, проведене за допомогою Classroom, установило, що 65 \% учнів має змогу працювати лише зі смартфона й лише $35 \%$ з персонального комп'ютера. Це потребує коригування методик проведення занять за дистанційною формою. Під час дистанційного навчання активно використовувався принцип BYOD - принцип активного використання особистих смартфонів, ноутбуків, планшетів та інших цифрових пристроїв школярів.

Включення в освітній процес смартфонів забезпечує формування в здобувачів освіти ціннісного ставлення до смартфона як засобу для дослідження навколишнього середовища. Проте дослідження, проведені за допомогою смартфонів, хоч і містять кількісні результати вимірювання фізичних величин, можуть аналізуватися лише задля отримання якісних висновків, оскільки через відсутність метрологічної повірки датчиків кількісні результати вимірювань різними смартфо- 
нами можуть різнитися й містять інструментальну похибку вимірювання, яку важко врахувати.

На уроках фізики для візуалізації різних елементів електричного кола використовується додаток «Elecrtricity AR», створений в Харківському національному університеті ім. В. Н. Каразіна. Освітня агенція міста Києва розробила додаток Book'VAR, що демонструє експерименти за допомогою технології доповненої реальності.

На допомогу школам, що прагнуть активно використовувати в освітньому процесі інструменти цифрової дидактики, за наукового супроводу відділу STEM-освіти Інститут модернізації змісту освіти було створено Віртуальний STEM-центр Малої академії наук України - STEM-лабораторія МАНЛаб [9]. Ресурс містить велику кількість методик для проведення занять із предметів природничого циклу з використанням цифрових лабораторій, готові моделі для друку фізичних приладів на 3D принтері. Для закладів загальної середньої освіти, що ще не мають сучасного обладнання для проведення досліджень, зроблено відеозаписи та викладено файли для завантаження результатів досліджень, що фіксуються за допомогою датчиків. Портал постійно збагачується новими здобутками вчителів та науковців, що можуть бути використанні в освітньому процесі.

Сучасні смартфони містять велику кількість датчиків й можуть стати своєрідною «мобільною цифровою лабораторією». За допомогою особистого смартфона здобувачі освіти можуть вимірювати різні параметри навколишнього середовища й проводити аналіз і статистичне оброблення отриманих результатів за допомогою спеціальних додатків [88].

Одним із сучасних додатків, що може бути використаним для проведення фізичних експериментів з використанням смартфонів, $\epsilon$ phyphox, що $є$ вільно поширюваним програмним забезпеченням, розробленим у 2-му інституті фізики Рейнско-Вестфальського Технічного університету Аахена. Безпосередньо в меню додатку наявна інструкція для виконання лабораторних досліджень та відеозапис експерименту, розміщений на хостингу YouTube. Додаток не містить локалізації українською мовою, але переклад інструкцій до виконання лабораторних робіт з цим додатком є на сайті Віртуального STEM-центру Малої академії наук України.

Педагогічні програмні засоби з фізики, що можуть бути використані в освітньому процесі на безоплатній основі:

1. Педагогічний програмний засіб „Віртуальна фізична лабораторія, 7-9 кл.» Для 7-9 класу загальноосвітнього навчального закладу. Київ: Інститут педагогіки АПН України, 2005. Квазар-Мікро, 2005. ел. опт. диск (CD-ROM). 
2. Педагогічний програмний засіб „Віртуальна фізична лабораторія, 10-11 кл.» Для 10-11 класу загальноосвітнього навчального закладу. - Київ: Інститут педагогіки АПН України, 2005. Квазар-Мікро, 2005. ел. опт. диск (CD-ROM). URL: https://bit.ly/3gQj9Dc.

3. Педагогічний програмний засіб „Бібліотека електронних наочностей, 7-9 кл.» Для 7-9 класу загальноосвітнього навчального закладу. Київ: Інститут педагогіки АПН України, 2005. Квазар-Мікро, 2005. ел. опт. диск (CD-ROM).

4. Педагогічний програмний засіб „Бібліотека електронних наочностей, 10-11 кл.» Для 10-11 класу загальноосвітнього навчального закладу. Київ: Інститут педагогіки АПН України, 2005. Квазар-Мікро, 2005. ел. опт. диск (CD-ROM).

5. Педагогічний програмний засіб „Фізика, 7 кл.» Для 7 класу загальноосвітнього навчального закладу. Київ: Інститут педагогіки АПН України, 2004. Квазар-Мікро, 2004. ел. опт. диск (CD-ROM).

6. Педагогічний програмний засіб „Фізика, 8 кл.» Для 8 класу загальноосвітнього навчального закладу. Київ: Інститут педагогіки АПН України, 2004. Квазар-Мікро, 2004. ел. опт. диск (CD-ROM).

7. Педагогічний програмний засіб „Фізика, 8 кл.» Для 8 класу загальноосвітнього навчального закладу. Київ: Інститут педагогіки АПН України, 2005. Квазар-Мікро, 2004. ел. опт. диск (CD-ROM).

Дистанційне навчання астрономії з використанням електронних освітніх ресурсів. Інтернет відкрив не лише широкі можливості для застосування астрономічної інформації в освіті [33], але й дав змогу на новому рівні організовувати й здійснювати дистанційне навчання астрономії [31], зокрема й з використанням телескопів з віддаленим доступом [32]. Нині Всесвітня мережа містить велику кількість різноманітних ресурсів, призначених тим, хто навчає чи навчається астрономії. $€$ такі ресурси і в її українському сегменті.

3 осені 2008 р. в функціонує сайт «Астроосвіта», призначений для науково-ментодичної підтримки навчання астрономії в закладах загальної середньої освіти (автор і модератор Іван Крячко).

Основні розділи сайту: Астроновини | Методика | Інфотека | Планетарій | Наше небо | Підручник | Проекти | Форум (рис. 3). 


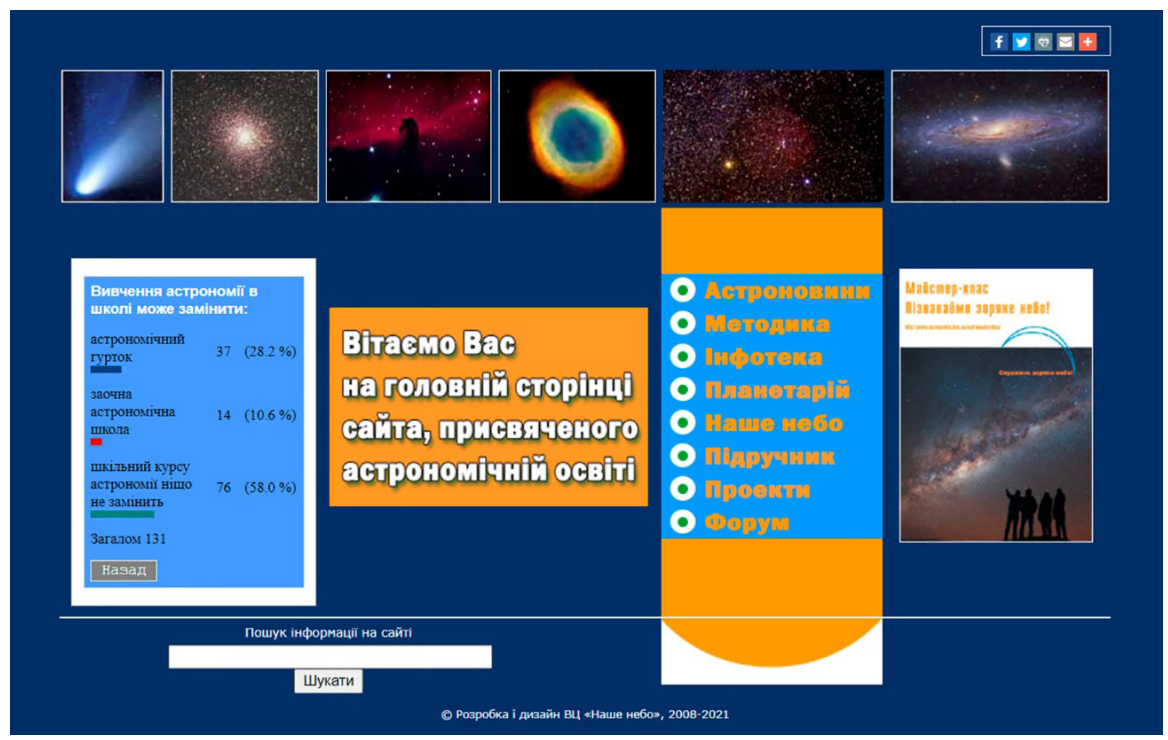

Рис. 3. Головна сторінка сайту «Астроосвіта»

Розділ «Астроновини» вміщує регулярні повідомлення про нові відкриття в астрономії. Ця інформація дає змогу користувачам сайту стежити за результатами наукових досліджень як вітчизняних, так і зарубіжних науковців та наукових установ. Повідомлення із цього розділу сайту може використати вчитель, щоб підтримувати інтерес учнів до вивчення астрономії, а також з метою розширення своїх уявлень про досягнення сучасної астрономії. Натомість учні, завдяки цим повідомленням, мають змогу як розширювати свій кругозір, так і отримувати додаткову астрономічну інформацію.

Розділ «Методика» (рис. 4) розраховано головно на вчителів і викладачів астрономії. Також у ньому знайде корисну для себе інформацію також учень, який вдається до самоосвіти. Розділ вміщує матеріали щодо різних аспектів методики навчання астрономії. Тут подано інформацію про методичні посібники, зокрема, «Методику навчання астрономії у старшій загальноосвітній школі» (http://www.astroosvita.kiev.ua/metod/ metodyka-navchannia-astronomii.php), а також інші його роботи методичного змісту. До таких належить презентація «Навіщо Вам астрономія?». В ній йдеться про те, що астрономія дає окремій, тобто будь-якій конкретній, людині - не просто біологічній істоті, що обмежує своє життя лише пошуками їжі та піклується щодо потомства, а особистості, яка живе, мислить і пізнає себе й довкілля аж до обширу нашого Всесвіту. 


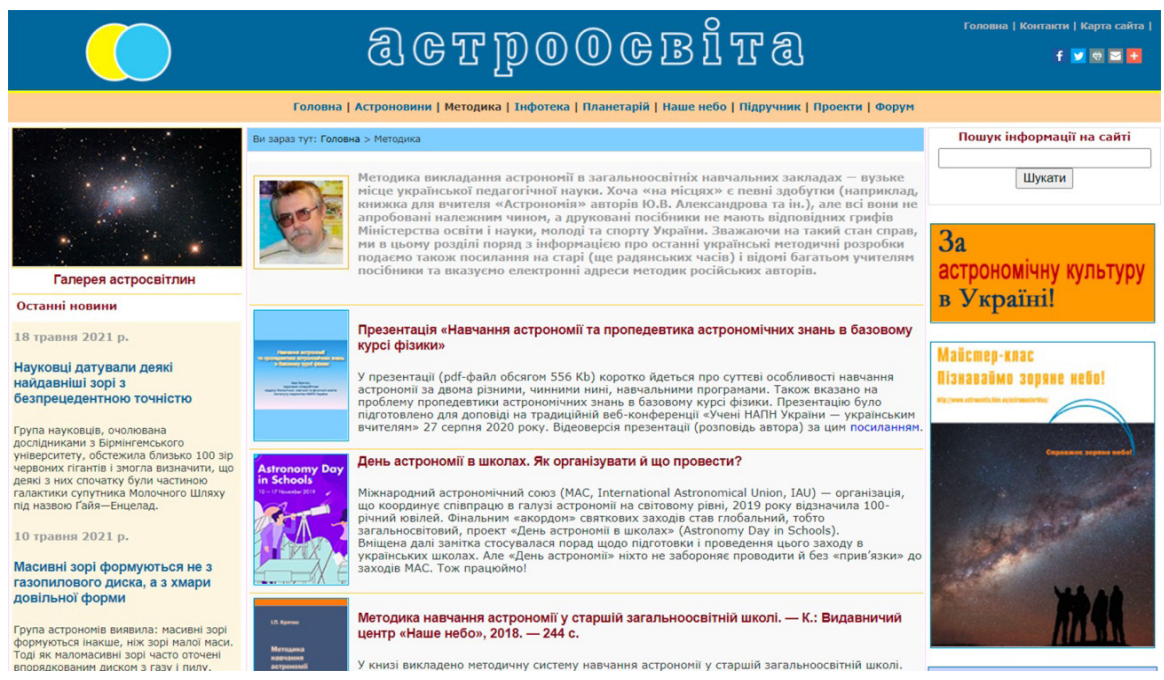

\section{Рис. 4. Перша сторінка розділу «Методика» сайту «Астроосвіта»}

Презентацію «Навіщо і як навчати астрономії у старшій школі?» (http:// www.astroosvita.kiev.ua/metod/Navishcho-i-yak-navchaty-astronomii.pdf) призначено для вчителів, які викладають астрономію в загальноосвітніх навчальних закладах. У ній зосереджено увагу на засадничих питаннях методики: навіщо навчати, чого та як навчати? Вона частково «перегукується» зі змістом презентації «Нове в астрономії для вчителя і учня» (http://www.astroosvita.kiev.ua/metod/Astronomiia_NAPN_2016-2017. pdf), а також суттєво ії доповнює.

У розділі «Інфотека» подано інформацію про публічні заходи, присвячені темі астроном-мічної освіти, а також про підручники, посібники, наочні засоби навчання, періодичні видання та ресурси мережі Інтернет, які можна використати для астроосвіти. Всі ці ресурси перевірено щодо їх змісту й відповідності навчальним програмам з астрономії, що $€$ чинними в Україні.

Цей розділ містить низку підрозділів: публічні заходи (про семінари з питань астрономічної освіти, а також про науково-популярні та пізнавальні лекції); навчальні програми, підручники, книжки та періодика (перелік джерел з означених питань): окремі статmі та мультимеdia (статті з різних питань астрономії та з питань астрономічної освіти і популяризації астрономії; покликання на ютуб-канал «Все про Всесвіт», де вміщено пізнавальні та навчальні матеріали з астрономії; інформація про електронні підручники, наочні засоби навчання і навчальні фільми); інтернет-ресурси (покликання на джерела, присвячені питанню астро- 
номічної освіти, астрономічних новин, астрономічних зображень, а також інтернет-адреси обсерваторій і телескопів).

У розділі «Планетарій» ідеться про, можливо, найкращий засіб наочності для навчання астрономії. Таким $€$ планетарій. Ще років 10-15 тому, говорячи про планетарій, мали на увазі культурно-просвітницьку установу, де спостерігали зоряне небо, штучно створене спеціальним апаратом. Нині вже $є$ цифрові, електронні, індивідуальні, надувні тощо планетарії. Тобто нині $€$ засоби, що дають змогу як вчителю, так і учневі, без особливих зусиль показати (подивитися) створене штучно зоряне небо: чи то на моніторі персонального комп'ютера, чи на екрані.

Такі засоби уможливили, хоча й неповною мірою, розв'язати давню методичну проблему, пов'язану з навчанням астрономії, - йдеться про навчальні астрономічні спостереження. Серед них заслуговує на увагу комп'ютерна програма «Stellarium» (рис. 5). Методичні рекомендації та поради щодо роботи з нею «Як працювати з електронним планетарієм «Stellarium»» вміщено за покликанням (https://bit.ly/3vYrJnT).

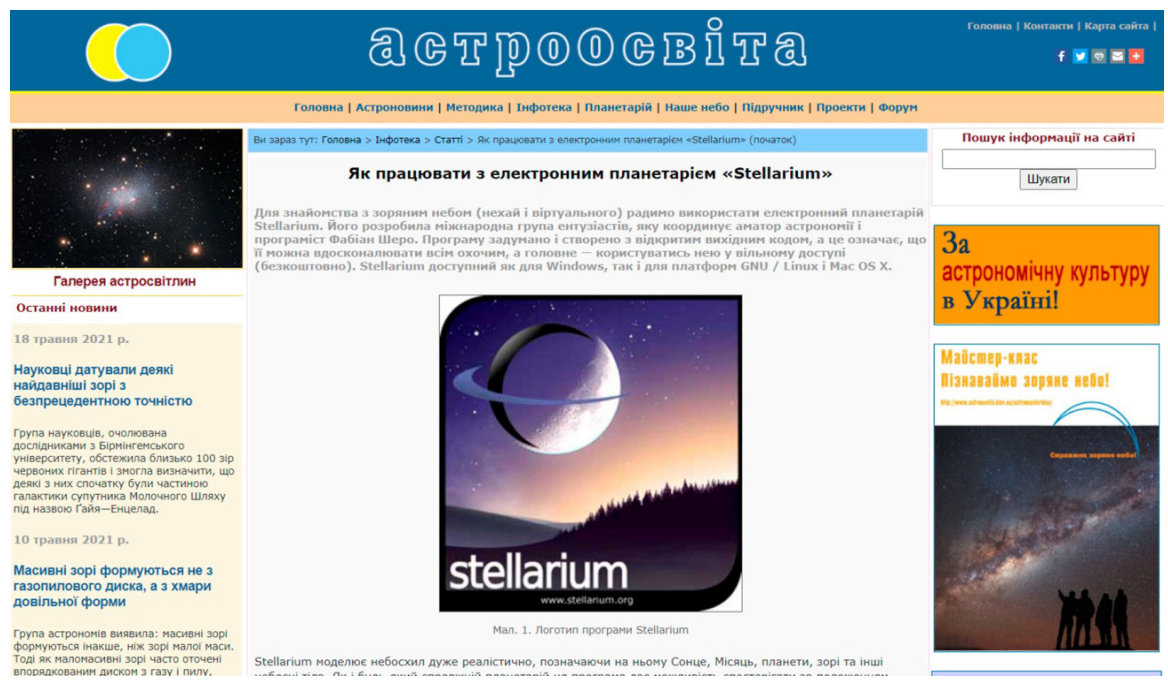

Рис. 5. Перша сторінка сайту «Астроосвіта» 3 методичними рекомендаціями та порадами щодо роботи з електронним планетарієм «Stellarium»

Для ознайомлення учнів із виглядом зоряного неба в різні пори року вчитель може також скористатися «Коротким путівником зоряного неба» (https://bit.ly/3dlHWN9).

Особлива роль на сайті «Астроосвіта» належить розділу «Підручник», адже тут подано докладну інформацію про підручник профільного рів- 
ня для 11 класу за навчальною програмою авторського колективу під керівництвом Я.С. Яцківа, що побачив світ у видавництві «Педагогічна думка» (автори М.В. Головко, І.П. Крячко, URL : https://bit.ly/3qzMTY4).

Підручник відкриває навчальний матеріал розділу «Зорі». Попередні розділи, згідно з навчальною програмою, «Зоряне небо та рухи світил», «Методи та засоби астрономічних досліджень» і «Сонячна система» викладено у підручнику для 10 класу.

У розділі «Підручник» також подано інформацію про навчальний посібник з астрономії для 10-11 класів загальноосвітніх навчальних закладів, який створено за навчальною програмою «Астрономія. 1011 класи. Курс за вибором» видання 20128 р. (автори М.В. Головко, І.П. Крячко) (рис. 6).

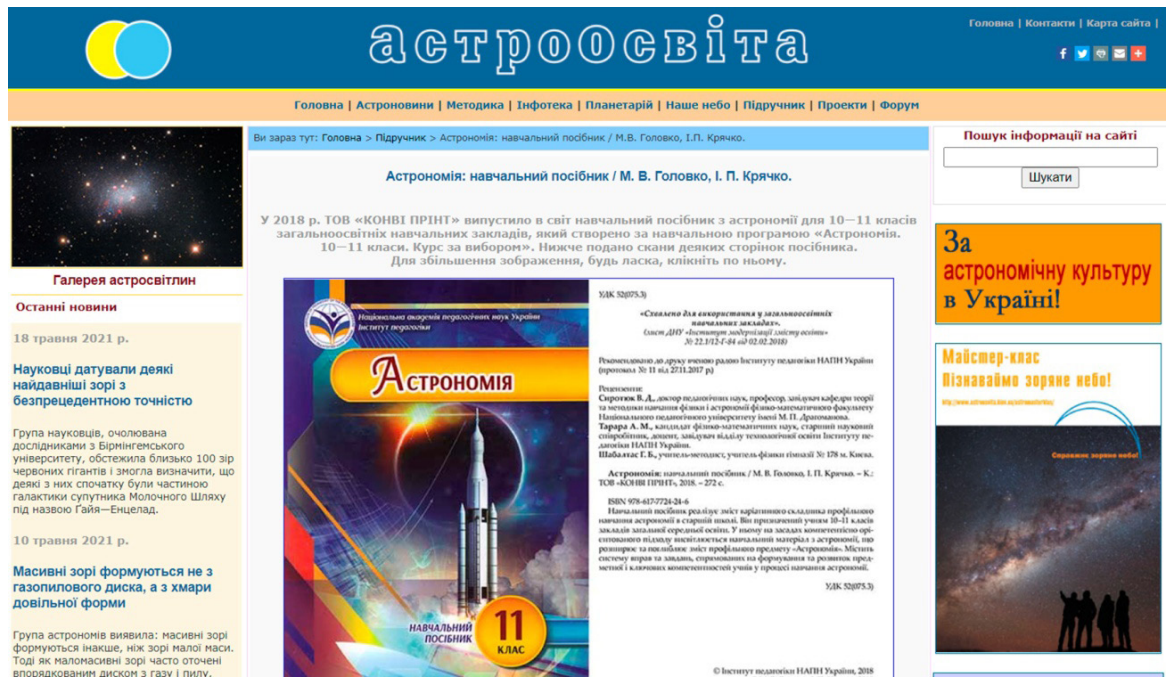

Рис. 6. Сторінка сайту «Астроосвіта» з інформацією про навчальний посібник «Астрономія» для 1011 класів загальноосвітніх навчальних закладів

Навчальний посібник реалізує зміст варіативного складника профільного навчання астрономії в старшій школі. Він призначений учням 10-11 класів закладів загальної середньої освіти. У ньому на засадах компетентнісно орієнтованого підходу висвітлюється навчальний матеріал з астрономії, що розширює та поглиблює зміст профільного предмету «Астрономія». Містить систему вправ та завдань, спрямованих на формування та розвиток предметної і ключових компетентностей учнів у процесі навчання астрономії. 
На сторінці http://www.astroosvita.kiev.ua/pidruchnyk/astronomiia-10$11 \mathrm{kl}$-posibnyk.php вміщено покликання на pdf-файл цього навчального посібника. Його можна завантажити й вільно використовувати для навчання чи вивчення астрономії.

Серед матеріалів, уміщених в розділі «Проекти», заслуговує на увагу інформація про Всеукраїнську учнівську олімпіаду з астрономії (http:// www.astroosvita.kiev.ua/proekty/astroolimpiada/olimpiada_astroedu.php) (рис. 7). Для дистанційного навчання астрономії корисними є завдання і задачі, які розв'язували учасники цієї олімпіади. Наприклад, завдання і задачі IV етапу IV Всеукраїнської учнівської олімпіади з астрономії вміщені на цій сторінці: https://bit.ly/3w48ppl.

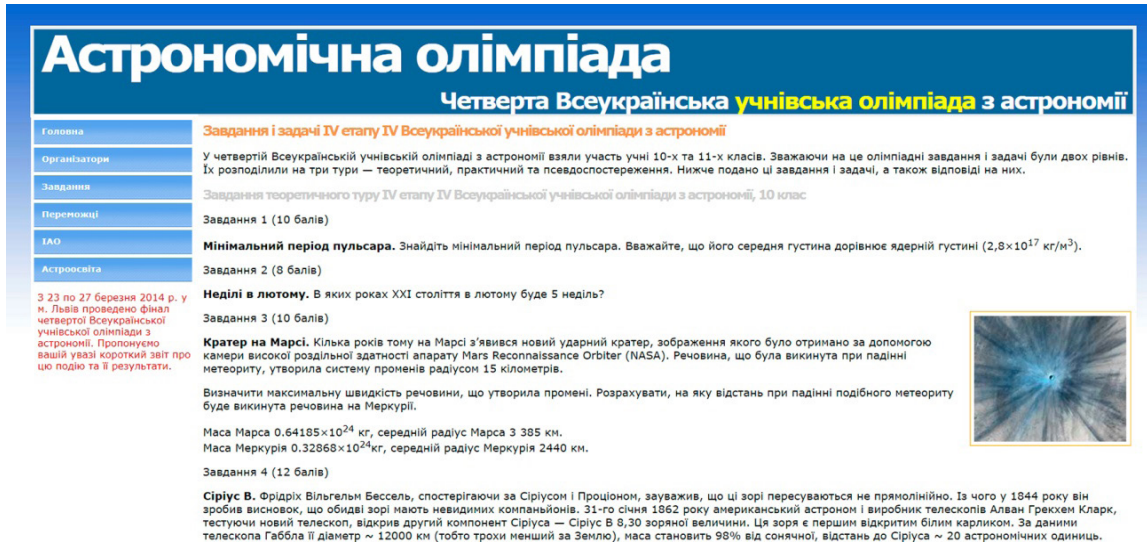

\section{Рис. 7. Знімок з екрана сайту «Астроосвіта», де вміщено завдання} і задачі IV етапу IV Всеукраїнської учнівської олімпіади з астрономії.

На сайті «Астроосвіта» вчитель знайде інформацію про конференції, присвячені питанням астрономічної освіти, докладні розповіді про Міжнародний рік астрономії та Астрономічний педагогічний фестиваль, який було проведено в Україні з нагоди цієї непересічної події в історії астрономії, а також про безстрокову науково-просвітницьку програму «За астрономічну культуру в Україні!» і майстер-клас «Пізнаваймо зоряне небо!».

3 огляду на завдання організації дистанційного навчання доцільно звернути увагу на роботу зі створення в Україні астрономічного науково-освітнього інформаційного середовища засобами інформаційно-комунікаційних технологій. Вже нині, крім сайту «Астроосвіта», діють окремі його складові, зокрема «Український астрономічний портал» (http://www.astrosvit.in.ua/), науково-популярний астрономічний інтернет-журнал для широкого загалу «Наше небо» (http://www.nashenebo. 
in.ua/index.php) та ютуб-канал «Все про Всесвіт» (https://www.youtube. com/channel/UCyOYQ1meDg7R5SKFMXeXySg).

Зазначені ресурси містять великий обсяг інформації, яку можна використати для цілей дистанційного навчання астрономії.

\subsection{3. Особливості дистанційного навчання географії}

Дистанційне навчання дасть результати, лише якщо буде посильним для всіх учасників освітнього процесу. Проводячи педагогічні розвідки щодо дистанційної освіти, наукові співробітники відділу навчання географії та економіки виявили певні недоліки та переваги. Залучивши до опитування (через анкетування) експериментальні заклади загальної середньої освіти, були зроблені такі висновки. Карантинні умови виявили низький поріг стресостійкості серед учнів, батьків та вчителів (нервові зриви, небажання слухати в незвичному режимі навчальний матеріал, непорозуміння з дітьми тощо).

Неможливість якісно засвоїти навчальний матеріал (перевагу учні віддають все ж таки власному вчителю, до манери якого звикли, ніж вчителю на екрані в онлайновій школі, несприйняття нових форм подання навчального матеріалу, неможливість вести дискусію тощо).

Потужне емоційне вигорання (у вчителів - професійне - нерозуміння, де шукати українськомовну інформацію, яким чином контролювати отриманні знання учнів, постійно бути на зв'язку з учнями та їх батьками; в учнів - відсутність навчальної мотивації, небажання самоорганізовуватись, самостійно видобувати пізнавальну інформацію тощо; у батьків - незнання психологічних особливостей навчання, невміння організовувати дитину, відсутність дисципліни тощо).

Брак чітких рекомендацій увів з перших днів у ступор всіх, щоправда, найбільш креативні вчителі, які вже мали досвід змішаного навчання та навчання в умовах карантину, об'єднали (або вони вже були об'єднані) учнів у вайбер-групи та Інстаграм.

Поява телешколи спонукала вчителів до активізації в розробленні власних уроків через Skype, Classroom, Classtime.

Специфічність навчального предмету географія, що потребує декілька джерел інформації, а саме картографічних, спричинила неабияку складність, оскільки не всі змогли опанувати GPS технології.

Географічна інформація дуже лабільна (кількість населення, стан довкілля, ресурсозабезпеченість, глобальні проблеми людства, «гарячі точки» тощо), а відсутність українськомовних сучасних даних створювали перешкоди для вчителів, особливо віком 50+, оскільки не всі вчителі географії вільно володіють англомовними інтернет- ресурсами. 
За невміння або небажання самоорганізовуватися, вчителі зазначали, що з часом учні стали більш відповідальними і самостійно знаходили пізнавальну інформацію, таким чином недолік став перевагою.

Під час опитування батьки зазначали, що, незважаючи на те, що географія був для них улюбленим предметом у школі, під час карантину вони пізнали багато нових та цікавих фактів та багато чого навчились разом з дітьми. Щоденна демонстрація географічних карт щодо розповсюдження Covid-19 в світі, в Україні та Києві мотивувала учнів та їх батьків більш уважно ставитися до картографічної інформації.

Співробітники відділу були активно залучені до заходів, щоб проводились МОН України, дистанційно брали участь у створенні типових освітніх та модельних програм. Протягом навчального року виступали на різних платформах та перед різними аудиторіями щодо розв'язання проблеми ефективного проведення уроків в режимі дистанційної освіти, самі проводили уроки та проводили майстер-класи перед вчителями географії в рамках курсів підвищення кваліфікації в обласних інститутах післядипломної педагогічної освіти (Закарпатська, Івано-Франківська, Хмельницька, Одеська, Житомирська, Полтавська, Київська області та Київ тощо).

Відділ навчання географії та економіки Інституту педагогіки НАПН України пропонує науково- та навчально-методичну підтримку закладів освіти різних рівнів у дистанційному режимі. На електронних ресурсах відділу (https://bit.ly/3wcyxhP) розміщені розробки наукових співробітників з методичними коментарями з метою їх використання в організації дистанційного навчання здобувачів різних рівнів освіти та методичної підтримки вчителів географії та економіки, а також викладачів закладів вищої освіти, які викладають курс методика навчання. Із питань науково-методичного супроводу загальної середньої освіти на сайті Інституту педагогіки та Електронної бібліотеки НАПН України відповідні матеріали згруповані за видами продукції (концепції, навчальні програми курсів за вибором, монографії, методичні та практичні посібники з методики навчання географії, методичні рекомендації, підручники тощо) (https:// lib.iitta.gov.ua/view/divisions/geed/).

Умови дистанційного навчання змусили всіх учасників освітнього процесу шукати нові підходи та методи під час підготовки до уроків 3 географії та курсів 3НО. Щоб допомогти учням краще запам'ятати матеріал, в ліцеях, гімназіях та загальноосвітніх закладах використовуються різноманітні інтерактивні сервіси з географії. На курсах 3 HO Educator та під час проведення онлайн-уроків вчителі географії часто використовують означені сервіси, учням подобається! Сервіси Google - від Google 
Maps та Street View до Arts\&Culture - можна використовувати для закріплення матеріалу з багатьох тем. Earthcam.com - на порталі зібрана колекція вебкамер встановлених у всіх містах світу, від США до Таїланда. Можна використати в 10-му класі при розгляді країн та регіонів. 7 чудес України - всеукраїнський просвітницький проєкт. Його задум показати Україну в аспекті непересічності та унікальності у природному та історико-культурному форматі. А головна мета - формування привабливості країни як для зовнішнього, так і внутрішнього туризму. Відеофільми можна показувати учням на уроках в межах програми 8-9-х класі. Seterra Online - одна з найбільш захопливих та популярних географічних вікторин у світі. Граючись, можна у цікавий спосіб запам'ятати розташування країн та їх столиць, пам'ятки, прапори, номенклатуру від найбільш визначних географічних об`єктів до найдрібніших. Ця програма підійде для засвоєння таких категорій знань: материки та частини світу; найбільші країни в світі або в межах окремого материка; столиці країн і найбільші міста; річки; озера, моря; острови; прапори окремих краї Ethermap - достатньо новий інструмент, який можна використовувати для створення онлайн-карт. Тут можна обмінюватися картами, вносити доповнення, редагувати все, просто надавши учням покликання. Можна запропонувати учням створити разом карту чудових місць для прогулянок в будь-якому місці, написати про все коротку інформацію та додати фото. Атлас пазлів National Geographic. Кожна з колекцій пазлів $€$ онлайн-картою континенту або країни. Тут дуже багато цікавих карт та неймовірних історій. Їх можна використати на закріплення навчального матеріалу з різних тем для учнів 6-11-х класів.

На порталі Національного географічного товариства представлено великий вибір інтерактивних завдань. Зокрема, карти, з допомогою яких можна здійснювати віртуальні мандрівки. У цьому ж розділі Earthpulse ознайомлює нас з проблемами населення. Ресурс можна використати в 8-му класі при розгляді теми «Населення світу». Запущена бета-версія National Geographic Education, де $\epsilon$ величезна колекція відео та фотоматеріалів. Передусім, у нагоді стане конструктор інтерактивних карт. Використовуються добірки різних онлайн-ресурсів з готовими презентаціями та відео для полегшення опрацювання тем учнями.

У межах угоди між відділом навчання географії та економіки Інституту педагогіки НАПН України та Деснянським управлінням освіти в місті Києві та в зв'язку із запровадженням карантинних заходів задля запобігання поширення на території України короновірусу COVID19 на замовлення районного науково-методичного центру завідувачкою відділу був проведений on-line урок для 10 го класу з теми «Америка: природні умови 
та ресурси, населення», як співавтор підручника, за яким навчається більшість шкіл Деснянського району міста Києва. Підручник розміщено на сайті електронної бібліотеки НАПН України http://lib.iitta.gov.ua/9489/ Сам урок можна подивитися за покликанням (https://drive.google.com/ open).

Наукові співробітники відділу навчання географії та економіки Інституту педагогіки НАПН пропонують науково- та навчально-методичну підтримку закладів освіти різних рівнів у дистанційному режимі (https:// lib.iitta.gov.ua/view/divisions/geed/).

А також долучились до створення інтерактивних географічних карт за допомогою співробітників Інституту передових технологій та інтерактивних завдань (https://geographer.com.ua/book).

Для забезпечення дистанційного навчання використовувались власні вебресурси (блоги, соціальні мережі, електронна пошта, інструменти цифрового навчання: https://miyklas.com.ua/, www.edmodo.com); Google-сервіси (Classroom) або веб-ресурс закладу освіти. Якщо в класі невелика кількість учнів й існує можливість спілкування в реальному часі, пропонувалось використати можливості скайп-зв'язку, як для проведення навчальних занять, так і надання окремих консультацій. Для проведення онлайн-зустрічей з більшою кількістю учнів (уроки, лекції, вебінари, індивідуальне й групове консультування та інші форми взаємодії зі здобувачами освіти), краще скористатися можливостями Zoom або Google Meet.

Основою дидактичного забезпечення дистанційного навчання географії та економіки є підручники, робочі зошити, матеріали, розроблені вчителями та методистами, які можна підібрати на відповідних електронних освітніх ресурсах (https://naurok.com.ua/, https://osvitoria. media/, http://metod-bank.com.ua/, https://learningapps.org/, https:// www.classtime.com/uk/, http://prosvitcenter.org/, http://virtualschool.org. ua, http://disted.edu.vn.ua/ тощо).

Для інтерактивного опитування школярів дуже зручною є платформа Classtime. Classtime - це онлайн-сервіс для миттєвої перевірки навчальних досягнень учнів за допомогою тестів. Такі тестування можна проводити як в синхронному так і в асинхронному режимі. Цей сервіс доступний українською мовою і має зручний інтерфейс. Також для організації дистанційного навчання учнів нами пропонувалось використовувати й інші освітні вебресурси та онлайн-платформи, віртуальні класні кімнати, мультимедійні матеріали, навчальні відеофільми, відео- та аудіозаписи лекцій, семінарів тощо, інтерактивні вправи, «віртуальні дошки». Для отримання зворотного зв'язку використовували електронну 
пошту, онлайн-тестування тощо. Google Планета Земля (https://www. google.com.ua/intl/uk/ earth/). До роботи з цим ресурсом учитель може надати інструкції учням: перейдіть в режим «Перегляд вулиць» і прогуляйтеся будь-яким маршрутом; у шар Voyager, щоб побачити знімки нашої планети, зроблені професійними фотографами SesameStreet, BBC Earth, HACA й іншими партнерами Google. За допомогою інструментів сервісу можна визначати географічні координати об'єктів, їх висоту над рівнем моря, відстані між об'єктами та зробити інші вимірювання.

Windy (https://www.windy.com/) - незвичайний інструмент для візуалізації прогнозу погоди. Учитель має пояснити учням, що коли вони спостерігають тропічний шторм або можливу сувору погоду, планують поїздку, займаються спортом на відкритому повітрі або їм просто потрібно знати, чи буде дощ у ці вихідні, Windy надасть найактуальніший прогноз погоди. Унікальність Windy полягає в тому, що він надає об'єктивну і релевантну інформацію. Потужна плавна презентація робить прогноз погоди справжнім задоволенням.

Оцінювання навчальних досягнень учнів із географії здійснюється з урахуванням їхніх індивідуальних особливостей і передбачає диференційований підхід щодо його організації. Критерієм оцінки роботи учнів $€$ не стільки обсяг навчального матеріалу, що залишився в пам'яті, скільки вміння його аналізувати, узагальнювати, установлювати причинно-наслідкові зв'язки, використовувати в життєвих ситуаціях, уміння самостійно здобувати знання. При цьому важливо під час вивчення географії особливу увагу приділити мотивації: авансуванні успіху, спонуканню до самоаналізу, самооцінці, самопізнанню, інтенсифікації того змісту навчального матеріалу, який має особистісне значення для учнів. Різниця в оцінюванні завдань однакового рівня складності може бути зумовлена якістю їх виконання, але не їх відмінністю між собою. В організації оцінювання виконаних робіт потрібно передбачити частку, яка відповідає якості оформлення роботи, наприклад - 2 бали. При цьому обов'язковим $€$ попереднє пояснення вимог до оформлення, зокрема використання кольорів (тільки робочих - синього й червоного - чи й інших), шрифтів, малюнків, символів тощо.

В організації дистанційного навчання з усіх предметів, у тому числі й з географії, $\epsilon$ низка проблем, які ускладнюють роботу і вчителя, й учнів. Це недостатнє технічне забезпечення(недостатня кількість гаджетів в сім'ї, коли всі працюють або навчаються дистанційно), недостатня потужність інтернету (якщо учні або вчителі в умовах карантину знаходяться за містом, у віддалених регіонах це унеможливлює використання сервісів та платформ), слабка підготовка вчителів та учнів щодо вико- 
ристання платформ, сервісів, значне перевантаження роботою вчителів (вчителю доводиться навчатися самому, навчати учнів, організовувати навчання, готувати навчальні матеріали, перевіряти надіслані роботи, готувати та проводити відео уроки - тобто навантаження значно збільшується), перевантаження учнів (перегляд та вивчення навчального матеріалу, виконання завдань згідно розкладу, участь у відео консультаціях, багато часу біля гаджетів, недотримання санітарних норм). Проблемою є також об'єктивне оцінювання знань учнів, адже підготовані тести, перевірочні роботи учні виконують за допомогою різних джерел знань, спілкуються між собою, списують, і проконтролювати це не можливо. Досить складно провести онлайн-опитування, в якому бере участь 36 учнів класу, онлайн тести, коли задається конкретний час здачі тесту. Альтернативним варіантом оцінювання знань з географії може бути підготовка завдань, відповіді на які не знайдеш в інтернеті, мається на увазі завдання на виявлення закономірностей, здійснення аналізу, формування висновків, встановлення причинно-наслідкових зв'язків, підготовка таких завдань вимагає від вчителя ще більше часу на роботу, а потім через Google формі у вигляді тестів перевіряти, але реальне оцінювання вивченого матеріалу можливе лише після карантину на основі написання контрольних, підсумкових робіт.

3 урахуванням специфіки географії як навчального предмету найбільш ефективною виявилась платформа Google for Education, зокрема, їі частина Google Classroom, що забезпечує можливість організації роботи 3 картами, діаграмами, таблицями, статистичними матеріалами, роботи в групі та задля виконання спільних проектів, обговорення певного дискусійного питання офф-лайн та онлайн, обмін та обговорення відео та аудіо уроків; створення електронних тестів та інших інтернет-ресурсів тощо.

Серед додаткових ресурсів для ефективного навчання географії були залучені сервіси Learning Apps та Classtime. Learning Apps - це онлайн конструктор для розробки, зберігання інтерактивних завдань з географії, за допомогою яких учні можуть перевірити і закріпити свої знання в ігровій формі. Сервіс працює декількома мовами, зокрема й українською. Classtime - це онлайн-сервіс електронних тестів, що збагачує лекції з географії миттєвою візуалізацією рівня розуміння та прогресу всіх учнів у реальному часі.

Через складні умови роботи все ж таки вдалося навчити учнів самостійно здобувати знання, самоорганізовуватися (найбільш відповідальні робили це самостійно, інші - за допомогою батьків). Умова успіху чітка організація учнівського колективу, уміння учителя користуватися методикою організації та використання платформи Google Classroom, 
можливість урізноманітнювати навчальний та контрольний матеріал для наповнення файлів.

Серед недоліків та проблем визначаємо різні соціально-економічні умови в яких перебувають учасники освітнього процесу, як вчителів, учнів та їх батьків були нерівні можливості забезпечувати дистанційне навчання якісно, оскільки велика кількість опитаних мають рівень життя - трохи вище за злидня (один комп'ютер на родину з трьох дітей, відсутність смартфону, відсутність Wi-Fi, тощо). Не вдалося урізноманітнити науково-географічні відеоматеріали, особливо українськомовні, та відсутність відеоматеріалів, що орієнтовані на вікові особливості учнів (особливо шестикласників) в процесі опрацювання ними відповідних тем. Практично знівелювалась екскурсійно-дослідницька робота під час дистанційного навчання. Проблеми виникали через відсутність електронної документації в навчальному закладі. Оскільки рішення щодо введення карантину було прийнято за декілька днів, адміністрація та вчителі шкіл не встигли забезпечити вільний доступ до паперових журналів. Для того, щоб дистанційне навчання стало органічним продовженням традиційного навчання, першочергово, слід забезпечити вільний доступ учнів, батьків та вчителів до електронних журналів. Наприклад, Всеукраїнська освітня платформа «Atoms», під грифом Міністерства освіти та науки України, пропонує безкоштовне підключення системи електронної документації для закладів освіти. Не вдалося у повному обсязі реалізувати завдання позакласної роботи, проектну діяльність, навчальні дослідження через обмеженість у просторі та часі.

За результатами дослідження щодо залучення суб'єктів освітнього процесу до дистанційного навчання виявлені такі тенденції: недостатня законодавча база України для широкого впровадження дистанційного навчання (не тільки в умовах карантину); недостатнє фінансування для забезпечення матеріальної бази закладів загальної середньої освіти та вчителів для впровадження дистанційного навчання; низьке фінансування на розвиток та впровадження дистанційних технологій у загальної середньої освіті (на відміну від вищої освіти); упередженість та консерватизм щодо дистанційного навчання як вчителів, так і керівництва шкіл та деяких управлінь освіти; недостатня державна підтримка розвитку дистанційної освіти в Україні; відсутність конкретної методики проведення занять, а відтак використання різних, іноді сумнівних моделей, технологій, форм організації та використання навчального предметного контенту, що може призводити до ускладнень в обміні позитивними 
результатами та досягненнями навіть при ефективній передачі навчальної географічної інформації.

Стрімкий розвиток диджиталізації, глобалізація ринку освіти та значна перевага продуктів та технологій дистанційного навчання, порівняно з вітчизняними, є джерелом нової і складної проблеми - міжнародної конкуренції освітніх установ, організацій та засобів. Враховуючи технічну відсталість України та фінансову кризу освіти, складно конкурувати із зарубіжними установами, які надають послуги дистанційного навчання. Крім того, в освітній процес активно впроваджується білінгвальне (багатомовна освіта) навчання: вільне володіння англійською мовою дає учням можливість відчувати себе комфортно в будь-якому мовному середовищі, і він радше буде дивитися якісний англомовний контент, чим заглядати на українські аматорські кейси.

3-поміж специфічних соціально-педагогічних проблем центральне місце займає протиріччя між темпами збільшення обсягів знань у суспільстві й обмеженими можливостями їхнього засвоєння особистістю. Людина, що не володіє інформаційними технологіями, позбавлена одного з адаптаційних механізмів у соціумі, який динамічно розвивається. Виникає проблема формування і розвитку інформаційної культури особистості через формування не тільки географічної, а ще й цифрової компетентності [55; 56; 100].

\section{4. ОСОБЛИВОСТІ ДИСТАНЦІЙНОГО НАВЧАННЯ МАТЕМАТИКИ}

Стан дистанційного навчання математики у 2020-2021 роках. Щоб вивчити проблеми, що виникали під час організації дистанційного навчання в умовах карантину, та створення в подальшому сучасного освітнього середовища, яке забезпечить умови, засоби і технології для організації системного дистанційного навчання математики, співробітниками відділу математичної та інформатичної освіти Інституту педагогіки НАПН України було проведено двічі опитування вчителів математики різних областей України. Перший раз опитування проводилось у травні 2020 року, коли вчителі вперше зіткнулись з труднощами організації дистанційного навчання, а другий раз - у травні 2021 року, коли вчителі вже мали попередній досвід.

Mema опитування - з'ясувати, яким чином було організоване дистанційне навчання математики в умовах вимушеного довготривалого карантину у 2019/2020 та 2020/2021 навчальних роках, які труднощі виникли в учителів, і прослідкувати, які зміни відбулись за рік. 
Засоби опитування - Google-форми, з якими можна ознайомитися за покликанням (https://docs.google.com/forms/d/e/1FAlpQLScvSArA V09mhfGZjLA7txz7zwpKs2kMYHOA3A6-ZIDJh4UAig/viewform?usp=sf_link та https://forms.gle/UaLA86WPwJjsFH67A).

У 2020 році вибірка - 953 вчителя математики, а у 2021 - 1060. Варто зауважити, що в опитуванні брали участь лише ті вчителі, що мають доступ до Інтернету.

Короткий аналіз результатів опитування відповідно до питань, що пропонувалися.

1. Чи проводили Ви онлайн-уроки (у режимі реального часу) з учнями під час дистанційного навчання?

\begin{tabular}{|ll|l|}
\hline 2020 рік & \multicolumn{2}{|c|}{2021 рік } \\
\hline & & \\
\hline
\end{tabular}

На діаграмах подане співвідношення між кількістю вчителів, які проводили синхронні онлайн-уроки, і тими, що такі уроки не проводили. Як позитивне можемо відмітити, що відсоток вчителів, що проводили синхронні онлайн-уроки, зросла з 79,3 \% до 97,3 \%.

2. Які сервіси Ви використовували для проведення онлайн-уроків (у режимі реального часу)?

Учителям пропонувалися такі варіанти відповіді:

Zoom, Skype, GoogleMeet, Microsoft Teams, уроки онлайн не проводили, інше.

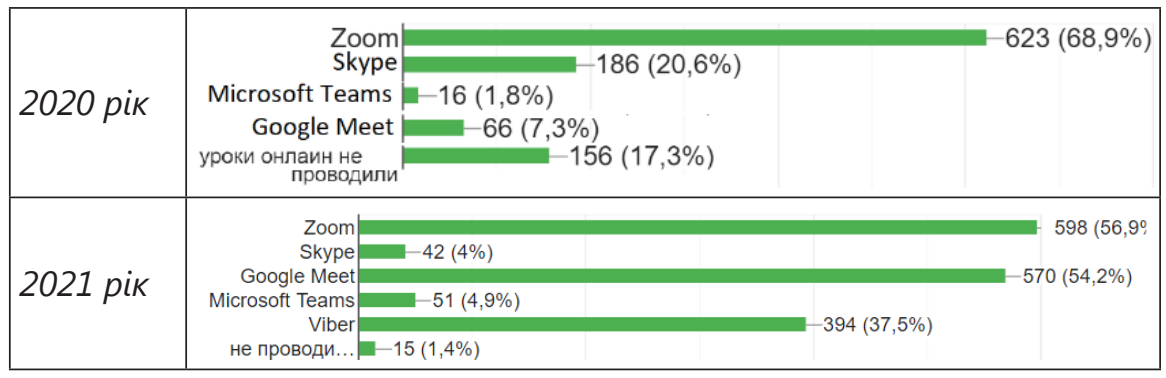


На діаграмах показано, як розподілився вибір учителів стосовно сервісів для проведення уроків онлайн. Учителі мали можливість указати кілька сервісів, якими вони користувалися. Найбільш активно вчителі використовують Zoom. Друге місце у 2020 році посідав Skype (понад $20 \%$ ), але в 2021 році його замінив GoogleMeet (54,2 \%). Опитування показало, що вчителі також активно використовують Viber у спілкуванні з учнями, а також деякі вчителі (менше 1 \%) використовують інші сервіси, а саме: Instagram, Jitsemeet, Discord, MyOwnConference, Liveboard, Miro, BitPaper, Classkick тощо.

3. Якою була тривалість одного уроку онлайн (у режимі реального 4acy)?

\begin{tabular}{|l|l|l|}
\hline \multicolumn{2}{|c|}{2020 рік } & 2021 рік \\
\hline 40 хв & уроки не проводили & \\
\hline
\end{tabular}

На діаграмах зображено розподіл тривалості онлайн-уроків математики. Більшість опитаних учителів проводили уроки математики, що тривали 40 хвилин. Ймовірно, це пов'язано з часом використання безкоштовної версії Zоom. Але спостерігаємо позитивну тенденцію до зменшення тривалості онлайн-уроків до 20-30 хв. Дистанційне навчання не тотожне традиційному. Під час дистанційного навчання доцільно більшу увагу приділяти самостійній роботі учнів. Саме тому в умовах дистанційного навчання вчителям математики бажано було спланувати роботу таким чином, щоб частину матеріалу учні опановували самостійно, а рівень розуміння та засвоєння навчального матеріалу визначався за допомогою спеціальних тестів. Під час зустрічей у режимі реального часу вчителі мають допомогти учням систематизувати вивчений матеріал, розібрати проблемні питання та важчі завдання, надати потрібні консультації тощо. Це зменшує емоційне та фізичне навантаження на учнів і вчителів, що зумовлюється особливостями електронних засобів навчання та взаємодією суб'єктів освітнього процесу в режимі онлайн. Надзвичайно продуктивно за таких умов використовувати технологію «Перевернутого класу». 
4. Кількість онлайн-уроків.

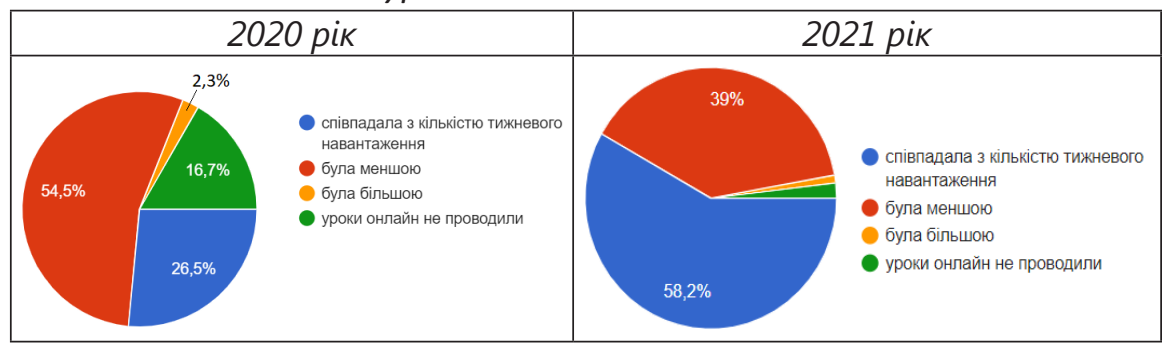

Діаграми відображають співвідношення між кількістю запланованих у календарному плані уроків і проведених синхронно.

У 2020 році 54,5 \% вчителів провели менше синхронних онлайн-уроків, ніж було заплановано в календарному плануванні. У 2021 році спостерігаємо тенденцію до проведення такої ж кількості синхронних уроків, як і заплановано. Насправді інтенсифікація процесу навчання за рахунок правильної організації дистанційного навчання дає можливість зменшувати кількість уроків математики на тиждень. Але враховуючи, що вчителі і учні лише вчаться працювати в цьому форматі, то поки що спостерігаємо картину, коли кожен учитель намагається використати по максимуму час, що може бути відведений на комунікацію всіх учасників навчального процесу. Також на ці дані може впливати концепція навчального закладу та здійснення контролю з боку адміністрації за роботою вчителів.

5. Часу на підготовку до уроку в режимі дистанційного навчання витрачали:

1) більше, ніж зазвичай; 2) менше, ніж зазвичай; 3) стільки ж; 4) уроки онлайн не проводили.

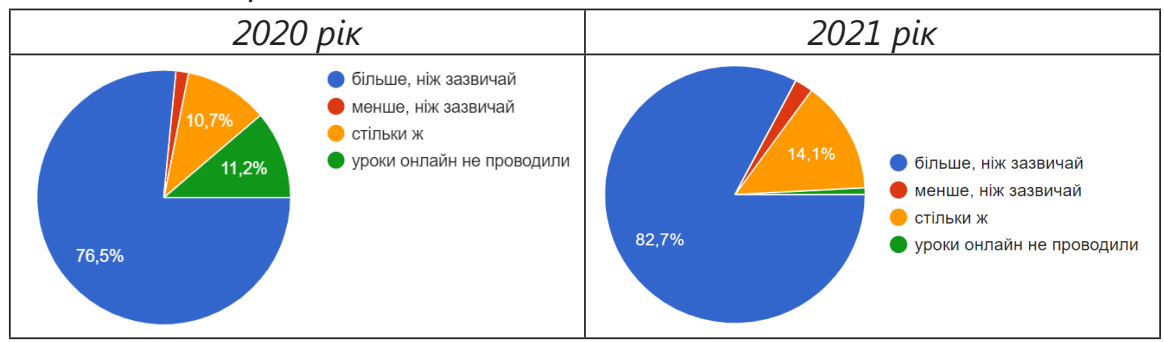

Дані діаграм яскраво свідчать про те, що вчителі математики під час дистанційного навчання на підготовку уроків витрачали більше часу, ніж це робили в умовах традиційного навчання.

В особистих бесідах з учителями нами з'ясовано, що ще більше часу витрачалося на перевірку різного роду учнівських робіт. 
Ураховуючи зменшення кількості вчителів, що не проводили онлайн-уроки, і збільшення кількості вчителів, що витрачають стільки ж часу на підготовку онлайн-уроку, як і на підготовку традиційного уроку, можемо говорити, що вчителі поступово опановують цю технологію.

6. Під час дистанційного навчання Ви використовували:

1. тестові оболонки та платформи, де доводилося самому заповнювати контент;

2. готові рішення (онлайн-курси, уже створені уроки чи завдання на різних платорормах тощо);

3. використовували відео з YоuTube;

4. спирались на матеріали "Всеукраїнської онлайн-школи», що транслювались по телевізору;

5. не використовували мультимедійний контент, працювали за підручником.

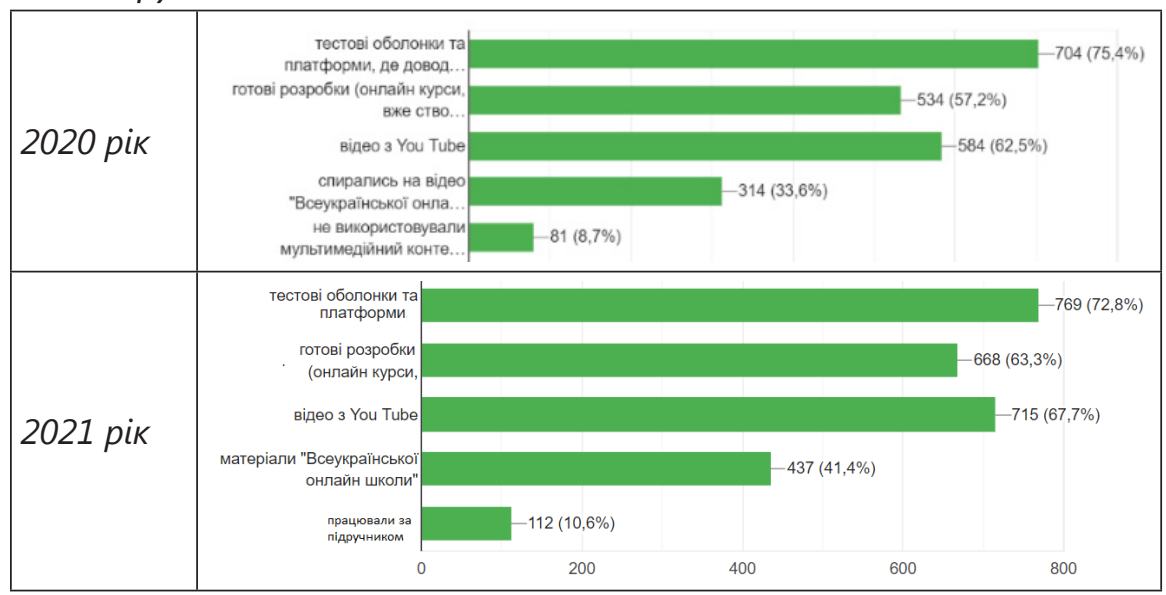

Результати опитування свідчать про той факт, що багато вчителів (біля 70 \%) створювали власний контент для організації дистанційного навчання та активно використовували готові відео з YouTube (близько $60 \%$ ). Бачимо, що, порівняно з 2020 роком (57,2 \%), більше вчителів використовували у 2021 році готові розробки (63,3 \%). У той самий час за рік ми не спостерігаємо стрімкого росту використання вже готових онлайн-курсів чи платформ для навчання математики, що дало б змогу вчителю зменшити час на підготовку до уроку. Це може бути також зумовлено не ознайомленістю вчителів з можливостями спеціалізованих платформ або ж незадоволенням контентом, що на них запропонований. 
7. Які платформи Ви використовували?

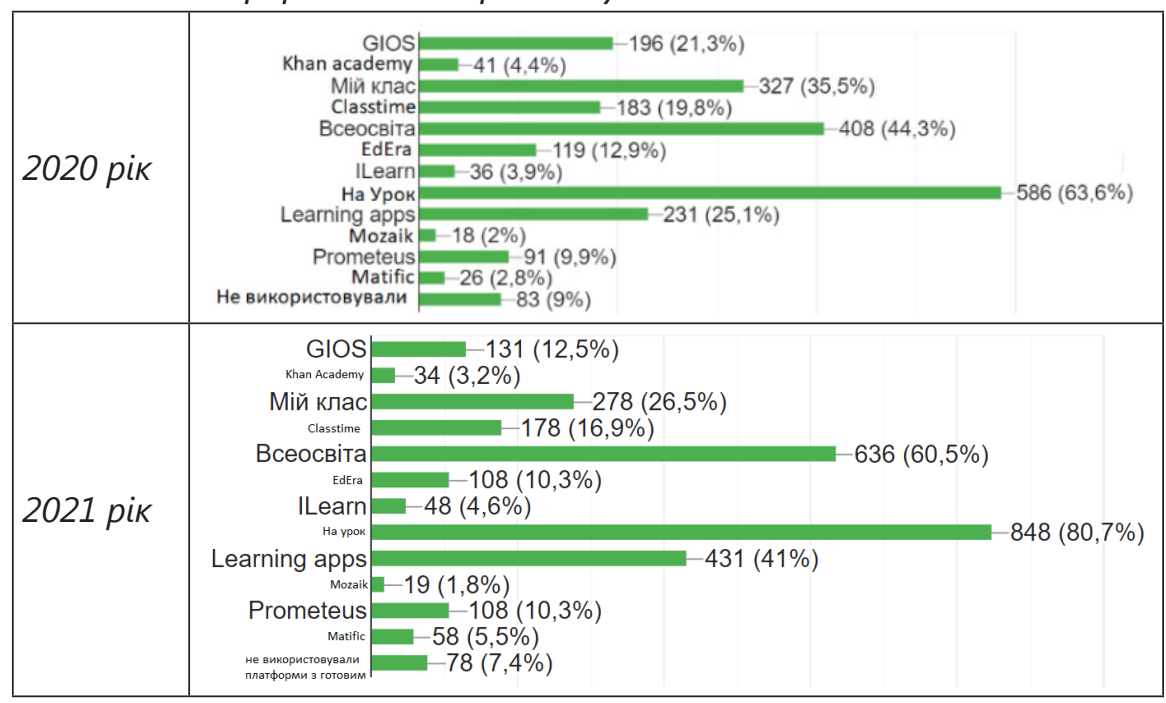

Учителям пропонувалося обирати серед таких платформ: GIOS, Мій клас, Classtime, Khanacademy, На урок, Всеосвіта, інше. Як видно з діаграм, найбільшою популярністю серед учителів користувалися такі платформи На Урок, Всеосвіта, Мій клас, LearningApps, Classtimei GIOS.

8. У якій формі Ви пропонували учням самостійні та контрольні робomu?

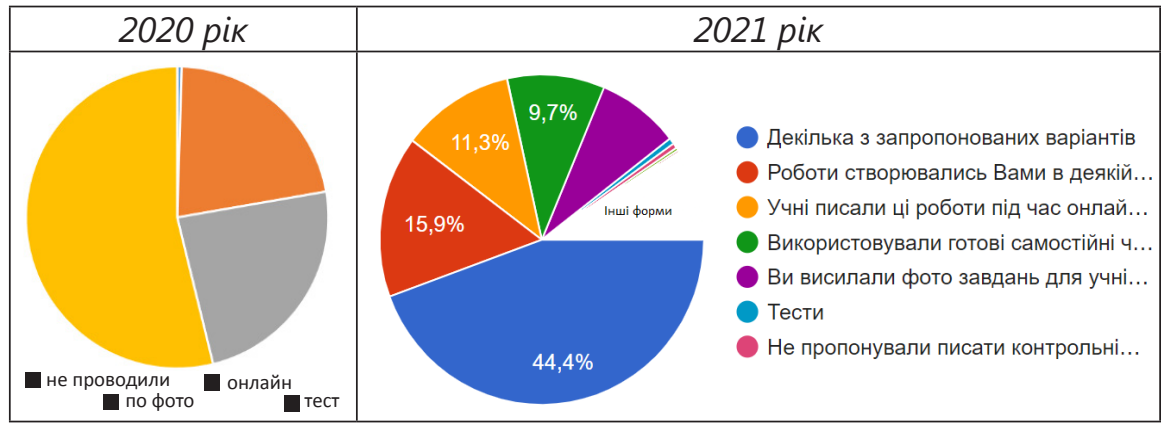

Результати опитування свідчать про те, що лише 0,5 \% вчителів не проводили контрольні чи самостійні роботи під час дистанційного навчання, а також про те, що в 2021 році вчителі використовували різні форми написання таких робіт (44,4 \%).

Решта вчителів проводили один із таких видів робіт:

- надсилали фото завдань для учнів, а учні у відповідь надсилали фото виконаної роботи (24,4 \% у 2020 році, 8,2 \% у 2021році); 
- створювались роботи в деякій тестовій оболонці, учням відводився час на їх виконання (52,9 \% у 2020 році, 15,9 \% у 2021 році);

- писали ці роботи під час онлайн-уроків у режимі реального час, а учні відправляли фотографії виконаної роботи відразу після завершення відведеного часу (22,2 \% у 2020 році, 11,3 \% у 2021 році).

У 2021 році 9,7 \% використовували готові самостійні чи контрольні роботи на різних ресурсах.

9. Чи перевіряли Ви засвоєння учнями теоретичного матеріалу?

На це запитання ствердно відповіли майже 80 \% опитаних учителів у 2020 році і $91 \%$ - у 2021 році.

10. Чи було відставання від програми?

На це запитання ствердно відповіли майже 74 \% опитаних учителів у 2020 році і $36 \%$ - у 2021 році. Бачимо, що у 2021 році вчителі змогли на основі попереднього досвіду правильно спланувати й організувати роботу з учнями.

11. Чи залишився час на повторення пройденого за рік?

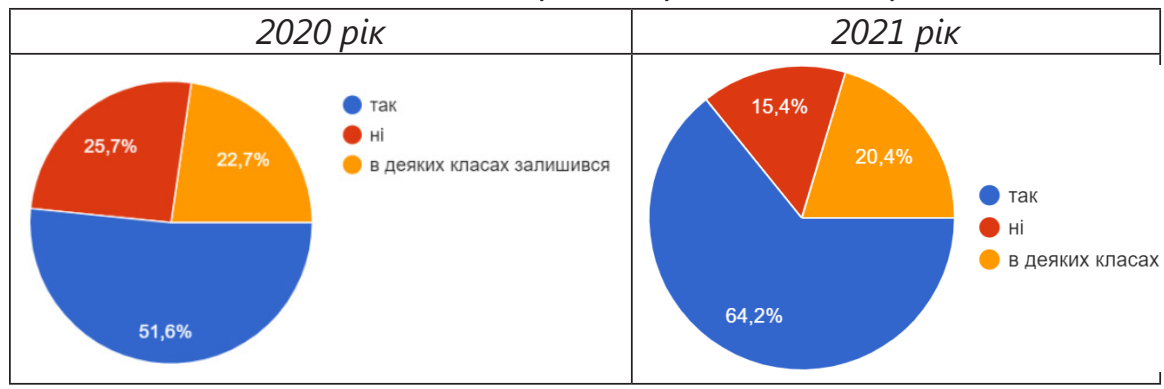

У 2021 році також зменшився відсоток учителів, у яких не залишилось часу для повторення матеріалу за весь рік.

12. Що змінилося у ставленні учнів до навчання в умовах дистанційного навчання?

Дистанційне навчання спричинило зміни у ставленні деяких учнів до навчання, до предмета, до вчителя. Більшість учителів зазначають, що внаслідок вимушеного карантину учні краще навчилися пристосовуватися до вимог освітнього процесу (близько $60 \%$ ), стали відповідальнішими (близько $40 \%$ ) та активнішими (близько $20 \%$ ). Суттєво підвищилася самоорганізація учнів (близько 55 \%). Варто зазначити, що для деяких учнів цей формат не підійшов, і учні навпаки втратили цікавість, мотивацію і перестали вчитися.

13. Які результати дистанційного навчання для Вас як вчителя?

Серед досягнень учителів математики за час карантину можна відмітити: 
- опанували нові форми роботи (близько 90 \%);

- підвищили рівень комп'ютерної грамотності (близько 70 \%);

- покращили атмосферу в класному колективі (близько 10 \%);

- покращили стосунки з батьками (близько 10 \%).

Водночас, за час вимушеного карантину вчителі надзвичайно втомилися, у багатьох погіршився стан здоров'я (особливо зір, постава).

14. У яких класах було найважче організовувати дистанційне навчання?

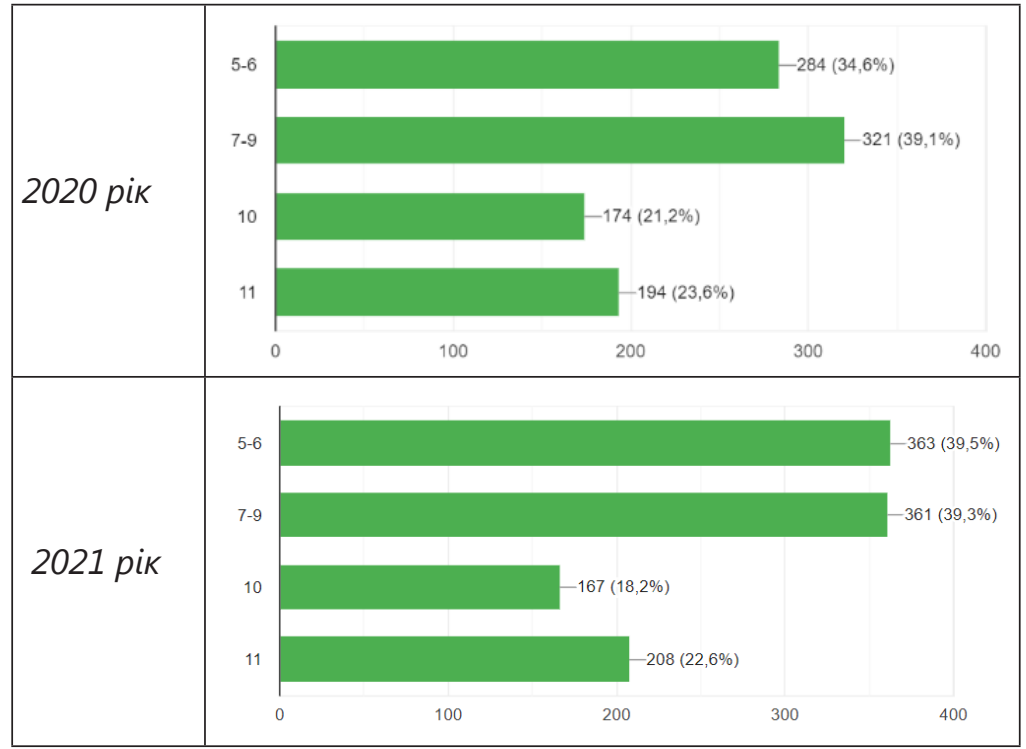

Як свідчать дані діаграм, найважче було організувати дистанційне навчання математики для учнів 5-9 класів. Це зумовлено віковими особливостями учнів.

15. Який з предметів важче було вивчати учням у форматі дистанційного навчання?

Як свідчать дані двох опитувань, більше половини вчителів не помітили різниці в організації навчання алгебри чи геометрії. Але близько 40 \% учителів вказали на те, що вивчення геометрії в дистанційній формі давалось важче, ніж алгебри. Це, скоріше за все, зумовлено тим, що розв'язування геометричних задач потребує здійснення побудов та обгрунтувань кроків розв'язання, що важко проконтролювати в онлайн-форматі.

16. Які труднощі Ви відчували під час дистанційного навчання?

Серед проблем, що виникали у процесі дистанційного навчання, вчителі зазначали: 
- технічні (відсутність гаджетів, низька якість Інтернету, неможливість учнів виходити на урок в режимі реального часу);

- неготовність учнів працювати самостійно;

- низька комп'ютерна грамотність учнів;

- нерівні умови навчання для дітей через різне матеріальне становище;

- неможливість єдиного вибору засобів навчання учнів навіть у межах одного класу;

- неможливість впливати на звуковий фон у квартирі під час уроку (утримувати увагу учнів дуже важко);

- ускладнена перевірка робіт (фото надзвичайно важко перевіряти);

- батьки активно брали участь у написанні різного роду робіт (важко сформувати реальну картину в класі, необ'єктивне оцінювання);

- брак часу для створення власного якісного контенту;

- багато звітів, що зменшує час на підготовку до уроків;

- недостатність емоційного контакту;

- відсутність редактора формул у тестових оболонках і конструкторах уроку.

У 2021 році до анкети було додане ще одне запитання: «Чи пройшли Ви за 2020-2021 навчальний рік якісь курси підвищення кваліфікації, що присвячені організації дистаниійного чи змішаного навчання?»

Як свідчать дані діаграми, вчителі відчували потребу поповнити свої знання щодо організації дистанційного (чи змішаного) навчання і $77 \%$ пройшли курси підвищення кваліфікації, присвячені цій тематиці.

Відповідно до результатів опитування можемо зробити такі ви-

\section{сновки.}

1. Основною проблемою органі-

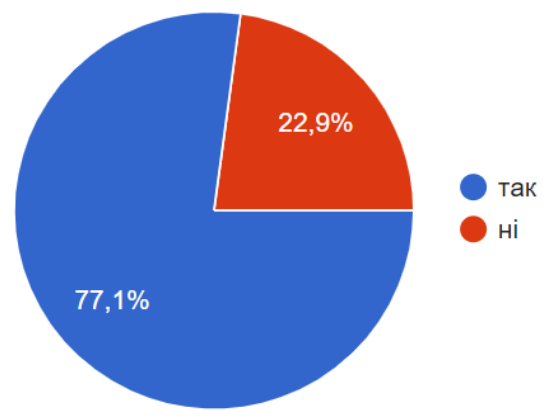

зації дистанційного навчання була відсутність у деяких учасників освітнього процесу гаджетів чи підключення до Інтернету. Навчальним закладам варто передбачити такі випадки і створити умови для надання вчителям гаджетів, потрібних для організації дистанційного навчання (можливо у тимчасове користування). Крім того, слід продумати можливості доступу до Інтернету.

2. Важко нівелювати роль батьків у дистанційному навчанні. Варто проводити інформування батьків, учнів і вчителів про можливості 
й переваги дистанційного навчання. Учителям проводити бесіди з батьками про допомогу в організації продуктивного дистанційного навчання. А ще краще повільно привчати учасників освітнього процесу до такого виду роботи за рахунок активного впровадження у практику змішаного навчання.

3. Незнання тайм-менеджменту, невміння самостійно організуватися та недостатність комунікації призводить до втрати мотивації в усіх учасників освітнього процесу. Тому спостерігається суттєве навантаження на нервову систему як учнів, так і вчителів. Відбувається виснаження кожного учасника процесу навчання (у тому числі й батьків).

4. Бажано було б автоматизувати якісь процеси навчання математики. Наприклад, чудово, коли вчитель іноді використовує готові ресурси, що є комплексними (забезпечують і подачу теоретичного матеріалу, і його закріплення). Ці ресурси мають надавати вчителям доступ до учнівських статистик. За таких умов виграють усі:

- учні самостійно за певним (визначеним учителем) алгоритмом проходять уроки;

- учителі не мають перевіряти кожну роботу учня, бо система це робить за нього, й учні відразу отримують зворотній зв'язок;

- учні й вчителі мають можливість швидко отримувати кількісну оцінку роботи учнів, аналізувати стан навчання та його динаміку.

Обираючи сервіси для організації дистанційного навчання, слід урахувати, що навчальні матеріали мають бути подані українською мовою й укладені відповідно до чинної програми. Причому краще, щоб вчителі могли оцінити переваги тих чи інших сервісів не в авральному режимі під час карантину, а під час традиційного навчання із залученням сучасних організаційних форм, зокрема змішаного навчання.

Організація дистанційного навчання математики. Дистанційне навчання математики проводиться з використанням різноманітних онлайн-сервісів. Застосування програмних засобів на різних етапах навчання можуть допомогти вчителю: у подачі нового для учнів навчального матеріалу; у формуванні навичок розв'язання різних завдань учнями; у перевірці якості засвоєння компетентностей учнів; у надані зворотного зв'язку чи організації комунікації з учнями; у творчій навчальній діяльності учнів на різних уроках. Розглянемо детальніше засоби, що можуть допомогти вчителю математики на кожному з цих етапах навчання. 
Подання нового навчального матеріалу. Під час викладу теоретичного матеріалу можна обрати декілька варіантів:

- виклад теоретичного матеріалу вчителем;

- самостійне опанування теоретичного матеріалу учнями;

- змішаний формат (частина матеріалу опрацьовується учнями самостійно, а частина за участю вчителя).

Одним із прикладів останнього варіанта $є$ виклад учителем оглядово всієї навчальної теми (наголос на основних поняттях та зв'язках між ними) з подальшим детальним самостійним вивченням учнями підтем. Або навпаки - попереднє самостійне опрацювання учнями теми з подальшим детальним розбором теоретичного матеріалу з учителем.

Вибір моделі опрацювання теоретичного матеріалу залежить від мети уроку й рівня підготовленості учнів класу.

Для того, щоб унаочнити та інтенсифікувати виклад нового навчального матеріалу вчителі вже звикли створювати презентації до уроків. Для цього достатньо розповсюдженим є програмний засіб PowerPoint. Бажано, щоб учителі завантажували свої презентації на Google диск чи трансформували їx y Google Презентації. У такому випадку в учнів вдома з'являється доступ до цих презентацій, тобто вони можуть за знайомими слайдами швидко відновити матеріал, про який йшлося на уроці. Учителі також можуть одразу створювати онлайн-презентації за допомогою Google Презентацій, Prezi (prezi. com) чи Sway (sway.office.com) і давати учням на них покликання для актуалізації вдома почутого на уроці.

Сучасному вчителю все частіше необхідно витримати конкуренцію 3 смартфоном і соціальними мережами, тож пасивне усвідомлення матеріалу швидко втомлює учнів. Свідома взаємодія з мультимедійним контентом у процесі навчання $€$ фактором підвищення навчальних досягнень учнів. Саме тому краще використовувати презентації, що вимагають від учнів давати відповіді на питання чи голосувати за допомогою власних гаджетів, переглядаючи презентацію. Прикладами програмних засобів, що дають можливість вчителю створювати такі презентації $\epsilon$, наприклад, Mentimer та Zeetings.

Mentimer (https://www.mentimeter.com) - це онлайн-ресурс для створення інтерактивних презентацій. Він дає можливість утримувати увагу учнів під час демонстрації вчителем презентації (наприклад, під час пояснення вчителем нового навчального матеріалу). Окремі слайди презентації є інтерактивними і, відповідно, учні, що мають гаджети (планшет, смартфон), можуть давати відповіді на поставлені на слайді запитання, і весь клас візуально бачить кількісні показники. 
Zeetings (https://www.zeetings.com/) - ще один онлайн-ресурс, що дає можливість створювати інтерактивні презентації. Учні можуть відповідати на питання, голосувати, залишати коментарі, виконувати тести (синхронно і асинхронно переглядаючи презентацію). А відповідно вчитель може швидко і легко перетворити свою презентацію з PowerPoint в інтерактивну презентацію, додавши відео з YouTube, створивши схему в Canvaforeducation, створивши слайд з опитуванням чи завданням тестового характеру, завантажити PDF-файли чи додати html-коди з інших онлайн-сервісів.

Створюючи презентації до уроків, учителі зазвичай використовують малюнки, схеми та відео. Їх можна знайти в Інтернеті і вставити у презентацію або самостійно створити за допомогою різних ресурсів. Найпростіші малюнки можна створити, користуючись будь-яким графічним редактором, наприклад, Paint.

Для створення яскравих схем можна використати Canvaforeducation (https://www.canva.com/education), Piktochart (https://piktochart.com), Mindmeister (https://www.mindmeister.com/ru), MindMup (https://www. mindmup.com) тощо.

Сучасні учні краще сприймають інформацію, що подана компактно і яскраво. Учитель може прикрасити яскравими і лаконічними схемами, де видно зв'язок між поняттями теми, що вивчається, слайди презентацій до уроків, розмістити їх у своїх соціальних мережах (акаунтах Інстаграм чи Телеграм каналі, що присвячені вивченню математики). Для учнів, що вивчають математику на рівні стандарту, особливо корисним $є$ постійний зоровий контакт зі схемами, створеними вчителем (або учнями). Дає позитивний результат розміщення схем у класній кімнаті на одному й тому самому місці упродовж вивчення теми. За можливістю на одній зі стін можна розміщувати декілька схем з різних тем. Учні також можуть створювати портфоліо 3 таких схем (паперове чи електронне).

Учителі також можуть використовувати готові навчальні відео, знаходячи їх на різних ресурсах, наприклад, на каналах YouTube, що присвячені вивченню математики. Важливо пам'ятати, що відео має бути короткотривалим, українськомовним і безпечним для учнів (давайте покликання на відео учням лише у випадку, коли канал, на якому розміщене відео, не дозволяє розміщення реклами). Наприклад, відео з Всеукраїнської школи онлайн, що були розміщені на каналі $\mathrm{MOH}$ (https:// bit.ly/3y7oWdd). Інколи доцільно використати лише частину відео. У такому випадку вчителю доведеться використати онлайн-редактор відео. 
Навчальні відео учителі можуть створювати самостійно за допомогою спеціального програмного забезпечення, наприклад, CamtasiaStudio (https://www.techsmith.com/video-editor.html), Screencast-o-matic (https:// screencast-o-matic.com/), Canvaforeducation (https://www.canva.com/ education/distance-education).

Так, за допомогою Screencast-o-matic можна здійснити запис з екрана монітора, запис через веб-камеру та комбінувати ці два способи. Тобто вчитель може створити презентацію, а потім записати відео з екрана, паралельно озвучивши його.

Під час створення варто звертати увагу на тривалість навчального відео. Найкраще, якщо для 5-6 класів вона буде становити не більше 4 хв, для 7-9 класів - не більше 6 хв, а для старшокласників - не більше 10 хв. Чим коротше відео, тим легше воно сприймається учнями. Важливо також мінімізувати кількість тексту на екрані. Задля безпеки учнів бажано всі відео завантажувати на власний Google диск або канал YouTube, але із забороною реклами та вказівкою, що цей контент для дітей.

За допомогою PowToon (powtoon.com) чи Explee (explee.com) учитель може створити анімоване відео, що схоже на мультфільм. Але в цьому випадку на виготовлення такого відео піде більше часу.

Будь-яке відео, знайдене в Інтернеті чи зроблене самостійно, можна перетворити на «інтерактивне» за допомогою сервісів EdPuzzle (edpuzzle. com) або H5P (h5p.org). Ці сервіси дають можливість переривати відео завданнями у формі тестів, заповнення пропусків, перетягування ярликів для встановлення відповідності та введення відповіді. Такі «інтерактиви» забезпечують активізацію пізнавальної діяльності учнів і підтримання в них уваги. Бажано, щоб відео переривалось запитаннями чи завданнями кожну хвилину. Саме через цей час спостерігається спад уваги учнів. Запитання до учнів, які переривають відеолекцію, допомагають зробити учневі паузу, усвідомити і проаналізувати почуте. Під час самостійного опрацювання такі завдання, що переривають відеолекцію, стимулюють формування навичок самоконтролю, самооцінки та самокорекції.

Під час дистанційного навчання вчителю доцільно пропонувати учням опрацьовувати різні джерела: підручник, статті, аудіо-, відео-, онлайн-курси тощо. Для опрацювання теоретичного матеріалу вчителі можуть пропонувати учням працювати на онлайн-платформах, що містять вже готовий навчальний контент з математики українською мовою або комплексні онлайн-курси.

- Платформа GIOS (gioschool.com) містить онлайн-курси з математики для 5-9 класів, що розбиті на уроки. До кожного уроку пода- 
но відео, схеми, приклади розв'язаних завдань та серію завдань різної форми та складності. Наприкінці уроку запропоновано ще блок прикладних задач. Учитель може використовувати готові уроки, змінювати ті, що існують, або ж створювати свої за допомогою конструктора уроків.

- Мій клас (miyklas.com.ua/p/algebra). На платформі розміщено уроки для 1-11 класів, що містять теоретичний матеріал у вигляді тексту і практичні завдання до нього.

- Академія Хана (uk.khanacademy.org). Платформа, що містить готові відео з поясненням теоретичного матеріалу і серію запитань до них.

- Курс «Математика. Просто» на платформі EdEra (courses.ed-era.com/ courses/course-v1:EDERA-OSVITORIA+Math101+2019/about) - курс створений для підготовки учнів до 3НО, але може бути використаний і для вивчення окремих тем з математики в 10-11 класах.

- Курс з математики на платформі BeSmart (course.besmart.study/ podgotovka-k-zno-po-matematike) теж створений для підготовки до 3НО, але містить теми, що вивчаються в 10-11 класах.

- Курс підготовки до ЗНО з математики (https://courses.prometheus. org.ua/courses/course-v1:ZNO+MATH101+2017_T1/about).

Формування навичок. Окрім теоретичного матеріалу, важливо, щоб учні мали змогу самостійно опрацювати вже розв'язані типові завдання з теми. Це допоможе їм навчитися розв'язувати такі завдання, а також зменшити кількість запитань, що виникатимуть в учнів під час розв'язування домашніх завдань. Такі завдання можна пропонувати учням розглядати в підручниках або на попередньо створених ресурсах.

Для урізноманітнення форм роботи з учнями та формування в них навичок розв'язування різного виду завдань доцільно вчителю використовувати різні ресурси: готові симуляції, сервіси для створення вікторин, інтерактивні листи, готові вправи, тести чи оболонки, що дають можливість їх створювати. Розглянемо деякі з них.

LearningApps.org (learningapps.org) - це онлайн-платформа, що дає можливість створювати інтерактивні вправи різні за формою. Крім того, цей ресурс має вже готову бібліотеку завдань українською мовою. Наприклад, вправи до теми «Логарифми» можна знайти за покликанням (https://learningapps.org/index.php?category=2\&subcategory=20494\&s=).

Classtime (www.classtime.com) - платформа для створення інтерактивних завдань з українським інтерфейсом. $€$ також можливість використати бібліотеку завдань з певної теми. Учитель може в режимі реального часу відслідковувати результати своїх учнів. 

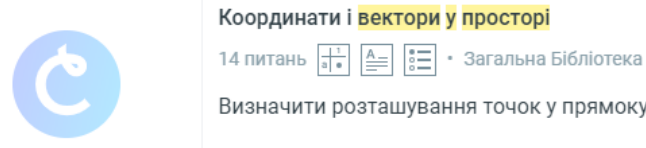

Bсеосвіта (https://vseosvita.ua) - платформа, що надає можливість створювати вчителям власні уроки за допомогою конструктора уроків і містить велику бібліотеку різноманітних завдань у тестовій формі. Наприклад, тест «Паралельні прямі» https://vseosvita.ua/test/7-klas-paralelnistpriamykh-vlastyvosti-ta-oznaky-93085.html.

На урок (https://naurok.com.ua) - платформа, на якій учитель може скористатися тестовою оболонкою для створення власного набору завдань у тестовій формі. Містить велику бібліотеку вже створених іншими вчителями наборів завдань, наприклад, тест «Формули скороченого множення» https://naurok.com.ua/test/povtorennyaformuli-skorochenogo-mnozhennya-totozhni-peretvorennya-racionalnihviraziv-963139.html.

Matific (https://www.matific.com/ua/uk/home/) - платформа з математики для учнів 1-6 класів, що містить симуляції проблемних життєвих ситуацій, для розв'язання яких знадобляться знання з математики. Зручним $€$ конструктор платформи, що допомагає підібрати завдання не лише за рівнем складності, потрібними навичками, а й орієнтовним часом для виконання завдань.

Mathlearningcenter пропонує чудову добірку безкоштовних симуляцій (mathlearningcenter.org/apps) для учнів 1-9 класів.

Onlinetestpad (https://onlinetestpad.com/ua) - оболонка для створення опитувань, тестів, кросвордів, уроків. Містить також бібліотеку готових українських розробок. 
Matematikatests (https://matematikatests.in.ua/) - платформа, що містить готові завдання тестової форми середньої складності саме 3 математики.

Learning.ua (https://learning.ua/matematyka/) - платформа для учнів 1-11 класів, на якій містяться окремі завдання з тем.

Готові завдання також можна знайти на платформі ThatQuiz (https:// www.thatquiz.org/uk/). У ресурсу є українськомовний інтерфейс.

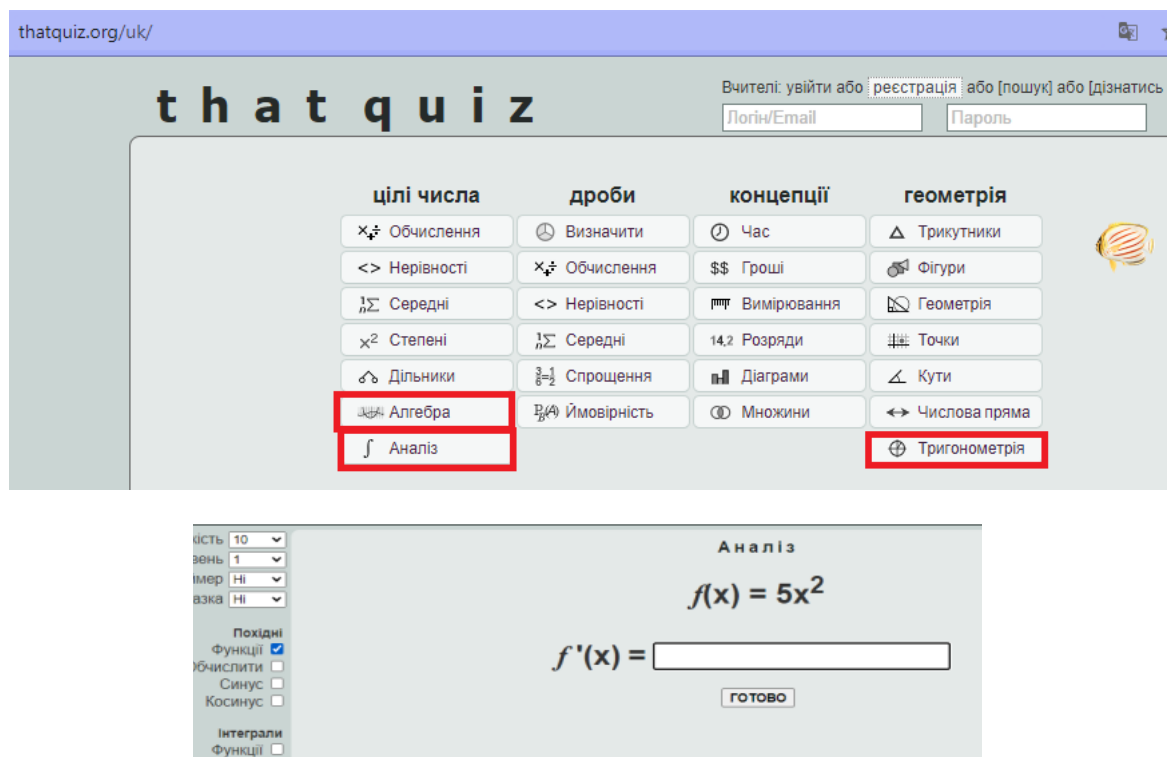

Для продуктивного проведення уроків, що стосуються функцій та їх графіків, існують такі ресурси, як GeometryPad, Desmos та AdvancedGrapher.

DesmosCalculator - потужний онлайн-ресурс (https://www.desmos. com/calculator?lang=uk), що дає можливість легко і швидко побудувати графіки будь-яких функцій. Окрім того, у вчителя, що використовує ресурс TeacherDesmos (https://teacher.desmos.com/?lang=ru), $€$ можливість створювати динамічні моделі для пояснення нового матеріалу чи завдання для дослідницької діяльності учнів, а також використовувати готові розробки (моделі чи вправи) з бібліотеки та створювати власні завдання. Також існує додаток DesmosCalculator, який учитель може завантажити на комп'ютер чи телефон, за умови відсутності у класі Інтернету.

Аналогічний ресурс, який учитель може використовувати без доступу до Інтернету, $€$ AdvancedGrapher та GeometryPad. Наприклад, на уроках в 11 класі під час вивчення тем «Дотична до графіка функції» і «Похідна показникової та логарифмічної функції» учні можуть побудувати графіки 
функцій і дотичну, проведену через дану точку до графіка. Учні будуть мати значення кутового коефіцієнта, тобто значення похідної в цій точці. Також за допомогою цього програмного засобу легко продемонструвати учням геометричні перетворення графіків функції.

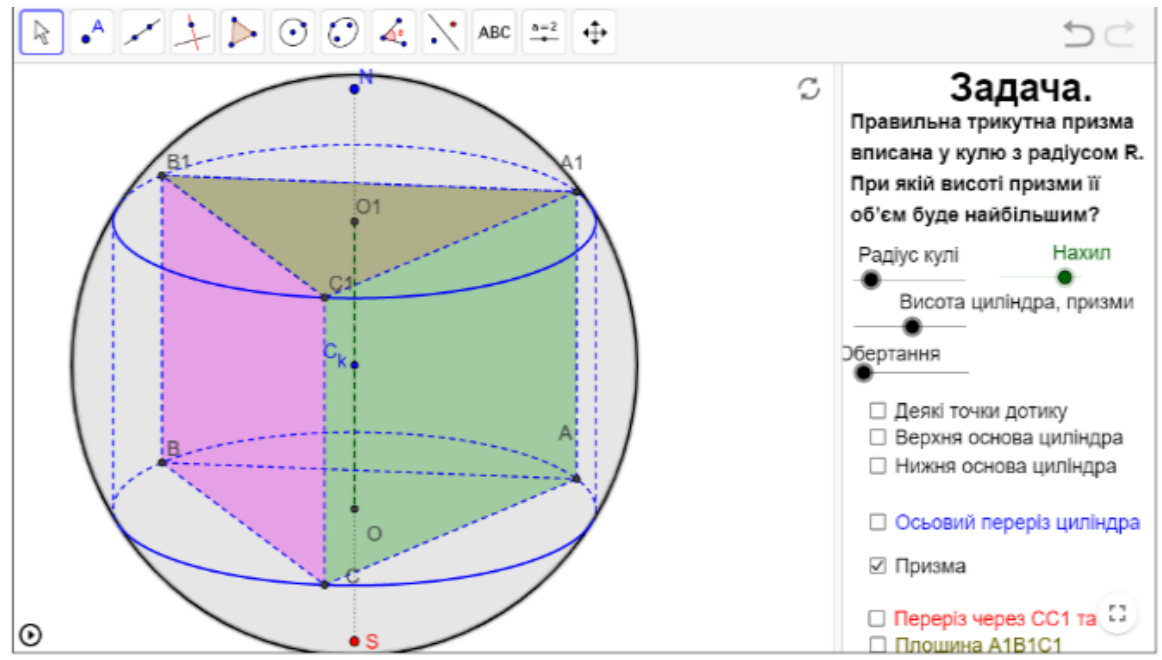

Під час вивчення стереометрії в пригоді стануть такі ресурси, як Shapes 3D та Geogebra. Використовуючи Geogebra (https://www.geogebra.org/t/ math), учитель має можливість не лише створювати власні моделі, а й використовувати бібліотеку вже готових моделей та завдань для учнів. Серед них $\epsilon$ і завдання українською мовою, наприклад, одне з них розміщене за покликанням (https://www.geogebra.org/m/Tm4Uts3b).

За допомогою ресурсу Shapes 3D (shapes.learnteachexplore.com), що має дуже гарний дизайн, наочно можна показати учням розгортки кожної з фігур, розглянути утворення тіл обертання, знайти площу граней, тощо.

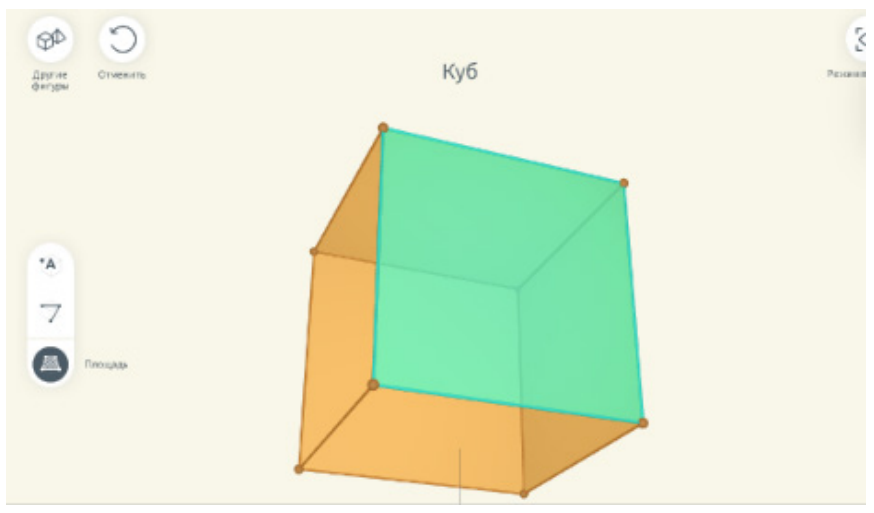


Також для уроків стереометрії стануть у пригоді програмні засоби моделювання фігур для 3D-принтинга. Це - Tinkercad, Thingiverse, Shapeways, AutodeskFusion 360, SketchUp тощо.

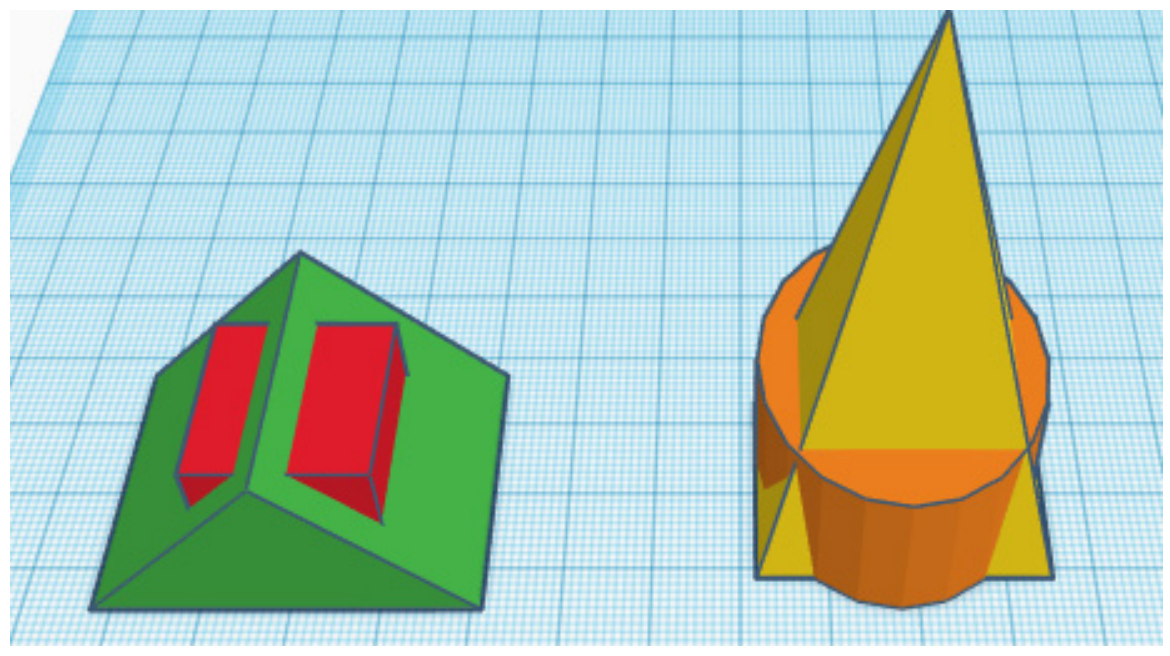

Учитель може використовувати у своїй педагогічній діяльності багато різноманітних сервісів для проведення тестувань та вікторин. Наприклад, Google-форми, Kahoot, Quizizz, Quizalize, Triventy, Plickers, Proprofs, Genially, Learnis. Детальніше про них за покликанням (https://core.ac.uk/ download/pdf/186336525.pdf). Для того, щоб за допомогою них створити цікаву серію завдань для учнів, учитель має заповнити оболонку відповідним математичним контентом. Деякі з них містять готові бібліотеки вже створених наборів завдань.

Сервіси Classtime,Google-форми, Quizizz, Quizalize, Triventy, Proprofs надають статистики вчителям, також їх можна використовувати для контролю знань.

У контексті дистанційного навчання надзвичайно актуальним стає налагодження ефективного та швидкого зворотного зв'язку вчителя з учнями. Для організації навчальної діяльності учнів та комунікації з ними чудово підходить GoogleClassroom. Особливо це зручно для вчителя, що має декілька класів. Для проведення синхронних онлайн-уроків учителі можуть використовувати сервіси Zoom, Skype, GoogleMeet, MicrosoftTeams або Jitsemeet, Discord, MyOwnConference, Liveboard, Miro, BitPaper тощо.

Для проведення синхронних онлайн-уроків для вчителів математики важливо мати онлайн-дошку, яку можуть одночасно використовувати вчитель і учні. Такі дошки є, наприклад, у Zoom або Miro. Також можна скористатися безкоштовними онлайн-дошками Jamboard (jamboard. 
google.com), o-whiteboard (https://o-whiteboard.com) та Mathlearningcenter (apps.mathlearningcenter.org/whiteboard/). Але найзручнішою для вчителя математики є онлайн-дошка Idroo (idroo.com).

На онлайн-уроці в режимі реального часу працювати з підручником стає ще простіше і зручніше, якщо використати PDF-файл підручника та програмний засіб Kami (https://www.kamiapp.com). За допомогою цього ресурсу можна виділяти текст у підручнику, його коментувати, а ще малювати, писати і це все робити синхронно. Таким чином, можна пропонувати учням разом опрацьовувати параграфи підручника, статті чи працювати над матеріалами навчального проєкту.

Чудово, якщо у вчителя є можливість використовувати не лише електронну версію підручника, а й електронний підручник чи електронний навчальний посібник (електронне навчальне видання, що доповнює або частково (повністю) замінює підручник). У такому випадку вчителю доведеться витрачати значно менше часу на організацію дистанційного навчання і підготовку відповідних матеріалів.

Обираючи електронний підручник чи електронний навчальний посібник, учитель має звернути увагу на:

- відповідність навчальній програмі (повністю покривають зміст і вимоги навчальної програми з математики);

- розгалуженість структури;

- забезпечення мотивації навчання (окремі елементи видань привертають увагу учнів і мотивують ї);

- інтерактивність (надається можливість здійснювати зворотний зв'язок між користувачем та системою);

- мультимедійність (використання різних форм представлення інформації (текстової, звукової, графічної, відео, аудіо тощо));

- диреренційована система задач івправ.

Для домашніх завдань учням можна пропонувати роботи, що наперед заготовлені вчителем на інтерактивних робочих листах (дидактичні матеріали з використанням текстів, відео, аудіо, зображень, у тому числі й різноманітних вправ (тести, відповідність, уведення відповіді тощо)). Створювати такі листи можна за допомогою багатьох ресурсів. Наприклад, Wizer.me(Wizer.me), Classkick (Classkick.com) чи Liveworksheets (Liveworksheets.com).

Сучасні учні швидко знаходять потрібну інформацію в Інтернеті, уміло використовують ґаджети та мобільні додатки, легко створюють цікаві презентації, обмінюються дописами в соціальних мережах тощо. Їм не цікаво писати конспекти, але інша форма подачі матеріалу - чудова можливість мозку більш усвідомлено опрацювати матеріал, що по- 
дається, наприклад, у підручнику. Тож, учням можна запропонувати: створити самостійно схему за матеріалом параграфа, діаграму на основі опрацювання статистичної інформації в конкретній статті, онлайн-стіннівку чи відео на задану тематику. У цьому можуть допомогти різні ресурси. Наприклад:

- для створення учнями відео стане у пригоді онлайн-редактор відео Animato (https://animoto.com/business/education). Цей сервіс дає можливість з фото і коротких роликів створити відео, додати підписи і звук (за потреби);

- для створення презентацій учні можуть використати PowerPoint, Google презентації, Sway (https://sway.office.com), Mentimeter (https://www.mentimeter.com), Zeetings (https://www.zeetings.com);

- для створення електронних стіннівок підійдуть Google документи, Padlet (https://padlet.com), Smore (https://www.smore.com);

- для створення зображень, схем чи інфографік учні можуть використати Canvaforeducation (canva.com/education), Piktochart (piktochart.com).

Для того, щоб учні були мотивовані до виконання домашнього завдання, необхідно пропонувати як репродуктивні, так і творчі завдання. Важливо звернути увагу на кількість домашніх завдань. їх краще узгоджувати з учнями, також важливо узгоджувати й аргументувати важливість збільшення кількості домашніх завдань. При цьому доречно привчати учнів планувати свою діяльність, а також нівелювати фактори, що можуть відволікати учня вдома (родичі, тварини, гаджети тощо). За допомогою програмного засобу Miro (miro.com) можна створити дошку з системою Канбан, яка ідеально підходить для планування роботи окремого учня чи групи учнів.

Під час дистанційного навчання перевірка кожної домашньої учнівської роботи займає багато часу. Тож, учителю краще автоматизувати цей процес, використовуючи ресурси, що одразу надають учню зворотній зв'язок щодо правильності виконаних завдань, а вчителю надають статистики по всьому класу і по кожному учню для можливості аналізу результатів і подальшого планування роботи. Наприклад, GIOS, Classtime, Мій клас.

Під час дистанційного навчання, коли контроль кожного учня утруднений, необхідно ретельно продумувати зміст і форми завдань, які вчитель пропонує учням. Бажано, щоб завдання були подані в різній формі, різних рівнів складності і щоб в учнів була можливість вибору завдань. Наприклад, учитель може запропонувати учням розв'язати номер з підручника, що містить 6 однотипних рівнянь, але при цьому кожен учень може вибрати будь-які три рівняння. Звісно, після виконання учень має 
мати змогу звірити отриману ним відповідь чи й все розв'язання. Окрім того, важливо не забувати, що завдання мають бути доступні для учнів.

Як і під час традиційного навчання, на онлайн-уроках мають пропонуватися 4 види завдань: на обчислення, на доведення, на дослідження, на побудову.

Щоб інтенсифікувати роботу над завданнями на доведення, дослідження чи побудову на синхронних уроках можна пропонувати учням складати розв'язання як пазл із запропонованих частин або пропонувати учням знаходити помилки в розв'язанні таких завдань. Також учні можуть коментувати усно доведення ланцюжком (наступного може називати як учень, так і вчитель). Також можна розбирати деякі задачі усно, з акцентом на теореми, що використовуються при доведенні. Наприклад, учні можуть голосувати, за якою ознакою рівні трикутники.

\section{За якою ознакою рівні трикутники?}

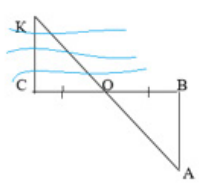

a Mentimeter
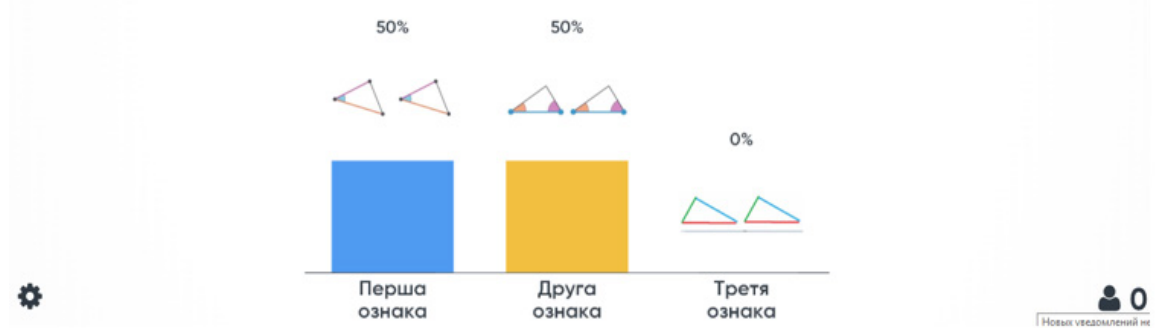

Дуже зручно на синхронних онлайн-уроках розв'язувати з учнями задачі за готовими малюнками. Їх можна брати з чинних підручників або створювати самостійно. Також потрібно не забувати, що і під час дистанційного навчання доцільно пропонувати різноманітні практичні, дослідницькі та проєктні роботи.

Важливо забезпечити взаємодію учнів під час дистанційного навчання. Саме тому, доцільно задіювати інтерактивні методи навчання, у тому числі роботу в парах і в групах під час виконання завдань. Наприклад, можна поділити учнів на групи у Zoom для обговорення способу розв'язання задачі, або ж за допомогою спільних гугл документів запропонувати парам учнів працювати над однією задачею або ж влаштувати змагання учнів за допомогою Kahoot. Також кожному учню можна запропонувати завантажити в padlet свою умову задачі, сформульовану на основі запропонованої учителем схеми, і оцінити умови інших. 
На уроках у режимі реального часу не доцільно робити з учнями те, що вони можуть зробити самостійно, приділяти багато часу запису умови, перевіряти правильність записів і оформлення задачі кожним учнем (краще іноді надати наприкінці виконання завдання слайд для перевірки). Звісно, не доцільно багато часу на синхронному онлайн-уроці відводити на виклад теоретичного матеріалу вчителем, якщо попередньо він міг записати цю частину уроку і вислати ї̈ учням для ознайомлення.

Підсумовуючи усе вище сказане, можемо зробити висновок, що використання та вдале поєднання сучасних програмних засобів навчання може забезпечити всі види навчально-пізнавальної діяльності учнів і професійної діяльності вчителів. Але для опанування цієї технології та адаптації до нових умов потрібен час як вчителям, так і учням.

Для опанування вчителями цієї технології на платформі GIOS за участю співробітників відділу створено безкоштовний курс підвищення кваліфікації для вчителів математики «Змішане навчання математики та особливості його організації в умовах сьогодення» (https://blog.gioschool. com/webinar1_page). Курс складається з 5 відео («Змішане навчання математики: основні моделі, переваги і недоліки», «Особливості вивчення теоретичного матеріалу з математики в умовах змішаного навчання", “Розв'язування завдань з математики в умовах змішаного навчання», «Навчально-пізнавальна діяльність учнів в умовах змішаного навчання", «Основні платформи для організації змішаного навчання») та тесту.

Організації дистанційного навчання сприятимуть мультимедійні підручники, створені співробітниками відділу математичної та інформатичної освіти:

Програмні засоби з математики, розроблені співробітниками відділу математичної та інформатичної освіти Інституту педагогіки НАПН України:

1. Бурда М.І., Вашуленко О.П. Геометрія 7 клас. Мультимедійний підручник. Київ : Розумники, 2011. URL : https://bit.ly/3drWLOy.

2. Бурда М.І., Вашуленко О.П. Геометрія 8 клас. Мультимедійний підручник. Київ : Розумники, 2011. URL : https://bit.ly/2UPrNJJ.

3. Бурда М.І., Вашуленко О.П. Геометрія 9 клас. Мультимедійний підручник. Київ : Розумники, 2011. URL : https://bit.ly/363Whd2.

4. Бурда М.І., Вашуленко О.П. Геометрія 10 клас. Мультимедійний підручник. Київ : Розумники, 2011. URL : https://bit.ly/363Wj4E.

5. Бурда М.І., Вашуленко О.П. Геометрія 11 клас. Мультимедійний підручник. Київ : Розумники, 2011. URL : https://bit.ly/3x01Tky.

Кожен із цих мультимедійних підручників містить мультимедійні уроки з геометрії. Мета уроків, які входять до того чи іншого інтерактивно- 
го курсу геометрії, - дати учням базові знання, допомогти їм засвоїти основні поняття, властивості, формули.

В уроках розкрито теми згідно з навчальною програмою та вміщено: теоретичний матеріал, задачі, словник термінів, малюнки, таблиці, інтерактивні моделі, звуковий супровід тощо. Кожна тема та урок завершується серією тестових завдань, за результатами яких можна зробити висновок про рівень засвоєння навчального матеріалу. Усе це дозволяє учню одночасно споглядати та слухати нову інформацію, за рахунок чого підвищується ефективність засвоєння навчального матеріалу. Окрім того, цей ефект підсилюється за рахунок виконання інтерактивних завдань для самостійної роботи.

Корисною для дистанційного навчання $є$ створена співробітниками відділу математичної та інформатичної освіти бібліотека електронних наочностей з геометрії для 7-9 класів (Бурда М.І., Вашуленко О.П. Геометрія, 7-9 клас. Бібліотека електронних наочностей. Київ : Розумники, 2011. URL : https://bit.ly/3jpXVxy).

Це добірка сучасних мультимедійних інтерактивних навчальних матеріалів з геометрії, спрямованих на ефективне засвоєння понять, формул, теорем і властивостей геометричних фігур. Бібліотека електронних наочностей містить компоненти, що розкривають сутність геометричних понять та закономірностей, а саме: теоретичні відомості, інформацію про відомих математиків, задачі на побудову, малюнки, таблиці, інтерактивні моделі, звуковий супровід тощо. Використання бібліотеки електронних наочностей дозволяє підвищити ефективність навчання, сприяє кращому засвоєнню знань, виробленню вмінь і навичок, формуванню цілісних геометричних образів.

За участі співробітників відділу також створювався контент онлайн-платформи для навчання математики GIOS (https://gioschool. com/), на якій розміщені онлайн-курси з математики для 5-9 класів.

\section{5. ОСОБЛИВОСТІ ДИСТАНЦІЙНОГО НАВЧАННЯ ІНФОРМАТИКИ}

Станом на початок карантину в 2020/21 роках для більшості українських вчителів інформатики організація освітнього процесу з використанням Інтернету не була цілковитим нововведенням. Як свідчать результати опитування, проведеного в групі «Шкільна інформатика від А до Я» (в опитуванні взяли участь учителі 417 шкіл; форму опитування розміщено за адресою https://www.facebook.com/groups/213244579490153/), у 26,3\% українських шкіл швидкість з'єднання з мережею Інтернет становить 100 Мбіт/с і вище, а ще в 42,1\% шкіл ця швидкість становить від 30 
до 100 Мбіт/с. Останній варіант недостатній, наприклад, для одночасного перегляду якісного відео класом учнів, однак цілком придатний для використання систем керування навчальним контентом.

Доступ до Інтернет

412 відповідей

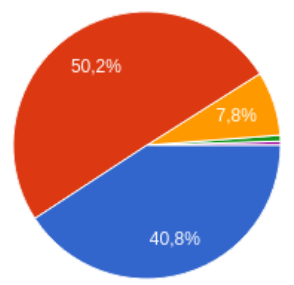

кабель

оптоволокно

бездротовий

мобільний

немає

Швидкість з'єднання мережі Інтернет

411 відповідей

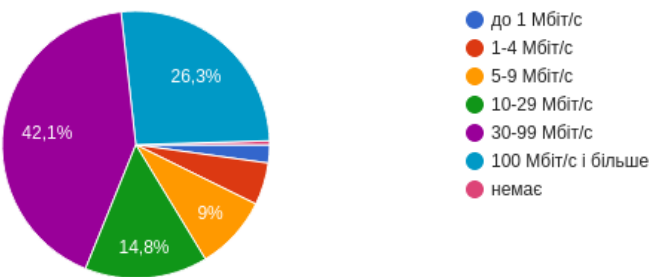

Цей досвід дав змогу значній частині вчителів інформатики підійти до дистанційного навчання у 2020/21 навчальному році підготовленими. В закладах освіти, які мають широкосмугове підключення до Інтернету, для організації освітнього процесу вчителі інформатики використовують не тільки загальноосвітні інтернет-ресурси (як-от LearningApps, Zoom, Google Classroom), а й спеціалізовані онлайнові засоби навчання інформатики. Огляд найбільш популярних в українському освітньому сегменті Інтернету спеціалізованих ресурсів навчання інформатики наведено нижче. їх можна поділити на 3 категорії.

\section{I. Сайти навчальних матеріалів з елементами систем керування} навчальним контентом:

https://dystosvita.gnomio.com/ - авторський сайт вчительки інформатики Сихівської гімназії м. Львова О.В. Пасічник. Містить навчальні матеріали (презентації, інструкції, відеоролики) з усього курсу інфор- 
матики від молодшої до старшої школи. Також на сайті розміщені тести з тем курсу, однак доступ вчителів до результатів тестування $€$ платним.

https://disted.edu.vn.ua/ - сайт Лабораторії інформаційних та комунікаційних технологій Вінницького фізико-математичного ліцею №17 (авт. Ю.Я. Пасіхов та ін.). На сайті надано широкий комплект навчальних матеріалів не лише з інформатики, а й інших дисциплін, однак доступ до повноцінної системи керування навчанням (із тестуваннями, журналом оцінювання тощо) надається лише учням та вчителям ліцею або за спеціальною реєстрацією.

\section{II. Сервіси навчання програмуванню:}

https://www.e-olymp.com/uk/ - створений в Україні міжнародний сервіс навчання олімпіадного програмування. Користувачі ресурсу з авторськими правами можуть створювати задачі та завантажувати тестові розв'язання. На основі цієї інформації учнівські розв'язання задач оцінюватимуться автоматично. Також автори можуть створювати змагання, групуючи задачі і визначаючи час проведення, вимоги до зарахування, рейтингову систему тощо. На ресурсі зібрано понад 9000 задач, проведено більше 14000 змагань. Понад 100 тис. користувачів ресурсу за час його існування надіслали більше 8 млн. розв'язків.

https://code.org/ - найпопулярніший міжнародний ресурс із навчання програмування початківців. Містить сотні задач із блочного програмування, класифікованих за тематикою та складністю. Призначений насамперед для учнів молодшої школи. Ресурс безкоштовний.

https://blockly-games.appspot.com/ - pесурс із навчання блочного програмування, зокрема початків об'єктно-орієнтованого програмування поглибленого рівня, якщо порівнювати із code.org. Містить кілька десятків задач із поясненнями, згрупованих за тематикою та впорядкованих за рівнями складності. Ресурс безкоштовний.

http://scratch.mit.edu - ресурс розробників блочної мови програмування Scratch. Містить онлайновий скретч-редактор. Учні та вчителі можуть розміщувати на ресурсі власні скретч-програми.

https://makecode.microbit.org/ - сервіс, завдяки якому можуть peалізовуватися завдання STEM-освіти. Містить редактор програм для навчального мікроконтролеру micro:bit, робота якого може також імітуватися в браузері.

\section{III. Інтерактивний онлайновий підручник:}

IT-книга (авт. І.О. Завадський та ін.) - на сьогодні фактично єдиний в українському інформатичному просторі повноцінний інтерактивний онлайновий підручник, що відповідає чинним програмам МOH та охоплює весь курс інформатики в основній школі, а також у старшій школі 
на рівні стандарту (базовий і 3 вибіркових модулі). В обмеженому обсязі сервіс можна використовувати безкоштовно; повнофункціональне користування надається за принципом річної передплати.

Основним складником IT-книги є електронний урок - завершений навчальний модуль, спроєктований за дидактичною схемою уроку засвоєння нових знань, що містить етапи актуалізації, опанування нового матеріалу, осмислення нових знань та умінь, закріплення, систематизації та узагальнення (крім тематичних робіт, що організовані за схемою уроку перевірки та коригування знань, умінь і навичок). Теоретичний матеріал в електронному уроці майже ніколи не подається у виключно текстовому вигляді, а супроводжується ілюстративним матеріалом, анімаціями, відео та демонстраціями використання програмних засобів, що вимагають участі глядача, тобто $\epsilon$ інтерактивними.

Невеликі фрагменти теорії перемежовуються міні-завданнями двох типів:

- завдання для закріплення й застосування матеріалу (щойно вивченого або всього уроку);

- «випереджальні» завдання, у яких учень має самостійно знайти відповідь на запитання, яке ще не розглядалося в теорії, але до розуміння якого учня «підводив» попередній матеріал (саме такі завдання найбільше стимулюють мислення).

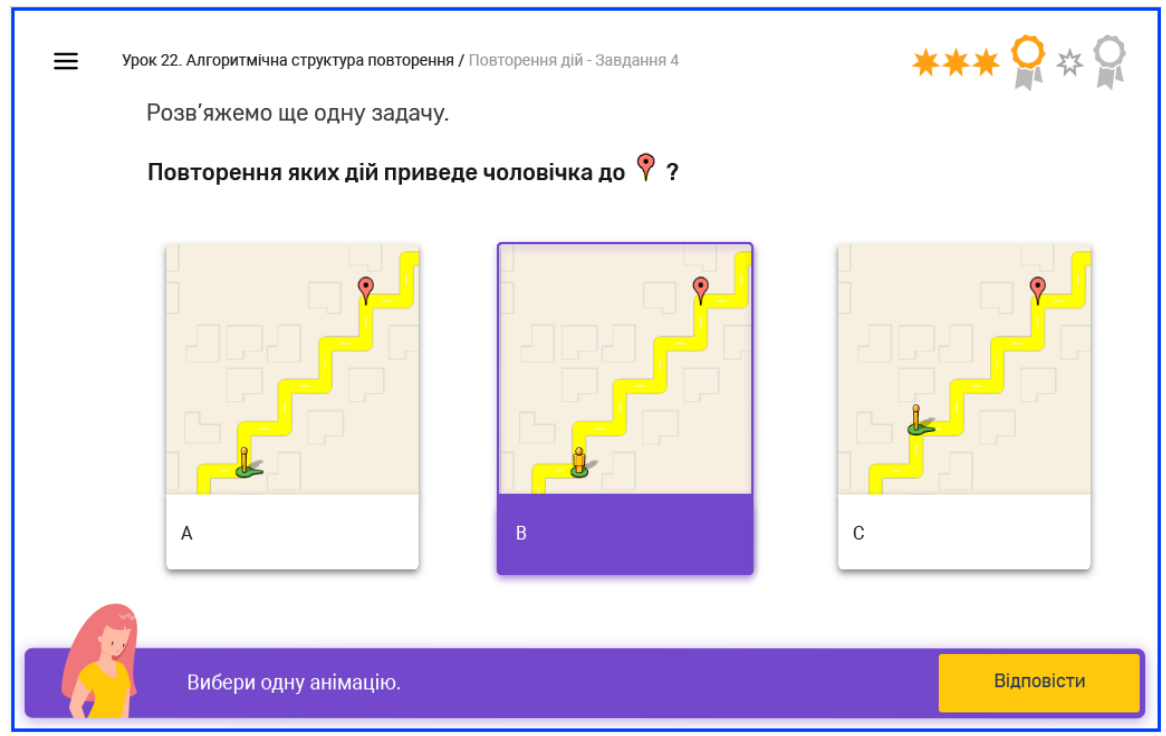


Траєкторія проходження електронного уроку містить елементи нелінійності, адже учням, які неправильно виконують завдання, надаються додаткові пояснення, зміст яких часто залежить від того, яку саме неправильну відповідь вибрав учень. Крім електронних уроків, в IT-книзі надаються конспекти цих уроків у pdf-форматі, окремо для учнів та вчителів, модулі здачі завдань та файли додаткових навчальних матеріалів.

\section{Тема 2. Опрацювання табличних даних. Моделювання}

На виконання кожного уроку дається 6 спроб і виставляється середня оцінка за спробами.

\section{ㄱ. урок 6. Табличний процесор. Загальні поняття \\ Урок6.xIsx - файл-заготовка до уроку 6 \\ Урок 6 - здача завдань \\ Конспект уроку 6 для учнів \\ Конспект уроку 6 для вчителя \\ Сховане від студентів \\ Урок 7. Форматування таблиць \\ Урок 7 - здача завдань \\ Конспект уроку 7 для учнів \\ Конспект уроку 7 для вчителя}

Сховане від студентів

3 технічної точки зору електронні уроки реалізовано у вигляді SCORM-пакетів, які разом із іншими навчальними матеріалами опубліковано в системі керування освітнім процесом Moodle. Робота з IT-книгою вимагає авторизації користувача. $€ 2$ користувацьких ролі: вчителя та учня. Вчитель, крім усіх можливостей, що має учень, має також доступ до журналу успішності, у якому автоматично збираються результати виконання учнями уроків. 


\begin{tabular}{|c|c|c|}
\hline Прізвище $~ / /$ /м'я & 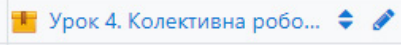 & \# Урок 5. Тематична робот... $\rightleftharpoons$ \\
\hline Гайчук Віталій & $11 @$ & $-Q$ \\
\hline Жовнер Віра & $6 \Theta$ & $5 \oplus$ \\
\hline Кривуля Микола & $6 \Theta$ & $10 \Theta$ \\
\hline Куприненко Даніїл & $8 \Theta$ & $-\oplus$ \\
\hline Надточей Ксенія & $-Q$ & $-\Theta$ \\
\hline Онищенко Анастасія & $-Q$ & $9 \oplus$ \\
\hline Охріменко Назар & $9 \odot$ & $-\oplus$ \\
\hline Павленко Нікіта & $1 \Theta$ & $5 \oplus$ \\
\hline Полозюк Тімур & $7 @$ & $9 \oplus$ \\
\hline
\end{tabular}

Сервіс «IT-книга» може впроваджуватися в освітній процес за двома моделями.

1. Модель «навчання в реальному часі». Електронний урок виконується учнями в класі. Кожен учень рухається траєкторією уроку в індивідуальному темпі, а вчитель виконує роль консультанта, допомагаючи тим учням, у яких виникають складнощі, акцентує увагу учнів на найважливіших завданнях та теоретичних слайдах уроку, підбиває підсумки, формулює домашнє завдання тощо. Більшість уроків IT-книги, якщо виконувати не лише вбудовані в урок завдання, а й вправи в зовнішніх програмах, розраховані на роботу пересічного учня відповідного віку впродовж 1,5-2 уроків. Тому IT-книга найкраще корелює з організацією навчання в тих закладах, де проводяться пари уроків. Проте ніяких проблем не виникає і в разі проведення окремих 45-хвилинних уроків, адже якщо учень не встиг пройти електронний урок до кінця, він може просто закрити вікно браузера, а потім вдома чи наступного уроку в школі зайти в середовище онлайнового підручника під своїм обліковим записом і продовжити навчатися з того місця, де зупинився.

2. Модель «перевернутий клас». За такого підходу електронні уроки доцільно розділяти на два компоненти: 1) теоретичний матеріал та міні-завдання; 2) вправи, що виконуються в зовнішніх програмах. Учень вдома опрацьовує компонент 1 і таким чином проходить необхідну теоретичну підготовку, на базі якої в класі виконує практичні вправи. 
IT-книга усуває всі потенційні складнощі реалізації цієї навчальної моделі, головною з яких в українських реаліях $\epsilon$ ігнорування учнями вимоги самостійної підготовки. Адже завдяки електронному журналу успішності проконтролювати процес самостійної роботи учнів дуже легко: вчителеві доступна інформація не тільки про підсумкову оцінку за урок, а й про оцінку за кожну спробу, час початку та завершення спроби, а також про зміст та час відповіді на кожне завдання.

Інтерактивний онлайновий підручник «ІТ-книга» може використовуватися як одночасно з традиційним паперовим підручником, так і повноцінно замінювати його. Більше того, інтерактивний онлайновий підручник має низку переваг над традиційним, зокрема він:

- стимулює активний, а отже, і більш ефективний спосіб здобування знань;

- полегшує роботу вчителя завдяки автоматизованому оцінюванню знань і робить це оцінювання об'єктивнішим;

- усуває одну з найсерйозніших невідповідностей у сучасній освіті: між традиційним підручником з великими масивами тексту і його потенційними споживачами, тобто поколінням учнів, для якого читання не $є$ основним способом здобування інформації.

У 2020/21 навчальному році інтерактивний онлайновий підручник «IT-книга» для організації дистанційного навчання використовували понад 900 українських вчителів інформатики. При цьому для 380 шкіл «IT-книга» була основним засобом дистанційного навчання інформатики; близько 40000 учнів цих шкіл отримали учнівські акаунти та активно проходили уроки «ІТ-книги» впродовж принаймні одного півріччя.

\section{6. ОСОБЛИВОСТІ ДИСТАНЦІЙНОГО НАВЧАННЯ ПРЕДМЕТІВ ТЕХНОЛОГІЧНОЇ ГАЛУЗІ}

Вивчення предметів технологічної освітньої галузі (трудового навчання, креслення, технологій, профільних предметів і курсів за вибором) має особливості, що зумовлюються їх завданнями, змістом і ресурсним забезпеченням.

1. Одним із основних завдань технологічної освіти є формування способів проєктно-технологічної діяльності, що пов'язані з виконанням практичних робіт, використанням матеріалів, знарядь праці, верстатів та іншого технологічного обладнання.

2. Чинна навчальна програма з трудового навчання для 5-9 класів надає можливість вчителям і учням обирати об'єкти проєктно-технологічної діяльності та застосовувати матеріали і технології з урахуванням умов навчання. 
3. Трудове навчання має формувати життєво необхідні навички, готувати учнів до самообслуговування, ведення господарської діяльності, застосування техніки і технологій у повсякденному житті. Такі навички можуть бути сформовані в домашніх умовах навчання за допомогою педагогічних технологій дистанційного навчання та за участі батьків чи опікунів учнів.

4. Навчальна програма предмета «Технології» для 10-11 класів має модульну структуру, що дозволяє вибирати модулі та змінювати послідовність їх вивчення в залежності від умов навчання.

5. Експериментально апробоване навчально-методичне забезпечення нового змісту предметів за вибором і спецкурсів для профільного навчання технологій, розроблене вченими відділу технологічної освіти Інституту педагогіки НАПН України, надає широкі можливості для вибору навчальних програм і модулів, варіювання змісту навчання з урахуванням місцевих умов, застосування цифрових технологій у процесі очного, дистанційного та змішаного навчання в ліцеях. Однак, такі можливості, як показують проведені дослідження, ще недостатньо використовуються для технологічної освіти учнів в більшості загальноосвітніх шкіл України.

Як і при викладанні всіх загальноосвітніх предметів, учителі трудового навчання і технологій мають проблеми, що пов'язані з недостатнім ресурсним забезпеченням дистанційного навчання. Ці проблеми загострилися під час дистанційної організації самостійного виконання учнями практичних завдань та реалізації учнівських проєктів.

Проблема дистанційного навчання ускладнилася ще й тим, що після введення у 2017 році нових навчальних програм з трудового навчання виникла невідповідність між їх вимогами до результатів навчальної діяльності та змістом виданих раніше підручників «Трудове навчання» для 5-9 класів, що обмежило можливості учнів самостійно опановувати навчальний матеріал за допомогою навчальної книги.

В умовах карантину вчителі трудового навчання були змушені вносити суттєві зміни до календарно-тематичних планів, розроблених на основі чинних програм.

Наразі розроблено та подано для отримання грифу МОН України проєкт модельної навчальної програми «Технології» для учнів 5-6 класів, який має модульну структуру і надає ширші можливості для дистанційного і змішаного навчання та використання різноманітних засобів навчання.

Модельна навчальна програма «Технології». 5-6 класи. (URL : http:// undip.org.ua/upload/files/\%D0\%A2\%D0\%95\%D0\%A5\%D0\%9D\%D0\%9E\%D0\% 9B\%D0\%9E\%D0\%93II._5-6_\%D0\%BA\%D0\%BB\%D0\%B0\%D1\%81\%D0\%B8.pdf). 
В умовах дистанційного навчання деякі вчителі використовують електронні навчальні посібники з трудового навчання, що розроблялися ще на початку 2000 років на базі вже застарілого змісту навчання та програмного забезпечення, що нині не відповідає сучасним вимогам. Відповідно до нового Державного стандарту базової загальної середньої освіти розробляються рукописи підручників з предмета «Технології» для 5 і 6 класів, у яких можливо розміщувати інтерактивні додатки. Однак, видання нових підручників з предмета «Технології» планується тільки з 2022 року.

У процесі трудового навчання учні повинні не тільки ознайомлюватися з принципами роботи механізмів і технологічних машин, а й уміти їх використовувати на практиці. Мати належні умови вдома для виконання практичних робіт і реалізації проєктів без використання навчальних майстерень можуть лише окремі учні. Окрім того, використання ріжучих інструментів, механізмів, верстатів, електричних приладів та інших знарядь вимагає постійного контролю за дотриманням правил безпеки, забезпечити виконання яких без допомоги вчителя чи батьків (опікунів) дуже складно і вимагає застосування нетрадиційних форм організації навчання, відбору його змісту з урахуванням умов дистанційного навчання, розроблення, застосування та поширення інноваційних педагогічних технологій, кращого досвіду роботи вчителів.

На відміну від інших навчальних предметів, з трудового навчання і технологій телевізійні уроки вчителів не демонструвалися. Вчителі та методисти з трудового навчання і технологій розробляли і ділилися своїми відеоуроками в соціальних мережах, використовуючи власні ресурси та можливості.

Для їх підтримки і надання науково-методичного й інформаційного супроводу вченими відділу технологічної освіти Інституту педагогіки НАПН України створено фахові групи в соціальній мережі Facebook: «Texнологічна освіта в Україні» (засновник і адміністратор групи - В. І. Туташинський, URL: https://www.facebook.com/groups/681129769491406) та Всеукраїнський форум «Технологічна освіта» (адміністратор Т. С. Мачача, URL: https://www.facebook.com/groups/Technologicaleducation2019), «Трудове, технології, дизайн, творчість» (URL: https://www.facebook.com/ groups/Technologicaleducation), «Трудове навчання в українській школі» (URL: https://www.facebook.com/groups/597366907085699).

Тут обговорюються найактуальніші проблеми технологічної освіти та у співпраці з методистами інститутів і академій післядипломної педагогічної освіти, творчими вчителями та відомими освітянами поширюється досвід дистанційного та змішаного навчання предметів технологічної освітньої галузі. 
3 метою вирішення проблем дистанційного навчання вчені відділу технологічної освіти Інституту педагогіки НАПН України взяли участь у низці вебінарів та інших науково-методичних заходів:

вебінарі «Методичні аспекти організації та проведення занять із трудового навчання в дистанційному форматі». URL: https://osnova.dacademy.com.ua/course/metodychni-aspekty-organizacziyi-ta-provedennyazanyat-iz-trudovogo-navchannya-v-dystanczijnomu-formati/;

вебінарі "Доповнена реальність на заняттях з кулінарії в дистанційному mрудовому навчанні». URL: https://www.youtube.com/watch?v=PwRLbiOajCo;

вебінарі «Впровадження челенджів як засіб ефективної взаємодії з учнями». URL: https://www.facebook.com/naurok.com.ua/ videos/542839086432030/;

онлайн Міжнародній науково-практичній конферениії. Доповідь на тему: «/нтеграційний потенціал технологічної освітньої галузі нової української школи» (30 хв.). URL: https://bit.ly/3phrQcx.

В умовах карантину також постали проблеми зміни організаційних форм навчання і добору змісту технологічної освіти.

Як показало вивчення практики роботи вчителів трудового навчання і технологій та узагальнення результатів експериментальних досліджень, за завданнями, які надсилали понад 90 \% опитаних учителів, застосовуючи наявні можливості для комунікації, учні могли виконувати тільки частину запланованих проєктів, використовувати матеріали та інструменти, які були в них удома. При цьому вчителі не мали можливості надавати індивідуальну допомогу учням у процесі формування вмінь і навичок. Учні ознайомлювалися з технікою і технологіями переважно тільки за допомогою Інтернет-ресурсів та інших засобів дистанційного навчання.

Понад 80 \% опитаних учителів трудового навчання проводили дистанційне навчання лише за допомогою пересилання учням завдань та оцінювання їх виконання. 3 огляду на проблеми комунікації у віддаленому режимі виконання завдань відбувалося без взаємодії учнів з учителями та однокласниками.

Тільки 7 \% опитаних учителів упроваджували дистанційне навчання у формі онлайн-навчання. При цьому більшість із них намагалися перенести звичні для очних уроків форми і методи на цифрові платформи, що не забезпечувало очікуваної ефективності навчання.

Міжнародний досвід і експериментальні дослідження показують, що під час дистанційного навчання ефективними $€$ такі педагогічні технології навчання, у яких реалізується концепція перевернутого класу (рис. 8, URL: https://learningandteaching-navitas.com/scaffolding-learningmaximising-engagement/tranditional-to-flipped/). 


\section{Концепція перевернутого класу}

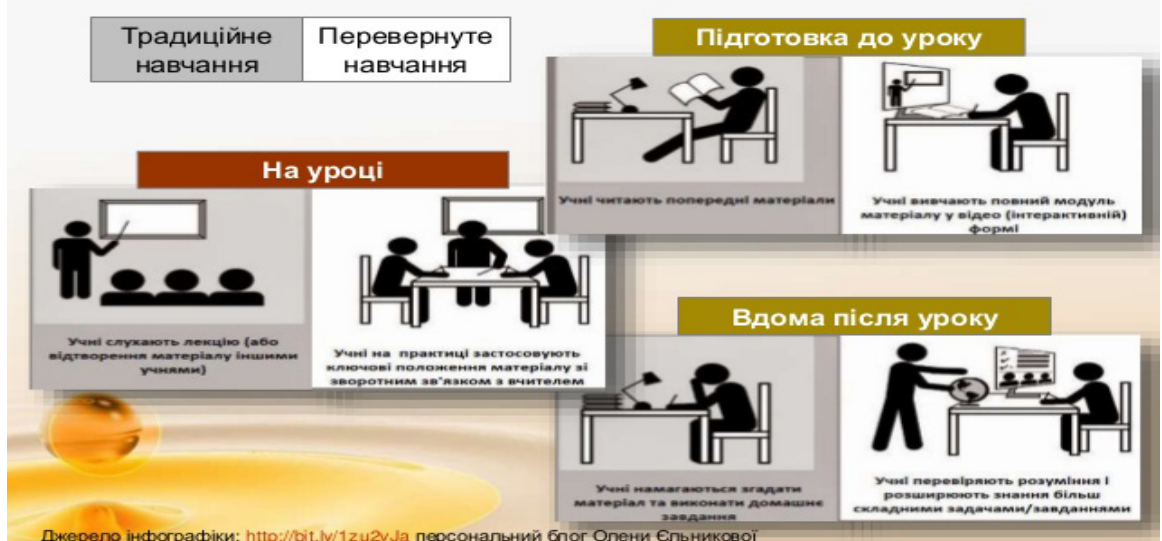

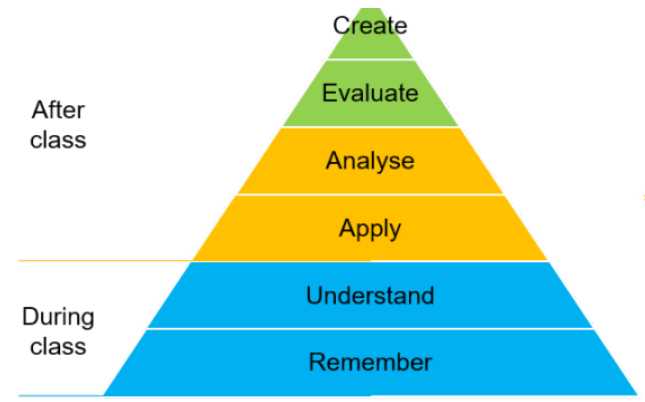

Traditional approach

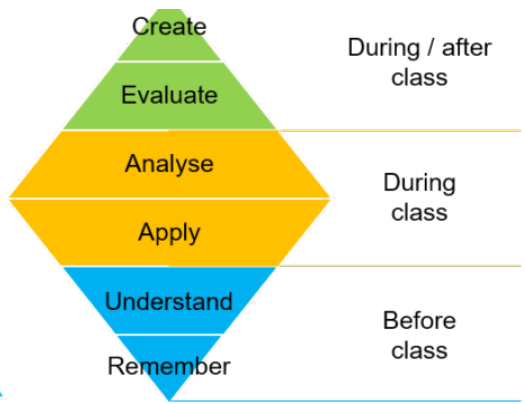

Flipped approach

\section{Рис. 8. Концепція перевернутого класу}

Необхідними складовими для реалізації технології перевернутого класу в умовах дистанційного навчання $€$ :

1. освітня платформа для комунікацій у зв'язку з навчальним контентом;

2. інтерактивні інструкції;

3. моніторинг з метою забезпечення зворотного зв'язку;

4. забезпечення навчальним матеріалом учнів, які не мають доступу до Інтернету.

Під час проведення дистанційного навчання з предметів технологічної освітньої галузі доцільно також застосовувати пошук учнями прототипів майбутніх виробів у мережі Інтернет, використовувати можливості комп'ютерної візуалізації об'єктів техніки і технологій,виконання графічних зображень з допомогою графічних редакторів, 3-D моделювання виро- 
бів, знайомити учнів з можливостями цифрових технологій у виробничій і побутовій діяльності, проводити індивідуальні консультації, заняття в малих групах, надавати відповіді на запитання учнів після самостійного опрацювання ними навчального матеріалу, обговорювати особливості вивчення теми, організовувати розробку та віртуальний захист проєктів, проводити презентації та рекламу виконаних учнями робіт.

У процесі вивчення технологій виробництва в старших класах також можуть застосовуватися відеолекції про сучасні технології, використовуватися вебсайти з підготовленим контентом теми уроку, онлайн-чати тощо.

Ученими спільно з учителями-експериментаторами і методистами під час карантину апробовувалися й поширювалися нові форми й методи дистанційного і змішаного навчання технологій.

На базі Ліцею № 1 Гостомельської селищної ради Бучанського району Київської області в 10 класі технологічного профілю було апробовано зміст і педагогічну технологію змішаного навчання та дистанційного вивчення спецкурсу «Технології сучасного виробництва» (https://bit.ly/3fyRCp6).

За результатами проведеного експерименту видано навчальну програму і підготовлено до видання навчальний посібник.

Результати дослідження підтвердили ефективність запропонованого нового спецкурсу в умовах карантину.

Досвід вивчення трудового навчання, технологій, основ дизайну, профільних предметів та спецкурсів в умовах карантину досліджено вченими Інституту педагогіки, узагальнено й висвітлено в таких наукових публікаціях:

1. Мачача Тетяна. Особливості організації та добору змісту дистанційного проєктно-технологічного навчання в умовах карантину. URL: http://uej.undip.org.ua/Zhurnal/2020/3/Storinky/8.php.

2. Вдовченко В. В. Психологічні аспекти дистанційного навчання в художньо-проєктній освіті: позитивний досвід і проблеми під час занять в домашніх умовах.

3. Вдовченко В. В., Сорочан Н. М. Організація дистанційного навчання в столичній технологічній освіті (на прикладі вивчення «Основ дизайну» та спецкурсу «Художнє проєктування»).

4. Туташинський Василь. Музей як освітній простір технологічної освіти. Музейна педагогіка в науковій освіті : збірник тез доповідей учасників II Всеукраїнської науково-практичної конференції, м. Київ, 26 листопада 2020 р. / за наук. ред. С. О. Довгого. Київ : Національний центр «Мала академія наук України», 2020. С. 216-217.

5. Туташинський В. І., Кірютченкова І. В. Результати вивчення технологій сучасного виробництва у ліцеї. 
6. Тарара А. М., Бондаренко В. В. Форми організації профільного навчання у процесі реалізації змісту спецкурсу інженерно-технічного спрямування.

Мачача Т. С. Авторська педагогічна технологія проєктно-технологічного змішаного навчання як основа формування ключових та галузевої компетентностей.

URL: http://undip.org.ua/upload/iblock/296/druk_anotovani_2020_.pdf.

В умовах застосування сучасних технологій змінюється структура проєктно-технологічної діяльності (рис. 9).

\section{Структура проєктно-технологічної діяльності}

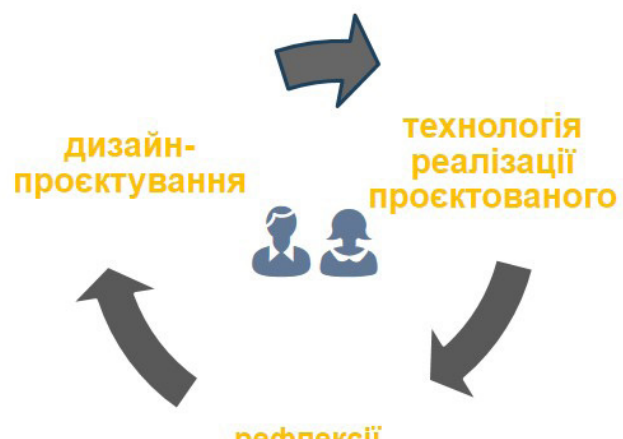

ресрлексії

насчання 6 контексті життя учніб

Науково-практична конференція «Зміст і технології шкільної освіти» Інститут педагогіки НАПН України, 15 січня, 2021

\section{Рис. 9. Структура проєктно-технологічної діяльності}

Дистанційна технологічна освіта висуває як нові вимоги до ефективного та безпечного навчання, так і надає нові можливості, що можуть бути реалізовані за таких умов організації навчального процесу:

- технічного забезпечення навчання онлайн;

- створення якісного контенту для дистанційного навчання (електронних підручників і посібників з інтерактивними додатками, відеофільмів про технології, записів майстер-класів учителів і народних майстрів; бібліотеки електронної наочності тощо);

- організації розроблення колективних проєктів і їх реалізація учнями спільно з батьками (опікунами) вдома;

- залучення учнів до дистанційного проведення природоохоронних акцій з використанням сучасних технологій. 


\section{РОЗДІЛ 5}

\section{ОЦІНЮВАННЯ НАВЧАЛЬНИХ ДОСЯГНЕНЬ ЗДОБУВАЧІВ ЗАГАЛЬНОЇ СЕРЕДНЬОЇ ОСВІТИ В УМОВАХ ДИСТАНЦІЙНОГО НАВЧАННЯ}

\section{1. ОСОБЛИВОСТІ ОЦІНЮВАННЯ РЕЗУЛЬТАТІВ НАВЧАЛЬНОЇ ДІЯЛЬНОСТІ В ДИСТАНЦІЙНІЙ ФОРМІ}

Пандемія COVID-19 прискорила процеси зміни організаційних форматів реалізації освіти, змусила переважну більшість країн світу запровадити різноманітні форми дистанційного (віддаленого) доступу до роботи і навчання. Значну увагу вивченню проблеми забезпечення навчального процесу на всіх освітніх рівнях приділяли різноманітні міжнародні та європейські організації. Зокрема, в аналітичному дослідженні ООН щодо ефективності освітніх політик різних країн світу під впливом пандемії COVID-19 зазначалося, що 94 \% учнів в усьому світі (понад 1,5 млрд. осіб) так чи інакше постраждали від порушення звичайного навчального процесу. Крім того, через закриття шкіл у першу чергу позбавляються доступу до дистанційної освіти та психологічної підтримки діти з обмеженими можливостями, діти-біженці, вимушено переміщені особи [122]. UNDP з'ясувала, що здатність політичних інституцій реагувати на закриття шкіл залежіть від рівня економічного і культурного розвитку країни. Так, упродовж другого кварталу 2020 року в країнах 3 низьким рівнем людського розвитку 86 \% дітей у початковій освіті припинили навчання, у той час, коли в країнах з високим рівнем людського розвитку - лише $20 \%$ [109].

За оцінками Європейської Комісії у половині з 21 європейської країни учні з більш низьким соціально-економічним статусом мали вдвічі меншу ймовірність доступу до Інтернету, в порівнянні з більш забезпеченими однолітками [116]. Навіть за наявної потенційної можливості таких учнів отримати доступ до освітнього контенту, вони не могли повноцінно адаптуватися до дистанційної форми навчання та оцінювання через незадовільні умови їхнього життя, економічний стрес, низький рівень освіти батьків, зокрема рівень сформованості в них цифрової 
компетентності. Таким чином, в усіх країнах світу незалежно від рівня їх економічного розвитку, діти з бідних домогосподарств отримують набагато менше допомоги і підтримки з боку вчителя і батьків для виконання домашніх завдань [51; 127; 129; 130].

Більшість дослідників, як зазначалося вище, відзначають дистанційну як найбільш ефективну і технологічно досконалу форму організації навчальних заходів, у тому числі й контрольно-оцінювальних, незважаючи на виявлені недоліки та проблеми реалізації такого навчання за теперішніх умов у системі загальної середньої освіти. Ключовою вимогою для реалізації дистанційної форми навчання й оцінювання результатів навчальної діяльності учнів $є$ забезпечення доступності (фізичної, фiнансової, інтелектуальної) [44; 45] для здобувачів освіти віртуального освітнього середовища та тієї інформації, яка надається (зосереджується) за допомогою електронних носіїв, що потребує відповідних навичок і компетентностей. Зазначена форма навчання нормативно визначена в Україні як одна з можливих для реалізації у системі загальної середньої, вищої та професійно-технічної освіти [74] за умови наявності технічного приладдя та відповідних навичок учасників, забезпечує можливість повноцінного продовження навчального процесу. У закладах загальної середньої освіти в Україні ця форма організації навчання до періоду запровадження карантину через поширення пандемії COVID-19 мала лише поодинокі приклади застосування. Це стало причиною того, чому, за інформацією голови Державної служби якості освіти Р. Гурака, лише п'ята частина вчителів шкіл проводила уроки онлайн, а майже половина педагогів (41 \%) видавали вправи для самостійного опрацювання без пояснення навчального матеріалу [24].

Оцінювання результатів навчальної діяльності здобувачів загальної середньої освіти, як відомо, $є$ невід'ємною і обов'язковою складовою навчально-вихованого процесу. Оцінювання навчальних результатів виконує низку функцій (розвивальну, виховну, мотивувальну, діагностичну та ін.) та реалізується на різних етапах навчання відповідно до мети оцінювання (поточне, підсумкове). Для його реалізації вчителі використовують відповідні інструменти оцінювання, зміст, рівень складності, а також спосіб використання яких відповідає меті оцінювання.

Найсуттєвіші особливості реалізації оцінювання результатів навчання учнів закладів загальної середньої освіти в дистанційній формі в умовах карантинних обмежень та, відповідно, критерії оцінки ефективності його реалізації проявляються в комбінації різних чинників впливу, а саме: 
- рівня доступу учасників освітнього процесу до Інтернету [44], що потребує наявності комп'ютерної техніки (смартфонів, ноутбуків, iPad та тощо) та надійністю Інтернет-зв'язку;

- сформованістю достатнього рівня цифрової компетентності учнів і вчителів;

- наявністю адаптованого до потреб вчителів електронного освітнього середовища та методичного забезпечення для проведення оцінювання [41].

Аналіз інформаційного поля засвідчив відсутність в Україні ґрунтовних моніторингових і соціологічних досліджень з проблем запровадження у країні під час пандемії COVID-19 дистанційного навчання в закладах загальної середньої освіти. Натомість виявлено численні онлайн-опитування, які проводилися на початку запровадження карантинних обмежень, упродовж квітня-липня 2020 року, різними науковими та громадськими організаціями і які ставили за мету виявити основні недоліки та ставлення різних груп респондентів (директорів, викладачів, учнів і батьків) до реалізації дистанційного навчання в закладах загальної середньої освіти.

Важливим з точки зору аналізу загальної ситуації та формулювання рекомендацій, спрямованих на поліпшення ситуації щодо реалізації оцінювання учнів у дистанційному форматі, $\epsilon$ те, що у проведених онлайн-опитуваннях вибірки респондентів не були випадковими, оскільки всі бажаючі взяти участь у дослідженнях мали вільний доступ до анкет. Це зумовило не лише відмінності в кількісних результатах опитувань, здійснених різними організаціями, щодо залучення здобувачів освіти і вчителів до дистанційного навчання, ступеня актуальності й поширення виявлених проблем його реалізації, а й певні суперечності в оцінках одних і тих самих подій різними учасниками дослідження, що, ймовірно, $€$ наслідком недосконалості самих анкет. Варто також зважати на те, що участь у проведених онлайн-опитуваннях не могли взяти ті учасники освітнього процесу, які з різних обставин позбавлені доступу до потрібних технічних пристроїв (цифрових гаджетів та комп'ютерів) та мережі Інтернет, отже, не висловили своєї точки зору. Відповідно, об'єктивні дані стосовно кількості здобувачів освіти і вчителів, які не залучені до навчального процесу, отже, й до оцінювання, $є$ більшими.

Неможливість дотримання репрезентативності вибірки учасників зменшила достовірність статистичних даних і вірогідність висновків, а також нівелювала певною мірою цінність отриманої інформації для вироблення політичного та управлінського рішення щодо визначення 
найбільш ефективних моделей дистанційного навчання та оцінювання в умовах карантинних обмежень в Україні.

Правовою основою впровадження в період дистанційного навчання нових інструментів і методик оцінювання освітніх результатів здобувачів загальної середньої освіти, у тому числі й проведення державної підсумкової атестації як форми контролю відповідності результатів навчання здобувачів освіти вимогам державних стандартів загальної середньої освіти на відповідному рівні освіти, виступають закони України: «Про освіту» (2017) [79], «Про повну загальну середню освіту» (2020) [80], наказ МОН України «Про затвердження Порядку проведення державної підсумкової атестації» [76].

Упродовж 2020-2021 років МОН України було розроблено інструктивно-методичні матеріали, у яких зазначалося про можливість застосування так званого синхронного та асинхронного режиму оцінювання. Організація оцінювання в асинхронному режимі дає можливість здобувачу освіти виконувати завдання у власному темпі та в зручний для нього час, що зменшує психологічне навантаження і сприяє більш результативній роботі. Синхронний режим передбачає співпрацю учасників освітнього процесу в реальному часі, що, у свою чергу, забезпечує можливість вчителю надавати поради та досить ефективно реалізовувати формувальне оцінювання [62]. Інструктивно-методичні матеріали містили також перелік рекомендованих освітніх платформ і сервісів для реалізації онлайн-навчання, зокрема: Moodle, GoogleClassroom, Zoom, ClassDojo, LearningApps.org, Classtime, Microsoft Teams, GoogleMeet, Skype, Padlet. com тощо [101]. Важливо, що деякі з вказаних освітніх платформ дають можливість запропонувати учням різноманітні вправи для оцінювання результатів навчання в режимі реального часу. Незважаючи на це, масовий перехід системи загальної середньої освіти на дистанційне навчання й оцінювання здобутих учнями знань, навичок і компетентностей став справжнім викликом як для вчителів і адміністрації шкіл, так і для здобувачів освіти та їхніх батьків.

Результати опитувань, що проводилися Київським міжнародним інститутом соціології, свідчать про те, що з кожним роком зростає доступ громадян до Інтернету, проте, приріст кількості користувачів останніми роками помітно сповільнився [14]. Домогосподарства у великих містах майже вдвічі частіше мають доступ до Інтернету, ніж сільські домогосподарства. Виявилося, що понад 17 тисяч населених пунктів з 28 тисяч не мають оптичних мереж взагалі. Близько 65 \% сіл не мають якісного IHтернет-зв'язку, 40 \% шкіл, переважно розташованих у селах або малих містах, не мають доступу до швидкісного Інтернету [87]. На сьогодні за 
інформацією міністра цифрової трансформації України 14 \% населення позбавлені доступу до якісного фіксованого широкополосного Iнтернету через низьку якість (швидкість) або високу вартість послуг з його надання [96].

Виявлено відмінності в доступі до Інтернету членів повних і неповних родин, а також сімей, що мають різну кількість дітей. Так, у звіті Державної служби статистики України зазначається, що в цілому лише 71,1 \% родин з дітьми мають доступ до Інтернету. Ці обмеження посилюються із збільшенням кількості дітей, зокрема у родинах з однією дитиною $73,0 \%$, з двома - 67,3 \%, а з трьома $-64,4 \%$. У неповних родинах (за відсутності одного з батьків) такий доступ мали лише 60,6 \% сімей. Майже половина користувачів Інтернету, які мають дітей, здійснюють цей зв'язок через мобільні телефони (від 42 до 48 \% у залежності від місця проживання, статі та віку), що ускладнює, а іноді й унеможливлює реалізацію оцінювання результатів навчання учнів в синхронному режимі та, відповідно, зменшує ефективність навчання [19].

Незважаючи на те, що під впливом обставин деякі родини були вимушені придбати комп'ютерну техніку для того, щоб мати можливість брати участь у дистанційному навчанні, за результатами дослідження, проведеного упродовж березня-квітня 2020 року Центром інноваційної освіти «Про.Світ», понад 9 \% респондентів визнали відсутність доступу до будь-яких гаджетів, а майже $6 \%$ - відсутність доступу до Інтернету [17]. Зазначене свідчить про неможливість їхньої участі в онлайн-навчанні під час жорсткого карантину, а отже, й позбавляє права рівного доступу до освіти і порушує принцип справедливого оцінювання результатів навчання [46].

Наявність визначального впливу перших двох чинників на реалізацію оцінювання навчальних результатів здобувачів загальної середньої освіти в дистанційному форматі підтверджується результатами практично усіх онлайн-опитувань $[1 ; 17 ; 18 ; 25 ; 65 ; 66 ; 86]$.

Дещо оптимістичнішою виявилася ситуація з оцінкою наявності технічних можливостей учителів початкових класів для здійснення дистанційного навчання в межах реалізації концепції «Нова українська школа» за результатами дослідження, проведеного Інститутом освітньої аналітики. Згідно з цією інформацією, переважна більшість педагогів (93,7 \%) заявили про наявність в них смартфона з доступом до швидкісного IHтернету (72,1 \%), планшета (71,5 \%), персонального комп'ютера (68,6 \%), ноутбука (64,4 \%). Важливо, що суттєвої різниці в рівні забезпечення технічними засобами вчителів залежно від місця розташування закла- 
дів загальної середньої освіти (у сільській чи міській місцевості) виявлено не було [18].

Варто уваги зауваження про те, що у 20,1 \% шкіл дистанційне навчання та оцінювання відповідно було організоване лише з тими вчителями, які мали необхідні навички, технічне забезпечення і доступ до мережі Інтернет. Особливої уваги потребує той факт, що в певній частині шкіл (понад 3 \%), у тому числі й міських, дистанційне навчання не було організоване зовсім [1]. Отже, дистанційним форматом не були охоплені всі предмети навчального плану, що безумовно призводить до погіршення якості освітніх результатів, а також порушує право людини на здобуття освіти.

Варто зазначити, що ситуація з доступом шкіл, учителів і учнів до $\mathrm{lH}_{\text {- }}$ тернету та організацією оцінювання здобутих учнями результатів відрізняється в різних областях і навіть населених пунктах у межах однієї області. Саме через відсутність репрезентативних моніторингових досліджень отримана в ході онлайн-опитувань інформація виявилася суперечливою. Наприклад, згідно з результатами опитування директорів шкіл, найбільша кількість закладів загальної середньої освіти, у яких на початку карантину 2020 року не було розпочато дистанційного навчання, знаходиться у Дніпропетровській, Житомирській та Київській областях. Педагоги також зазначили, що більше, ніж половина вчителів і шкіл у Харківський, Дніпропетровський, Житомирській областях не мали попереднього досвіду використання технологій дистанційного навчання і виявилися неготовими для його запровадження. Водночас, за інформацією тих самих директорів закладів загальної середньої освіти, найбільша кількість шкіл, у яких був попередній досвід використання елементів дистанційного навчання з окремими учнями ще до запровадження карантинних обмежень, теж знаходиться у Дніпропетровській і Харківський областях [1].

За даними Служби освітнього омбудсмена України, достатність і якість технічного обладнання для реалізації онлайн-навчання взагалі та оцінювання зокрема визнали лише 66,5 \% опитаних батьків. Серед проблем із застосуванням наявної в родині комп'ютерної техніки респонденти називали: їі застарілість або непристосованість до реалізації дистанційного навчання, що впливає на погіршення показників здоров'я учнів; відсутність пристрою в індивідуальному використанні учасника освітнього процесу, необхідність ділитися ним з іншими членами родини (54 \% - не мають власного комп'ютера, 66 \% - планшета та $27 \%$ - смартфона) [86]. 
Наступний аспект, що пов'язаний з реалізацією оцінювання результатів навчання учнів, є з'ясування того, які саме освітні платформи, електронні сервіси та соціальні мережі використовували учасники освітнього процесу для встановлення зворотного зв'язку, оскільки кожна з них має свої технічні можливості. Аналіз проведених соціологічних опитувань свідчить про відсутність єдиного підходу і єдиного технічного засобу для проведення оцінювання. Вибір методики оцінювання результатів навчальної діяльності учнів, періодичності проведення контрольних заходів та онлайн-платформи (соціальної мережі або месенджера) визначався кожним учителем на власний розсуд за його особистими вподобаннями й технічними можливостями. Унаслідок цього учні середньої та старшої школи повинні були працювати одночасно в кількох цифрових середовищах, оскільки навчання здійснювали різні вчителі. Учні початкової школи мали можливість в основному використовувати одну платформу або соціальну мережу завдяки тому, що працювали переважно з одним учителем.

Найбільш поширеним у використанні виявився асинхронний режим оцінювання, що реалізовувався через соціальні мережі й сервіси. Учні отримували від вчителів завдання і надсилали фото або скани своїх письмових робіт через Viber та електронну пошту. Лише чверть учителів проводила онлайн-спілкування з учнями для з'ясування рівня опанування ними навчального матеріалу, а 8 \% педагогів взагалі не проводили жодного оцінювання. Причому, за даними деяких інших досліджень, частина вчителів, які не оцінювали успішність учнів, значно більша.

Порівняння даних, наведених різними дослідниками щодо визначення найбільш популярних і затребуваних онлайн-платформ, на основі яких сьогодні організоване дистанційне навчання й оцінювання учнів, виявило неможливість формулювання такого висновку через значні розбіжності у результатах опитувань, які наведено в табл. 5.1, що сталося внаслідок відсутності репрезентативної вибірки учасників та невдалої методології досліджень.

Однак, незважаючи на наявні неточності у вимірюваннях та відмінності в оцінках різних груп респондентів (учителів, директорів, батьків і учнів), незаперечні переваги в частоті використання продемонстрували платформи Googleclassroom, ZOOM, YouTube, електронна пошта та соціальна мережа Viber. Із зазначеного переліку лише платформа GoogleClassroom дає можливість організувати синхронне оцінювання результатів навчання без залучення додаткових технічних засобів і процедур. 
Використання електронних освітніх онлайнплатформ, соціальних мереж і сервісів для організації

навчання учнів у дистанційному форматі

\begin{tabular}{|c|c|c|c|c|c|}
\hline \multirow[t]{2}{*}{$\begin{array}{c}\text { Онлайн-плат- } \\
\text { форми, со- } \\
\text { ціальні мережі } \\
\text { та сервіси }\end{array}$} & \multirow{2}{*}{$\begin{array}{c}\text { Освіт- } \\
\text { ній } \\
\text { омбу- } \\
\text { дсмен, } \\
\% \text { [86] } \\
\\
2020 \\
\text { рік } \\
\end{array}$} & \multirow{2}{*}{$\begin{array}{c}\text { Держав- } \\
\text { на служ- } \\
\text { ба якості } \\
\text { освіти } \\
\text { України, } \\
\% \text { [1] }\end{array}$} & \multirow{2}{*}{$\begin{array}{c}\text { Про.Світ, } \\
\text { праців- } \\
\text { ники } \\
\text { загальної } \\
\text { середньої } \\
\text { освіти, } \\
\% \text { [17] }\end{array}$} & \multicolumn{2}{|c|}{$\begin{array}{c}\text { Інститут іннова- } \\
\text { ційних техно- } \\
\text { логій і засобів } \\
\text { навчання НАПН } \\
\text { України, вчи- } \\
\text { телі, \% [25; 59] }\end{array}$} \\
\hline & & & & 2020 рік & $\begin{array}{c}2021 \\
\text { рік }\end{array}$ \\
\hline Viber & 94,0 & $\begin{array}{r}74,5- \\
92,4\end{array}$ & 92,5 & 88,2 & 83,0 \\
\hline Googleclassroom & 47,2 & $28,4-84,0$ & 45,8 & 45,5 & 15,1 \\
\hline ZOOM & 38,6 & 30,8 & 23,2 & 28,5 & 58,7 \\
\hline YouTube & 35,0 & 35,0 & 63,9 & 72,9 & - \\
\hline Skype & 10,4 & $7,0-14,2$ & - & 37,7 & 14,0 \\
\hline Web-сайт школи & 30,0 & 30,0 & 51,6 & 62,7 & 58,7 \\
\hline «Naurok» & 9,3 & - & 9,3 & 42,7 & - \\
\hline Classdojo & 2,4 & - & 2,4 & 2,4 & 4,0 \\
\hline Classtime & 2,0 & - & 2,0 & 6,2 & - \\
\hline e-mail & 71,5 & $31,3-57,0$ & 71,5 & 71,5 & - \\
\hline Facebook & 12,4 & $6,0-31,0$ & 1,5 & $<3,0$ & - \\
\hline Telegram & 10,0 & - & 1,1 & 20,9 & 13,8 \\
\hline Messenger & 7,1 & - & - & $<3,0$ & - \\
\hline
\end{tabular}

Зазначені сервіси можуть бути використані з різним рівнем ефективності для організації та проведення поточного і формувального оцінювання учнів, але неприйнятні для проведення підсумкового оцінювання, зокрема державної підсумкової атестації, що зумовлює необхідність розробки спеціальних цифрових сервісів і платформ для здійснення підсумкового оцінювання учнів.

Значно більшої уваги потребує зауваження, зроблене батьками, про відсутність оцінювання самостійних і контрольних робіт учнів незалежно від технічного засобу, який використовує вчитель. Так, факт оцінювання учнівських робіт підтвердили лише 63,9 \% батьків, які брали участь в опитуванні, понад 12 \% зазначили про відсутність оцінювання взагалі, 
більше 20 \% визнали наявність окремих часткових випадків поточного оцінювання результатів навчання [86].

Важливою передумовою і чинником впливу на організацію та ефективність оцінювання результатів навчальної діяльності учнів, як зазначалося, є рівень сформованості в учасників освітнього процесу цифрової компетентності та готовності навчатися в дистанційному форматі. За даними Державної служби якості освіти України, у 55,5 \% шкіл дистанційне навчання було проблемою, 47,5 \% учителів, які брали участь в опитуванні, визнали, що раніше не використовували у своїй педагогічній діяльності технології дистанційного навчання, а 35,3 \% вчителів вказали на наявність незначного досвіду. Зазначене певною мірою пояснює причини, через які багатьом учителям було проблематично організувати не лише різнопланове й ефективне оцінювання результатів навчання учнів, а й забезпечити весь навчальний процес у режимі онлайн [85].

Виявлено, що в Україні, як і в інших країнах світу, активність залучення дітей та ефективність реалізації онлайн-оцінювання також значно відрізняються в залежності від віку учня і вчителя, їх цифрової грамотності та наявних у родині технічних і фінансових можливостей; від бажання опановувати нові освітні платформи і технології дистанційного навчання; від ступеня підтримки такого формату надання освітніх послуг батьками [38].

За інформацією Інституту інформаційних технологій і засобів навчання НАПН України, переважна більшість учителів, шкіл, учнів та адміністрації закладів загальної середньої освіти виявили низький рівень готовності (від 1 до 3 за 5-ти бальною шкалою оцінювання) до реалізації дистанційного навчання загалом і проведення онлайн-оцінювання результатів навчальної діяльності здобувачів. Серед питань, які викликали занепокоєння батьків, були ті, що пов'язані з процедурою оцінювання, невизначеністю критеріїв оцінювання, що використовували вчителі.

Значна кількість педагогів скаржилася на відсутність або недосконалість (незручність) інструктивних матеріалів щодо правил використання тих чи інших освітніх платформ і цифрових сервісів, зазначали недостатність занять, консультацій з ознайомлення з цими засобами реалізації дистанційного навчання. Відповідно, така ситуація зумовила більш активне використання вчителями можливостей звичних і знайомих соціальних мереж та інших ресурсів для проведення опитування учнів. 
Для більшості педагогів запровадження дистанційної форми навчання в системі загальної середньої освіти стало викликом, що спонукав до розвитку їхньої професійної компетентності, самовдосконалення, творчого пошуку. Переважна більшість учителів побачила доцільність доповнення в подальшому звичайного режиму навчання дистанційним форматом, можливостями електронного навчання, використанням цифрових освітніх технологій.

Учителі демонстрували усвідомлення необхідності власного саморозвитку і вдосконалення своїх професійних навичок (майже 90 \% респондентів), які пов'язані з реалізацією дистанційного навчання та оцінювання результатів навчання учнів за допомогою онлайн-сервісів. Педагоги розподілили різні джерела інформації щодо курсів підвищення кваліфікації за ступенем популярності та інформативності таким чином: соціальні мережі - 76,3 \%, сайт МOH - 69,4 \%, сайти обласних інститутів післядипломної освіти - 38,1 \%, повідомлення від адміністрації закладів освіти, де працюють учителі - майже 66 \% [59].

Виявлена ситуація свідчить про те, що в ході дистанційного навчання в умовах карантинних обмежень:

- відбулася зміна структури навчального заняття та зміщення акцентів у бік посилення контрольної функції за рахунок усіх інших (розвивальної, мотивуючої тощо);

- збільшилася кількість різноманітних контрольних заходів та зросли обсяги і складність змісту завдань, які учні мали виконувати самостійно і звітувати про результати в письмовий спосіб. Це призвело до перевантаження учнів у порівнянні з періодом навчання в очному режимі, а часто потребувало і значної допомоги з боку батьків для їх виконання та технічного забезпечення зворотного зв'язку з викладачем;

- з поля зору вчителя випав контроль за сформованістю та розвитком практичних вмінь і навичок учнів, а основна увага сконцентрувалася на перевірці теоретичних знань, в основному на репродуктивному рівні інтелектуальної діяльності;

- фактично втратилася можливість для реалізації активних та інтерактивних форм навчальної взаємодії учнів, у результаті якої мали 6 формуватися навички взаємооцінювання і самооцінювання навчальних досягнень.

Варто зауважити, що порівняння результатів опитувань учителів у 2020 і 2021 роках щодо проблем, з якими вони стикаються під час реалізації оцінювання результатів навчальної діяльності учнів в онлайн-режимі, засвідчило їх практичну незмінність. Більш актуальною стала пробле- 
ма реалізації дистанційного навчання й оцінювання в початковій школі, що зумовлено неготовністю і нездатністю учнів молодших класів до самостійної організації власного навчання, а також погіршення якості надання освітніх послуг [25], що, ймовірно, пов'язане із втомою вчителів.

Проведений аналіз набутого впродовж 2020-2021 років досвіду використання в закладах загальної середньої освіти дистанційної форми навчання та оцінювання здобутих учнями результатів виявив низку проблем управлінського, правового, організаційного, технологічного, фінансового та іншого характеру, вирішення яких потребує удосконалення відповідних механізмів управління загальної середньої освіти та розробки ефективних моделей реалізації дистанційного навчання, а також суттєвих змін у системі професійної підготовки педагогічних кадрів.

Виявлена ситуація засвідчила доцільність реалізації наступних кроків, спрямованих на усунення наявних недоліків та врахування набутого досвіду для удосконалення навчального процесу та оцінювання результатів навчання здобувачів загальної середньої освіти в дистанційному форматі:

1. 3 метою створення технічної можливості запровадження єдиної онлайн-платформи для організації дистанційного навчання й оцінювання результатів навчання запровадити систему заходів, спрямованих на максимально повне та якісне покриття Інтернет-зв'язком усієї території України.

2. Обмеження в доступі до Інтернету родин з дітьми посилюються із збільшенням кількості дітей у родині та в неповних родинах. Така ситуація є підставою розробки і впровадження певних соціальних програм підтримки родин з дітьми та надання їм технічних і фінансових можливостей для підвищення рівня доступності для них дистанційної форми навчання.

3. Відсутність на сьогодні репрезентативних і достовірних статистичних даних щодо особливостей і проблем запровадження дистанційної форми навчання в системі загальної середньої освіти в Україні під час карантинних обмежень, пов'язаних із поширенням пандемії, зумовлює необхідність формування / відновлення системи моніторингу якості освіти з розгалуженою територіальною струкмурою.

4. 3 метою зменшення навчального навантаження на учнів та удосконалення системи обліку роботи вчителя під час дистанційного навчання визначити і затвердити нові норми часу на виконання різного роду навчальних і професійних завдань учасниками освітнього прочесу, а також розробити санітарно-гігієнічні вимоги 
щодо організації та часу проведення навчальних занять для учнів різних вікових категорій в онлайн-режимі.

5. Створення єдиної уніфікованої освітньої платформи, принаймні регіонального рівня, сумісної з різними версіями програмного забезпечення персональних комп'ютерів, з можливостями оцінювання в синхронному режимі, з єдиними вимогами користування та розміщенням на ній усіх необхідних навчальних та контрольних матеріалів.

6. 3 огляду на накопичений досвід науково-практичної та педагогічної діяльності закладів післядипломної педагогічної освіти (ОІППО), рівень довіри до них споживачів, звичність і зручність комунікації з ними педагогів виявляється доцільним посилити матеріально-технічну базу для можливості надання ними якісних сучасних освітніх послуг з підвищення рівня цифрової компетентності вчителів закладів загальної середньої освіти, розвитку в них навичок реалізації дистанційного навчання та використання різноманітних онлайн-сервісів і освітніх платформ, розробки валідних тестів та інших інструментів для вимірювання рівня навчальних досягнень учнів.

7. Успішна реалізація в подальшому дистанційного навчання загалом та оцінювання результатів навчальної діяльності здобувачів загальної середньої освіти, зокрема в умовах карантинних обмежень та інших непередбачуваних обставин, потребує попередньої підготовчої роботи, що складається із:

- створення єдиного банку еквівалентних (однакового рівня складності, однотипних) завдань для забезпечення рівності умов, адекватності змісту освіти та справедливості в оцінювання навчальних результатів;

- створення при закладах освіти центрів (серверів) для підключення до єдиної освітньої платформи для забезпечення дистанційного навчання;

- забезпечення дітей, що мають меншу конкурентну спроможність, зокрема із малозабезпечених і багатодітних родин, родин, що проживають у відділених гірських районах, тимчасово переміщених осіб технічним обладнанням (ноутбуками, web-камерами) для забезпечення навчання в дистанційному режимі, навіть і в період не карантинних обмежень;

- запровадження пільгових тарифів для сплати мобільного Інтернет-зв'язку для дітей шкільного віку, особливо на період дистанційного навчання. 


\section{2. РЕАЛІЗАЦІЯ СЕРТИФІКАЦІЙНОГО ОЦІНЮВАННЯ ЗДОБУВАЧІВ ЗАГАЛЬНОЇ СЕРЕДНЬОЇ ОСВІТИ В УМОВАХ ПАНДЕМІї COVID-19}

Пандемія COVID-19 також вплинула на реалізацію сертифікаційного оцінювання здобувачів освіти різних рівнів. Основними тенденціями у 2019/2020 навчальному році стала відміна іспитів на рівні базової середньої освіти та проведення іспитів по завершенню повної загальної середньої освіти, які $є$ вступними іспитами в заклади вищої освіти, у пізніші терміни та з посиленими заходами санітарної безпеки [57]. У деяких країнах ця тенденція продовжилася і в 2020/2021 навчальному році. Зокрема, у 2020 і 2021 рр. в Україні здобувачі початкової, базової та повної загальної середньої освіти (відповідно 4, 9 та 11-го класів) на законодавчому рівні були звільнені від обов'язкового проходження державної підсумкової атестації, зокрема, й у формі зовнішнього незалежного оцінювання [73; 77]. При цьому учні повної загальної середньої освіти мали право за власним бажанням складати державну підсумкову атестацію у формі зовнішнього незалежного оцінювання (3НО).

Натомість 3НО і в 2020, і 2021 рр. залишилось обов'язковою умовою вступу до закладів вищої освіти як єдиний об'єктивний інструмент оцінювання результатів навчання та механізм прозорого конкурсу до закладів вищої освіти. Скасування 3НО, згідно із заявою МОН України, створює значні корупційні ризики під час вступу до закладу вищої освіти і тому $є$ неприпустимим [54].

Проведення 3НО у дистанційному (онлайн) форматі, на думку МOH України, $є$ перспективним, проте нині передчасним, оскільки відсутні відповідні технічні умови для його проведення. Адже така технологія потребує запровадження низки заходів, пов'язаних із забезпеченням неупередженості й об'єктивності результатів 3НО, ідентифікацією учасників та протидією списуванню й іншим проявам недоброчесності [83]. Саме тому в 2020 р. іспити 3 НО в Україні проводилися в пізніші терміни - з 25 червня по 17 липня [52]. У 2021 р. ЗНО проводилося у звичний термін - з 21 травня по 15 червня [58].

Не лишилося осторонь змін також і пробне 3НО. У 2020 р. через карантинні обмеження воно було проведено в дистанційному форматі. Здобувачі освіти заходили у свій кабінет учасника пробного 3НО, розміщеного на сайті відповідного регіонального центру оцінювання якості освіти, завантажували тестовий зошит і бланк відповідей з обраного предмета (обраних предметів), виконували завдання тестового зошита та вносили результати в “Сервіс визначення результатів», а потім через певний час отримували свої результати за тестування [57]. 
У 2021 р. пробне ЗНО відбувалося у звичному (очному) режимі, але кожний учасник (учасниця) міг вибрати і скласти лише один предмет [22]. Також учасник / учасниця могли додатково завантажити тестові зошити з усіх навчальних предметів із переліку предметів 3НО-2021 та пройти тестування вдома.

В інших країнах процедури сертифікаційного оцінювання випускників закладів загальної середньої освіти у 2020 і 2021 роках також зазнали змін під впливом карантинних обмежень, зумовлених поширенням пандемії COVID-19. Так, у Республіці Казахстан у 2020 р., як і в Україні, шкільні випускні іспити (аналог української державної підсумкової атестації) були відмінені для здобувачів освіти II та III ступенів (9-го і 11 (12-го) класів). Підсумкова атестація здійснювалася на основі річних оцінок, а державні випускні іспити - Єдине національне тестування (далі $-\epsilon H T)$, яке зараховується як вступні іспити в заклади вищої освіти були перенесені на пізніший термін відповідно до епідеміологічної ситуації [20]. Також у 2020 р. було змінено формат пробного тестування $\in H T$, яке проводилося в режимі онлайн. Тобто, здобувачі освіти відразу після тестування отримували свої результати за тест і мали можливість бачити правильність відповіді на кожне завдання тесту.

У 2021 р. в Республіці Казахстан не планують відміняти підсумкову атестацію випускників 9-х і 11 (12)-х класів. Вона пройде у звичному режимі (три іспити для випускників 9-го класу та чотири - для 11 (12)-го класу) та у звичний термін (у кінці травня - на початку червня). Водночас, суттєві зміни передбачено в організації та проведенні ЄНТ: воно має бути реалізоване у так званому електронному (не онлайн) форматі упродовж трьох місяців (з квітня по червень) [95]. Така процедура не передбачає графіка складання іспитів, що дає можливість здобувачу освіти скласти ЄНТ в спеціалізованих центрах тестування за допомогою комп'ютера у будь-який зручний для нього час упродовж трьох визначених місяців. Зв'язок центрів тестування з регіональними центрами здійснюватиметься по закритому VPN-каналу, у який неможливо «врізатися» ззовні, а на комп'ютерах будуть відсутні роз' $є-$ ми для флеш-карт та USB. Ідентифікацію тестовані проходитимуть за допомогою технології Face-ID і над кожним тестованим розташовуватиметься камера спостереження. Тобто, ЄНТ буде проводитися за принципом «один тестований - один комп'ютер - одна камера». При цьому здобувач освіти матиме дві безкоштовні спроби скласти тестування.

У Вірменії, Латвії, Литві та Ірландії у 2020 р. були відмінені шкільні випускні іспити (державне тестування) по завершенню основної (базової) середньої освіти та перенесено терміни проведення випускних (централізованих) іспитів для випускників повної загальної середньої освіти, які зараховуються як іспити для вступу до закладів вищої освіти. У 2021 р. 
у Вірменії та Латвії також відмінено проведення випускних іспитів (державного тестування) по завершенню основної (базової) середньої освіти. Проте здобувачі освіти 9-го класу шкіл національних меншин Латвії у 2020 і 2021 рр. за власним бажанням могли скласти централізований іспит з латвійської мови [57; 115].

Також у2020 і 2021 рр. у цих країнах було зменшено кількість іспитів для випускників повної загальної середньої освіти. У Вірменії у 2020 р. для вступу до закладів вищої освіти випускники 12-х класів складали лише один іспит, а не два чи три як у 2019 р. [23], у в 2021 р. складатимуть не більше двох іспитів [67]. Наприклад, для вступу на спеціальність економіста випускники мають скласти обов'язковий іспит з математики та іспит або з вірменської мови і літератури, або іноземної мови на вибір учня.

У Латвії у 2020 і 2021 р. випускники повної загальної середньої освіти (12-го класу) складали лише три обов'язкових предмети (латвійська мова, математика та іноземна мова) та мали можливість скласти ще один іспит (четвертий) з предмета на вибір (за їхнім бажанням). У 2019 р. один або кілька іспитів на вибір були обов'язковими (четвертим, п'ятим тощо) іспитами для випускників 12-го класу.

Особливістю централізованих іспитів для випускників повної загальної середньої освіти 2020 і 2021 рр. у Латвії було зменшення до 3 год тривалості іспитів та проведення їх без перерв (щоб не було потреби змінювати маски педагогам і здобувачам освіти), а також зменшення кількості завдань у тесті у зв'язку зі зміною часу проведення іспитів (але не за рахунок зниження рівня складності тестів) [118].

Ще однією особливістю шкільної системи Латвії, яка є особливо актуальною в умовах переходу закладів загальної середньої освіти на змішане й дистанційне навчання, $є$ проведення діагностичних робіт для випускників 3-х, 6-х та 11-х класів. Метою дистанційних робіт стало не лише визначення рівня освітніх досягнень здобувачів освіти, а й оцінювання досягнень та недоліків дистанційного навчання упродовж 2020/2021 навчального року [112].

Передбачено, що за допомогою діагностичних робіт: 1) визначається рівень освітніх досягнень здобувача освіти відповідно до вимог навчального предмета на кінець 3-го, 6-го і 11-го класів; 2) виявляються труднощі, з якими стикається учень під час вивчення предмета (тобто, знання і вміння, які він не засвоїв або погано засвоїв); 3) визначаються корекційні заходи щодо усунення цих труднощів до кінця поточного навчального року (діагностичні роботи проводяться в березні або квітні). 
При цьому діагностична робота оцінюється у відсотках й оцінка за неї не впливає на семестрову та річну оцінки.

У 2021 р. у зв'язку з відміною іспитів для випускників 9-го класу уряд Латвії прийняв рішення про заміну їх діагностичними роботами [115]. 3окрема, випускники 9-го класу у квітні складали обов'язкові діагностичні роботи з латвійської мови та математики. Окрім того, заклад загальної середньої освіти отримав право організувати додаткову діагностичну роботу: або з іноземної мови (англійської, німецької, французької чи російської - на вибір здобувача), або з історії Латвії (рідною мовою здобувача в закладі загальної середньої освіти національних меншин), або з природничих наук (фізика, хімія, біологія, географія), що допоможе здобувачу освіти вибрати напрям навчання в середній освіті. (Випускники 3-го класу складають три діагностичні роботи: з мови навчання, математики та латвійської мови; випускники 6-го класу - чотири: з мови навчання, математики, латвійської мови та природознавства [ 112]).

У Польщі у 2020 р. було перенесено дати проведення іспитів 8-го класу (польська мова, математика та сучасна іноземна мова), які складають здобувачі освіти по завершенню базової середньої (початкової) школи, та іспитів на атестат зрілості (matura), що складаються випускниками закладів повної загальної середньої освіти. Як і в інших країнах світу, іспити 8-го класу та іспити на атестат зрілості відбулися з певним запізненням у порівнянні з минулими роками. У 2021 р. іспити відбудуться у звичний період - у травні.

У Республіці Молдова та Великій Британії у 2020 р. були відмінені випускні іспити для здобувачів базової та повної загальної середньої освіти (гімназії та ліцею в Республіці Молдова та на атестати про завершення середньої школи (General Certificate of Secondary Education (GCSE)) і повної середньої освіти A-Level у Великій Британії). При цьому в Республіці Молдова, де вступ до закладів вищої освіти відбувається на основі диплома про закінчення ліцею, оцінки з екзаменаційних предметів, які виставляли здобувачам освіти в атестати, були середніми оцінками здобувачів освіти з того чи іншого екзаменаційного предмета за 7-9 (для випускників гімназії) та 10-12 класи (для випускників ліцею). Оцінка округлювалася до цілого бала [119].

У 2021 р. в Республіці Молдова планується проведення випускних іспитів для здобувачів базової та повної загальної середньої освіти, однак, ця ідея зазнала доволі потужного спротиву з боку здобувачів освіти [121]. Вони аргументують свою думку тим, що періоди дистанційного навчання негативно вплинули на рівень їхніх освітніх досягнень. 
У Великій Британії у 2021 р., як і в 2020 р., через епідеміологічну ситуацію в країні були відмінені іспити на GCSE та A-Level. У 2020 році оцінки за іспити були розраховані Центром управління кваліфікаціями та іспитами (The Office of Qualifications and Examinations Regulation (Ofqual)) на основі оцінок учителів та прогнозованих оцінок за іспит [57]. При цьому враховувалися такі показники навчально-пізнавальних досягнень кожного учня, як прогнозована вчителем оцінка (оцінка, яку, на думку педагога, отримав би здобувач освіти на іспиті), результати пробних іспитів, накопичена оцінка за уроки і домашні завдання, будь-які неекзаменаційні оцінки, загальний прогрес упродовж курсу, рейтинг здобувача освіти в закладі загальної середньої освіти за успішністю. При цьому вчителі надсилали Центру управління кваліфікаціями та іспитами (Ofqual) оцінки учнів та їхні рейтинги в класі з усіх предметів. Також Центр Ofqual під час виставлення здобувачу освіти оцінки враховував рейтинг закладу освіти серед інших закладів, середні результати учня в минулі роки та розподіл отриманих оцінок на національному рівні. Здобувачі освіти, які були не згодні з оцінками за іспити, мали змогу подати апеляцію та здати іспити восени 2020 р. або влітку 2021 р. На відміну від минулого року, у 2021 році оцінки за іспити виставляли самі вчителі [108], ураховуючи успішність здобувача освіти упродовж року, результати пробних іспитів тощо, а не спеціальний алгоритм.

Досить цікавим у контексті розроблення альтернативних систем оцінювання є досвід Гонконгу. У цій країні ані у 2020, ані у 2021 р. не було скасовано проведення іспитів на здобуття сертифіката про середню освіту (Hong Kong's Diploma of Secondary Education (HKDSE)) для випускників старших класів. У 2020 р. терміни проведення цих іспитів було перенесено на місяць пізніше та розпочато створення альтернативної системи оцінювання [99]. 3 цією метою заклади загальної середньої освіти надсилають навчальні бали випускників до Центру іспитів та оцінювання в Гонконгу, де ці бали порівнюються з результатами HKDSE для розроблення прогнозної моделі.

Отже, пандемія COVID-19 вплинула як на технології, так і на методологію проведення ДПА і ЗНО в Україні та інших країнах. Основними тенденціями 2020 р. стала відміна іспитів на рівні базової середньої освіти та проведення іспитів по завершенню повної загальної середньої освіти, які $€$ вступними іспитами в заклади вищої освіти, у пізніші терміни. У 2021 р. сформувалися дві тенденції: 1) використання минулорічної (2020р.) моделі проведення ДПА і ЗНО. Наприклад, в Україні у 2020 і 2021 рр. було відмінено проведення ДПА для випускників 9-х і 11-х класів, але не відмінено проведення 3НО. У Великій Британії вже 
другий рік поспіль не проводяться іспити на GCSE та A-Level; 2) повернення до минулорічних («допандемічних») моделей проведення ДПА і ЗНО. Наприклад, у 2021 р. планується проведення випускних іспитів по завершенню основної (базової) та повної загальної середньої освіти у Республіці Казахстан і Республіці Молдова, однак остаточне рішення буде залежати від епідеміологічної ситуації в цих країнах.

Перспективним з точки зору удосконалення української моделі сертифікаційного оцінювання здобувачів загальної середньої освіти, на наш погляд, є досвід інших країн, зокрема:

- Республіки Казахстан, де запроваджено проведення Єдиного національного тестування (аналог українського 3НО) в електронному форматі (не онлайн). 3 огляду на технічні труднощі та необхідність підготовки учасників освітнього процесу до такої форми підсумкового оцінювання доцільним видається запровадження такої процедури складання іспитів (3НО) з окремих навчальних предметів (з обов'язкових або, навпаки, з предметів на вибір, з огляду на значно меншу кількість учасників);

- Латвії, де запроваджено виконання так званих діагностичних робіт наприкінці навчального року з метою виявлення труднощів у здобувачів освіти під час вивчення предмета та усунення цих труднощів до завершення навчального року. Особливо актуальними проведення таких робіт $\epsilon$ під час переведення закладів ЗСО на змішане і дистанційне навчання. Вважаємо, що діагностичні роботи в закладах ЗСО України треба провести вже на початку 2021/2022 навчального року (адже провести їх наприкінці 2020/2021 навчального року немає можливості) і, у випадку переходу 33 СО і у 2021/2022 навчального року на дистанційне і змішане навчання, не пізніше березня 2022 р. Також уважаємо, що такі роботи мають проводитися в усіх класах, починаючи з 2 або 3 класу.

\section{3. МОЖЛИВОСТІ ТА ПРОБЛЕМИ РЕАЛІЗАЦІї ПІДСУМКОВОГО ОЦІНЮВАННЯ НАВЧАЛЬНИХ РЕЗУЛЬТАТІВ У ДИСТАНЦІЙНІЙ ФОРМІ}

Предметом дискусії освітніх експертів, громадськості, науковців стало проведення в Україні підсумкового оцінювання, зокрема державної підсумкової атестації здобувачів базової освіти (випускників 9-х класів) за умов дистанційної форми навчання під час карантинних обмежень [39; 49]. Цей вид оцінювання досягнутих освітніх результатів здобувачів освіти ґрунтується на принципах забезпечення конституційного права 
громадян щодо рівного доступу всіх учнів до якісної освіти [48], об'єктивності контролю та оцінювання результатів, гуманістичної спрямованості, обов'язковості складання.

Актуальність і гострота зазначеної проблеми зумовлена, з одного боку, необхідністю реалізації принципу справедливості в оцінюванні результатів навчання в контексті забезпечення дотримання конституційних прав дітей на здобуття загальної середньої освіти як обов'язкової незалежно від соціального і майнового стану, світоглядних переконань, стану здоров'я, місця проживання, здібностей та впливу різних чинників соціального, правового, економічного, культурного та іншого характеру тощо [46], а з іншого, - створення для всіх учасників випробувань рівних умов та одночасно комфортного і безпечного, з урахуванням загроз інфікування, освітнього середовища.

Запровадження нової моделі проведення ДПА випускників повної загальної середньої освіти взагалі та базової середньої освіти зокрема супроводжується визначенням ії концептуальної основи [42], основного призначення [43], функцій [50] та мети проведення [36], ставлення до неї педагогів та здобувачів освіти, а також оцінкою можливих переваг і очікуваних недоліків від ії зміни [47], що зумовлено проблемами фінансово-економічного, технічного характеру, так і проблемами, пов'язаними з питаннями кадрового (професійні та навчальні компетентності учасників освітнього процесу, психологічна готовність тощо) [40].

Серед розмаїття можливих форм проведення підсумкових випробувань випускників базового рівня середньої освіти в умовах запровадження карантинних обмежень найбільш доречною виявляється реалізація організаційної моделі складання державної підсумкової атестації в дистанційному форматі. Дана модель може бути використана як за будь-яких карантинних обмежень, так і за їх відсутності в тому числі. Для ії реалізації необхідні наявність в учня комп'ютера (ноутбука) з мікрофоном і відеокамерою, використання можливостей цифрових технологій та встановлення віддаленого доступу до завдань державної підсумкової атестації в реальному часі. За наявності зазначеного обладнання учень у визначений час повинен підключитися до певного обраного сервісу 3 персональним ключем, забезпечити можливість відеофіксації його робочого місця. Після цього учень отримує на персональну сторінку сервісу завдання (наприклад, з математики) і виконує його на листках паперу із зазначенням свого прізвища та інших персональних даних, потрібних для ідентифікації особи. По завершенню часу іспиту, учень демонструє роботу на камеру, фотографує (або сканує в разі наявності можливо- 
стей) свою роботу і надсилає файли на вказану адресу для перевірки. Перевіряючі повинні мати можливість порівняти надіслану роботу з тією, що зафіксована на камеру, після - оцінюють їі. У разі складання диктанту замість слайду із завданням учень прослуховує аудіозапис з текстом диктанту і пише його. Якщо технічні можливості середовища або програмного забезпечення для проведення державної підсумкової атестації в дистанційному форматі дозволять, то виконання учнем екзаменаційних завдань (наприклад, тестів) може бути реалізоване в електронному форматі у режимі онлайн.

Результати SWOT-аналізу моделі запровадження державної підсумкової атестації випускників гімназій у дистанційному форматі наведено в табл. 5.2.

Таблиця 5.2

Матриця SWOT-аналізу дистанційної моделі проведення державної підсумкової атестації здобувачів базової середньої освіти [41]

\begin{tabular}{|c|c|}
\hline Сильні риси - S & Слабкі риси - W \\
\hline $\begin{array}{l}\text { Універсальність, } \\
\text { використання за } \\
\text { будь-яких карантинних } \\
\text { обмеженнях, в умовах } \\
\text { звичайного освітнього } \\
\text { процесу. } \\
\text { Знаходження учнів у } \\
\text { безпечних домашніх } \\
\text { умовах. } \\
\text { Використання техноло- } \\
\text { гї̈ ЗНО. } \\
\text { Можливість формулю- } \\
\text { вання індивідуальних } \\
\text { варіантів завдань } \\
\text { шляхом їх випадкової } \\
\text { вибірки з великої бази } \\
\text { завдань. } \\
\text { Швидка передача уч- } \\
\text { нем атестаційних робіт } \\
\text { та наявність зворотно- } \\
\text { го зв'язку. }\end{array}$ & $\begin{array}{l}\text { Недостатній рівень сформованості в учнів } \\
\text { відповідних навичок роботи з цифровими } \\
\text { гаджетами та іншим приладдям. } \\
\text { Неможливість дотримання всіх умов для } \\
\text { забезпечення контролю за самостійним і } \\
\text { своєчасним виконанням учнем випускової } \\
\text { роботи в дистанційному режимі. } \\
\text { Надмірне психологічне навантаження на } \\
\text { учня через підвищену відповідальність за } \\
\text { результат складання і побоювання можливих } \\
\text { технічних збоїв під час виконання атестацій- } \\
\text { них завдань. } \\
\text { Перекладання частки витрат на родини } \\
\text { (батьків та осіб, що їх заміняють) щодо за- } \\
\text { безпечення учня технічними засобами для } \\
\text { складання державної підсумкової атестації в } \\
\text { дистанційному форматі, а отже, і порушення } \\
\text { принципу безоплатності здобуття загальної } \\
\text { середньої освіти. } \\
\text { Правова неврегульованість випадків по- } \\
\text { вторного складання державної підсумкової } \\
\text { атестації через технічні проблеми при спробі } \\
\text { реалізувати дистанційну модель складання } \\
\text { іспитів. }\end{array}$ \\
\hline
\end{tabular}




\begin{tabular}{|c|c|}
\hline Потенційні можливості - O & и реалізації) - T \\
\hline $\begin{array}{l}\text { Забезпечення можливості } \\
\text { дотримання санітарно-гігієніч- } \\
\text { них вимог та карантину для } \\
\text { запобігання поширення інфек- } \\
\text { ції та загострення епідеміоло- } \\
\text { гічної ситуації в регіоні. } \\
\text { Повноцінне завершення на- } \\
\text { вчального року та планування } \\
\text { структури класів профільної } \\
\text { школи за результатами дер- } \\
\text { жавної підсумкової атестації. } \\
\text { Можливість повною мірою } \\
\text { реалізувати компетентнісний } \\
\text { підхід (замість знаннєвого) до } \\
\text { формулювання атестаційних } \\
\text { завдань (дослідних, практич- } \\
\text { них завдань, симуляцій тощо). } \\
\text { Зменшення витрат місцевої } \\
\text { влади для організації підве- } \\
\text { зення здобувачів освіти до } \\
\text { міста складання державної } \\
\text { підсумкової атестації (опор- } \\
\text { них закладів або регіональних } \\
\text { центрів ЗнО). } \\
\text { Стимулювання учнів до опану- } \\
\text { вання та удосконалення нави- } \\
\text { чок використання цифрових } \\
\text { технологій. }\end{array}$ & $\begin{array}{l}\text { Масовий зрив державної підсум- } \\
\text { кової атестації через неможливість } \\
\text { забезпечення технічної підтримки } \\
\text { всіх учасників і контролю від- } \\
\text { повідальних інституцій за прове- } \\
\text { денням державної підсумкової } \\
\text { атестації в даному форматі. } \\
\text { Відсутність можливості підклю- } \\
\text { чення до швидкісного та якісного } \\
\text { Інтернет-зв'язку значної частини } \\
\text { учнів через територіальне розта- } \\
\text { шування місця проживання. } \\
\text { Посилення обмеження (пору- } \\
\text { шення) рівного доступу до освіти, } \\
\text { виштовхування з освітнього сере- } \\
\text { довища менш конкурентоспромож- } \\
\text { них дітей, створення додаткових } \\
\text { переваг для подальшого навчання } \\
\text { тим учням, які мають кращі со- } \\
\text { ціально-економічні умови. } \\
\text { Поява масових апеляцій та потреби } \\
\text { в повторному складанні державної } \\
\text { підсумкової атестації через тех- } \\
\text { нічний збій під час проходження } \\
\text { підсумкової атестації онлайн. }\end{array}$ \\
\hline
\end{tabular}

Рекомендації щодо визначення стратегічних заходів з реалізації моделі державної підсумкової атестації в дистанційному форматі сформульовано за квадрантами матриці (див. табл. 5.2) [41].

Дана модель організації державної підсумкової атестації в дистанційному форматі характеризується низкою незаперечних переваг і можливостей, які роблять ії̈ привабливою для застосування, особливо під час карантинних обмежень. Незважаючи на це, оцінка вагомості взаємного впливу чинників «Слабкі риси - Загрози» свідчить про наявність нездоланних на теперішній час проблем і значних ризиків реалізації даної організаційної моделі державної підсумкової атестації. Основні загрози складають: 
- ризики правового характеру, що зумовлені посиленням обмеження, навіть порушення принципу рівного доступу до освіти всіх учнів. Це призводить до виштовхування з освітнього середовища менш конкурентоспроможних дітей та створює додаткові переваги для подальшого навчання тим учням, які мають кращі побутові й матеріальні умови; появи масових апеляцій та потреби в повторному складанні державної підсумкової атестації через технічний збій під час проходження підсумкової атестації онлайн.

- ризики, що зумовлені недоліками технічного обладнання: ймовірного масового зриву державної підсумкової атестації через неможливість забезпечення технічної підтримки всіх учасників і контролю відповідальних інституцій за проведенням державної підсумкової атестації в даному форматі; відсутністю можливості підключення до швидкісного та якісного Інтернет-зв'язку значної частини учнів через територіальне розташування місця проживання. Зважаючи на наведені вище статистичні дані та результати соціологічних досліджень й експертних оцінок щодо якості покриття території України Інтернет-зв'язком, ця загроза є доволі високою.

Виявлені загрози реалізації даної моделі проведення державної підсумкової атестації посилюються за рахунок можливого перекладання значної частки витрат щодо забезпечення учня технічними засобами для складання державної підсумкової атестації в дистанційному форматі на батьків; низького рівня сформованої в учнів цифрової компетентності та правової неврегульованості випадків повторного складання державної підсумкової атестації через технічні проблеми при спробі реалізувати дистанційну модель складання іспитів.

Оцінка вагомості взаємного впливу чинників квадранту «Сильні риси -Загрози» свідчить про ймовірну недостатність наявних сильних якостей даної моделі для реалізації заходів захисного характеру, спрямованих на блокування або зменшення прояву основних загроз масового зриву державної підсумкової атестації з технічних причин та через високу ймовірну відсутність можливості підключення до швидкісного та якісного Інтернет-зв'язку значної частини учнів, що означає порушення рівності доступу до освіти неконкурентоспроможних дітей.

Аналіз результатів оцінки чинників квадранту “Слабкі риси -Можливості» дає можливість запропонувати певні адаптаційні заходи, які в даному випадку мають бути спрямовані на недопущення додатко- 
вих фінансових витрат родин з метою забезпечення учнів технічними засобами для складання державної підсумкової атестації в дистанційному форматі та вироблення правових норм, що врегулювали 6 випадки повторного складання державної підсумкової атестації через технічні проблеми при спробі реалізувати дистанційну модель складання іспитів. Достатньо серйозну увагу варто приділити також і проблемі надмірного психологічного навантаження учнів, що виникає через підвищену відповідальність за результат складання іспитів та побоювання можливих технічних збоїв під час виконання атестаційних завдань.

За результатами проведеного аналізу дистанційної моделі реалізації державної підсумкової атестації випускників базової середньої освіти, її потенційних можливостей і загроз, які виникатимуть в Україні в умовах карантинних обмежень та створюватимуть негативний вплив на дотримання принципів доступності отримання освітніх послуг, справедливості й об'єктивності оцінювання здобутих учнями результатів навчання, виявлено певні недоліки даної моделі, що свідчить про недоцільність ії масового запровадження на всій територію України. Найбільш доцільним виявляється комбінація різних моделей організації підсумкового оцінювання здобувачів освіти на розсуд органів місцевої влади, з огляду на епідеміологічну ситуацію та технічне оснащення учасників у тому чи іншому районі або області. 


\title{
РОЗдІЛ 6
}

\section{ОРГАНІЗАЦІЙНО-ПРАВОВІ АСПЕКТИ ФУНКЦІОНУВАННЯ ЗАКЛАДІВ ЗАГАЛЬНОӦ СЕРЕДНЬОЇ ОСВІТИ ТА УПРАВЛІННЯ НИМИ В УМОВАХ ДИСТАНЦІЙНОГО НАВЧАННЯ}

\author{
6.1. ОРГАНІЗАЦІЙНО-ПРАВОВІ ЗАСАДИ \\ РЕАЛІЗАЦІЇ ДИСТАНЦІЙНОГО НАВЧАННЯ В \\ ЗАКЛАДАХ ЗАГАЛЬНОЇ СЕРЕДНЬОЇ ОСВІТИ
}

Одним із ключових моментів у забезпеченні ефективного функціонування вітчизняної освітньої галузі в умовах карантину $є$ удосконалення нормативно-правових аспектів, пов'язаних із організацією взаємодії суб'єктів освітнього процесу, зокрема, дистанційним навчанням. 3 метою оперативного врегулювання організаційно-правових засад функціонування освітньої галузі МОН України ініціювало спеціальні нормативно-правові акти. Так, листом №1/9-154 від 11.03.2020 р. керівникам закладів освіти, органам освіти та місцевого самоврядування рекомендувалося розробити заходи щодо часткового переведення працівників на роботу в дистанційному режимі [34]. Листом №1/9-161 від 13.03.2020 р. встановлювалося, що оплата праці педагогічним, науково-педагогічним працівникам закладів освіти, в яких навчання було припинено на період карантину, здійснювалася в розмірі середньої заробітної плати [102]. Наказом МОН України №406 від 16.03.2020 р. у закладах дошкільної, загальної середньої, позашкільної, професійної, фахової передвищої, вищої та післядипломної освіти на період карантину виконання освітніх програм мало забезпечуватися шляхом використанням технологій дистанційного навчання, що не передбачає відвідування закладів освіти ії здобувачами [78]. Спільний лист МОН України та ЦК профспілки працівників освіти і науки від 17.03.2020 р. містив рекомендації департаментам (управлінням) освіти і науки щодо часткового переведення працівників закладів та установ науки і освіти на роботу в гнучкому та/або дистанційному режимі, забезпе- 
чення за наявності відповідних умов проведення навчальних занять за допомогою дистанційних технологій, збереження за працівниками середнього заробітку на період карантину [82]. Листом №1/9 173 від 23.03.2020 р. визначено, що для здійснення обміну навчальними матеріалами можуть використовуватися будь-які пристрої (зокрема мобільні телефони), за допомогою яких можна організувати спільноту в соціальних мережах, мобільних додатках. Зазначалося, що матеріали можна надсилати електронною поштою, розміщувати на веб-сайтах закладів освіти (зокрема відео-уроки або покликання на них) [104]. На виконання розпоряджень та рекомендацій МОН України департаментами освіти і науки обласних державних адміністрацій були видані накази щодо особливостей функціонування закладів освіти на місцях. Запроваджувався карантин в закладах освіти усіх типів та визначалися першочергові заходи з організації роботи в умовах карантину, зокрема щодо забезпечення проведення навчальних занять за допомогою дистанційних технологій та часткового переведення працівників на роботу в дистанційному режимі [81]. Таким чином, на початковому етапі запровадження карантинних обмежень нормативно-правові акти в галузі функціонування освіти були спрямовані на першочергове внормування діяльності закладів освіти за такими напрямами: реалізація освітнього процесу; оплата праці педагогічних працівників. При цьому варто зауважити на один важливий момент щодо організації освітнього процесу в дистанційному режимі - дистанційного навчання.

Аналіз проблеми організаційно-правового забезпечення функціонування науково-освітньої галузі показав, що базове законодавство про освіту містить норми, що забезпечують можливість формування ефективних інструментів організації освітнього та наукового процесу під час карантинних обмежень. Зокрема, ст. 9. Закону України «Про освіту» встановлює дистанційну освіту як одну з форм здобуття особою освіти [79]. Згідно зі ст. 49 Закону України «Про вищу освіту» особа має право здобувати освіту в різних формах, зокрема й дистанційно [72]. Ст. 4. Закону України «Про повну загальну середню освіту» зазначає, що повна загальна середня освіта може здобуватися за різними формами, зокрема дистанційною та мережевою [80]. Дистанційна освіта визначається законодавцем як одна з форм освіти, що передбачає організацію індивідуалізованого освітнього процесу, який відбувається за опосередкованої взаємодії віддалених один від одного учасників освітнього процесу у спеціалізованому середовищі, функціонує на базі сучасних психолого-педагогічних та інформаційно-комунікаційних технологій. Особливості реалізації дистанційної освіти в 33СО 
визначаються «Положенням про інституційну форму здобуття загальної середньої освіти» (2019). Передбачено, що дистанційне навчання може бути реалізовано шляхом застосування дистанційної форми як окремої форми здобуття освіти або використання технологій дистанційного навчання для забезпечення навчання за різними формами здобуття освіти та їх поєднання. Задля організації дистанційного навчання у закладах освіти можуть створюватися класи (групи) з дистанційною формою здобуття освіти [75].

Зазначимо, що гнучкість та результативність запровадження дистанційного навчання значною мірою позиціонується з автономією закладів освіти різних рівнів. Саме автономність у виробленні механізмів організації освітнього процесу у ЗВО та наявність організаційно-педагогічного та матеріально-технічного забезпечення дистанційного навчання дало можливість університетам в достатньо короткий термін охопити ним студентську аудиторію та успішно завершити навчальний рік. Натомість практика запровадження дистанційного та змішаного навчання в 33 СО показала наявність значних труднощів. Близько $20 \% 33$ СО не змогли забезпечити повне дистанційне навчання з усіх предметів у зв'язку з відсутністю відповідного обладнання, доступу до швидкісного інтернету та недостатнім рівнем цифрової компетентності вчителів. Натомість 76\% закладів освіти організували онлайн-навчання [1]. Однією з причин такого стану, як відзначають дослідники, залишалася недостатня врегульованість організаційно-правових засад дистанційного навчання та правовідносин, що виникають між суб'єктами освітньої галузі в його процесі, трудових правовідносин щодо тривалості робочого часу, особливостей оплати праці педагогічних працівників в умовах дистанційного режиму роботи, відсутність нормативного визначення змішаного навчання тощо [63, с. 29]. Чинне на той час Положення про дистанційне навчання (2013) не вирішувало всього спектру організаційно-правових питань. Тому важливим кроком у їх вирішенні стало ухвалення нової редакції Положення (2020). Воно встановило нормативне визначення таких категорій, як: дистанційне навчання, суб'єкти дистанційного навчання, інформаційно-комунікаційні технології дистанційного навчання, синхронний та асинхронний режими взаємодії суб'єктів освітнього процесу, електронне освітнє середовище, електронні освітні ресурси з навчальних предметів (інтегрованих курсів) тощо [68]. Положення про дистанційну форму здобуття загальної середньої освіти врегульовує коло повноважень педагогічної ради та керівника закладу освіти, педагогічних працівників щодо забезпечення організації освітнього процесу під час дистанційного навчання, здійснення 
контролю за виконанням освітніх програм, визначення режиму проведення навчальних занять, облік робочого часу та оплати праці працівників, види електронних освітніх ресурсів. Також передбачено такі важливі норми, як: можливість закладів освіти створювати власні електронні освітні ресурси для забезпечення дистанційного навчання, використання інших електронних освітніх ресурсів після перевірки щодо відповідності державним стандартам, типовим освітнім і модельним навчальним програмам, мові освіти; можливість запровадження електронного журналу за умови наявності відповідного технічного забезпечення та дотримання вимог законодавства щодо захисту інформації.

Отже, викладене вище дає змогу зробити висновок про загалом сформоване організаційно-правовове забезпечення функціонування науково-освітньої галузі в умовах карантинних обмежень, а також відповідність напрямів його розбудови міжнародним трендам сучасного дослідницько-освітнього простору. Проте й донині актуальною залишається проблема удосконалення його аспектів, пов'язаних із забезпеченням захисту персональних даних суб'єктів освітнього процесу в умовах дистанційної освіти; використання ліцензійного програмного забезпечення для потреб онлайн-навчання; експертизи електронних освітніх ресурсів; унормування правового статусу електронних засобів фіксування результатів навчання та робочого часу педагогічних працівників тощо [11].

\section{2. ОСОБЛИВОСТІ УПРАВЛІНСЬКОЇ ДІЯЛЬНОСТІ КЕРІВНИКА ЗАКЛАДУ ОСВІТИ В УМОВАХ ДИСТАНЦІЙНОГО НАВЧАННЯ}

Карантин став своєрідним «лакмусовим папірцем» щодо готовності освітянської спільноти впоратися з новими викликами, не тільки адаптуватися до змін, а й шукати інші шляхи та форми організації освітнього та управлінського процесів, оволодівати новими знаннями і навичками, методиками й технологіями, забезпечувати ефективну комунікацію, ухвалюючи правильні управлінські рішення, використовувати надану Законом України «Про освіту» шкільну автономію, покладаючись на професіоналізм, згуртованість, самовідданість і готовність колективу.

16 жовтня 2020 року набуло чинності Положення про дистанційну форму здобуття повної загальної середньої освіти, затверджене наказом МОН від 08 вересня 2020 року №1115 (далі - Положення), яким оновлено умови дистанційного навчання.

У Положенні чітко, вичерпно і конкретно окреслено вимоги до організації дистанційної освіти. Новим є те, що відтепер для навчання за дистанційною формою не потрібно мати високий рівень навчальних 
досягнень (10-12 б.). Але якщо за результатами річного оцінювання рівень буде нижче 3 балів, то необхідно обирати очну форму навчання. Ще одним новим кроком $€$ те, що дистанційне навчання може бути організоване будь-якими школами, незалежно від території обслуговування. Інформація про це має бути розміщена на сайті закладу. Крім того, здобуття учнями освіти за дистанційною формою залишається виключно добровільним і потребує подання заяви про зарахування чи переведення. Якщо учень під час карантину тимчасово не відвідує заклад освіти, він не потребує переведення на дистанційне навчання, а навчається за технологіями дистанційного навчання за будь-якою формою [68].

У чому ж полягають особливості управлінської діяльності керівника закладу освіти в умовах дистанційного навчання під час карантину?

В умовах карантину, запровадження масового дистанційного навчання без попередньої підготовки і практичного досвіду виконувати навіть традиційні обов'язки досить складно. Однак у таких умовах додалася значна кількість нових, адже дистанційне навчання визначається як інструмент для реалізації індивідуальної траєкторії учня, оскільки поєднує традиційні форми навчання з цифровими технологіями; забезпечує неперервність навчання на випадок надзвичайних ситуацій. Це потребує навчання і науково-методичного супроводу педагогічних працівників, розроблення нових моделей кроків та інших навчальних занять тощо.

У межах організації дистанційного навчання на керівника закладу освіти покладається функція зі створення умов для забезпечення здобуття повної загальної середньої освіти, а також використання технологій дистанційного навчання. Заклад освіти має право в рамках власної автономії ухвалювати рішення про організацію дистанційного навчання без погодження із Засновником та визначати самостійно механізми моніторингу і контролю якості дистанційного навчання в школі. У закладі освіти може бути розроблене власне Положення про організацію дистанційного навчання, яке схвалюється педагогічною радою і затверджується керівником закладу освіти. Це додаткова відповідальність керівника закладу. Відповідно до пунктів 6, 11, 12 розділу I, пунктів 3, 5 розділу IV Положення заклад загальної середньої освіти має право визначати в освітній(ї) програмі(ах) закладу освіти форми організації освітнього процесу для забезпечення дистанційного навчання (навчальні заняття, консультації, вебінари, онлайн-форуми, віртуальні екскурсії тощо); обирати і схвалювати педагогічною радою закладу освіти конкретні електронні освітні платформи, 
онлайн сервіси та інструменти, за допомогою яких організовується освітній процес під час дистанційного навчання (Moodle, Google Classroom, Zoom тощо); забезпечити такі умови, щоб заклад освіти діяв в інтересах дитини.

У Положенні визначено, що «засновник і керівник закладу освіти забезпечують організаційну та методичну підтримку педагогічних працівників для реалізації дистанційного навчання» (пункт 12 розділу I). Це організація навчання з оволодіння навичками роботи з електронними ресурсами, ефективними методиками дистанційного навчання; планування обсягу коштів, необхідних для підвищення кваліфікації педагогічних працівників (за напрямом використання інформаційно-комунікативних (цифрових) технологій в освітньому процесі); умови для використання електронного класного журналу; визначення режиму роботи закладу освіти з урахуванням особливостей організації дистанційного навчання.

Керівник відповідає за виконання закладом освіти державних стандартів освіти на відповідному рівні повної загальної середньої освіти і при будь-якій формі навчання (частина друга ст. 44. Закону України «Про повну загальну середню освіту») [80], а також організацію освітнього процесу в синхронному та асинхронному режимах, 8 онлайн і офлайн. Саме за поєднанням очної форми і технологій дистанційного навчання в педагогічній теорії та практиці закріпився термін «змішане навчання» («комбіноване навчання», «blended learning»). Відповідно до цього ускладнюються функції керівника, оскільки йому необхідно ще здійснювати щоденний моніторинг стану здоров'я учнів і прачівників закладу, оперативно змінювати для окремих класів онлайн-форму навчання і навпаки - виконувати вимоги санітарно-гігієнічних норм під час карантину тощо.

Обов'язки керівників закладів освіти та інших членів адміністрації під час карантину регламентувалися нормативно-правовими документами, інструкціями МОН, обласних департаментів освіти і науки, органів місцевого самоврядування, засновників тощо. Такі документи підтверджували необхідність виконання Положення про дистанційну форму здобуття повної загальної середньої освіти (2020) і разом із тим конкретизували й деталізували дії керівництва закладів освіти.

Для аналізу обрано методичні матеріали м. Києва, Київської та Миколаївської областей, з якими відділ економіки і управління закладами загальної середньої освіти співпрацює та здійснює дослідно-експериментальну роботу. Зазначимо, що в усіх областях приділяється увага організації дистанційного та змішаного навчання і розробляються від- 
повідні супровідні рекомендації, ухвалюються рішення із урахуванням специфіки регіонів.

Позитивним і вартим уваги є досвід управління організацією дистанційного та змішаного навчання у м. Києві. Департамент освіти і науки м. Києва та Київський університет імені Бориса Грінченка спочатку розробили Регламент роботи під час карантину, а пізніше підготували навчально-методичний посібник "Дистанційне навчання: виклики, результати та перспективи. Порадник. 3 досвіду роботи освітян міста Києва» [15] та Путівник "Дистанційне та змішане навчання в школі» [16], у якому представлено схему розподілу повноважень між структурами Засновника, адміністраціями шкіл, вчителями та іншими категоріями учасників освітнього процесу.

Зокрема, на адміністрацію закладів загальної середньої освіти покладаються такі повноваження: аналіз і використання нормативно-правової бази з організації дистанційного навчання; аналіз готовності педагогічних працівників і учнів до дистанційного навчання; затвердження режиму роботи педагогічних працівників в умовах дистанційного навчання, розроблення й інформування щодо порядку контролю, обліку робочого часу та ведення необхідної документації; проведення роботи щодо внесення змін у календарно-тематичне планування учителів з метою інтеграції та ущільнення навчального матеріалу із затвердженням оновлених розкладів уроків і навчальних занять, складання розкладу навчальних занять, гуртків, груп продовженого дня, корекційно-розвиткових занять тощо; проведення онлайн-нарад, семінарів, вебінарів, консультацій, відеоконференцій з педагогічними працівниками і батьками; забезпечення психологічної підтримки учнів, різних форм зв'язку з батьками, організація консультаційних пунктів тощо; надання методичної і психологічної допомоги педагогам, організація наставництва; доручення щодо вивчення стану забезпеченості та наявності умов для дистанційного навчання в учнів закладу освіти та вчителів (у разі необхідності надати в користування педагогам комп'ютерну техніку закладу); моніторинг дистанційних платформ і цифрових сервісів та затвердження переліку тих, які найбільше підходитимуть учням і педагогам для дистанційного навчання з урахуванням особливостей освітнього процесу закладу освіти; забезпечення електронного документообігу, функціонування і оновлення вебсайту закладу освіти; поширення досвіду педагогічних працівників на сайті закладу освіти та інших освітніх інформаційних ресурсах.

Миколаївським ОІППО також підготовлено матеріали для організації управлінського супроводу діяльності закладів освіти в умовах каран- 
тину та організації освітнього процесу з використанням дистанційних технологій із орієнтовними зразками документів та алгоритмом діяльності керівників, зокрема: орієнтовний алгоритм діяльності керівника щодо унормування роботи закладу освіти під час карантину, підготовка наказу щодо організації освітнього процесу з використанням дистанційних технологій, платформи та сервіси тощо [ 64].

Науковцями відділу економіки і управління загальної середньої освіти було здійснено аналіз діяльності закладів загальної середньої освіти під час карантину та особливостей організації дистанційної освіти. У анкетуванні та інтерв'юванні взяли участь керівники закладів освіти, вчителі, учні та батьки експериментальних закладів освіти. Узагальнені результати дослідження представлено в роботі [60].

Були запропоновані такі питання: Чи вдалося Вашому закладу і як організувати навчання під час карантину? Які засоби зв'язку Ви використовували з педагогічним колективом, учнями, батьками? Які технології та засоби дистанційної освіти виявились ефективними? Назвіть засоби для дистанційної освіти та обґрунтуйте, які з них виявилися ефективними і чому? Що найбільше вдалося та що стало умовою успіху? Що не вдалося та чому? Які проблеми виникали і чому?

Щодо охопленості різними формами дистанційного навчання кількості учнів, то цей показник суттєво відрізняється: у Києві-78\% загалом. У ліцеях, гімназіях, деяких школах цей відсоток ще вищий - 95-97\%. Наприклад, у ліцеї «Інтелект»- 1078 учнів. Усі класи (4-11) охоплені дистанційним навчанням (м. Київ) - учнів 867. У гімназії №107 «Введенська» - 950 учнів. Не було охоплено тільки 5 учнів, яких батьки вивезли у села і з ними не вдалося налагодити зв'язок. В окремих закладах різними формами дистанційного навчання були охоплені абсолютно всі учні (Ужгородська класична гімназія) Спеціалізована школа №5 м. Горішні Плавні, спеціалізована школа №68 м. Кривого Рогу тощо.

Варто відзначити позитивні результати організації дистанційного навчання в сільських школах. Наприклад, у Трипільській опорній школі Обухівського району Київської області дистанційним навчанням охоплені всі учні; у КЗ «Чоповицький ліцей» Чоповицької селищної ради Житомирської області всього учнів - 351; дистанційним навчанням у тій чи тій формі, охоплені майже всі учні; у деяких класах є одиндва учні, які не мають ресурсів для дистанційного навчання. 3 такими дітьми вчителі проводять консультації в телефонному режимі; у Першотравневій філії Обухівського району Київської області, де навчається 44 учні, всі були охоплені дистанційним навчанням у різних формах. 
Проте в більшості закладів освіти в невеликих містах, особливо в дотаційних регіонах та більшості сільських шкіл, цей показник складав до 50\%. В окремих школах учителі вимушені були писати від руки завдання учням і приносити їх до сільської крамниці. Потім батьки чи учні забирали завдання і повертали виконані вчителеві таким же шляхом. В окремих селах немає не тільки інтернету, а й доволі часто вимикають електроенергію.

За результатами дослідження були виявлені проблеми та труднощі в організації дистанційного навчання, типові для закладів освіти всіх регіонів. Зокрема, на думку респондентів, найбільш складними у процесі реалізації дистанційного навчання $€$ такі проблеми: налагодження ефективної взаємодії з учасниками освітнього процесу; методична підготовка; недостатнє матеріально-технічне забезпечення, відсутність швидкісного інтернету і в учнів, і в окремих учителів; проблеми в матеріально-технічному забезпеченні та відповідній підготовці до умов дистанційного навчання як вчителів, так і учнів; відсутність Інтернет-зв'язку та відсутність комп'ютерної техніки в учасників освітнього процесу. Не вдалося налагодити якісне дистанційне навчання на самому початку карантину. Був відсутній досвід організації дистанційного навчання, виникали проблеми із платформами. У відповідях респонденти зазначили: «Через навантаження часто були збої», «Не бачиш усіх учнів»; «Потрібно знаходити новий матеріал, щоб зацікавити учня і вигадати, щоб не списували; проблеми з доступом до мережі учнів». Заважала пасивність деяких учнів та їх батьків. Не вдалося забезпечити мотивацію окремих учнів до самоосвіти.

Аналізуючи відповіді керівників закладів освіти, відзначаємо значне посилення контролю з боку відділів та управлінь освіти, перешкоди до автономії закладів освіти та керівників, надмірну кількість організаційних питань.

На запитання: «Що найбільше вдалося та що стало умовою успіху?» представники закладів освіти зуважили, що вже весною 2020 року загалом вдалося організувати дистанційне навчання (його ключові елементи). При цьому організуватися, опанувати нові технології за короткий термін учителям допомогли самоорганізація, самодисципліна, відповідальність, а також відвідування сертифікованих предметних вебінарів. (Всеосвіта, На урок); проведення Zoom -конференцій, використання сервісу LearningApps.org тощо).

Умовою успіху в багатьох закладах стала чітка організація, контроль і розпорядження та допомога з боку адміністрації школи, наявність 
електронного журналу та щоденника, i, звичайно, творчий підхід кожного вчителя.

Найбільший успіх полягає в тому, що майже всі учасники освітнього процесу змогли в досить екстремальних умовах організувати роботу в дистанційному режимі.

На жаль, траплялися випадки, коли заклади освіти залишаються сам на сам з проблемами, які не завжди можуть вирішити самостійно. Респонденти дослідження вважають, що в першу чергу необхідно забезпечити педагогічних працівників технічними засобами, повернути пільги за електроенергію, надати можливості безкоштовного користування інтернетом, створити єдину освітню електронну платформу дистанційної освіти та Всеукраїнську базу відеоуроків з усіх предметів. Потребує усунення значний розрив у технічному забезпеченні дистанційного навчання у мегаполісах та маленьких містах і селах. Актуальним є погодження із провідними мобільними операторами запровадження спеціальних тарифних планів для вчителів та учнів на період дистанційної освіти, а також укладання угод про співпрацю з Укрпоштою щодо підтримки та допомоги в організації дистанційного навчання для учнів у невеликих населених пунктах шляхом розсилки дидактичних матеріалів тощо.

Організація масового дистанційного навчання потребувала швидких та дієвих практичних кроків і рішень, переосмислення підходів до організації навчання з урахуванням умов, спричинених карантином. Керівнику та його управлінській команді важливо глибоко усвідомити, що для того, щоб заклад освіти працював як злагоджений механізм, необхідно постійно навчатися, перебувати у пошуку і не боятися запроваджувати інновації.

Важливими інструментами організації дистанційного навчання є: сайт закладу освіти, системи електронного обліку відвідування та оцінювання, неперервне навчання педагогічного колективу, спільні групи для спілкування у месенджері та інших засобах усіх учасників освітнього процесу, постійний аналіз результативності за допомогою дистанційних опитувань, моніторингових досліджень.

Ефективна система управління освітнім процесом в умовах дистанційного навчання передбачає чітке визначення його цілей, планування та організацію роботи, чіткий розподіл завдань, пошук додаткових ресурсів, навчання колективу, упровадження, аналіз результатів організації дистанційного навчання та його коригування, прийняття управлінських рішень. 
На підготовчому етапі здійснюється моніторинг наявності технічних засобів учителів та здобувачів освіти, а також визначення рівня спроможності користуватися необхідною технікою для організації синхронного дистанційного навчання. До повноважень педагогічної ради закладу освіти належить ухвалення рішень щодо організації освітнього процесу в умовах карантину, відповідних змін розкладу та режиму занять, регулювання тривалості онлайн-уроків, обсягу та періодичності домашніх завдань, обліку проведених занять та оцінювання. Вони затверджуються наказами керівника та доводяться до відома усіх учасників освітнього процесу.

Важливим складником є навчання педагогічного колективу використання ефрективних технологій дистанційного навчання, налагодження професійних зв'язків між педагогами, обмін педагогічним досвідом.

Доцільним також є системний збір інформації управлінською командою (анкетування, спостереження за онлайн-уроками, співбесіди, бліцінтерв'ю, консультації, контроль за оцінюванням тощо), на основі аналізу якої керівник здійснює об'єктивну оцінку переваг та труднощів в організації дистанційного навчання [15, с. 52-57].

Відтак, ключовим завданням керівника $\epsilon$ створення умов для вибору оптимального варіанту організації дистанційного навчання, відповідних методів та форм, що враховують можливості конкретного закладу освіти.

Досвід показав, що ефективна освіта в онлайн-режимі під час карантину - це наполеглива співпраця всіх учасників освітнього процесу, завдяки якій дистанційне навчання перетворюється в необмежений простір для творчості та академічної свободи вчителя й учнів. 


\section{ЗАГАЛЬНІ ВИСНОВКИ ТА РЕКОМЕНДАЦІЇ}

Здійснений фахівцями Інституту педагогіки НАПН України аналіз, результати якого представлено в збірнику, дав змогу виявити актуальні методологічні та психолого-педагогічні проблеми організації й упровадження дистанційного навчання як окремих предметів, так і системи загальної середньої освіти загалом. Отримані результати можуть стати підґрунтям для розроблення змісту, методів і прийомів дистанційного навчання, формування інформаційно-комунікаційної (цифрової) компетентності вчителів і здобувачів освіти; добору технологій щодо навчання, контролю й оцінювання навчальних досягнень учнів у процесі формування ключових компетентностей і наскрізних умінь; створення методичних рекомендацій щодо впровадження дистанційного та/або змішаного навчання; зміни підходів до змісту й організації підвищення фахового рівня педагогів.

Спільною для більшості країн світу проблемою щодо реалізації дистанційного навчання під час пандемії $€$ забезпечення учасників освітнього процесу необхідним технічним устаткуванням. Відсутність комп'ютерного обладнання в родині учня та у вчителя або його невідповідність сучасним вимогам, а також відсутність або погана якість інтернету (мобільного підключення) є однією з найбільш суттєвих перешкод.

Відтак основні зусилля спрямовуються на залучення ресурсної бази інтернет-компаній, освітніх платформ, медіа та поштового зв'язку для впровадження дистанційної форми навчання. В деяких країнах вирішити проблему технічного забезпечення учасників освітнього процесу намагаються шляхом передачі на період дистанційного навчання наявного в закладах освіти комп'ютерного обладнання учням і вчителям. Водночас ефективність цих заходів $\epsilon$ різною, що зумовлено фінансовими можливостями та національними особливостями.

3 огляду на це одним із пріоритетних завдань в Україні $\epsilon$ забезпечення державної підтримки учнів і вчителів закладів загальної середньої освіти комп'ютерним обладнанням для реалізації дистанційного навчання.

Актуальним є створення доступної загальнонаціональної ліцензованої платформи для підтримки дистанційного навчання, яка 6 акумулювала навчальні матеріали, тренінги, вебінари для вчителів, учнів, батьків на період дистанційного навчання, програмне забезпечення онлайн навчання, сумісне з мобільними телефонами та смартфонами, була б ін- 
тегрованою до глобальної комп'ютерної мережі та виконувала функції комунікативного центру.Варто також провести широку інформаційну кампанію серед учасників освітнього процесу щодо можливостей освітньої платформи для забезпечення дистанційного навчання.

Одним із першочергових завдань $€$ подальше вдосконалення нормативно-правового забезпечення дистанційного навчання: нормативне регулювання дистанційної освіти; унормування на державному рівні вимог до організації дистанційного навчання в закладах загальної середньої освіти; чітке визначення прав і обов'язків суб'єктів освітнього процесу в умовах дистанційного навчання. 3 метою зменшення навчального навантаження на учнів та удосконалення системи обліку роботи вчителя під час дистанційного навчання потребують визначення та затвердження нові норми часу на виконання різного роду навчальних і професійних завдань учасниками освітнього процесу, а також розроблення санітарно-гігієнічних вимог щодо організації та часу проведення навчальних занять для учнів різних вікових категорій в он-лайн режимі.

Потребують обґрунтування концептуальні основи дистанційного навчання: розроблення й апробування концепції дистанційного навчання; розроблення структури дистанційного навчання для забезпечення його ефективності (електронна версія бально-рейтингової системи; застосування практичних відео посібників при проведенні онлайнових уроків тощо); визначення конкретних вимог щодо його організації для всіх здобувачів освіти; розроблення детальних методичних рекомендацій з усіх предметів щодо дистанційного навчання; розроблення й впровадження критеріїв оцінювання академічної успішності учнів з усіх предметів за дистанційного навчання; розроблення, апробування, впровадження інноваційної системи діагностики і моніторингу якості дистанційного навчання; впровадження на постійній основі змішаного навчання учнів закладів загальної середньої освіти. Постає також необхідність посилення загальношкільного підходу до розв'язання проблем, що виникають при організації й проведенні дистанційного навчання, та забезпечення єдності педагогічних вимог.

Одним із важливих чинників ефективної реалізації дистанційного навчання $€$ розгортання системи підготовки педагогів до роботи в умовах карантинних обмежень, запровадження спеціальних програм із підготовки вчителів до організації та проведення дистанційного навчання, створення та впровадження відповідних освітніх програм.

Особливу увагу варто приділити змістовому наповненню дистанційного навчання: створення методичних посібників, електронних підручників, тематичних сайтів та бібліотек з методичними матеріалами; підготов- 
ка розробок для вчителів щодо проведення онлайнових уроків, віртуальних екскурсій, пам'ятними місцями, музеями України, Європи, світу.

Успішна реалізація дистанційного навчання загалом та оцінювання результатів навчальної діяльності здобувачів загальної середньої освіти в умовах карантинних обмежень та інших непередбачуваних обставин, зокрема, потребує попередньої підготовчої роботи, а саме: створення єдиного банку еквівалентних (однакового рівня складності, однотипних) завдань для забезпечення рівності умов, адекватності змісту освіти та справедливості в оцінювання навчальних досягнень здобувачів освіти; створення при закладах освіти центрів (серверів) для підключення до єдиної освітньої платформи для забезпечення дистанційного навчання; забезпечення дітей, що мають меншу конкурентну спроможність, зокрема із малозабезпечених і багатодітних родин, родин, що проживають у відділених гірських районах, тимчасово переміщених осіб технічним обладнанням (ноутбуками, web-камерами) для забезпечення навчання у дистанційному режимі, навіть і в період не карантинних обмежень; запровадження пільгових тарифів для сплати мобільного Інтернет-зв'язку для дітей шкільного віку, особливо на період дистанційного.

Варто наголосити й на ролі мас медіа (всеукраїнських, регіональних, місцевих) у пропагуванні ідей, принципів, успіхів дистанційного навчання, поширення кращих практик освітніх закладів і досвіду вчителів.

Доцільним і своєчасним $є$ і національне моніторингове дослідження, метою якого має стати виявлення чинників впливу на якість освіти та обсяги опанування навчального матеріалу учнями в умовах змішаного та дистанційного навчання.

Аналіз здійснено на науково обґрунтованій теоретичній базі, який підтверджено належною апробацією, проте потребує подальших наукових розвідок і технологічного розроблення проблеми запровадження дистанційного навчання, а запропоновані підходи та методичні поради щодо використання електронних освітніх ресурсів можуть слугувати чіткими рекомендаціями для застосування їх в освітній практиці.

Отже, запровадження ефективного дистанційного навчання в закладах загальної середньої освіти України потребує консолідації інтелектуальних, організаційних, матеріально-технічних ресурсів і мобілізації зусиль Міністерства освіти і науки України, суб'єктів освітнього процесу, науково-методичних установ, органів виконавчої влади, місцевого самоврядування та об'єднаних територіальних громад. 


\section{ВИКОРИСТАНІ ДЖЕРЕЛА}

1. Аналітична довідка щодо організації дистанційного навчання у закладах загальної середньої освіти в умовах карантину (за результатами онлайн-анкетування учасників освітнього процесу). Державна служба якості освіти України. URL : https://bit.ly/3I3CTDZ.

2. Аналітична записка «Про стан онлайн навчання учнів історії в період карантину в Україні (березень-травень 2020 року)» (електронне видання) / Олена Пометун, Тетяна Ремех, Нестор Гупан, Петро Мороз, Вікторія Кришмарел, Юлія Малієнко, Тетяна Мацейків, Ірина Мороз. К. : Педагогічна думка, 2020. 26 c. URL : https://lib.iitta.gov.ua/722287/.

3. Биков В. Ю. Дистанційна освіта: актуальність, особливості і принципи побудови, шляхи розвитку та сфера застосування. Інформаційне забезпечення навчально-виховного процесу: інноваційні засоби і технології: Колективна монографія. К. : Атіка, 2005. 252 с.

4. Бондаренко Н. В. Як збалансувати цифрове й гуманітарне в освіті. The world of science and innovation. Abstracts of the 2 nd International scientific and practical conference. Cognum Publishing House. London, United Kingdom. 2020. Pp. 267-277. URL : http://lib.iitta.gov.ua/id/eprint/721818.

5. Боремчук Л. І. Дистанційне навчання як педагогічна технологія. XIV Міжнародна інтернет-конференція Advanced technologist of science and education URI : https://bit.ly/2TFch2A.

6. Вивчаємо математику разом з Наталією Листопад. URL : https://www. facebook.com/groups/424261038218074.

7. Відділ початкової освіти імені О.Я. Савченко Інституту педагогіки НАПН України. URL : https://www.facebook.com/groups/pochosvita.

8. Відповідь світової спільноти на виклики COVID-19 в освіті (лютий-червень 2020 р.). : оглядове видання / НАПН України, Ін-т педагогіки НАПН України ; упоряд.: О.І. Локшина, О.З. Глушко, А.П. Джурило, С.М. Кравченко, Н.В. Нікольська, М.М. Тименко, О.М. Шпарик ; [наук. ред. О.І. Локшина] Київ : Авторитет, 2020. 36 c. URL : https://doi.org/10.32405/978-966-97763-0-42020-36.

9. Віртуальний STEM-центр Малої академії наук України. URL : https://stemua. science/.

10. Вчимо вдумливо читати і розуміти прочитане. URL : https://www.facebook. com/groups/1319146588474256.

11. Головко С.Г. Організаційно-правові засади функціонування науково-освітньої галузі України в умовах пандемії COVID-19. Наукові праці Національного авіаційного університету. Київ: НАУ, 2021. №1(58). С. 208-215. (Серія: Юридичний вісник «Повітряне і космічне право»). 
12. Горошкіна О. М., Бондаренко Н. В., Попова Л. О. Методика компетентнісно орієнтованого навчання української мови учнів ліцею на рівні стандарту: метод. посібник. Київ: КОНВІ ПРІНТ, 2020. 128 с. URL : http://lib.iitta.gov. ua/id/eprint/722967.

13. Гурак Руслан. Дистанційне навчання - це виклик для української освіти під час пандемії. Державна служба якості освіти України. URL : https:// bit.ly/3iVBVuz.

14. Динаміка користування Інтернет в Україні: Прес-реліз Київського міжнародного інституту соціології. URL : https://bit.ly/3zAaEnh.

15. Дистанційне навчання: виклики, результати та перспективи. Порадник. 3 досвіду роботи освітян міста Києва : навч.-метод. посіб. / Упоряд.: Воротникова І.П,. Чайковська Н.В. - К. : Київ. ун-т ім. Б. Грінченка, 2020. 456 с.

16. Дистанційне та змішане навчання в школі. Путівник / Упоряд. Воротникова І.П. К.: Київ. ун-т ім. Б. Грінченка. 2020. 48 с.

17. Дослідження стану реалізації дистанційного навчання в Україні: (березень - квітень 2020 р.). Центр інформаційної освіти ПРО.CBIT. URL : https:// bit.ly/3iNRbcM.

18. Дослідження щодо готовності педагогічних працівників до реалізації Концепції Нової української школи: аналітичний звіт. Київ : МОН, Інститут освітньої аналітики, 2020. 47 с. URL : https://bit.ly/3cNdOu4.

19. Доступ домогосподарств України до Інтернету (за даними вибіркового опитування домогосподарств, проведеного у січні 2019 року). Статистичний збірник. Київ: Державна служба статистики України, 2019. URL: https:// bit.ly/3wtEQOR.

20. Единое национальное тестирование начнется 21 июня. Білімді Ел. Образованная страна. Республиканская образовательная общественно-политическая газета. URL : https://bilimdinews.kz/?p=109641.

21. Електронна бібліотека НАПН України. URL : https://lib.iitta.gov.ua/view/ divisions/ped/2020.type.html.

22. Запитання. Київський регіональний центр оцінювання якості освіти. URL : https://kyivtest.org.ua/zapytannya/.

23. Изменения в законе об образовании в связи с чрезвычайным положением. Министерство образования, науки, культуры и спорта Республики Армения. URL: http://escs.am/ru/news/6595.

24. Іванців Анастасія. Залежність від людськості. Як школа справляється з викликами карантину та онлайн-освіти. LB.ua. 2020. URL : https://bit.ly/3q0J8uJ.

25. Іванюк І. В., Овчарук О. В. Результати онлайн опитування готовність і потреби вчителів щодо використання цифрових засобів та ІКТ в умовах карантину: 2021: аналітичний звіт. Київ : ІІТЗН НАПН України. 2021. 55 с. URL : https://bit.ly/3gDxEsS.

26. Ільченко В.Р., Гуз К.Ж. Модернізація змісту освіти як національна проблема. Всеукраїнський науково-практичний журнал "Директор школи, ліцею, гімназії» №6. 2018. С. 35-38. 
27. Інтелектуальні ігри: ще один крок до формування читацької грамотності (23 лютого 2021 р.). Нове бачення сучасних шляхів формування читацької компетентності засобами інтелектуальних ігор URL : https://www.facebook. com/105956520764555/videos/173829670976544).

28. Інтернет-ресурси для створення математичного навчання та ігрового змісту для молодших школярів. URL : https://bit.ly/3gP2Syz.

29. Концепція розвитку дистанційної освіти в Україні. URL : http://www. osvita.org.ua/distance/pravo/00.html.

30. Корпорація Ранок. URL : https: //www.youtube.com/channel/UCkCUYEVb4tIr3MbLPXuEag/videos.

31. Крячко І. П., Інтернет-підтримка вивчення шкільного курсу астрономії, Фізика в школах України. №15-16 (115-116). С. 50-52. 2008.

32. Крячко І. П.. Виконання навчальних астрономічних спостережень на телескопах з віддаленим доступом. Інформаційні технології і засоби навчання. т. 50, №6. С. 50-56. 2015.

33. Крячко І., Нове в астрономії : книга для вчителя та учня. К. : Шк. світ, 2013. 104 c.

34. Лист Міністерства освіти і науки України від 11 березня 2020 р. №1/9-154. URL: https://mon.gov.ua/storage/app/media/news/\%D0\%9D\%D0\%BE\%D0\% B2\%D0\%B8\%D0\%BD\%D0\%B8/2020/03/11/1_9-154.pdf.

35. Літвінцева Наталя. НУШ. Дистанційні уроки URL : https://www.youtube. com/channel/UCBvaTzYIDfyUulsgzZRxzcg.

36. Лукіна Т. Мета як основа для визначення моделі державної підсумкової атестації випускників основної школи. Impact of modernity on science and practice : Abstracts of XII international scientific and practical conference. Edmonton, Canada, 2020. Pp. 450-453. URL: https://bit.ly/3gAeKTA.

37. Лукіна Т.О. Державне управління якісю загальної середньої освіти в Україні. К. : Вид-во НАДУ, 2004. 292 с.

38. Лукіна Т.О. Дистанційне навчання в загальній середній освіті в Україні: доступність та результативність в умовах пандемії. Вісник післядипломної освіти: зб. наук. праць. «Серія «Соціальні та поведінкові науки». 2021. Вип. 16(45). С. 224-252. URL : https://bit.ly/3gDxT7g.

39. Лукіна Т.О. Зміна моделі державної підсумкової атестації випускників гімназій: організаційно-методичний аспект. Український педагогічний журнал. 2020. № 2. C. 42-50. URL : https://bit.ly/3wyEdmZ.

40. Лукіна Т.О. Готовність випускників основної школи до запровадження нового формату державної підсумкової атестації: за результатами дослідження. Реалізація компетентнісно орієнтованого навчання в освіті: теоретичний і практичний аспекти : зб. наукових праць за матеріалами Міжнар. наук.-практ. конф., м. Київ, 4 лист. 2019 р. Київ, 2019. С. 182-184. URL : http://undip.org.ua/upload/iblock/1b2/zbirnyk.pdf.

41. Лукіна Т.О. Державна підсумкова атестація випускників гімназій в умовах карантинних обмежень освітнього процесу. Вісник післядипломної освіти : зб. 
наук. праць. 2020. Вип. 13(42). С. 169-202. (Серія «Соціальні та поведінкові науки»).URL : https://doi.org/10.32405/2522-9931-2020-13(42)-169-202.

42. Лукіна Т.О. Державна підсумкова атестація випускників гімназій: проблема визначення концептуальної основи. Оцінювання досягнень здобувачів загальної середньої освіти: сучасні виклики та перспективи : зб. наук. пр. / ред. кол. І. Б. Вашеняк (гол.) та ін. Хмельницький : Видавництво ХОІППО, 2020. С. 38-47. URL: https://bit.ly/35rMdKM.

43. Лукіна Т.О. До проблеми запровадження технологій незалежного оцінювання результатів навчання у Новій українській школі: за результатами емпіричного дослідження. Освіта і формування конкурентоспроможності фахівців в умовах євроінтеграції : збірник тез доп. III Міжнар. наук.-практ. конф. (м.Мукачево, 24-25 жовтня 2019 р.) / ред. кол.: Т. Д. Щербан (гол.ред.) та ін. Мукачево , 2019. С. 293-294. URL: https://bit.ly/2S1TJsE.

44. Лукіна Т.О. Доступність освіти як показник результативності державного управління освітою в Україні. Вісник Національної академії державного управління при Президентові України. 2013. Вип. 3. С. 114-120. URL: https://bit.ly/2TCvYI7.

45. Лукіна Т.О. Доступність освіти. Освіта дорослих : енциклопедичний словник / за ред. В. Г. Кременя, Ю. В. Ковбасюка ; упоряд.: Н. Г. Протасова, Ю. О. Молчанова, Т. В. Куренна ; ред. рада: В. Г. Кремень, Ю. В. Ковбасюк, Н. Г. Протасова та ін. ; Нац. Акад. пед. наук України, Нац. Акад. держ. упр. при Президентові України [та ін.]. Київ : Основа, 2014. С. 114.

46. Лукіна Т.О. Загрози реалізації державної політики протидії обмеженню рівного доступу до освіти в Україні. Вісник післядипломної освіти. Серія «Управління та адміністрування»: зб. наук. праць. 2019. Вип. 3 (38). C. 10-33. URL: https://bit.ly/3wzoMLz.

47. Лукіна Т.О. Зміна моделі державної підсумкової атестації випускників гімназії: проблеми визначення переваг. Формування ключових і предметних компетентностей засобами сучасних освітніх технологій : матеріали Міжнар. наук.-практ. конф., присвяченої 90-річчю Криворізького держ. педагогічного ун.-ту та 60-річчю психолого-педагогічного факультету, м. Кривий Ріг, 21 лист. 2019 р. Кривий Ріг , 2019. С. 26-30.

48. Лукіна Т.О. ЗНО випускників гімназій як інструмент успішної реалізації політики рівного доступу до освіти в Україні. Сучасний рух науки : тези доп. VIII міжнар. наук.-практ. інтернет-конф., м. Дніпро, 3-4 жовт.2019 р. Дніпро, 2019. т.2. С. 417-422. URL : https://bit.ly/3q4s86B.

49. Лукіна Т.О. Підсумкові випробування здобувачів базової освіти: світові тенденції та українські досягнення. Proceedings of the 3rd International Scientific and Practical Conference "Science and Practice: Implementation to Modern Society» (Manchester, March 16-18, 2020). Manchester, Great Britain: Peal Press Ltd., 2020. pp. 48-52. URL: https://bit.ly/3zHwdT1.

50. Лукіна Т.О. Проблема визначення функцій державної підсумкової атестації здобувачів базової загальної середньої освіти. Анотовані результа- 
ти науково-дослідної роботи Інституту педагогіки за 2020 рік. Київ : Інститут педагогіки НАПН України, Педагогічна думка, 2020. С. 106-107. URL: https://bit.ly/2UdPCdV.

51. Лукіна Т.О. Реалізація освітньої державної політики України: аспект доступності освіти. Статистика України. 2003. № 4. С. 40-44.

52. Любомира Мандзій: Епідеміологічна ситуація дозволяє провести ЗНО-2020 25 червня - 17 липня, пункти тестування готові провести його у безпечних умовах. Міністерство освіти і науки України . URL: https://bit.ly/3wtf511.

53. Математика. Ранок. Пілот. URL : https://www.facebook.com/ groups/114415665917818.

54. МОН готове провести 3 НО у безпечних умовах, його скасування $€$ неприпустимим і може створити корупційні ризики під час вступу - заява $\mathrm{MOH}$. Міністерство освіти і науки України . URL : https://bit.ly/3clrOVE.

55. Назаренко Т. Г. Формування в учнів географічної компетентності в умовах дистанційного навчання. Географрія та економіка в рідній школі - 2020 р. №5 - С. 15-21.

56. НазаренкоТ. Г. Цифрова компетентність як умова формування в учнів географічної компетентності. Географія та економіка в рідній школі, №11. C. 26-32.

57. Науменко С. О. Вітчизняний та зарубіжний досвід реалізації сертифікаційного оцінювання здобувачів середньої освіти в умовах пандемії COVID-19. Science and Practice: Implementation to Modern Society : Proceedings of the 6th International Scientific and Practical Conference (August 16-18, 2020). Manchester, Great Britain : Peal Press Ltd., 2020. P. 44-53. URL: https://lib. iitta.gov.ua/721643/.

58. Новації, графік, предмети. ЗНО/ДПА-2021. Український центр оцінювання якості освіти . URL: https://testportal.gov.ua/novatsiyi-grafik-predmety/.

59. Овчарук, О.В., Іванюк, І.В. Результати он-лайн опитування «Потреби вчителів у підвищенні фахового рівня з питань використання цифрових засобів та ІКТ в умовах карантину»: аналітичні матеріали. Київ: ІІТЗН НАПН України, 2020. URL: https://bit.ly/3xsondY.

60. Онаць О. М., Топузов М. О., Попович Л. М. Виклики дистанційного навчання під час карантину в підручнику для керівника. Проблеми сучасного підручника: збірник матеріалів Міжнародної науково-практичної інтернет-конференції (електронне видання), 28-29 травня 2020 р., м. Київ. К. : Педагогічна думка, 2020. С. 68 -72. URL : https://bit.ly/3d1tAS4.

61. Онопрієнко О. В. Дидактико-методичні засади контролю й оцінювання навчальних досягнень молодших школярів: монографія. Київ, 2020. URL : http://undip.org.ua/news/library/monografii_detail.php?ID=10167.

62. Організація дистанційного навчання в школі: методичні рекомендації / уклад. А. Лотоцька, О. Пасічник. МОН України. 2020. URL : https://mon.gov. ua/storage/app/media/zagalna\%20serednya/metodichni\%20recomendazii/2020/ metodichni\%20recomendazii-dustanciyna\%20osvita-2020.pdf. 
63. Організація освітнього процесу в школах України в умовах карантину: аналітична записка / Гриневич Л. та ін. Київ: Київський університет імені Бориса Грінченка, 2020. 76 с.

64. Організація освітнього процесу із застосуванням технологій дистанційного навчання у 2020/2021 навчальному році : методичні рекомендації / за заг. ред. В. І. Шуляра. Миколаїв : ОІППО, 2020. 108 с.

65. Освіта в Україні: виклики та перспективи. Інформаційно-аналітичний збірник. Київ: МOH, ДНУ «Інститут освітньої аналітики», 2020. 293 с. URL: https://bit.ly/3iNDBGf.

66. Освіта і пандемія: що українці думають про дистанційне навчання та як оцінюють ЗНО. Фонд "Демократичні ініціативи імені Ілька Кучерева». 31 липня 2020. URL : https://bit.ly/3wyjkbD.

67. Первый единый экзамен будет проведен 8 июня. ЦОТ. Armtimes.com : caŭm. URL : https://armtimes.com/ru/article/208889.

68. Положення про дистанційну форму здобуття повної загальної середньої освіти: наказ М-ва освіти і науки України від 08 вересня 2020 р. №1115. URL: https://zakon.rada.gov.ua/laws/show/z0941-20\#Text.

69. Пометун, О. І., Ремех, Т. О. Онлайн-навчання історії: виклики і проблеми. Комп'ютер у школі та сім'ї. 2020, №3, C. 8-14. URL : http://lib.iitta. gov.ua/id/eprint/723629.

70. Попова Л. О. «Перевернутий клас» - модель чи метод змішаного навчання української мови в ліцеї. Стратегічні пріоритети філології й лінгводидактики в умовах реформування освітньої системи в Україні: збірник праць (за матеріалами Всеукр. наук.-практ. конф. (10 квітня 2020 р., м. Старобільськ)) / ДЗ «Луган. нац. ун-т імені Тараса Шевченка». Старобільськ, 2020. С. 52-54. URL : http://lib.iitta.gov.ua/id/eprint/720873.

71. Попова Л. Проблеми й перспективи організації дистанційного навчання української мови. Українська мова і література в школі. 2020. №3 C. 16-19. URL : http://lib.iitta.gov.ua/id/eprint/723303.

72. Про вищу освіту: Закон України від 01 липня 2014 р. №1556-VII. URL: https:// zakon.rada.gov.ua/laws/show/1556-18.

73. Про внесення змін до деяких законів України щодо окремих питань завершення 2019/2020 навчального року : Закон України від 18.06.2020 р. № 725-IX. Верховна Рада України. Законодавство України : веб-сайт. URL: https://zakon.rada.gov.ua/laws/show/725-20\#Text.

74. Про затвердження Положення про дистанційне навчання» (із змінами, внесеними згідно з наказами Міністерства освіти і науки №660 від 01.06.2013 та №761 від 14.07.2015): Наказ Міністерство освіти і науки України від 25.04.2013 р. №46. URL: https://zakon.rada.gov.ua/laws/show/z0703-13\#Tex.

75. Про затвердження Положення про інституційну форму здобуття загальної середньої освіти: наказ М-ва освіти і науки України від 23 квітня 2019 р. №536. URL: https://zakon.rada.gov.ua/laws/show/z0338-21\#Text. 
76. Про затвердження Порядку проведення державної підсумкової атестації» (із змінами, внесеними згідно з Наказами Міністерства освіти і науки №221 від 18.02.2019 №246 від 19.02.2020): Наказ Міністерства освіти і науки України від 07.01.2018 р. №1369. URL: https://zakon.rada.gov.ua/ laws/show/z0008-19\#Text.

77. Про звільнення від проходження державної підсумкової атестації учнів, які завершують здобуття початкової та базової загальної середньої освіти, у 2020/2021 навчальному році : Наказ Міністерства освіти і науки України від 03 березня 2021 р. № 273. Міністерство освіти і науки України : веб-сайт. URL: https://bit.ly/2RYS6Mshttps://bit.ly/2RYS6Ms.

78. Про організаційні заходи для запобігання поширенню коронавірусу COVID-19: наказ М-ва освіти і науки України від 16 березн. 2020 р. №406. URL: https://vin-osvita.gov.ua/uploads/documents/MON406_2020.pdf.

79. Про освіту: Закон України від 05 вересн. 2017 р. №2145-VIII. URL: https:// zakon.rada.gov.ua/laws/show/2145-19\#Text.

80. Про повну загальну середню освіту: Закон України від 16 січн. 2020 р. №463-IX. URL: https://zakon.rada.gov.ua/laws/show/463-20\#Text.

81. Про призупинення освітнього процесу в закладах області: наказ Департаменту освіти і науки Вінницької обласної державної адміністрації від 12 березня 2020 р. №127. URL: https://vinrvo.gov.ua/index.php/nakazu_19-20.

82. Про умови та оплату праці працівників закладів освіти і науки в умовах карантину: Спільний лист Міністерства освіти і науки України та ЦК профспілки працівників освіти і науки України від 17 березн. 2020 p. URL: https:// vin-osvita.gov.ua/uploads/documents/1_9-162.pdf.

83. Провести 3 НО на стадіоні неможливо, - МОН. Освіта.иа : веб-сайт. URL: https://osvita.ua/test/73240/.

84. Прохоренко О., Люлькова Ю. Особливості навчально-методичного забезпечення освітнього процесу в умовах карантину. Проблеми сучасного підручника: збірник наукових праць [ред. кол.; голов. Ред. - О. М. Топузов]. Київ : Педагогічна думка, 2020. Вип. 25. С.112-121.

85. Радчук Олександр. Навчальний рік в онлайні: про наслідки змін в освіті у період карантину. Слово і діло. Аналітичний портал. 15 січня 2021. URL : https://bit.ly/3xqyRKK.

86. Результати опитування батьків «Навчання дітей під час карантину». Ocвітній омбудсмен України. 08-13 квітня 2020 p. URL : https://bit.ly/3wM4gaN.

87. Сирбу О., Назаренко Ю., Когут І. Коронавірус та освіта: аналіз проблем і наслідків пандемії. 5 листопада 2020. URL : https://bit.ly/3vsJoDX.

88. Сіпій В. В. Формування політехнічних умінь в процесі навчання фізики учнів основної школи з використанням смартфонів Наукові записки. Кропивницький : РВВ ЦДПУ ім. В. Винниченка, 2017. Вип. 12. Ч. І. С. 92-96. (Серія : Проблеми методики фізико-математичної і технологічної освіти).

89. Сучасні методи дистанційного та змішаного навчання на уроках української і зарубіжної літератур (23 березня 2021 р.).URL : https://bit.ly/3vQGpW2). 
90. Теоретичні та методичні засади інтеграції природничо-наукової освіти основної школи. : посібник / Ільченко В.Р., Гуз К.Ж., Ільченко О.Г. та ін. К.: Видавничий дім «Сам», 2017. 320 с.

91. Трубачева С. Е. Психолого-педагогічні особливості проектування освітнього середовища гімназії. Науковий вісник Ужгородського університету. Серія: «Педагогіка. Соціальна робота». 2019. Випуск 2 (45). С. 205-209.

92. Трубачева С., Замаскіна П. Проєктування освітнього середовища гімназії з урахуванням особливостей дистанційного навчання. Науковий вісник Ужгородського університету. 2020. Вип. 2 (47). С.195-199. (Серія: «Педагогіка. Соціальна робота»).

93. Трубачева С.Е. Можливості підручника в забезпеченні педагогічної взаємодії в умовах дистанційного навчання. Проблеми сучасного підручника: збірник наукових праць [ред. кол.; голов. Ред. - О. М. Топузов]. Київ : Педагогічна думка, 2020. Вип. 25. С.192-200.

94. Трубачева С. Е., Мушка О. В. Організаційно-педагогічні особливості проєктування дистанційної освіти в умовах карантину. Український педагогічний журнал. 2020. №3. С. 58-65.

95. Уранкаева Ж. Революция в проведении ЕНТ в Казахстане: что изменится с 2021 года. Sputnik Kazakhstan/Kazakh. URL: https://bit.ly/3wxDKSo.

96. Федорів Михайло. Понад 5,5 мільйонів українців не можуть отримати якісний фіксований інтернет. 30 липня 2020. URL : https://www.pravda.com.ua/ columns/2020/07/30/7261199.

97. Формування ключових та предметних компетентностей через творчі завдання та запитання. URL : http://surl.li/uozt).

98. Фролов И. Н. E-didactics как теоретический базис електронного обучения. В мире научных открытий. 2011. T. 14. № 2. С. 135-142. URL: http:// method-lip.livejournal.com/363.html.

99. Хроніки відповідей національних систем освіти країн світу на COVID-19. Педагогічна компаративістика і міжнародна освіта - 2020: глобалізований простір інновацій : матеріали IV Міжнар. наук.-практ. конф., Київ, 28 травня 2020 р. / НАПН України, Ін-т педагогіки НАПН України ; за заг. ред. О. І. Локшиної. Київ ; Біла Церква : Авторитет, 2020. С. 35-52. URL: https://lib.iitta.gov.ua/721237/.

100. Часнікова О. В. Випробування часом: від концепції до реальної практики навчання географії в дистанційному вимірі. Географія та економіка в школі. 2020 р. №6-C. 8-14. URL : https://bit.ly/3qoGTkX.

101. Щодо методичних рекомендацій про викладання навчальних предметів у закладах загальної середньої освіти у 2020/2021 навчальному році: Лист Міністерства освіти і науки України України від 11.08.2020 р. №1/9-430. URL : https://bit.ly/35Mg94E.

102. Щодо оплати праці працівників закладів освіти під час призупинення навчання через карантин: лист Міністерства освіти і науки України від 13.03.2020 р. №1/9-161. URL : https://mon.gov.ua/storage/app/media/13.03.2020/1_9-161.pdf. 
103. Щодо організації дистанційного навчання. Лист Міністерства освіти і науки України №1/9-609 від 2 листопада 2020 року. URL: https://mon.gov.ua/ ua/npa/shodo-organizaciyi-distancijnogo-navchannya.

104. Щодо організації освітнього процесу в закладах загальної середньої освіти під час карантину: лист Міністерства освіти і науки України від 23 березн. 2020 р. №1/9-173. URL : https://mon.gov.ua/ua/npa/shodo-organizaciyiosvitnogo-procesu-v-zakladah-zagalnoyi-serednoyi-osviti-pid-chas-karantinu.

105. Щодо проведення підсумкового оцінювання та організованого завершення 2019-2020 навчального року: лист Міністерства освіти і науки України від 16.04.2020 р. № 1/9-213. URL: https://bit.ly/3wCtTKM.

106. Яценко Т. О., Міщенко О. В. Шкільне дистанційне навчання літератури: від можливості до необхідності. Українська мова і література в школі. 2020. №4. C. 20-29. URL : http://lib.iitta.gov.ua/721562/.

107. Яценко Т. О., Тригуб І. А. Дистанційне навчання у шкільному курсі української літератури. Комп'ютер у школі та сім'ї. 2020. №3. URL : http://lib.iitta. gov.ua/722793/.

108. Awarding qualifications in summer 2021. Guidance. gov.uk : website. Updated 20 April 2021. URL: https://www.gov.uk/government/publications/awardingqualifications-in-summer-2021/awarding-qualifications-in-summer-2021.

109. COVID-19 and human development: Assessing the crisis, envisioning the recovery. 2020 Human Development Perspectives. United Nations Development Programme (UNDP). New York: UNDP, 2020. URL : http://hdr.undp.org/en/ hdp-covid.

110. COVID-19 Educational Disruption and Response. (2020) (n.d.). General format. Available at: https://en.unesco.org/covid19/educationresponse; 2. Crisissensitive educational planning. In: UNESCO COVID-19. Education Response. Education Sector issue notes, Issue noten №2.4 - April 2020. URL : https:// unesdoc.unesco.org/ark:/48223/pf0000373272.

111. D`Angelo, Guiseppe From Didacticsto e-Didactics / Guiseppe D`Angelo. Napoli: Liguori, 2007. - 411p. URL : http://www.liguori.it/download/ volume/4065/4065.pdf.

112. Diagnosticējošie darbi 3. un 6. klasē (2020./2021.m.g.). Valsts izglītības satura centrs : website. URL: https://bit.ly/3vviFqa.

113. Education Responses to COVID-19: Embracing Digital Learning and Online Collaboration. URL : https://bit.ly/3qiu7V8.

114. Education: From disruption to recovery. UNESCO online. URL : https://en.unesco. org/covid19/educationresponse.

115. Eksāmeni 9.klases skolēniem ir atcelti. Mācību gads noslēgsies ar vērtējumu gadā. Valsts izglītības satura centrs : website. URL: https://bit.ly/3cljxkM.

116. European Commission. Educational inequalities in Europe and physical school closures during Covid-19. URL : https://ec.europa.eu/jrc/sites/jrcsh/files/ fairness_pb2020_wave04_covid_education_jrc_i1_19jun2020.pdf. 
117. Fleischmann: Computer didaktik. Proseminar arbeit am Institut für Pädagogik der Technischen Universität Darmstadt. Betreuerin: Bärbel Könekamp. Darmstadt 1999.

118. Izmainas valsts pārbaudes darbu norisē. Valsts izglïtības satura centrs : website. URL: https://bit.ly/3xkwPvC.

119. Lege privind anularea examenelor naționale de absolvire a programelor de studii în învățămîntul general, sesiunea de examene 2020. Chișinău, 21 mai 2020. № 71. Parlamentul Republicii Moldova : site oficial. URL: http://www.parliament. md/ProcesulLegislativ/Proiectedeactelegislative/tabid/61/Legislativld/5039/ language/ro-RO/Default.aspx.

120. Newton, Derek (2020). Most Teachers Say They Are 'Not Prepared' To Teach Online. URL : https://bit.ly/3d7K62Z.

121. Olga V. această petiție. Publicat 28 februarie 2021. (Actualizare 5 martie 2021). Avaaz.org : site oficial. URL: https://bit.ly/35n5YDg.

122. Policy brief: education during COVID-19 and beyond. URL : https://www. un.org/development/desa/dspd/wp-content/uploads/sites/\%2022/2020/08/ sg_policy_brief_covid-19_and_education_august_2020.pdf»https://www. un.org/development/desa/dspd/wp-content/uploads/sites/22/2020/08/ sg_policy_brief_covid-19_and_education_august_2020.pdf.

123. QAA (2020). Building a Taxonomy for Digital Learning. URL: https://www.qaa.ac.uk/ newsevents/news/qaa-publishes-building-a-taxonomy-for-digital-learning.

124. UNESCO (n.d.). Distance learning solutions. URL : https://en.unesco.org/ covid19/educationresponse/solutions.

125. UNESCO Thesaurus. (2020). Distance education. URL : http://vocabularies. unesco.org/browser/thesaurus/en/page/concept8237.

126. UNESCO. (2021). One year into COVID, UNESCO convenes global meeting of education ministers to ensure learning continuity. URL : https://en.unesco.org/ news/one-year-covid-unesco-convenes-global-meeting-education-ministersensure-learning-continuity.

127. UNESCO. 2020. Global Education Monitoring Report 2020: Inclusion and education: All means all. Paris, UNESCO, 2020. URL : https://unesdoc.unesco. org/ark:/48223/pf0000373718.

128. UNESCO. National learning platforms and tools. URL : https://en.unesco.org/ covid19/educationresponse/nationalresponses.

129. UNESCO-UNICEF-World Bank Survey on National Education Responses to COVID-19 School Closures, May-June 2020. URL : https://bit.ly/3zAew7N.

130. UNICEF. How involved are parents in their children's learning? MICS6 data reveal critical insights. URL : https://uni.cf/3vx6jhn. 


\title{
ДИСТАНЦІЙНЕ НАВЧАННЯ В УМОВАХ КАРАНТИНУ: ДОСВІД ТА ПЕРСПЕКТИВИ
}

\author{
Аналітико-метоgичні матеріали \\ За загальною редакцією дійсного члена НАПн України, \\ д.пед.н., проф. О.М. Топузова.
}

\section{Авторський колектив:}

Н.І. Богданець-Білоскаленко (4.1.3), Н.В. Бондаренко (4.1.1), М.І. Бурда (4.4), Д.В. Васильєва (4.4.), Л.П. Величко (4.3.1), С.Г. Головко (6.1), О.В. Голота (1.3), О.М. Горошкіна (4.1.1), Т.М. Засєкіна, В.Р. Ільченко (1.3), О.Г. Козленко (4.3.1), Т.В. Коршевнюк (4.3.1), І.П. Крячко (4.3.2), О.І. Локшина (р. 2), Т.О. Лукіна (5.1, 5.3), О.В. Малихін (1.1), Т.Г. Назаренко (4.4), С.О. Науменко (5.2), О.С. Нетрибійчук(4.3.1), В.І. Новосьолова (4.1.1), О.М. Онаць (6.2), О.В. Онопрієнко (р. 3), Т.К. Полонська (4.1.4), О.І. Пометун (4.2.), Л.О. Попова (4.1.1), В.Г. Редько (4.1.4), Т.О. Ремех (4.2), В.В. Сіпій (4.3.2), С.Е. Трубачева (1.2), В.І. Туташинський (4.5), О.Л. Фідкевич (4.1.3), О.М. Шпарик (р.2), Т.О. Яценко (4.1.2).

Упорядник - М. В. Головко.

Обкладинка - Л. П. Лук'яненко

Комп'ютерна верстка - А. П. Коломієць

Підписано до друку 07.07.2021 р. Формат 60х84 1/16

Гарнітура Calibri. Друк офсетний.

Папір офсетний. Ум. друк. арк 11,16

Наклад 300 пр.

\section{Видавництво «Педагогічна думка»}

04053, м. Київ, вул. Січових Стрільців, 52-а, корп. 2;

тел./факс: (044) 481-38-85

book-xl@ukr.net

Свідоцтво про внесення суб'єкта видавничої справидо

Державного реєстру видавців, виготовників розповсюджувачів видавничої продукції

Серія ДК №3563 від 28.08. 2009 р. 